UNIVERSIDADE DE SÃO PAULO
PROGRAMA DE PÓS-GRADUAÇÃO INTERUNIDADES EM MUSEOLOGIA

Monica lafrate

Dos Salões de Arte Contemporânea à Pinacoteca Municipal de São Caetano do Sul: os caminhos e descaminhos de uma coleção de arte (1967 a 2002)

São Paulo 
Monica lafrate

Dos Salões de Arte Contemporânea à Pinacoteca Municipal de São Caetano do Sul: os caminhos e descaminhos de uma coleção de arte (1967 a 2002)

Dissertação apresentada ao Programa de PósGraduação Interunidades em Museologia da Universidade de São Paulo para obtenção do título de Mestre em Museologia.

Área de Concentração: Museologia

Orientadora: Prof. ${ }^{\text {a }}$ Dr. ${ }^{\text {a }}$ Ana Gonçalves Magalhães

Linha de Pesquisa: História dos Processos

Museológicos, coleções e acervos

Versão corrigida $\left(^{*}\right)$

$\left(^{*}\right)$ A versão original encontra-se disponível no MAE/USP

São Paulo 
Autorizo a reprodução e divulgação integral ou parcial deste trabalho, por qualquer meio convencional ou eletrônico, para fins de estudo e pesquisa, desde que citada a fonte.

Ficha catalográfica elaborada pelo Serviço de Biblioteca e Documentação, MAE/USP, com os dados fornecidos pelo(a) autor(a)

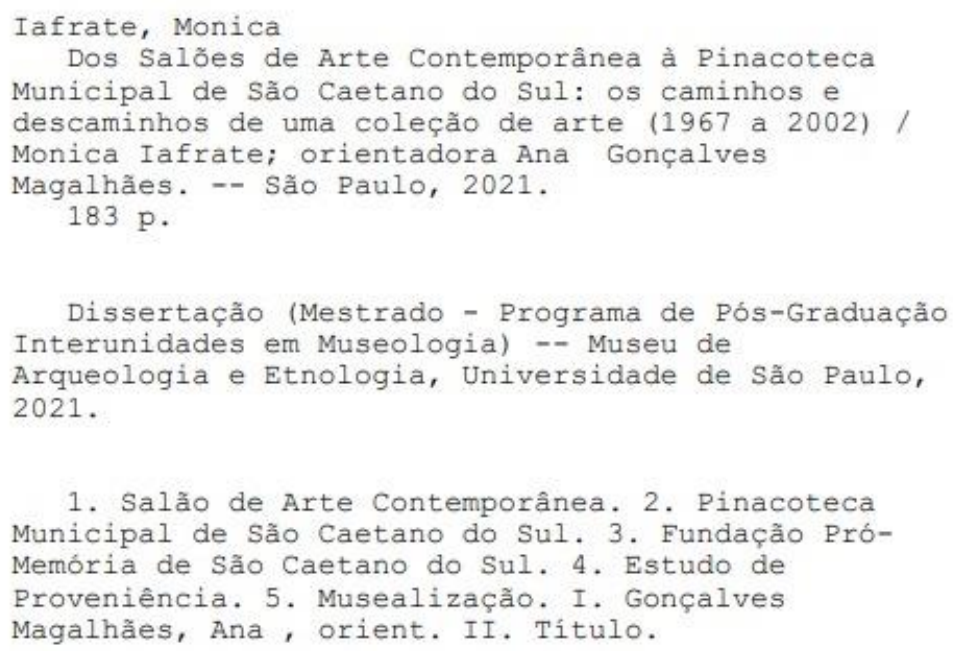

1. Salão de Arte Contemporânea. 2. Pinacoteca Municipal de São Caetano do Sul. 3. Fundação PróMemória de São Caetano do Sul. 4. Estudo de Proveniência. 5. Musealização. I. Gonçalves Magalhães, Ana, orient. II. Titulo. 


\section{FOLHA DE APRESENTAÇÃO}

Nome: IAFRATE, Monica

Título: Dos Salões de Arte Contemporânea à Pinacoteca Municipal de São Caetano do Sul: os caminhos e descaminhos de uma coleção de arte (1967 a 2002)

Dissertação apresentada ao Programa de Pós-Graduação Interunidades em Museologia da Universidade de São Paulo para obtenção do título de Mestre em Museologia.

Aprovado em:

\section{Banca Examinadora}

Prof. ${ }^{a}$ Dr. ${ }^{a}$ Ana Gonçalves Magalhães

Instituição: Museu de Arte Contemporânea - Universidade de São Paulo.

Prof. ${ }^{\text {a }}$ Dr. ${ }^{a}$ Ana Paula Cavalcanti Simioni

Instituição: Instituto de Estudos Brasileiros - Universidade de São Paulo.

Prof. ${ }^{\text {D }}$ Dr. ${ }^{\text {a }}$ Marilúcia Bottallo

Instituição: Centro Universitário Belas Artes de São Paulo. 
Para minha família Marcello (in memoriam), Geni e Marcia, bases de tudo.

Em memória de Milton Andrade e Oscar Garbelotto, que moveram as rodas da História 


\section{AGRADECIMENTOS}

Quero agradecer à minha orientadora, Prof. ${ }^{a}$ Dr. ${ }^{a}$ Ana Gonçalves Magalhães por suas contribuições e sugestões sempre certeiras. Sem a sua confiança, apoio e generosidade, nada seria possível.

A meu caro amigo Prof. Dr. Camilo Mello Vasconcellos, por me convencer a aceitar este desafio.

A minha banca de qualificação, Marilúcia Bottallo e Paulo Garcez, pela leitura generosa e sugestões enriquecedoras.

A Cristina Bruno, que, por tantos caminhos que trilhamos, ensinou-me a amar a Museologia.

A meu querido Júlio Abe Wakahara, gratidão eterna pelo aprendizado e amizade sincera. Saudades.

Aos meus companheiros do PPGMUS 2018, em especial à Josy, André, Helen e Camila Romano pela paciência infinita para com minhas dúvidas.

Aos funcionários das bibliotecas do Museu de Arqueologia e Etnologia e do Museu de Arte Contemporânea da Universidade de São Paulo, pelo atendimento atencioso e eficiente.

Aos meus companheiros da Comissão Técnica das Instituições Oficiais de Memória do Grande ABC Jorge, Malu, Mayra, Cecília, Paulo e Suzana, pelas histórias e experiências compartilhadas.

A José Armando Pereira da Silva, Enock Sacramento e Aleksandar Jovanovic, pelas memórias compartilhadas.

A Sonia Maria Franco Xavier, Neusa Schilaro Scaléa e André Caram, pelos desafios compartilhados na abertura da Pinacoteca Municipal.

Aos meus colegas de trabalho da Fundação Pró-Memória de São Caetano do Sul, em especial Márcia Gallo, Fabiana Cavalcante, Nair Duarte, Jacqueline Nakagawa, Cristina Toledo, Paula Fiorotti, Roberta Giotto, Rodrigo Marzano, Jô Cajaíba, Jussara Muniz, Antônia Orcajo, Reginaldo Canhoni, João Alberto Tessarini e ao nosso presidente, Charly Farid Cury, pelo apoio e confiança fundamentais.

E por último, mas não menos importante, a minha família, minha mãe e irmã, que suportaram minhas ausências e me ajudaram em tudo para que eu realizasse um sonho a tanto tempo adiado. 
Toda arte é uma confissão de que a vida não basta Fernando Pessoa 


\section{RESUMO}

IAFRATE, Monica. Dos Salões de Arte Contemporânea à Pinacoteca Municipal de São Caetano do Sul: os caminhos e descaminhos de uma coleção de arte (1967 a 2002). 183f. Dissertação (Mestrado), Programa de Pós-Graduação Interunidades em Museologia da Universidade de São Paulo, 2021.

A presente dissertação tem como objetivo estudar a coleção de obras de arte reunidas através da realização dos Salões de Arte Contemporânea de São Caetano do Sul, levados a cabo entre 1967 e 1988. O conjunto que compõe o núcleo inicial do acervo da Pinacoteca Municipal da Fundação Pró-Memória de São Caetano do Sul. Este estudo se baseou em duas linhas teóricas, que versam sobre os Estudos de proveniência e os processos de musealização da arte contemporânea. Através dele foi possível vislumbrar os caminhos da política cultural que instituiu os salões de arte no município analisado, e as razões da opção pela arte contemporânea de então, um movimento vanguardista que correspondia à identidade que se estava a construir para a cidade. Na segunda parte do trabalho, problematizamos a musealização da arte contemporânea, considerando os aspectos impostos pela materialidade e pela poética contemporâneas, já que estas afetam a conservação e a preservação das obras. Também através da análise dos salões realizados conseguimos reconstituir a coleção que teria sido formada pelos prêmios-aquisição e compará-la ao acervo que "sobreviveu", além de tratarmos do hiato formado entre a realização do último Salão de Arte Contemporânea (1988) e a inauguração da Pinacoteca Municipal (2002).

Palavras-chave: Salão de Arte Contemporânea; Pinacoteca Municipal de São Caetano do Sul; Fundação Pró-Memória de São Caetano do Sul; Estudo de Proveniência; Musealização. 


\begin{abstract}
IAFRATE, Monica. From the Contemporary Art Salons to the Municipal Pinacoteca of São Caetano do Sul: the paths and deviations of an art collection (1967 a 2002). 183f. Dissertation (Master degree), Programa de Pós-Graduação Interunidades em Museologia da Universidade de São Paulo, 2021.

This dissertation aims to study the collection of works of art gathered through the realization of the Contemporary Art Salons of São Caetano do Sul, carried out between 1967 and 1988. The set that forms the initial core of the Foundation's Municipal Pinacoteca collection Pró-Memória de São Caetano do Sul. This study was based on two theoretical lines which deal with the provenance reserach and the musealization processes of contemporary art. Through it, it was possible to glimpse the paths of the cultural policies that instituted the art salons in the analyzed city, and the reasons for opting for contemporary art at the time, an avant-garde movement that corresponded to the identity that was being built for the city. In the second part of the study, we discuss the musealization of contemporary art, considering the aspects imposed by contemporary materiality and poetics, as these affect the conservation and preservation of the works. Also through the analysis of the exhibitions, we were able to reconstitute the collection that would have been formed by the prêmios-aquisição and compare it to the collection that "survived", as well as dealing with the gap formed between the last Contemporary Art Salon (1988) and the inauguration of the Municipal Pinacoteca (2002).
\end{abstract}

Keywords: Contemporary Art Salon; Municipal Pinacoteca of São Caetano do Sul; São Caetano do Sul Pro-Memory Foundation; Provenance Research; Musealization. 


\section{LISTA DE ILUSTRAÇÕES}

Figura 1 - Rua Amazonas entre os bairros Santo Antônio e Santa Paula, década de 1940. Acervo Fundação Pró-Memória de São Caetano do Sul

Figura 2 - Membros da Società di Mutuo Soccorso Principe di Napoli em frente à sua sede na Rua Perrella Bairro Fundação, 1927. Acervo Fundação Pró-Memória de São Caetano do Sul

Figuras 3, 4 e 5 - Algumas ações desenvolvidas pela Associação Cultural e Artística de São Caetano do Sul, em 1964. ACASCS Jornal. Acervo Fundação PróMemória de São Caetano do Sul

Figuras 6, 7 e 8 - Paço Municipal e Concha Acústica - projeto Zenon Lotufo, 1961. Acervo Fundação Pró-Memória de São Caetano do Sul

Figura 9 - Entrada da cidade, final da década de 1960. Acervo Fundação PróMemória de São Caetano do Sul

Figura 10 - Milton Andrade, Oscar Garbelotto e Mário Dall'Mas, década de 1960. Acervo Fundação Pró-Memória de São Caetano do Sul

Figura 11 - Aluísio Domingos dos Santos com sua obra Mãe Preta, década de 1960. Acervo Fundação Pró-Memória de São Caetano do Sul

Figura 12 - Sinval Correia Soares em seu ateliê, década de 1960. Acervo Fundação Pró-Memória de São Caetano do Sul

Figura 13 - Etiquetas coladas no verso da obra Quadro I de Niobe Xandó, premiada no I Salão de Arte Contemporânea, 1967

Figura 14 - Complexo Educacional do Ensino Fundamental, sede da Fundação PróMemória e da Pinacoteca Municipal, 2002. Acervo Fundação Pró-Memória de São Caetano do Sul

Figuras 15 e 16 - Exposição inaugural da Pinacoteca Municipal - Retrospectiva 2002 - onze anos de Salões de Arte, 2002 Acervo Fundação Pró-Memória de São Caetano do Sul

Figura 17 e 18 - Folder da exposição do Grupo Vanguarda em Santo André, 1963 Acervo Enock Sacramento 
Figura 19 - Obra Superfície para vermelhos de Geraldo de Souza, que participou da mostra do Grupo Vanguarda em Santo André. Acervo Enock Sacramento

Figuras de 20 a 26 - Cartazes dos Salões de Arte Contemporânea. Acervo Fundação Pró-Memória de São Caetano do Sul

Figura 27 - Inauguração de um dos primeiro Salões de Arte Contemporânea. Em primeiro plano, os vereadores Sebastião Lauriano dos Santos e Fábio Ventura, o jornalista Humberto Pastore e Aluísio Domingos dos Santos, final da década de 1960. Acervo Fundação Pró-Memória de São Caetano do Sul

Figura 28 - Gabinete do Prefeito Hermógenes Walter Braido (terceiro da esquerda para a direita). O fundo, parte do tríptico Construção de Regis Machado da Silva, década de 1970. Acervo Fundação Pró-Memória de São Caetano do Sul

Figura 29 - Gabinete do Prefeito Raimundo da Cunha Leite (primeiro da esquerda para a direita). O fundo, a obra Genesis de Bandarra, final da década de 1970.

Acervo Fundação Pró-Memória de São Caetano do Sul

Figura 30 - Obra de Fábio Magalhães, participante do IX Salão de Arte Contemporânea. Diário do Grande ABC, 18 jun. 1976

Figura 31 - Happening de Ivald Granato na abertuta do IX Salão de Arte Contemporânea. Diário do Grande ABC, 01 ago. 1976

Figura 32 e 33 - Obras "perdidas" do IX Salão de Arte Contemporânea

Diário do Grande ABC, 01 ago. 1976 


\section{LISTA DE SIGLAS}

A.I.A.P. Associação Internacional de Artistas Plásticos

ABCA Associação Brasileira de Críticos de Arte

ACASCS Associação Cultural e Artística de São Caetano do Sul

AIB Ação Integralista Brasileira

APBA Associação Paulista de Belas Artes

ASBA Associação Sambernardense de Belas Artes

CIESP Centro das Indústrias do Estado de São Paulo

COPI Cursos de Orientação Prático-Industrial

DEPEC Departamento de Educação e Cultura

FNPM Fundação Nacional Pró-Memória

G.E.I.A. Grupo Executivo da Indústria Automobilística

GIPEM Grupo Independente de Pesquisadores da Memória do Grande ABC

IAB Instituto dos Arquitetos do Brasil

IBPI Associação Brasileira de Desenho Industrial

IMES Instituto Municipal de Ensino Superior

MAC USP Museu de Arte Contemporânea da Universidade de São Paulo

MACC Museu de Arte Contemporânea de Campinas

MoMA Museum of Modern Art

OND Opera Nazionale Dopolavoro

PAGE Plano de Ação do Governo do Estado

SACC Salão de Arte Contemporânea de Campinas

SBASA Sociedade de Belas Artes de Santo André

SESI Serviço Social da Indústria

TUC Teatro Universitário de Campinas

USCS Universidade de São Caetano do Sul 


\section{SUMÁRIO}

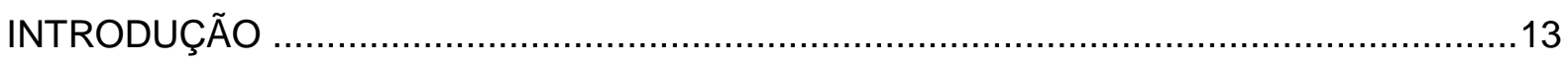

CAPÍTULO 1 - REFAZENDO CAMINHOS: AS ORIGENS DA COLEÇÃO .........................23

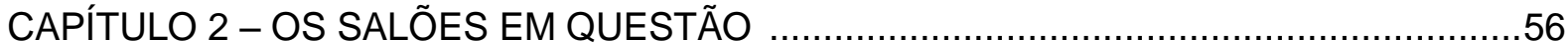

2.1. Comissões Executivas / Organizadoras ………………....................................65

2.2. Comissão de Seleção e Julgamento ..................................................................65

2.3. Formato dos Salões de São Caetano ………………………………………....66

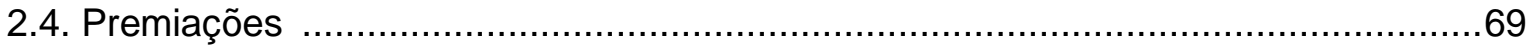

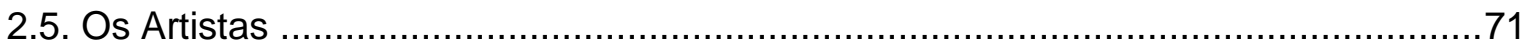

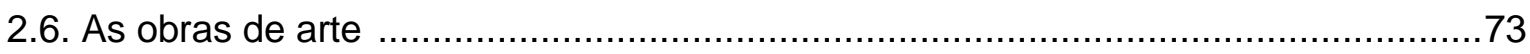

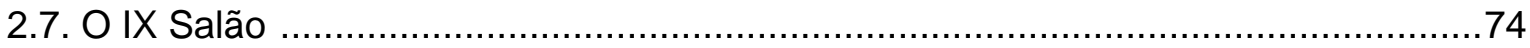

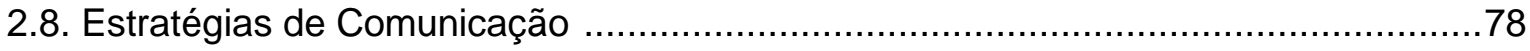

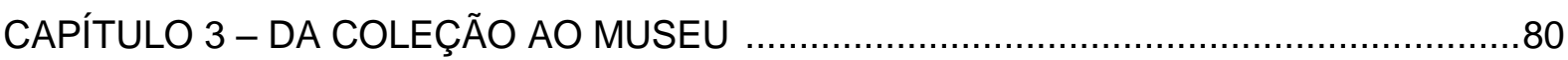

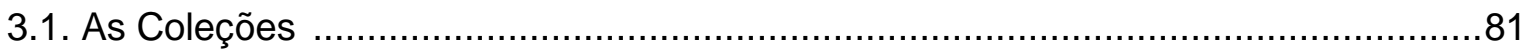

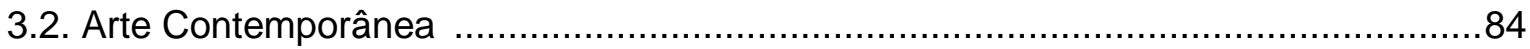

3.3. Colecionando Arte Contemporânea ………………………………………….....

3.4. Arte Contemporânea e Museus …………………………………………….......92

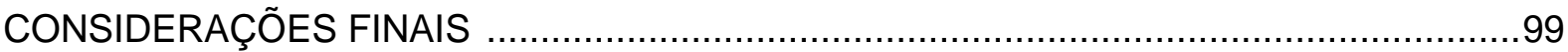

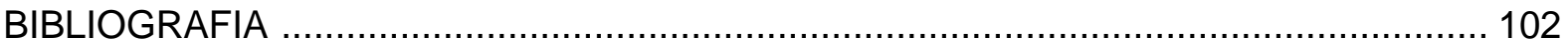

ANEXOS 


\title{
INTRODUÇÃO
}

\begin{abstract}
Compreender (o que aqui significa constituir) um acervo de arte contemporânea é igualmente expor a trajetória de políticas institucionais e artísticas de uma arte em constante mutação e potencialmente polêmica.
\end{abstract}

(Emerson Dionísio G.de Oliveira)

A motivação para o desenvolvimento desta dissertação nasceu do contato que tivemos com a coleção de obras de arte contemporânea que se encontrava sob os cuidados na Fundação Pró-Memória de São Caetano do Sul, durante a preparação da exposição inaugural da Pinacoteca Municipal, em setembro de $2001{ }^{1}$ As poucas informações conhecidas naquele momento indicavam que essas obras haviam sido adquiridas por meio de prêmios-aquisição durante a realização de salões de arte contemporânea realizados pela municipalidade entre os anos 1967 e 1988. Além de uma relação com os nomes dos artistas, os títulos e datas das obras, muito pouco era de conhecimento do corpo técnico da instituição.

Uma vez criada, a Pinacoteca Municipal seguiu sua missão institucional ${ }^{2}$, mas, apesar de fortemente influenciada pela natureza do seu acervo inicial, os conhecimentos sobre ele não foram aprofundados ao longo do tempo. Como profissionais responsáveis por tal acervo, muitas vezes sentimos que essa situação se, por um lado, não causava impedimento à sua difusão e preservação, por outro empobrecia o potencial de sentidos, significados e conexões que essas obras poderiam suscitar, limitando também as ações museológicas desenvolvidas.

Isso fica evidente quando se analisa em retrospecto as exposições realizadas nestes vinte anos de existência da Pinacoteca Municipal. Depois da grande exposição inaugural, onde cerca de cinquenta por cento da coleção foi

\footnotetext{
${ }^{1}$ A Fundação Pró-Memória de São Caetano do Sul é uma autarquia municipal, cujo principal objetivo é preservar e divulgar a memória e a histórica locais e que agrega em sua estrutura o Museu Histórico Municipal, o Centro de Documentação Histórica e a Pinacoteca Municipal, tendo sido esta última inaugurada em abril de 2002.

2 "Enquanto espaço de produção e difusão culturais, os objetivos da Pinacoteca são bem claros e definidos: preservar, manter e exibir obras de arte, e também formar públicos apreciadores e críticos." Disponível em http://www.fpm.org.br/Sobre/Pinacoteca/1. Acesso em 16 jun. 2020.
} 
exposta, o programa expositivo da instituição tem privilegiado as exposições temporárias de artistas contemporâneos, mas as obras do acervo têm participado pontualmente de algumas exposições, como no caso do programa Diálogos ${ }^{3}$.

Da inquietação causada por essa situação derivaram as questões que se tornaram os objetivos principais de nossa pesquisa. O primeiro objetivo foi compreender o contexto em que essa coleção de obras de arte contemporânea foi reunida, entendendo-se aqui a palavra "contexto" da forma mais ampla possível, abrangendo aspectos sociais, políticos e culturais, desde a criação dos salões de arte contemporânea, na década de 1960, até a criação da Pinacoteca Municipal e sua inserção na Fundação Pró-Memória de São Caetano do Sul.

Um ponto importante desta análise é procurar entender as razões que levaram à escolha de se realizar um salão de arte contemporânea em uma cidade localizada no subúrbio de São Paulo, fora do protagonismo dos grandes centros (MARTINS, 1992), e, sobretudo, entender em que momento buscou-se essa posição de vanguarda, uma vez que as mostras e salões até então realizados na cidade e na região se identificavam com as artes decorativas ou, no máximo, com a arte moderna. Neste sentido, São Caetano do Sul foi precursora de uma tendência que se espalhou pelas demais cidades da região ${ }^{4}$, assumindo o papel de um "centro excêntrico" ${ }^{5}$, fenômeno identificado por Aracy Amaral, apesar de sua proximidade da capital paulista.

O segundo objetivo proposto foi compreender a formação da coleção dos Salões de Arte Contemporânea em si, através da reconstituição de sua trajetória, com sua organização, regulamentos, comissões julgadoras e premiações, consolidando, assim, um conhecimento mais profundo sobre a coleção e recuperando informações sobre as obras que, embora tenham sido adquiridas

\footnotetext{
${ }^{3}$ O programa de mostras Diálogos - O artista e sua obra e o artista e seu tempo tem como objetivo buscar contato com artistas que tinham obras no acervo e convidá-los para expor uma pequena compilação da sua produção posterior à sua participação nos salões de arte. Um ponto importante era que depois da mostra o artista se comprometia a fazer uma nova doação para o acervo da Pinacoteca Municipal_(IAFRATE; TESSARINI, 2012).

${ }^{4}$ No ano seguinte à realização do primeiro Salão de Arte Contemporânea em São Caetano do Sul, a cidade Santo André transformou o seu Salão de Artes Plásticas em Salão de Arte Contemporânea, o qual continua a ser realizado até os dias atuais. Em São Bernardo do Campo, a Associação Sambernardense de Artes (ASBA) realizou alguns salões nas décadas de 1950 e 1970. O 1ํ Salão de Artes Plásticas promovido pela Prefeitura Municipal dessa cidade foi realizado em 1991. (NEGRESOLLI, 2016)

5 "O dado importante é notar que neste fenômeno do surgimento de centros ex-cêntricos em várias partes do Brasil, depois da criação de Brasília, é que seus artistas não se sentem mais compelidos a viver no Rio de Janeiro, nem forçosamente buscam São Paulo." (AMARAL 2006a: 91)
} 
através do prêmio-aquisição, tiveram um destino ignorado, bem como sobre aquelas que não foram premiadas, e portanto, não foram adquiridas e se encontram no acervo.

Por fim, o terceiro objetivo decorre dos anteriores, mas não é, por isso, menos relevante. O olhar sobre o acervo e o museu que ele originou nos suscitou algumas reflexões sobre a musealização da arte contemporânea e o colecionismo público de arte. Sem ter a pretensão de esgotar tais temas, vamos abordar o papel da institucionalização museal na preservação e divulgação de coleções, levando em conta as peculiaridades da arte contemporânea. Queremos também contribuir para a reflexão da formação de acervos públicos a partir do caso analisado. No desenvolvimento dessa proposição, há um ponto que demandou certo enquadramento, por ser o nosso objeto de estudo uma coleção de obras de arte contemporânea. Temos que concordar aqui com Emerson Dionísio de Oliveira, que em sua obra Museus de Fora, define seu objeto de estudo “(...) não tomo como certo que haja uma definição - por mais e múltipla que qualquer uma delas ambicione ser - do que venha a ser a Arte Contemporânea." (OLIVEIRA, 2010, p. 16). No nosso caso, procuramos identificar o "lugar" e a "data" do acervo aqui estudado dentro ao grande cenário da arte contemporânea.

Visando a esses objetivos, trabalhamos sobre duas bases teóricas: os estudos de proveniência e a teoria museológica, sobretudo as reflexões sobre a musealidade e o processo de musealização, discussões estabelecidas por autores como Zbyněk Stránský (apud BRULON, 2017), André Desvallées e François Mairesse (2014), Waldisa Rússio (2010) e Cristina Bruno (1998). Dessa forma, levamos em conta o caráter interdisciplinar da Museologia, associando a narrativa histórica às análises baseadas na teoria museológica, notadamente àquelas que tocam a musealização da arte contemporânea.

O nosso estudo de caso diz respeito a uma realidade comum a muitos museus, quer sejam eles grandes ou pequenos: contar em seus acervos com coleções ou obras de cujas proveniências pouco se sabe. O termo proveniência significa lugar de onde algo provém, origem, procedência. No entanto, tratando-se de acervos históricos, artísticos ou documentais, esse termo pode ganhar um sentido mais amplo, abarcando não somente os dados essenciais sobre propriedade, mas também sua trajetória até sua incorporação ao acervo. Para a 
Arquivologia, por exemplo, o princípio da proveniência ${ }^{6}$ é uma chave, sobre o qual se organiza toda a teoria e prática desse campo de conhecimento. Para a museologia, embora o termo "proveniência" não tenha o mesmo peso conceitual, ele abrange informações importantes no processo de musealização, quer sejam objetos ou obras de arte.

Porém, esses são os dados mais difíceis de acessar. No processo de catalogação das coleções dos museus brasileiros, as informações sobre a proveniência dos itens que perfazem seus acervos geralmente estão dispersas em diferentes campos nas fichas catalográficas denominados como "histórico", "doação" ou "referências biográficas", por exemplo. E, notadamente, estes são os campos que menos informações contêm.

Questões como essas têm sido objeto de um campo de pesquisa ainda incipiente em nosso País, mas que já estabeleceu certa tradição na Europa e nos Estados Unidos. Tratam-se dos estudos de proveniência ou provenance research com são chamados na literatura inglesa. Tal linha de pesquisa foi impulsionada principalmente por investigações acerca do patrimônio cultural e artístico indevidamente confiscado pelas forças nazistas no período da Segunda Grande Guerra na Europa e acabaram em mãos de colecionadores e acervos de museus.

Estudos de proveniência não são recentes: se considerarmos o
desenvolvimento das práticas de colecionismo, especialmente na era
moderna, a ideia de que alguém tenha possuído uma obra de arte e deixado
nela sua marca, por exemplo, muito contribuiu para que historiadores da
arte compreendessem a formação de coleções e acervos de museus, bem
como pudessem investigar a história da recepção e circulação dos objetos,
como operavam circuitos e mercados de arte em determinados contextos,
assim levantando questões importantes sobre a construção mesma da
narrativa da arte para nós. (MAGALHÃES, 2016 p. 39)

Se esse tipo de estudo não é uma novidade no campo de estudo da História da Arte, ele vem ganhando uma abrangência maior, que pode ser aplicada em outros campos de conhecimento, como a nossa proposta de trabalho, como assinalam Feigenbaum e Reist.

[...] expandimos nosso escopo para além da definição restrita do termo proveniência, que atende apenas aos fatos de propriedade e transferência, para explorar ideias e narrativas sobre as origens e itinerários de objetos, considerar os usos históricos das informações de proveniência, e chamar a atenção para o poder transformador da propriedade. Em relação ao último desses pontos, os ensaios deste volume demonstram de inúmeras

${ }^{6}$ Princípio básico da arquivologia segundo o qual o arquivo produzido por uma entidade coletiva, pessoa ou família não deve ser misturado aos de outras entidades produtoras. Também chamado princípio do respeito aos fundos. (DICIONÁRIO, 2005) 
maneiras como o relacionamento de um proprietário com uma obra de arte, em graus variados, com os proprietários anteriores da obra, pode mudar irrevogavelmente a maneira como o trabalho será percebido e entendido pelas gerações futuras. (FEIGENBAUM; REIST, 2012, p. 1, tradução nossa)

Inspirados pela potencialidade desse campo de estudos, voltamos nossa atenção para a coleção fundadora da Pinacoteca Municipal de São Caetano, vislumbrando ali uma história nunca registrada, interessando-nos, sobretudo, além de retraçar o percurso histórico desta coleção, compreender como se deu o seu processo de musealização.

Acreditamos que, lançar luz sobre esses pontos e registrar tal percurso histórico é importante para a afirmação e consolidação da Pinacoteca Municipal e para a própria Fundação Pró-Memória de São Caetano do Sul, tanto em suas bases atuais, como, também, para subsidiar as futuras gestões, sempre sujeitas a mudanças devido à dinâmica da administração municipal.

Do ponto de vista do campo de conhecimento museológico, a musealização é o processo no qual um objeto, obra de arte ou espécime da natureza, quer seja por seus valores intrínsecos ou por outros valores que lhe sejam atribuídos, são retirados de seu meio de origem e submetidos a um novo regime de preservação e comunicação, recebendo assim o estatuto de objeto de museu ou musealia. ${ }^{8}$ Segundo Desvallés e Mairesse,

\begin{abstract}
O processo de musealização não consiste meramente na transferência de um objeto para os limites físicos de um museu, como explica Zbyněk Stránský [1995]. Um objeto de museu não é somente um objeto em um museu. Por meio da mudança de contexto e do processo de seleção, de "thesaurização" e de apresentação, opera-se uma mudança do estatuto do objeto. Seja este um objeto de culto, um objeto utilitário ou de deleite, animal ou vegetal, ou mesmo algo que não seja claramente concebido como objeto, uma vez dentro do museu, assume o papel de evidência material ou imaterial do homem e do seu meio, e uma fonte de estudo e de exibição, adquirindo, assim, uma realidade cultural específica. (DESVALLEÉS; MAIRESSE, 2014, p. 57)
\end{abstract}

\footnotetext{
${ }^{7}$ No original: "In this volume, however, we expand our scope beyond the narrow definition of the term provenance, which attends only to the facts of ownership and transfer, to explore ideas and narratives about the origins and itineraries of objects, consider the historical uses of provenance information, and draw attention to the transformative power of ownership. Regarding the last of these points, the essays in this volume demonstrate in myriad ways how the relationship of na owner with a work of art ar, in varying degrees, with the work's previous owners, may change irrevocably the way that work will be perceived and understood by future generations." (FEIGENBAUM; REIST, 2012, p. 1).

${ }^{8}$ Os conceitos de musealia, musealidade e musealização foram desenvolvidos por Zbyněk Stránský. O primeiro termo se refere aos objetos de museu; o conceito de musealidade foi entendido por ele como sendo um valor documental específico da musealia e a musealização, como sendo o processo de aquisição dessa qualidade museal. (Brulon, 2017).
} 
Ainda segundo Stránský, a musealização é a "aquisição da qualidade museal", ou seja, "uma expressão da tendência humana universal de preservar, contra a mudança e a degradação natural, os elementos da realidade objetiva que representam valores culturais que o homem, como ser cultural, precisa preservar em seu próprio interesse", ressaltando, no entanto, que "é somente por meio de métodos específicos da museologia que é possível descobrir aquilo que faz de um objeto comum um objeto de museu". (STRÁNSKÝ apud BRULON, 2017, p. 412 e 413).

Também é importante ressaltar que, diferentemente como muitas vezes se supõe, a musealização não se restringe à comunicação museológica. Segundo Waldisa Rússio (2010a, p. 125), a musealização se baseia na valorização de certos objetos e "repousa em pesquisas prévias, na seleção dos objetos, na documentação, na direção, na administração, conservação e, eventualmente, na restauração. Essa musealização recobre, portanto, ações muito diferentes que dependem de domínios científicos diversos."

Em seu trabalho sobre os conceitos-chave da museologia, Desvallés e Mairesse chamam atenção para a vinculação da musealização e a atividade científica desenvolvida nos museus.

\begin{abstract}
A musealização ultrapassa a lógica única da coleção para estar inscrita em uma tradição que repousa essencialmente sobre a evolução da racionalidade, ligada à invenção das ciências modernas. $\mathrm{O}$ objeto portador de informação, ou objeto-documento musealizado, inscreve-se no coração da atividade científica do museu. Esta é desenvolvida, desde o Renascimento, como atividade que visa a explorar a realidade por meio da percepção sensorial, pela experiência e pelo estudo de seus fragmentos. Essa perspectiva científica condiciona o estudo objetivo e recorrente da coisa conceitualizada como objeto, para além da aura que lhe permeia para Ihe dar sentido. Não se trata de contemplar, mas de ver: o museu científico não apresenta somente os objetos belos, mas convida à compreensão dos seus sentidos. $O$ ato da musealização desvia o museu da perspectiva do templo para inscrevê-lo em um processo que o aproxima do laboratório. (DESVALÉES; MAIRESSE, 2013, p. 58)
\end{abstract}

Maria Lucia N. M. Loureiro (2016, p. 92) destaca outro aspecto entre as múltiplas dimensões da musealização: o processo informacional. Partindo da afirmação de Ulpiano Bezerra de Menezes (apud LOUREIRO, 2016, p. 96) que o "eixo da musealização" é o "processo de transformação do objeto em documento", a

\footnotetext{
${ }^{9}$ No original: "une expression de la tendance humaine universelle à préserver, contre le changement et la dégradation naturels, les éléments de la réalité objective qui représentent des valeurs culturelles que l'homme, en tant qu'être culturel, a besoin de conserver dans son propre intérêt." (STRANSKY apud BRULON, 2017)
} 
autora volta-se para a Ciência da Informação na identificação de uma corrente funcionalista que, diferente da corrente pragmática que limita a noção de documento aos registros gráficos, sobretudo os textuais, admite que tal noção se aplique a tudo aquilo que for passível "de guarda e preservação, pois [é] representante de alguma ação humana ou de algum detalhe da natureza." Sob este aspecto a autora traça também a sua definição de musealização.

A musealização consiste em um conjunto de processos seletivos de caráter infocomunicacional baseados na agregação de valores a coisas de diferentes naturezas às quais é atribuída a função de documento, e que por esse motivo tornam-se objeto de preservação e divulgação. Tais processos, que têm no museu seu caso privilegiado, exprimem na prática a crença na possibilidade de constituição de uma síntese a partir da seleção, ordenação e classificação de elementos que, reunidos em um sistema coerente, representarão uma realidade necessariamente maior e mais complexa. (LOUREIRO, 2016, p. 101)

Outro ponto importante na discussão sobre a musealização é o conceito de musealidade. Stránský (apud BRULON, 2017, p. 413) chamou de musealidade a qualidade que diferencia o objeto comum do objeto de museu (musealia). É no processo de musealização que o objeto de museu ganha o estatuto de semióforos ${ }^{10}$, e nesse sentido sofre a mudança da "realidade" de origem para a construção de uma "realidade" musealizada. (VAZ, 2017)

A musealidade é um atributo que assume caráter definidor e valorativo, uma "especificidade" outorgada por condição do campo da Museologia pela sua via expressiva de representação, o Museu, elemento mediador junto ao meio social da percepção do real através da "sua" realidade construída; assentada no elenco de bens culturais e naturais no seu espaço teórico e prático de "ser" e, ao mesmo tempo, "tratar" o patrimônio, isto é, a herança coletiva. (LIMA apud VAZ, 2017, pp. 37-38)

Segundo Brulon, é geral a confusão entre a realidade musealizada e o conceito de patrimônio cultural, mas para Stránský essa seria uma abordagem muito vaga e passiva, uma vez que a musealização é um processo ativo que perpassa as três ramificações previstas em sua teoria de Museologia, que são seleção, tesaurização e comunicação.

Por seleção, ele entendia a teoria básica que permitiria identificar o "potencial de musealidade" nos objetos, que pode ser fornecido por

\footnotetext{
10 "De um lado estão as coisas, os objetos úteis, tais como podem ser consumidos ou servir para obter bens de subsistência, ou transformar matérias brutas de modo a torná-las consumíveis, ou ainda proteger contra as variações do ambiente. Todos estes objetos são manipulados e todos exercem ou sofrem modificações físicas, visíveis: consomem-se. De um outro lado estão os semióforos, objetos que não têm utilidade, no sentido que acaba de ser precisado, mas que representam o invisível, são dotados de um significado; não sendo manipulados, mas expostos ao olhar, não sofrem usura." (POMIAN, 1984, p. 71)
} 
diferentes disciplinas científicas. A seleção em si mesma, isto é, a retirada de um objeto "portador" de uma situação original, seria dependente do reconhecimento de seu "valor museal". A tesaurização poderia ser compreendida como o processo de inserção do objeto no sistema documental da nova realidade de uma coleção ou museu. Por fim, a comunicação museológica é o processo por meio do qual uma coleção ganha sentido, tornando-a acessível e disseminando o seu valor científico, cultural e educativo. (BRULON, 2017)

Essas colocações de Brulon deixam claro que o processo de musealização perpassa toda a cadeia operatória museológica, da salvaguarda (documentação, conservação) e comunicação (exposição, publicação, ação educativa e avaliação) (BRUNO, 1998).

Tratando da questão da musealização, Waldisa Rússio observa que não musealizamos todos os testemunhos do homem e de seu meio, mas somente os remanescentes que tenham significação. (BRUNO; ARAÚJO; COUTINHO, 2010). Brulon, citando o pensador Klaus Schreiner, aponta que a musealidade não seria entendida como a propriedade intrínseca de um objeto, mas sim algo que the seria atribuído no "âmbito de uma disciplina específica". Dessa forma, o objeto não teria, "um valor em si mesmo".

Observando natureza dos objetos de museu percebemos que os dois pontos de vista se mostram verdadeiros, pois os artefatos carregam em si informações sobre sua materialidade, expressões estéticas e mesmo as marcas de sua trajetória. Da mesma forma, o homem, foco de toda ação museal, é o ser que interpreta os artefatos e atribui a eles significados e valores simbólicos.

Este pensamento pode ser corroborado com a explanação de Rússio a respeito das informações relativas à documentalidade, testemunhalidade e fidelidade contida nos objetos.

Convém lembrar que as palavras documentalidade e testemunhalidade tem, aqui, toda a força de sua origem. Assim, documentalidade pressupõe "documento", cuja raiz é a mesma de docere = ensinar. Daí que o "documento" não apenas diz, mas ensina algo de alguém ou alguma coisa; e quem ensina, ensina alguma coisa a alguém. Testemunhalidade pressupõe "testemunho", cuja origem é testimonium, ou seja, testificar, atestar algo de alguém, fato, coisa. Da mesma maneira que o documento, o testemunho testifica algo de alguém a outrem. Quem testemunha afirma o que sabe, o que presenciou: isto é, o testemunho tem o sentido de presença, de "estar ali" por ocasião do ato, ou do fato, a ser testemunhado.

Fidelidade, em Museologia, não pressupõe necessariamente autenticidade no sentido tradicional e restrito, mas a veracidade, a fidedignidade do documento ou testemunho. (RÚSSIO, 2010b, p. 205) 
Mario Chagas elenca ainda mais alguns valores ou qualidades que podem ser considerados indicadores de musealidade dos objetos de museu: "autenticidade, raridade, beleza, curiosidade, antiguidade, exoticidade, excepcionalidade, banalidade, falsidade, simplicidade, e outras não previstas" e que legitimariam a seleção de determinados objetos para preservação e transmissão às gerações futuras. (CHAGAS apud VAZ, 2017, p. 62)

Desenvolveremos essas discussões com respeito à questão da musealização no terceiro capítulo deste trabalho, aproximando-o do nosso objeto de estudo - obras de arte contemporânea. Interessou-nos também refletir sobre as consequências da não concretização dos processos de musealização em sua completude, em especial, no caso da coleção em estudo.

$\mathrm{Na}$ realização deste trabalho utilizamos fontes escritas produzidas entre meados da década de 1950 e 2002, ano da abertura da Pinacoteca Municipal; utilizamos também fontes orais, resultantes de entrevistas realizadas com alguns atores dessa história. O conjunto de documentação consultado foi baseado, sobretudo, em fontes primárias, como leis, decretos e processos administrativos da Prefeitura Municipal de São Caetano do Sul e da Fundação Pró-Memória de São Caetano do Sul, além de artigos de jornais locais e da grande imprensa. $O$ uso dessas fontes nos possibilitou uma aproximação inédita ao nosso objeto de pesquisa, fornecendo as informações de que tanto carecíamos para a compreensão da formação deste conjunto de obras. Além das fontes primárias, buscamos na leitura crítica de obras de referência nos campos da Museologia, História da Arte, e Estudos de Proveniência os elementos que nos auxiliaram a estabelecer um diálogo entre os diversos autores consultados e as evidências levantadas a partir do acervo estudado. Com tais bases, desenvolvemos a dissertação aqui apresentada onde, o primeiro capítulo será dedicado à reconstituição do cenário político, social e cultural que levou à formação da Coleção dos Salões de Arte Contemporânea estudada e fundou a ideia da criação de um museu de arte na cidade de São Caetano do Sul. Nossa pesquisa buscou traçar um panorama do município em sua estruturação enquanto cidade recém-emancipada ${ }^{11}$, uma consequência de seu notável desenvolvimento industrial, e a construção de sua identidade. Nesse sentido, buscamos analisar o movimento cultural da localidade destacando as ações que

\footnotetext{
${ }^{11}$ São Caetano do Sul ascendeu à categoria de município em outubro de 1948, com a eleição de seu primeiro Prefeito e Câmara Municipal em 1949.
} 
influenciaram, direta e/ou indiretamente, a criação dos salões de arte contemporânea como ato de gestão pública dentro de uma política de educação e cultura. Procuramos também identificar os agentes que movimentaram as engrenagens dessa história que transbordou os limites geográficos da cidade. Outro aspecto analisado neste panorama diz respeito à "opção" pela arte contemporânea em uma cidade localizada no subúrbio de São Paulo, onde prevalecia a história local e cotidiana, distante do protagonismo dos grandes centros. E, sobretudo, procuramos entender em que momento se buscou essa posição de vanguarda, uma vez que as mostras e salões realizados na cidade e na região até então se identificavam com as artes decorativas ou, no máximo, com a arte moderna. Nesse sentido, a cidade de São Caetano do Sul foi precursora de uma tendência que se espalhou pelas demais cidades da região. Por fim, trataremos da criação da Fundação Pró-Memória de São Caetano do Sul e o resgate do projeto de um museu de arte para, assim, compreendermos o papel da Pinacoteca Municipal, criada depois de um hiato de 35 anos, no âmbito de uma instituição cujo principal objetivo é preservar e divulgar a memória e a histórica local. No segundo capítulo, o foco recai nos salões de arte, e particularmente os de arte contemporânea, partindo de um breve panorama desses eventos enquanto prática nacional até a realização do I Salão de Arte Contemporânea em São Caetano do Sul, em 1967. Em seguida, faremos uma análise dos onze salões a partir de seus regulamentos, comissões organizadoras e de seleção e julgamento, chegando finalmente às relações de artistas participantes, das obras inscritas e, principalmente, das obras adquiridas através dos prêmios-aquisição destinadas a compor o acervo artístico municipal ${ }^{12}$.

O último capítulo é dedicado àquilo que apresentamos como nosso terceiro objetivo: uma reflexão sobre a musealização da arte contemporânea e a análise das práticas de colecionismo público tendo os salões de arte como estratégia de formação de coleções.

\footnotetext{
${ }^{12}$ Lei oํ 1.560 de 27 de abril de 1967, que cria o Salão de Arte Contemporânea. (PREFEITURA, 1967a)
} 


\title{
CAPÍTULO 1
}

\section{REFAZENDO CAMINHOS: AS ORIGENS DA COLEÇÃO}

\begin{abstract}
$\mathrm{Na}$ história local e cotidiana estão as circunstâncias da História. É nesse sentido que a história do subúrbio é uma história circunstancial. $O$ que permite resgatá-la como História? A junção dos fragmentos da circunstância - quando a circunstância ganha sentido, o sentido que lhe dá a História.
\end{abstract}

(José de Souza Martins)

Buscar as intencionalidades por trás da criação de um acervo, especialmente de um acervo de arte, pode nos ajudar não somente a compreender a coleção em si e a instituição que a abriga, mas também nos possibilita novas visões sobre o estabelecimento de políticas de aquisição, de exposição e mesmo de ação educativa. Ou seja, pode dar novos rumos e sentidos à totalidade de ações da instituição museológica. Para isso, faremos neste capítulo um mergulho na história da cidade de São Caetano do Sul.

Mas não é possível falarmos da história de São Caetano sem compreendermos um pouco sobre seu entorno. O território conhecido como "Região do Grande $A B C " 13$ tem uma história bastante peculiar, que recua aos primórdios da colonização brasileira com a fundação da Vila de Santo André da Borda do Campo, por João Ramalho em 1553, passando por sua incorporação à Vila de São Paulo, sua transformação em freguesia em 1814, e, com a Proclamação da República, a sua elevação a Município de São Bernardo. Outra peculiaridade dessa região é sua posição geográfica estratégica entre a cidade de São Paulo e o litoral. Tal condição, de "caminho do mar", fez com que suas terras fossem rasgadas pelos trilhos da São Paulo Railway Company, a estrada de ferro que ligava Jundiaí, ponto de concentração da produção cafeeira, ao Porto de Santos. A ferrovia trouxe consigo as

\footnotetext{
${ }^{13}$ Hoje a região do Grande $A B C$ é formada por sete municípios: Santo André, São Bernardo do Campo, São Caetano do Sul, Diadema, Mauá, Ribeirão Pires e Rio Grande da Serra.
} 
condições que levaram à formação de um grande eixo de industrialização em seu entorno. $^{14}$

O distrito São Caetano teve suas origens com a formação da Fazenda São Caetano pertencente ao Mosteiro de São Bento (1631-1877), passando também pela experiência da imigração italiana realizada pelo Governo Imperial e pela Província de São Paulo através do Núcleo Colonial de São Caetano. ${ }^{15}$ Em 1938, a região passou por um grande rearranjo geopolítico: o desenvolvimento econômico em torno da ferrovia se tornava cada vez mais intenso, favorecendo os distritos que se localizavam no entorno das estações, principalmente o distrito de Santo André, ocasionando o surgimento de novos grupos hegemônicos.

O trinômio ferrovia, água e terrenos grandes, planos e baratos foi um dos fatores primordiais para a implantação industrial na faixa São Caetano/Santo André, principalmente as indústrias que necessitavam de matérias-primas importadas e, portanto teriam uma localização vantajosa ao longo da ferrovia que liga São Paulo ao Porto de Santos. Também foi de grande contribuição a mão-de-obra estrangeira localizada nos núcleos coloniais de São Caetano e São Bernardo. (KASSEB, 1990?, p. 8)

No caso do Distrito de Santo André, esse trinômio somou-se um reavivamento do interesse pela antiga Vila de João Ramalho e, sob os auspícios do interventor federal do governo de Getúlio Vargas, foi feita a troca do nome do Município que passou a ser Santo André. Com essa mudança, o centro da cidade e seu do núcleo administrativo muda-se para o bairro da estação. $O$ antigo centro da cidade passa a ser o distrito de São Bernardo, e São Caetano torna-se então um subdistrito.

Essas mudanças geraram repercussão nessas localidades dando início a vários movimentos emancipacionistas.

A partir do município de Santo André, num período de tempo relativamente
curto - de 1945 a 1963 - foram criados sete novos municípios: São Bernardo
do Campo (desmembrado em 1945), São Caetano do Sul (desmembrado
em 1948), Mauá e Ribeirão Pires (desmembrados em 1953), Diadema
(desmembrado em 1958) e Rio Grande da Serra (desmembrado em 1963)
(...)
Nesse mesmo período, outros municípios que hoje compõem a região
metropolitana também passaram por processos semelhantes de
desmembramento. Cotia e Itapecerica da Serra, no mesmo período,
desmembraram-se em quatro outros municípios cada e Mogi das Cruzes em
cinco outros, mas nenhum deles apresentando industrialização e

${ }^{14}$ A industrialização torna a região um polo de atração para imigrantes das mais diferentes nacionalidades e migrantes, principalmente do interior de São Paulo e do Nordeste.

${ }^{15} \mathrm{O}$ conhecimento que se tem sobre o passado colonial da cidade de São Caetano do Sul se deve ao trabalho de mais de 30 anos de pesquisas realizado pelo Prof. Dr José de Souza Martins, que se iniciou com a publicação de seu primeiro livro São Caetano do Sul em Quatro Séculos de História, em 1957. 
consequente urbanização tão grandes quanto $O A B C$, que recebe, consequentemente, o maior número de população migrante também no período.

Além disso, nenhum desses municípios, ou conjunto de municípios, parece carregar consigo uma "identidade regional" como aqueles do ABC. Identidade essa, que percebemos no decorrer da pesquisa, construída pelo mando local quando o fenômeno metropolitano começa a ganhar realidade, promovendo a anexação funcional do entorno da cidade de São Paulo.

No período estudado, tal identidade regional ainda está sendo gestada (ela ganha corpo em meados da década de cinquenta), juntamente com a criação desses novos municípios - novos espaços de poder - que vão sendo "reapropriados", ou pelos velhos "donos" do lugar, ou por novos personagens que entraram em cena com a industrialização do subúrbio, trazendo consigo o germe da modernidade. (KUVASNEY, 1996, 10 a 11)

Os processos de autonomia deixaram fraturas na relação entre as novas cidades e certo clima de competitividade passou a imperar na relação entre elas, principalmente entre as três que possuíam os maiores parques industriais - Santo André, São Bernardo do Campo e São Caetano do Sul.

Para São Caetano, esse rearranjo foi entendido como um rebaixamento de categoria, pois desde a década de 1910 a localidade vivenciava um intenso processo de industrialização. Isso acirrou os ânimos de vários grupos locais e culminou com a criação do Movimento Autonomista em 1946. Esse movimento, que teve um grande engajamento da população local, foi vitorioso no plebiscito realizado dois anos depois. Estava criado o novo município - São Caetano do Sul ${ }^{16}$. A cidade que aí nascia tinha a sua frente um grande desafio a ser enfrentado.

Se, por um lado, o alto nível de industrialização da localidade foi decisivo
para o acúmulo de riquezas e a obtenção de sua emancipação política, fato
que Ihe atribuiu a qualidade de município, por outro, o cenário vigente,
durante os seus primeiros anos de vida política autônoma, era de incipiência
estrutural, no que concerne à oferta de serviços urbanos primordiais, tais
como educação, saúde e saneamento básico, revelando uma situação de
pobreza, insalubridade, desigualdades sociais e de disseminação de
doenças e epidemias. A pobreza, na virada da década de 1940 para o
decênio de 1950, dava o tom na cena urbana da localidade. Os cortiços se
proliferavam, constituindo-se na forma de moradia mais comum entre os
setores desfavorecidos da população, compostos, maciçamente, por
migrantes nordestinos. Estes, atraídos pela possibilidade de ingresso nas
fileiras das indústrias locais, chegavam à cidade em grandes levas, naquele
período. Suas necessidades mais urgentes se colocavam ao lado das que
já estavam em curso no cotidiano de São Caetano, oriundas dos demais
setores sociais. O descompasso existente entre as demandas e a oferta de
serviços públicos por parte da municipalidade contribuiu para que ações
destinadas à promoção da estruturação da cidade figurassem como pauta
prioritária nas agendas das primeiras administrações municipais.
(CARVALHO, $2017 a$, p. 8 )

${ }^{16}$ O novo município de São Caetano recebeu o complemento "do Sul", porque na ocasião de sua criação, já existia uma cidade com este nome no Estado de Pernambuco. 
Com uma infraestrutura urbana tão deficiente, é compreensível que o foco das administrações públicas recaísse sobre os serviços urbanos básicos durante a primeira década pós-autonomia. As obras de saneamento e pavimentação foram priorizadas, deixando as demais áreas, como saúde e educação, em segundo plano. Assim, até os fins da década de 1950, São Caetano do Sul mantinha as características de subúrbio da capital paulista.

Para população de São Caetano do Sul, formada em grande parte por imigrantes, não era estranha a prática de, nos momentos de ausência da ação pública, organizar-se em busca das próprias soluções. ${ }^{17}$ Isso pode ser constatado pela presença de sociedades de auxílio-mútuo - Società di Mutuo Soccorso Principe di Napoli (1892 a 1988), Sociedade Beneficente Internacional União Operária (de 1907 aos dias atuais), Sociedade Beneficente Brasil Unido (de 1907 aos dias atuais), Sociedade Beneficente Hospitalar São Caetano (1946 a 2010), Sociedade Portuguesa de Beneficência de São Caetano (de 1949 aos dias atuais). As duas últimas foram responsáveis pela construção e funcionamento de dois hospitais. Além dessas iniciativas, deve-se considerar o próprio movimento pela autonomia da cidade, que contou com um grande engajamento popular. (Figura 2)

É interessante notar que essas associações nos remetem aos modelos das organizações do Governo de Mussolini (os fasci all'estero, as Case d'Italia e o Dopo Lavoro $^{18}$ que tinham um importante papel dentro da política externa italiana, buscando ampliar a influência da ideologia fascista na América do Sul. No caso brasileiro, essa política encontrou eco na Ação Integralista Brasileira (AIB). (BERTONHA, 2017).

Não podemos deixar de inferir a influência de tais modelos nas instituições locais uma vez que muitos de seus idealizadores, como imigrantes italianos ou descendentes diretos destes, eram simpatizantes do movimento fascista ou dos integralistas. Essa influência pode ser identificada pela interpretação triunfalista da

${ }^{17}$ Essa foi a realidade de muitas populações imigrantes e migrantes que sofreram reiteradamente com a ausência de política públicas dos órgãos oficiais seja no período Imperial ou no governo Republicano.

${ }^{18}$ Criada em 1925, a Opera Nazionale Dopolavoro (OND) era um dos principais instrumentos de política social do fascismo e seu projeto era afastar os operários dos ambientes de socialização popular e política e envolvê-los em atividades que comportassem a gestão de seu tempo livre pela empresa ou pelo Estado. Por suas atividades físicas, recreativas e culturais, as OND se tornaram muito populares na Itália, despertando no governo fascista as possibilidades de utilizar os Dopolavoro para exercer influência sobre as comunidades italianas no exterior. Na América Latina, a difusão dos Dopolavoro foi ampla, com atuação nos países de grande imigração italiana como Brasil e Argentina, mas também uma presença significativa na América Central e no Peru. (BERTONHA, 2017) 


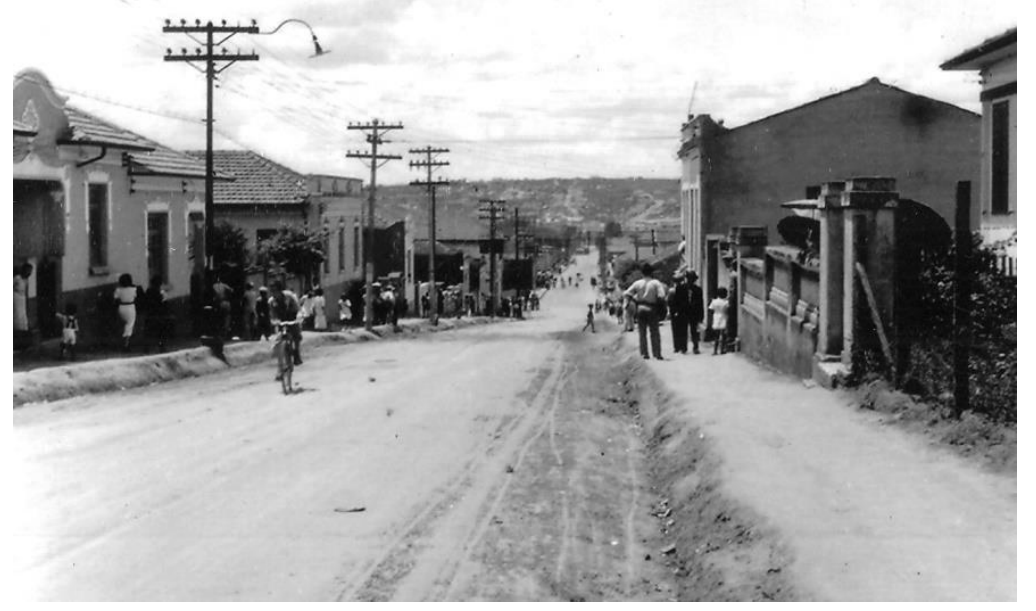

Figura 1 - Rua Amazonas entre os bairros Santo Antônio e Santa Paula, década de 1940. Acervo Fundação Pró-Memória de São Caetano do Sul

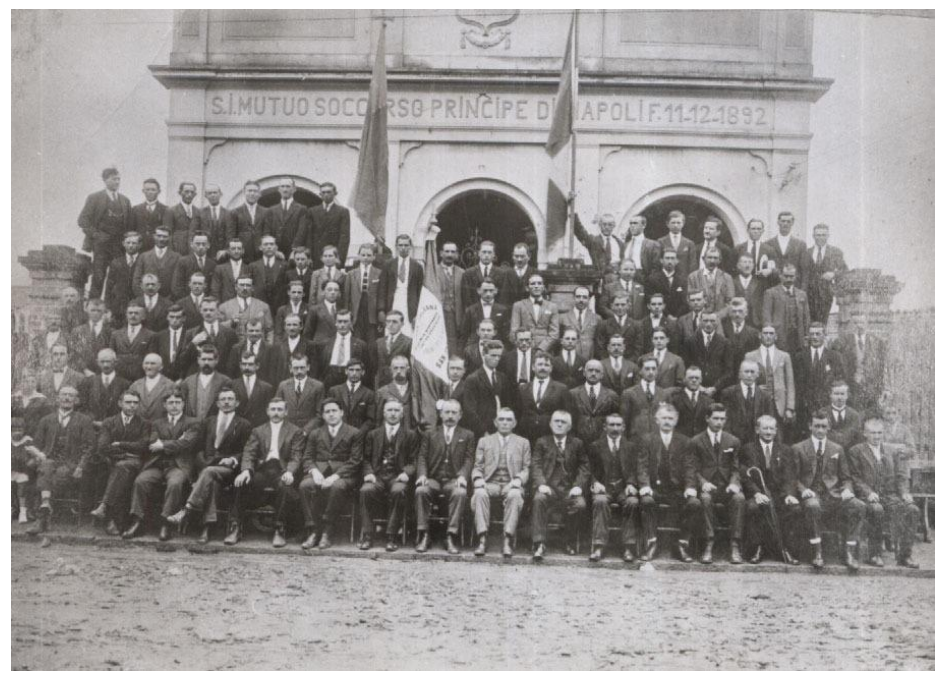

Figura 2 - Membros da Società di Mutuo Soccorso Principe di Napoli em frente à sua sede na Rua Perrella Bairro Fundação, 1927.

Acervo Fundação Pró-Memória de São Caetano do Sul 
imigração italiana em São Caetano que se consolidou a partir da comemoração do cinquentenário da fundação do núcleo colonial.

[...] em 1927, o fascismo estava em ascensão na Itália e foi na perspectiva de uma mentalidade fascista e triunfalista, na perspectiva do poder e do progresso, que o aniversário de São Caetano foi noticiado nos jornais da Itália e nos jornais italianos do Brasil. Naquela época, a embaixada italiana e os consulados procuravam ter presença ativa nos núcleos populacionais italianos, através de agentes e simpatizantes do fascismo, responsáveis pela construção de uma mística italiana e fascista - a mística da unidade nacional, do triunfo da italianidade e do poder centralizado, expressos na lealdade pessoal ao Duce. Não havia motivo para que em São Caetano as coisas fossem diferentes. É muito significativo que da comissão dos festejos do cinquentenário, em 1927, fizesse parte Ettore Lantieri, sócio da firma Lantieri \& Marengo (a fábrica de velas que existiu na esquina das ruas Antônio Prado e Santo Antônio), que chegara a São Caetano em 1914. [...] Foi apresentado numa publicação da época como "fervoroso admirador da política de Mussolini". Da mesma comissão fez parte Luigi Martorelli, de família de fundadores do núcleo colonial, que igualmente se identificava com o fascismo.

Um foco de influência e de presença fascista em São Caetano era o conjunto de fábricas do Conde Francisco Matarazzo. Diretores locais, chefes e técnicos tinham ligações com o fascismo. (MARTINS, 1992, pp. 2527)

Podemos notar que essa ligação se prolongou no tempo. Até os dias atuais, a chegada dos imigrantes e a implantação do núcleo colonial são consideradas o marco de fundação de São Caetano do Sul e não a sua autonomia administrativa, que de fato criou o município. ${ }^{19}$ Também é interessante observar que, Mário Dal'Mas $^{20}$, um dos "personagens" mais atuantes nos fatos que relataremos a seguir, é membro de uma das famílias de fundadores e que também eram simpatizantes do Movimento Integralista.

Essa tradição associativista também foi uma realidade na área cultural, com a criação da Associação Cultural e Artística de São Caetano do Sul (ACASCS), em 1957, por iniciativa de um grupo de "jovens amantes das artes e cultura" (A.C.A.S.C.S., 1963).

Com a criação da Associação Cultural e Artística de São Caetano do Sul (ACASCS), em 1957, um novo ciclo cultural procurou preencher a lacuna que vinha se acentuando com a diminuição das atividades culturais nos clubes. A nova e a velha guardas teatrais locais juntaram-se em uma associação inteiramente dedicada à cultura em todas [as] suas

${ }^{19}$ O aniversário da cidade de São Caetano do Sul é comemorado no dia 27 de julho, data da chegada da primeira leva de imigrantes italianos à localidade.

20 Mario Dal'Mas (1923-2019), filho de antiga e tradicional família de industriais da cidade, é engenheiro formado pelo Instituto Presbiteriano Mackenzie e ativo participante do Movimento Autonomista. Sempre foi ativo na vida cultural da cidade, principalmente no teatro, onde como ator, atuou em dezenas de espetáculos. Foi o segundo presidente da Associação Cultural e Artística de São Caetano do Sul. 
manifestações, resultando em uma notável produção cultural. Outras entidades, inclusive estudantis, formaram, na década de 1960, seus próprios grupos de teatro. (GARBELOTTO, 2014, p.15-16)

Congregando parte da elite intelectualizada da cidade, a ACASCS dedicou-se à promoção das mais diversas ações em prol do desenvolvimento cultural local.

Para quem chegasse a São Caetano do Sul no início dos anos 60, não era difícil identificar onde se centralizavam as atividades culturais da cidade. A Associação Cultural e Artística de São Caetano do Sul (ACASCS), fundada em 1957, estava instalada bem no centro, no quarto andar do Edifício Vitória, à Rua Santo Antônio, 500, onde também tinham sede o Clube Comercial e o Cine Vitória. A tradição social e recreativa, cara aos imigrantes italianos, abria-se, então, para um contingente mais diversificado, quando uma nova onda de imigrantes, estimulada pela intensa industrialização do $A B C$, vinha procurar o seu destino nessa cidade.

A ACASCS representou nesses anos referência importante na vida cultural da cidade, atraindo a participação para o teatro, a música, conferências, além das atividades esportivas. (SILVA, 2000a, p. 64-65)

Sob o lema "Pela Arte e pela Cultura", as ações da ACASCS se desenvolveram de tal maneira que a associação, a partir dos anos de 1960, passou a se organizar em departamentos voltados à promoção de espetáculos e eventos sociais e artísticos, além de cursos de formação dentro das modalidades artísticas nas quais atuava. (Figura 3 )

O Departamento Lírico era responsável pela promoção de eventos musicais tais como recitais de canto, de piano, concertos sinfônicos etc., sendo também responsável por um grupo de canto coral. Outro departamento de destaque era o de Teatro, que com um grupo experimental encenou várias peças teatrais relevantes, considerando-se o momento histórico em que se encontravam ${ }^{21}$, como Fogo Frio, de Benedito Rui Barbosa; As Máscaras, de Menotti Del Picchia; A Ceia dos Cardeais, de Júlio Dantas e uma das primeiras montagens da peça Odorico (o bem amado), de Dias Gomes, em 1964. Mas o setor de maior interesse no nosso trabalho era o Departamento de Escultura e Pintura, sobre o qual discorremos mais à frente, uma vez que ele está ligado à criação dos Salões de Arte Contemporânea.

Havia ainda os Departamentos de Ballet, de Cine-foto (que promovia apresentação de filmes), de Discoteca, de Biblioteca, de Esportes e Jogos (com torneios de ping-pong e xadrez), de Cultura (que promovia conferências e palestras), Social (que promovia bailes e piqueniques), de Magia (com espetáculos de prestidigitação) e de propaganda e difusão. Além das atividades artísticas, havia

${ }^{21}$ Nesse período, iniciava-se o regime cívico-militar no país, com a censura e as liberdades democráticas em suspenso. 
também um Departamento Feminino, dedicado às ações filantrópicas. É interessante ressaltar que os departamentos Lírico, de Ballet, e de Escultura e Pintura realizavam cursos de formação artística, voltados principalmente para crianças.

Entre ações voltadas exclusivas aos associados e outras abertas ao público em geral, o alcance da ACASCS não se restringia à população sul-são-caetanense. Como observou a historiadora Cristina Toledo de Carvalho, o próprio poder público se valia das ações programadas pela associação para compor o seu calendário de eventos, principalmente aqueles dedicados aos festejos de aniversário da cidade (CARVALHO, 2014).

Esse cenário começa a se transformar a partir de meados da década de 1960, com a primeira administração do prefeito Hermógenes Walter Braido ${ }^{22}$, com uma gestão voltada à adoção de políticas em favor de um planejamento urbano com o objetivo de dotar o município de equipamentos e serviços a partir de uma visão de desenvolvimento e modernização (CARVALHO, 2017a).

Esse anseio pela modernidade era uma tônica do Grande ABC. Guindadas ao patamar de grande polo industrial, as cidades da região buscaram caminhos de identificação com a "modernidade", capitalizando os resultados e a posição advindos dos avanços das forças produtivas capitalistas. Era também um reflexo do Governo de Juscelino Kubitschek que aliou estabilidade política a anos de otimismo embalados por altos índices de crescimento econômico. Seu governo foi associado à instalação da indústria automobilística, embora antes já existissem montadoras e fábricas de autopeças no país, como a General Motors, que se transferira para São Caetano em 1930. No entanto, com uma legislação que facilitava os investimentos estrangeiros em áreas prioritárias, esse movimento intensificou-se e outras grandes empresas multinacionais como Willys Overland, Ford, Volkswagen também se concentraram na região do $\mathrm{ABC}$, provocando mudanças intensas neste território (FAUSTO, 2006). Mas não só a indústria automobilística movimentava o subúrbio

\footnotetext{
${ }^{22}$ Hermógenes Walter Braido (1927-2008) era descendente de imigrantes italianos, pertencendo a uma das famílias "fundadoras" do núcleo colonial, família Braido, que é um paradigma do imigrante "vencedor" que, partindo dos tempos de pobreza na chegada ao País, conseguiu se capitalizar através de sua olaria para entrar no ramo industrial com fábrica de processamento de sebo e ossos que existe até os nossos dias - a Agroquímica Braido. Em 1951, Walter assume o negócio da família com seu irmão Nelson. Ao mesmo tempo, engaja-se numa política partidária da cidade, onde conseguiu um grande destaque sendo vereador (1957-1961) e prefeito por três gestões (1965-1969/ 1973-1977/ 1983-1988). Destacou-se como administrador público, deixando sua marca no desenvolvimento e estruturação da cidade de São Caetano do Sul. Mesmo não ocupando mais nenhum cargo eletivo, foi um grande influenciador da política municipal até sua morte.
} 
A. C. A. S. C. $\mathbf{S}$.

Departamento de Teatro

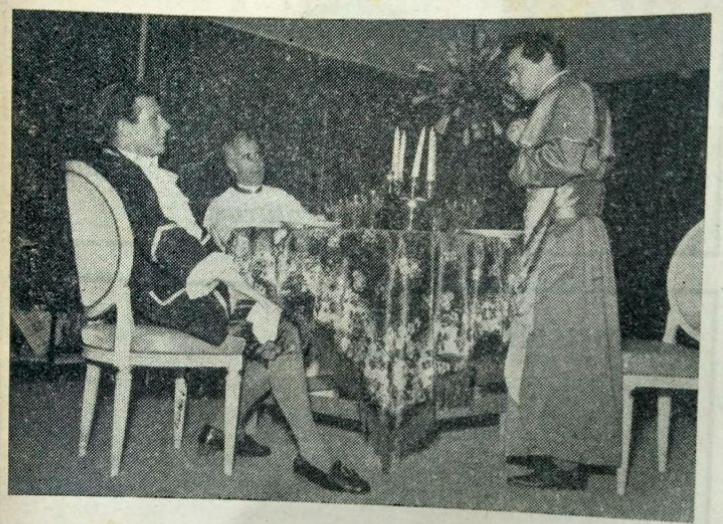

A representação da peça de Julio Dantas "Ceia dos Cardiais" Nelson Infanti direção de Milton Andrade com a participação de Waldemar Gianoti,
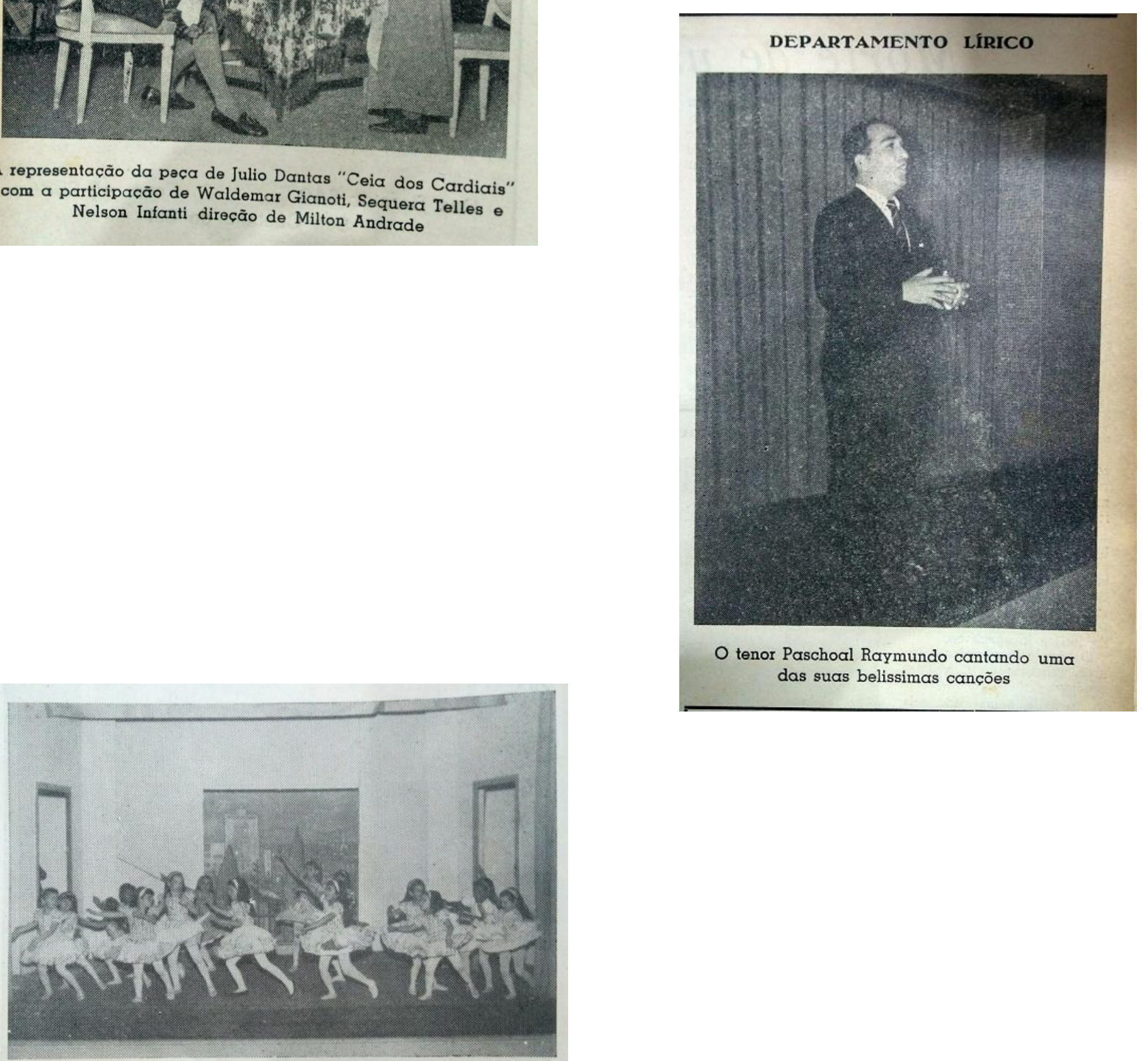

Um dos mais lindos quadros do Ballet apresentado no Aud. Municipal

Figura 3, 4 e 5 - Algumas ações desenvolvidas pela Associação Cultural e Artística de São Caetano do Sul, em 1964. Fonte: ACASCS Jornal 
paulistano: outros ramos industriais, como a cerâmica, a química e a tecelagem contribuíram para essas transformações.

O programa de metas do governo Juscelino Kubitschek, iniciou uma nova etapa de industrialização baseada na produção de bens de consumo duráveis, bens intermediários e de capital (eletrodomésticos, automóveis, máquinas, equipamentos, etc.) e que consistia na substituição das importações.

Trata-se de indústrias de porte, de alta produtividade, tecnologia avançada, que exigem alto investimento de capital e concentram grande número de empregos devido ao seu porte. No que se refere à ocupação do espaço urbano, este tipo de indústria caracteriza-se pelo fato de ser dinâmica atraindo para o seu entorno suas fornecedoras, ou serviços ligados à produção.

As indústrias automobilísticas, de construção naval e siderurgia são privilegiadas pela reforma da legișlação tarifária e pela concessão de câmbio de custo para importações. É criado o G.E.I.A. (Grupo Executivo da Indústria Automobilística), que através de sucessivos decretos, fixou as bases para o rápido desenvolvimento da indústria automobilística brasileira. (KASSEB, 1990?, p. 17)

No âmbito estadual, o Governo de Carvalho Pinto trouxe "uma das primeiras experiências de planejamento de políticas públicas no conceito de planejamentoorçamento" (BUZZAR; CORDIDO; SIMONI, 2015, p. 159). O Plano de Ação do Governo do Estado (PAGE) teve como finalidade a melhoria das condições de infraestrutura do estado, visando à consolidação da liderança do estado de São Paulo no contexto brasileiro.

PAGE, como era conhecido - teve por objetivo a criação de uma tecnocracia democrática para racionalizar o serviço público e promover 0 desenvolvimento do Estado de São Paulo, cujos investimentos foram estruturados em três setores: 1 - melhoria das condições do Homem, que incluía as áreas de educação, cultura e pesquisa; justiça e segurança; saúde pública e assistência social, e sistemas de água e esgoto; 2 infraestrutura, abrangendo energia; ferrovias; rodovias; pontes municipais; aeroportos, portos e navegação; e 3 - expansão agrícola. (CAMARGO, 2016, p. 165)

Na memória coletiva, o governo de Juscelino Kubistchek é lembrado como um período de otimismo associado a grandes realizações, cujo expoente maior é Brasília como materialização da modernidade. Nesse sentido, o Plano Ação do Governo do Estado também teve uma grande contribuição. Os investimentos realizados pelo PAGE permitiram a construção, ampliação e reforma de mais de mil equipamentos públicos por todo o Estado que, de certa forma, "tornou o Estado permeável ao modernismo", representando, assim, uma ruptura com a arquitetura antes praticada pelo Departamento de Obras Públicas, que era quase que 
exclusivamente eclética, mesmo no momento em que a arquitetura moderna já era hegemônica entre os arquitetos". (BUZZAR; CORDIDO; SIMONI, 2015).

O modernismo em arquitetura se atrela cada vez mais ao universo simbólico do novo, representado pelo desenvolvimento industrial em confronto ao com o antigo, representado pelo país agrário. Como vaticinou Mário Pedrosa, ao falar do Brasil como um país "condenado ao moderno", por ser um país criado a partir do "zero" a partir da chegada dos portugueses, e que teve como primeira manifestação artística o Barroco - uma arte de "vanguarda" (PEDROSA, 1981).

Uma forma de identificação de São Caetano com a modernidade dessa época foi a adoção da arquitetura moderna. O primeiro grande exemplo foi a construção do Paço Municipal, uma vez que, desde a autonomia política, a municipalidade não possuía sedes administrativa e legislativa próprias. A partir de uma promessa de campanha do terceiro prefeito eleito, Oswaldo Samuel Massei, ${ }^{23}$ foi convidado o engenheiro arquiteto Zenon Lotufo para a realização de um projeto que trouxesse o conceito de modernismo que a municipalidade almejava concretizar por meio da arquitetura $^{24}$ (CARAM, 2002).

O projeto do Paço Municipal previa, além da Prefeitura, as instalações da Câmara Municipal, do Fórum e da Biblioteca Municipal em um prédio anexo. Foi projetada também uma Concha Acústica na Praça $1^{\circ}$ de Maio, que ficava ao lado do futuro Paço.

Uma das principais determinações estabelecidas pela administração municipal dizia respeito à grandiosidade da obra.

O Paço deve ser instalado condignamente em prédio central, a fim de
facilitar o acesso dos munícipes. Deve ser um prédio destacado, com
facilidade de ordem viária e, se possível, no centro de um jardim ou praça,
principalmente para a formação do centro cívico, onde se realizarão as
paradas e desfiles, onde poderá fazer-se (sic) concentrações populares (...).
É que no projeto original do Paço o edifício deveria contar com dois blocos:
no posterior (que foi construído) ficariam as repartições municipais,
constituindo a Prefeitura propriamente dita, e no bloco anterior (não
construído) estariam localizadas a Câmara, o Fórum, e a Biblioteca. Os dois
blocos seriam ligados por um passadiço formando um verdadeiro Centro

${ }^{23}$ Gestão de 1957 a 1961.

${ }^{24}$ Zenon Lotufo (1911-1985) nasceu em Botucatu e concluiu os estudos de engenharia no Rio de Janeiro. Transferiu-se para São Paulo onde foi o primeiro engenheiro-arquiteto formado pela Escola Politécnica de São Paulo, em 1936. Quando assumiu a responsabilidade do projeto do Paço Municipal de São Caetano, vinha respaldado pela fama de ter participado da equipe que projetou o Parque do Ibirapuera, construído para a exposição comemorativa do IV Centenário de São Paulo, na equipe que contava com Oscar Niemeyer, Hélio Uchôa e Eduardo de Mello além de outros arquitetos de renome. 
Cívico, com os três poderes reunidos, configurando uma ideia muito difundida na época, baseada no projeto da Praça dos Três Poderes de Brasília, de Oscar Niemeyer, e que resultou em vários projetos posteriores de centros cívicos como os construídos em Santo André e São Bernardo do Campo. (ANTIGO, 2000, pp. 40-42)

Embora o projeto original não tenha sido integralmente realizado, o Paço Municipal foi inaugurado em 19 de março de 1961. A partir daí, a arquitetura moderna tornou-se o padrão construtivo para os prédios públicos nas duas próximas décadas.

São Caetano do Sul foi a primeira cidade da região a implantar esse modelo de Paço e Centro Cívico como uma grande intervenção arquitetônica na cidade. Os Centros Cívicos de Santo André e de São Bernardo do Campo seriam inaugurados somente no final da década de $1960 .^{25}$

Essa visão de modernidade continuou muito presente no programa de governo apresentado pelo prefeito Hermógenes Walter Braido. Com o título de Cidade Nova, este programa se desenvolveria a partir de cinco eixos fundamentais: Educação, Saúde, Serviços Públicos, Segurança Público e Esporte, sendo a Educação a prioridade máxima da gestão. Isso pode ser visto pelo slogan que se tornou muito conhecido na época: "São Caetano lugar onde escola não é problema". No caso da cidade, a modernidade não era vista somente pelo desenvolvimento material e urbanístico, mas também na elevação do potencial humano de sua população, ainda que o investimento fosse dirigido para sua preparação $e$ desenvolvimento enquanto forças produtivas (Figura 5).

Para dar uma ideia do perfil da cidade, em meados de 1960, São Caetano do Sul, com seus $15 \mathrm{~km}^{2}$ de extensão, uma população de 180 mil habitantes e a maior densidade demográfica de todo país, era o quinto município do Estado de São Paulo em valor da produção. A renda média das famílias, em comparação com as demais cidades da região metropolitana, só era inferior à da capital. Somente a indústria absorvia cerca de 24.000 pessoas em suas atividades produtivas. Os demais setores empregavam entre 10 e 12 mil pessoas (PREFEITURA, 1968b).

A procura de certos serviços básicos, tais como ensino, assistência médica e hospitalar, recreação, abastecimento de água, esgotos, coleta de lixo, iluminação pública, etc. cresceu muito com o aumento da população e das

\footnotetext{
${ }^{25}$ Para o Centro Cívico de Santo André foi realizado um concurso nacional para escolha do projeto, sendo vencedor o escritório Rino Levi Arquitetos Associados. Esse Centro Cívico foi inaugurado em 1968, com a abertura do $1^{\circ}$ Salão de Arte Contemporânea de Santo André (KLEEB, 2011). Já o Centro de São Bernardo do Campo, com projeto dos arquitetos Jorge Bonfim, Toru Kanazawa e Roberto Monteiro, foi inaugurado em 1969 (BOSCARDIN, 2012).
} 

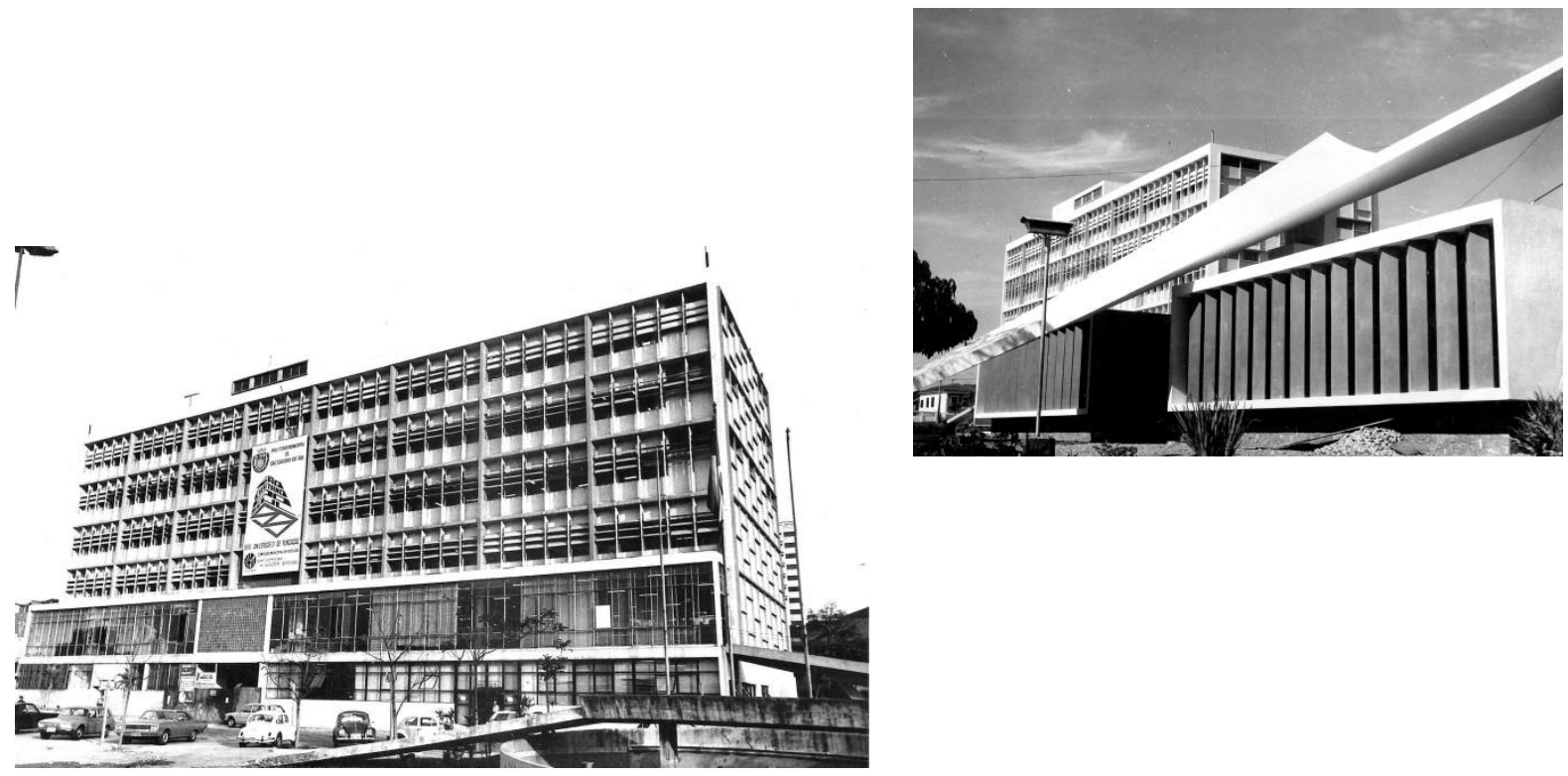

Figuras 6, 7 e 8 - Paço Municipal e Concha Acústica projeto Zenon Lotufo, 1961

Acervo Fundação Pró-Memória de São Caetano do Sul

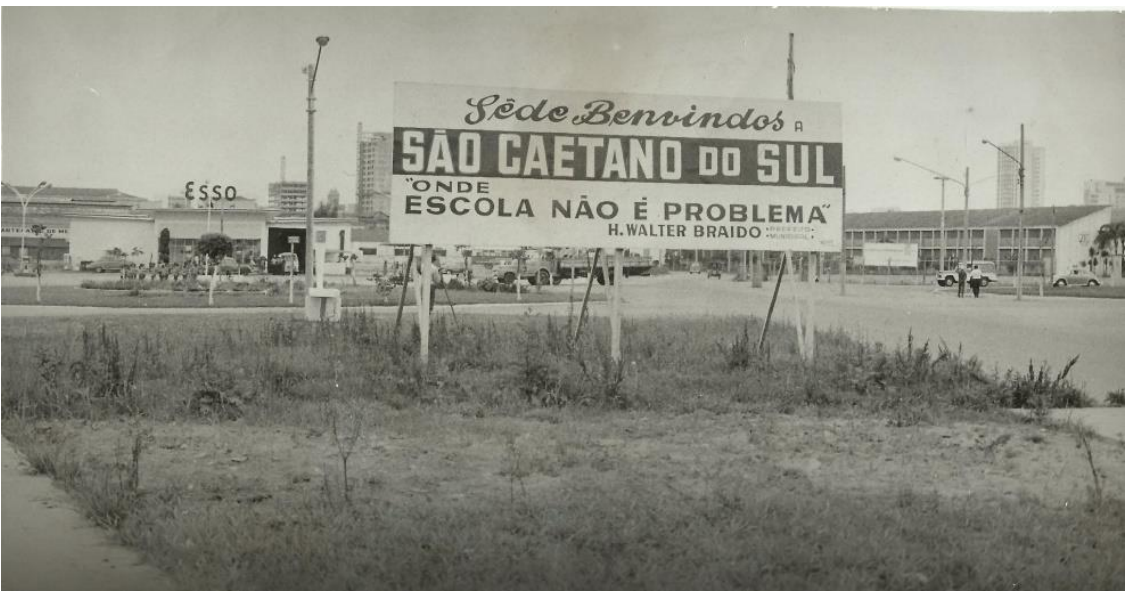

Figura 9 - Entrada da cidade, final da década de 1960. Acervo Fundação

Pró-Memória de São Caetano do Sul 
atividades econômicas. Inúmeros equipamentos urbanos foram, aos poucos, tornando-se insuficientes. Isso sem falar das calamidades públicas eventuais, como as enchentes do Tamanduateí e Meninos. E da necessidade de ampliar as instalações dos serviços públicos.

Por onde começar? Mesmo com os recursos financeiros de que a Prefeitura dispõe, não haveria condições de atacar todos os problemas simultaneamente. Por onde começar? Essa dúvida preocupou o Prefeito $\mathrm{H}$. Walter Braido no início de sua gestão.

Começou pelo ensino, recreação e cultura, saúde e construção das avenidas marginais. Só para educação, cultura e recreação foram destinadas $20 \%$ da despesa municipal entre 1965 e 1967. Isso significou NCr\$ 8.953 mil. Para saúde, NCr\$ 3.368 mil. Grandes verbas foram empregadas na canalização de córregos e abertura de avenidas marginais. Outro tanto para o controle da poluição. (PREFEITURA, 1968b, p. 12-14)

A implantação de tal programa exigiu uma reestruturação administrativa. Uma das principais mudanças foi a elevação do Serviço de Educação a Departamento de Educação e Cultura (DEPEC), em 1966. O diretor responsável por este departamento era o advogado Oscar Garbelotto ${ }^{26}$. Descendente das primeiras famílias italianas a chegar ao Núcleo Colonial São Caetano em 1878, Garbelotto fazia parte da elite letrada da cidade, sendo um entusiasta das manifestações culturais.

Carro-chefe do primeiro mandato de Braido, o segmento educacional absorveu os maiores investimentos e realizações de sua gestão, que, por força disso, notabilizou-se pelo slogan: "São Caetano do Sul, cidade onde escola não é problema." Beneficiada pela concessão de verbas e pela celebração de convênios com o governo estadual, a política municipal impressa à área da educação foi alvo de reconhecimento e elogios, como os proferidos pelo secretário dos Negócios da Educação do Estado de São Paulo, para quem a localidade sul-são-caetanense era, na época, o município "mais bem dotado de escolas de todo o Brasil." (CARVALHO, 2018, p. 11).

A criação do DEPEC possibilitou a organização de um aparato burocrático capaz de gerir e respaldar as ações que deram viabilidade a tal política, uma vez que dentro dessa diretoria havia uma seção destinada exclusivamente à Cultura. Assim, esse departamento se tornou um dos mais dinâmicos da administração municipal.

${ }^{26}$ Oscar Garbelotto (1932-2019) nasceu em São Caetano do Sul e era descendente de uma das famílias fundadoras do Núcleo Colonial. Formado em direito pela Universidade Católica de Campinas, onde foi colega de turma de Milton Andrade. Atuou na gestão pública em vários momentos, nas áreas de educação e jurídica. Grande entusiasta da área cultural foi figura chave dos feitos estudados nessa dissertação. Foi professor e diretor do Instituto Municipal de Ensino Superior (IMES). Foi também memorialista, membro do GIPEM (Grupo Independente de Pesquisadores da Memória do Grande $A B C$ ), e um dos idealizadores e primeiro presidente da Fundação Pró-Memória de São Caetano do Sul. 


\begin{abstract}
Apesar de se tornar município autônomo em 1948, a cultura ainda se ressentia de maior atuação oficial na cidade. A criação do Departamento de Educação e Cultura, em 1965, no primeiro governo do prefeito Hermógenes Walter Braido, consolidou o interesse de transformar São Caetano em referência cultural, ao lado da nova filosofia quanto à educação da cidade, que tinha como slogan "Onde Escola Não É Problema". Fui convidado para assumir o departamento e organizei duas seções. Para chefiar a área de cultura, convidei um amigo que havia estudado comigo na universidade, Milton Andrade, atuante como diretor e ator de teatro da ACASCS. Já havia, entre nós, ideais culturais comuns, daí a afinidade e a harmonia para ousar nos projetos. (GARBELOTTO, 2014, p. 16)
\end{abstract}

O planejamento para área educacional realizado pelo novo departamento foi baseado em um estudo contratado previamente que, a partir de um diagnóstico da situação da educação no município, desenhou um amplo plano de ação para o desenvolvimento educacional em todos os níveis, começando do infantil até a comunidade não escolar. É interessante observar como as ações desenvolvidas pela administração municipal se basearam nesse plano. Com maior ou menor sucesso, todos os pontos levantados por esse estudo foram transformados em ações concretas para a cidade.

A qualidade do Plano Educacional desenvolvido ganhou destaque: depois de ser apresentado no Congresso Paulista de Municípios, realizado em Campos do Jordão, e no Congresso Hispano-Filipino e Americano, em Brasília, teve tal aceitação que foi escolhido para representar o Brasil no Congresso Internacional de Municípios realizado em fevereiro de 1967 em Bangkok (Tailândia). Como representante do Brasil nesse evento, a cidade de São Caetano do Sul foi a única a colocar em discussão um programa educacional.

Segundo o plano, um sistema educacional comunitário era abordado a partir de quatro grandes divisões: Grupo A - Funções educacionais dirigidas à criança; Grupo B - Funções educacionais dirigidas ao adolescente; Grupo C - Funções educacionais dirigidas ao adulto; Grupo D - Funções educacionais dirigidas à comunidade como um todo.

Foram estabelecidas metas e sugestões de ações específicas para cada grupo. Com relação aos grupos A, B e C, foram abordados os problemas "clássicos" da área educacional (construções de escolas, formação básica, formação profissionalizante, desenvolvimento do ensino médio, formação universitária e pósuniversitária, especializações etc.).

No caso do ensino pré-primário e primário, por exemplo, foi elaborado, um planejamento para construção de escolas em todos os 15 bairros da cidade 
considerando que os alunos do pré-primário não poderiam andar mais que trezentos metros até a escola, e os do primário, quinhentos metros. (GARBELOTTO, 1967) Com a implantação desse planejamento, os resultados não demoraram a aparecer, e o número de vagas nas escolas passou de três mil para dezessete mil no período entre 1965 e 1968.

O Plano Educacional indicava a necessidade do aumento da oferta dos cursos ginasial e médio, principalmente os que proporcionassem ao lado do ensino básico uma formação profissional. Ainda segundo o Plano, a fragilidade da cidade era a falta de cursos universitários, o que obrigava os jovens a irem buscar essa formação em outras localidades ou estados. Apesar de se reconhecer a importância do ensino das humanidades, foi dada prioridade à instalação de faculdades que oferecessem uma formação voltada às demandas das empresas locais por mão de obra especializada. O mesmo valeu para os cursos profissionalizantes nos níveis ginasial e médio.

Além da cessão de um terreno para a instalação da Escola de Engenharia do Instituto Mauá foram implantadas três faculdades municipais: a Faculdade de Serviços Sociais; a Escola Superior de Administração de Negócios e a Faculdade Municipal de Ciências Econômicas, Políticas e Sociais. As duas últimas foram fundidas posteriormente, dando origem ao Instituto Municipal de Ensino Superior $(\mathrm{IMES})^{27}$.

O plano educacional também contemplava os adultos que já estavam fora do circuito escolar. Para esse segmento foi implantado o COPI (Cursos de Orientação Prático-Industrial), que oferecia à camada operária um curso rápido de especialização.

Provando sua abrangência, o plano também indicava que as necessidades das pessoas com deficiência ${ }^{28}$ deveriam ser assistidas, o que levou à construção de um prédio para o atendimento desse público, observando métodos pedagógicos e médicos, e que posteriormente viria a abrigar a Fundação Municipal Anne Sullivan, pioneira na América Latina no atendimento a surdocegueira. Pode-se citar também a

\footnotetext{
${ }^{27}$ Atual Universidade de São Caetano do Sul (USCS).

28 "Pessoas com deficiência são aquelas que têm impedimentos de longo prazo de natureza física, mental, intelectual ou sensorial, os quais, em interação com diversas barreiras, podem obstruir sua participação plena e efetiva na sociedade em igualdades de condições com as demais pessoas". Convenção das Nações Unidas sobre o direito das pessoas com deficiência. (PCD Mais, 2021)
} 
instalação de um Ginásio Vocacional, a criação do Curso Municipal de Línguas e a criação de uma Biblioteca Pedagógica.

Não obstante a importância das ações supracitadas, vamos centrar nossa análise no quarto grupo abordado no Plano Educacional, que interessa mais de perto ao nosso estudo. É através dele que há uma abertura de visão da administração municipal para o desenvolvimento de ações culturais de base para a cidade.

Como já observamos anteriormente, o Grupo D estava vinculado às funções educacionais dirigidas à comunidade, isto é, ações relacionadas à educação para o desenvolvimento da comunidade. Em relação a isso, observou-se que as Leis de Diretrizes e Bases da Educação Nacional da época eram omissas sobre essa questão.

Queremos agora estranhar o absoluto silêncio da lei quanto ao problema da
Educação Popular, isto é, educação que o poder público deve proporcionar
às camadas populares, fora da escola. (...) Pois, se o Brasil possui setenta
milhões de habitantes, e apenas oito milhões se encontram nas escolas
(primárias, média e superior), precisa, iniludivelmente, fazer alguma coisa
pela educação desses sessenta e dois milhões que não vão à escola.
(PREFEITURA, 1967b, p. 11)

Mas o mais interessante é como o plano educacional descreve o que era então essa educação do povo que "inclui sua compreensão da arte e do belo, através de bem selecionados, programas de música, de teatro, de dança, de exposições de pintura, dinamização de museus" (PREFEITURA, 1967b).

Quando se fala em educação e mais particularmente em obra educacional a primeira ideia é Escola. Entretanto Escola não é tudo, porque não são todos que as frequentam. Adultos, normalmente não frequentam as escolas. São as donas de casas, são os pais de famílias, que embora não tenham tido na mocidade a oportunidade para frequentar o Grupo Escolar ou Ginásio ou demais cursos, mas que, nem por isso, deixam de ter o mesmo direito e o mesmo interesse de ter mais conhecimento e mais instrução.

Para esses, que são milhares, a Prefeitura Municipal de São Caetano do Sul, sempre procurou através de promoções diversas, oferecer meios de adquirir cultura e conhecimentos, sem obrigá-los a sentar quietinhos em bancos escolares.

Essa preocupação em alimentar a cultura popular, levou a Prefeitura Municipal a patrocinar espetáculos de arte, tais como TUCAS, Noite de Poesia, concertos sinfônicos, peças teatrais de autores clássicos e consagrados, espetáculos de ballet, dança clássica, conferências e palestras sobre assuntos de interesse do momento. (PREFEITURA, 1967c, p. 16) 
Fica claro aqui que esse plano educacional trouxe não somente avanços na educação formal da cidade, mas também deu base para a implantação de uma política cultural no município. Sobre esta, Oscar Garbelotto relata:

Na época eu já entendia muito de cultura, então eu queria atuar em tudo. $\mathrm{Na}$ cultura, nós tínhamos muitas coisas diversificadas, a Escola de Balé, por exemplo, nós criamos também.

O que podíamos fazer de política cultural era patrocinar teatro, teatro infantil. Fizemos um contrato com o SESI e todo o mês eles preparavam um teatro especial, gratuito e distribuíam [ingressos] nas fábricas. E enchia a casa. Era sempre o grupo do Ulisses Cruz. Ele tinha um grupo teatral interessante. Não era um grupo altamente profissional, mas era um grupo interessante. Passava sempre algumas peças bem ao nível do pessoal que ia assistir. Era assim um pessoal mais simples e acabavam gostando muito das peças. (...). Eram feitas ali no [teatro] Santos Dumont, era o único que tinha. A gente passava uma vez por mês, custava uma fortuna. O SESI que patrocinava. (GARBELOTTO, 2018)

Em realidade, a preocupação com o desenvolvimento das artes perpassava por todo o plano educacional, que previa que em todos os níveis educacionais também fossem contemplados programas de formação artística e cultural, e que inspirou novas instituições que funcionariam paralelamente às escolas, como a criação do Curso Municipal de Ballet (atual Escola Municipal de Bailados) e da Fundação das Artes, uma "entidade-síntese do conjunto de obras e realizações, encetadas pela Administração Braido nos âmbitos educacional e cultural" (CARVALHO, 2018).

Como aponta José de Souza Martins, todo esse projeto educativo-cultural desenvolvido pelo poder público vinha ao encontro de outra ordem de demandas sociais:

Como a mais-valia é o produto morto do trabalho vivo, os estudiosos fetichizam a produção econômica e ignoram a produção social e a própria vitalidade do processo de reprodução social. Não compreendem, como sugere Henri Lefebvre, que a reprodução ampliada do capital é também reprodução ampliada de contradições sociais. É, portanto, condição do vivido, da práxis e da transformação. Esquecem que o capitalismo não é apenas a classe trabalhadora privada da mais-valia. O próprio capital tem que abrir mão de uma parte dessa mais valia em face das lutas sociais que dela pedem o retorno sob a forma de benefícios sociais e não simplisticamente de salários. A cidade e a sua monumentalidade e o modo de vida urbano são parte desses benefícios extra-salariais: na arte, nos museus, nos teatros, nos concertos, nas bibliotecas, nas universidades, nos recursos do espairecimento etc.

Os trabalhadores não apenas trabalham, mas vivem, vivenciam as consequências e possibilidades sociais do trabalho. A grande luta dos trabalhadores do subúrbio no último meio século foi muito mais por cultura e educação do que por salário. $E$ isso poucos notaram. $O A B C$, e também a 
região de Osasco e Guarulhos, sofreu uma verdadeira revolução cultural. Não só as escolas de primeiro e segundo graus de bom nível se disseminaram como também se disseminaram as escolas de terceiro grau, tudo majoritariamente com dinheiro público. Disseminaram-se os teatros, alguns dos melhores teatros da região metropolitana de São Paulo, como o de Santo André, projetado por Rino Levi. Tudo resultado de demanda popular. Em São Caetano, a Fundação das Artes é uma referência nacional e tem contribuído significativamente na formação de artistas, da música à pintura, mesmo oriundos de outras regiões. Porque para o militante profissional e estreito de hoje não passa pela cabeça, como não passava pela cabeça das elites do século XVIII, que o trabalhador já não está condenado ao trabalho manual. A grande libertação social que o subúrbio viveu intensamente, a grande emancipação, foi relativa à reconquista da competência criativa do trabalho intelectual, que a industrialização capitalista havia separado do trabalho manual. A reconquista não se deu, obviamente, na fábrica, no espaço do produzir, e sim nas lutas sociais da classe trabalhadora, no espaço do morar e do viver, como legado dos mais velhos a seus filhos e netos. (MARTINS, 2008, pp. 53-54)

Depois de discorrer sobre a trajetória de São Caetano do Sul e a gestão municipal na década de 1960, vamos retomar a discussão sobre o cenário cultural da cidade e da região nesse período para compreendermos mais claramente os movimentos que levaram à criação dos Salões de Arte Contemporânea e plantaram a ideia de museu de arte na cidade.

A partir da década de 1950, já se podia observar um panorama cultural com certa autonomia no $\mathrm{ABC}$, acompanhando o crescimento populacional e econômico da região. Da mesma forma que observamos em São Caetano do Sul, era exigida das administrações públicas uma resposta no sentido de implantar novos programas e redimensionar a infraestrutura e os equipamentos públicos. Essas ações se tornaram possíveis graças ao aumento de arrecadação das cidades (REIS, 2009).

Nesse quadro favorável, a cultura ganhou espaço com atividades de teatro, música, literatura, artes plásticas, fotografia e cinema. Como vimos anteriormente, foi esse o pano de fundo da Associação Cultural e Artística de São Caetano do Sul (ACASCS). Sendo uma produtora e difusora das manifestações culturais na cidade, veremos como ela teve um papel fundamental no desenvolvimento das artes plásticas e especialmente na criação dos salões de arte.

Ao focarmos as ações da ACASCS, devemos lembrar que elas eram realizadas por pessoas, e aqui vale destacar alguns personagens, daqueles que são instrumentos que movem as rodas dos acontecimentos e que serão centrais para a compreensão de nosso objeto de estudo. O primeiro deles é Sinval Correia Soares, diretor do departamento de Pintura e Escultura da ACASCS. Nascido na Bahia, desde a infância mostrou inclinação para desenho e pintura. Após sua chegada em 
São Caetano do Sul em 1952, estudou pintura com vários professores, entre eles Ana Guerreiro Schultz, com quem começou a produzir suas primeiras obras. Ingressou na Associação Paulista de Belas-Artes ${ }^{29}$, participou de mostras coletivas em São Paulo e vendeu sua primeira obra na Galeria Astréia ${ }^{30}$. Tal participação no movimento artístico da capital levou-o à convivência com artistas como Arnaldo Ferrari e o Grupo Santa Helena - Alfredo Volpi, Francisco Rebolo e Mário Zanini.

Sua primeira participação na ACASCS se deu em 1962, no 1ํ Salão de Artes Plásticas, realizado no saguão do Edifício Vitória ${ }^{31}$. Também participou do salão outro artista baiano radicado em São Caetano do Sul, o escultor Agenor Francisco dos Santos $^{32}$, que se tornou bastante ativo nas ações da ACASCS. ${ }^{33}$ No ano seguinte, já como diretor do Departamento de Pintura e Escultura, Sinval começou a dinamizar o setor através da programação de exposições com artistas de São Paulo e da abertura de um curso de "Desenho Artístico e Pintura". No mesmo ano, recebeu menção honrosa no $12^{\circ}$ Salão de Artes Modernas de São Paulo ${ }^{34}$. Sinval também era o responsável pelos cenários das peças encenadas pelo Departamento de Teatro. Conhecido por seus quadros retratando o nordeste, já se percebia em sua obra um caminho que o levaria à abstração, além de ter sido autor de grandes murais, destacando-se o que está instalado na fachada do jornal Diário do Grande ABC, em Santo André.

Informa-nos ainda Sinval que pleiteou junto à diretoria da Associação para que solicitasse da Prefeitura a organização de um Salão Oficial de Artes

${ }^{29}$ A Associação Paulista de Belas Artes (APBA) foi criada em 1942 com objetivo de propagar o ensino de arte e era responsável pela realização do Salão Paulista de Belas-Artes. Ao longo de sua história, congregou uma gama incontável de artistas como Mário Zanini, Alfredo Volpi, Fúlvio Pennacchi, Anita Malfatti, Fang, Luiz Sacilotto e Mario Grassmann, entre tantos outros (NOSSA..., 2019).

${ }^{30}$ A Galeria Astréia foi inaugurada em 1961 e se destacou por trabalhar com nomes consagrados da arte moderna como Portinari, Di Cavalcanti, Aldo Bonadei e outros. Encerrou suas atividades em 1980. (FIORAVANTE, 2001)

${ }^{31}$ O Prédio Vitória, foi por muitos anos um dos principais edifícios da cidade. Inaugurado em 1953, juntamente com o cinema de mesmo nome que funcionava no térreo, este local foi o "paço municipal" da cidade desde o início de seu funcionamento até 1961, abrigando as instalações da Prefeitura Municipal, da Câmara Municipal e do Fórum Municipal.

${ }^{32}$ Agenor Francisco dos Santos (1932-?) nasceu em Alagoinhas_(Bahia). Escultor autodidata tinha a madeira seu principal suporte. Radicou-se em São Caetano do Sul na década de 1960, onde produziu diversas obras públicas como a Estátua de São Pedro, A Família e a Mãe Preta, sendo esta última a única existente.

33 "Expuseram nesta mostra de São Caetano Sinval com pintura e Agenor apresentando escultura em madeira. Esta mostra deu grande popularidade aos expositores pelo fator da novidade e do não conhecimento por parte da nossa população de que em nosso município tínhamos elementos de tão alto quilate" (SINVAL, 1964, 1)

${ }_{34}$ O Salão Paulista de Arte Moderna foi criado pela Lei Estadual no 978/51. A partir de 1969, passou a chamar-se Salão Paulista de Arte Contemporânea. (ENCICLOPÉDIA ITAÚ CULTURAL, 2018) 
Plásticas que possibilitaria a realização de promoções de âmbito estadual. (SINVAL, 1964, p. 1)

Ainda em 1964, dois eventos do agora denominado Departamento de Artes Plásticas da ACASCS, que constaram da programação dos festejos de aniversário da cidade, chamaram a nossa atenção: o primeiro foi uma palestra proferida pelo Prof. Dr. Walter Zanini com o título "As Fontes da Arte Contemporânea”.

Realizou-se no dia 14/10, à noite, no salão de festas da ACASCS, uma conferência sobre a origem da Arte Contemporânea, proferida pelo professor Dr. Walter Zanini, diretor do Museu de Arte Contemporânea da Universidade de São Paulo.

Dr. Walter Zanini, que é uma das mais expressivas figuras entre os estudiosos da arte e dos artistas, profundo conhecedor do assunto, um dos mais eruditos professores, dissertou sobre diversos artistas como Boccioni, Cézanne, Gauguin, Kandinsky, Manet, Monet, Matisse, Munch, Picasso, Rodin, Toulouse-Lautrec, Van Gogh, Wlaminch (sic) e outros.

A uma boa plateia, o conferencista falou mais ou menos duas horas, conseguindo dos presentes efusivos aplausos pela sua brilhante dissertação. (CONFERÊNCIA..., 1964, p. 3)

Não foi possível precisar como Walter Zanini chegou à ACASCS, mas tudo leva a crer que esse fato esteja ligado ao programa de divulgação e difusão cultural implantado desde abertura do Museu de Arte Contemporânea da Universidade de São Paulo em 1963. Com o intuito de difundir a arte contemporânea democratizar o acesso à arte, foi realizado entre 1963 e 1978 um projeto contínuo de exposições itinerantes acompanhadas por palestras proferidas por intelectuais como Mario Schenberg, Alexandre Wolner, Aracy Amaral, entre outros, além do próprio Zanini. A proposta era "favorecer a penetração rítmica da arte em meios distantes dos grandes centros de cultura". Essas exposições circularam por vários estados, mas tiveram um maior alcance no interior de São Paulo (FREIRE, 2013, p.59). Temos notícias de que pelo menos duas dessas mostras foram trazidas para São Caetano do Sul ${ }^{35}$

O segundo evento foi a Exposição de Arte Contemporânea, inaugurada em 11 de outubro no saguão superior do Cine Vitória, contando com a participação de

${ }^{35}$ Segundo a publicação Walter Zanini Escrituras Críticas, organizada por Cristina Freire, a primeira mostra trazida a São Caetano do Sul foi 50 Desenhos e Guaches de Di Cavalcanti, que itinerou de julho de 1964 a junho de 1978, mas não consta nenhuma informação sobre a data ou local onde ela teria acontecido. A segunda mostra foi Quarenta gravuras Nacionais e Estrangeiras que trazia obras de artistas como Pierre Alechinsky, Maria Bonomi, Regina Silveira, Lívio Abramo, Leonard Baskin, Marc Chagall, Pablo Picasso, Giorgio Morandi, Oswaldo Goeldi, Marcelo Grassmann, entre outros, e também contou com palestras. Segundo esse registro, a mostra esteve em São Caetano entre os dias 8 e 15 de abril de 1969, no Centro Acadêmico da Escola de Engenharia "Mauá". (FREIRE, 2013, p.402-406) 
artistas de São Paulo e de outros estados, além dos representantes locais. Eram eles: Alberto Aliberti (escultura) ${ }^{36}$, Bernard Leduc (cerâmica decorativa), Jayme da Costa Patrão (cerâmica artística) ${ }^{37}$, Joel M. Linck (desenho), Nelson Sotto Maior (pintura) $^{38}$, Paco Romero (pintura) $)^{39}$ e Sinval Correia Soares (pintura e escultura) ${ }^{40}$.

Apesar de a inauguração ter ocorrido três dias antes da palestra, acreditamos que possa ter havido alguma interlocução anterior entre os organizadores e o professor Zanini que tenha influenciado numa certa atualização dos termos que vinham sendo adotados como "arte contemporânea". Quando essa mostra foi anunciada, em maio de 1964, ela era denominada "Salão de Arte Moderna" e contaria somente com artistas da cidade. Pode parecer um detalhe sem importância, mas acreditamos que isso tenha uma profunda relevância para a trajetória do colecionismo público que estamos analisando.

Essa interlocução teve certa continuidade, pois em 1965, o ACASCS Jornal noticiou uma visita de artistas e alunos da associação ao MAC-USP, onde foram atendidos pelo próprio professor Zanini, que "serviu de monitor ao grupo numa verdadeira aula sobre artes plásticas." Depois, o grupo se encaminhou a uma mostra de Arnaldo Ferrari que estava expondo "arte geométrica abstrata num dos salões da Rua Augusta." Nos festejos desse ano, foi realizada uma nova exposição de artes plásticas no saguão do Cine Vitória e uma palestra do professor Théon Spanudis também sobre a conceituação da arte contemporânea.

O segundo personagem que destacamos é Milton Andrade, que teve uma participação marcante nos movimentos ligados à cultura em São Caetano do Sul.

\footnotetext{
${ }^{36}$ Alberto Aliberti (1935-1994) estudou pintura com Joel M. Link e escultura com Féjer, entre 1960 e 1962. Em 1963, atua como presidente-fundador da Associação de Artes Visuais Novas Tendências, cujo objetivo é rearticular o grupo de artistas concretos ativos na década de 1950 em São Paulo. Ele também participou da mostra Seis Pesquisadores de Arte Visual, de 1966, uma das exposições itinerantes do MAC-USP. Além das atividades em arte, ocupa vários cargos no setor industrial e empresarial da cidade, à frente das Indústrias Aliberti e como sócio da empresa PAN (Produtos Alimentícios Nacionais), fabricante dos Chocolates Pan. (ENCICLOPÉDIA ITAÚ CULTURAL, 2017).

37 Jayme da Costa Patrão (1917-2004) nasceu na capital paulista, mudou-se para São Caetano em 1924. Trabalhou na Fábrica de Louças Adelinas, onde ingressou em 1932 como desenhista, e, depois, até 1950, como chefe do setor artístico. Posteriormente, instalou a sua própria empresa de decoração de cerâmica - Cerâmica Artística da Costa. Atuou no Movimento Autonomista, suas charges ficaram famosas com o personagem Zé Caetano. Teve importante atuação também no teatro amador, dirigindo diversas peças na ACASCS e no grupo $A$ turma. Fez parte do Conselho Diretor da Fundação Pró-Memória desde a criação da mesma.

${ }^{38}$ Nelson Sotto Maior foi o primeiro diretor do Departamento de Artes Plásticas da ACASCS.

${ }^{39}$ Não conseguimos maiores informações sobre Joel M. Linck, Bernard Leduc ou Paco Romero.

40 Sinval Correia Soares (1927-2011) frequentou a Associação Paulista de Belas-Artes entre 1956 e 1957. Em 1961, retornou a esta instituição sob a orientação da professora Ana Guerreiro Schultz, quando começou a afirmar-se no campo criativo do expressionismo. Em 1967, destacou-se na IX Bienal Internacional de São Paulo. Era amigo do artista Arnaldo Ferrari.
} 
Nascido em Itapira, interior de São Paulo, bacharelou-se em Direito pela Pontifícia Universidade Católica de Campinas, onde estudou com Oscar Garbelotto. Andrade sempre foi um "homem de teatro" e, durante seu período de faculdade, comandou o TUC - Teatro Universitário de Campinas. José Armando Pereira da Silva, outro amigo da faculdade, deixou a seguinte narrativa sobre o período.

Cheguei ao ABC em 1963, vindo do interior de São Paulo - Itapira. O Milton já estava aqui na época. Nós éramos formados na mesma faculdade. Fizemos a mesma faculdade em Campinas, só que o Milton estava uns dois anos na minha frente. E lá a gente já era muito amigo, não só por sermos conterrâneos, mas [por] termos os mesmos interesses. A gente acabou se interessando pela área de teatro. O Milton comandou o Teatro Universitário de Campinas, o TUC. Montou algumas peças lá. E na época a gente também, o Milton e eu, tivemos contato com o Grupo Vanguarda de Campinas, que era um grupo de artistas plásticos. Um dos artistas plásticos desse grupo inclusive que fez os cenários para as peças do Teatro Universitário. Então a gente já tinha essa ligação com o pessoal de artes plásticas desde essa época. (SILVA, 2019)

Em 1961, Andrade, com apenas 24 anos, mudou-se para São Caetano do Sul, para chefiar o setor de relações públicas da ZF - Fábrica de Engrenagens S/A. É interessante ressaltar que a influência que Andrade trouxe do movimento artístico de Campinas também chegou à região do $A B C$ através de José Armando Pereira da Silva, que organizou em 1963 uma grande mostra do Grupo Vanguarda no Salão Nobre da Biblioteca Municipal de Santo André, causando grande impacto no meio artístico local. No final de seu primeiro ano em São Caetano, Milton Andrade conheceu a ACASCS e logo se tornou um associado.

Lá na CIESP, conheci uma pessoa maravilhosa, e me arrependo até o
fundo da alma de não ter feito o que vocês estão fazendo aqui: gravar um
depoimento, com Matheus Constantino ${ }^{41}$, que tinha feito teatro amador em
São Caetano, ainda em italiano, para a grande família italiana de São
Caetano. E o Mateus me contava essas coisas todas. Perguntou-me: Você
gosta de teatro? Então vá ao ACASCS! E aí, uma noite fui. O Mário Dal'Mas
era o presidente lá. Fui com minha mulher, nós éramos recém-casados. A
ACASCS tinha um salão muito bonito. Nem sei o que é hoje. Tinha um
salão muito bem montado, com cadeiras feitas especialmente, em forma de
lira, cortinas muito bonitas, tinha um barzinho bem montado. Aí me sentei,
veio um garçom, um senhor muito simpático, um velhinho e eu perguntei:
"Vocês têm teatro?" "Temos sim." E ele já puxou uma cadeira e se sentou.
Este homem tinha sido palhaço de circo, chamava-se Pedro Pardo Oller, e
era ele uma das pessoas que dirigia peças de teatro na ACASCS. A última
informação que tive dele é que haveria uma reunião na manhã seguinte.
"Apareça aí".

${ }^{41}$ Matheus Constantino (1891-1979) nasceu na Catânia, capital da Sicília (Itália), e chegou ao Brasil com 2 anos de idade. Aos 15, mudou-se para São Caetano onde se tornou um industrial. Foi um dos precursores do teatro amador no São Caetano Esporte Clube na década de 1920. Participou dos dois movimentos autonomistas (o de 1928 e o de 1946). Além disso, foi um dos fundadores da Associação Cultural e Artística de São Caetano do Sul (ACASCS). 
E eu apareci na reunião e ele apresentou o pessoal e disse: "Aqui está o... Como é mesmo o seu nome?" "É Milton." "Aqui está o Milton, que vai dirigir a nossa próxima peça." Ele já tinha escolhido o elenco, já tinha selecionado o texto, que era A Ceia dos Cardeais, e eu dirigi a primeira peça na ACASCS.

A ACASCS já tinha um trabalho de teatro bastante intenso, orientado pelo Jayme da Costa Patrão, que está aqui, pelo Pedro Oller e pelo Carlos Rivani e eu entrei para fazer parte desse time, exatamente. (MILTON..., 1999, p. 69) ${ }^{42}$

Esse foi o início de uma intensa atividade de Andrade frente ao Departamento de Teatro, sempre mantendo estreito contato com o pessoal que girava em torno do Departamento de Artes Plásticas (Sinval, Agenor, Alberto Aliberti, Jayme da Costa Patrão). Mesmo depois de deixar a ACASCS, continua muito atuante no cenário cultural da cidade, participando do grupo teatral independente chamado A Turma. No início da gestão Braido, recebeu o convite para assumir a seção de Cultura do recém-criado Departamento de Educação e Cultura da municipalidade.

Foi nesse contexto que, em três de novembro de 1966, Milton Andrade, Sinval Correia Soares, Arnaldo Ferrari, Jayme da Costa Patrão e Aluísio Domingo dos Santos enviaram uma correspondência ao Prefeito Municipal solicitando a criação de um salão oficial de arte contemporânea com premiações, que possibilitasse a formação de um acervo artístico e a criação de um museu de arte, retomando uma demanda que já havia sido dirigida pela diretoria da ACASCS três anos antes ao diretor do Departamento de Educação e Cultura, Oscar Garbelotto. Este último é o terceiro personagem que foi veículo dessa realização. Grande entusiasta das artes e empenhado no pleno funcionamento do DEPEC em suas duas dimensões de Educação e Cultura, ele abraçou o projeto apresentado.

Criado pela Lei no 1.560 de São Caetano do Sul de 27, de abril de 1967, e regulamentado pelo Decreto no 2.895 de 09, de junho de 1967, o Salão de Arte Contemporânea foi um dos primeiros salões do tipo a serem realizados no interior de São Paulo ${ }^{43}$. Segundo essa Lei, o Salão compreenderia quatro seções: Pintura, Escultura, Arte Gráfica e Arte Decorativa, seguindo a divisão de apresentação para a

\footnotetext{
${ }^{42}$ Não temos muitas informações sobre Pedro Pardo Oller e Carlos Rivani; sabemos apenas que ambos eram ligados ao Departamento de Teatro da ACASCS, sendo responsáveis pela direção dos espetáculos.

${ }^{43}$ O primeiro Salão Arte Contemporânea aconteceu em Campinas em 1965; os de Santo André e Piracicaba, em 1968. Em São Bernardo do Campo, na década de 1970, houve os Salões de Artes Plásticas promovidos pela Associação Bernardense de Belas-Artes, cujas obras premiadas ficavam para municipalidade. O Salão Paulista de Arte Contemporânea foi criado em 1969.
} 


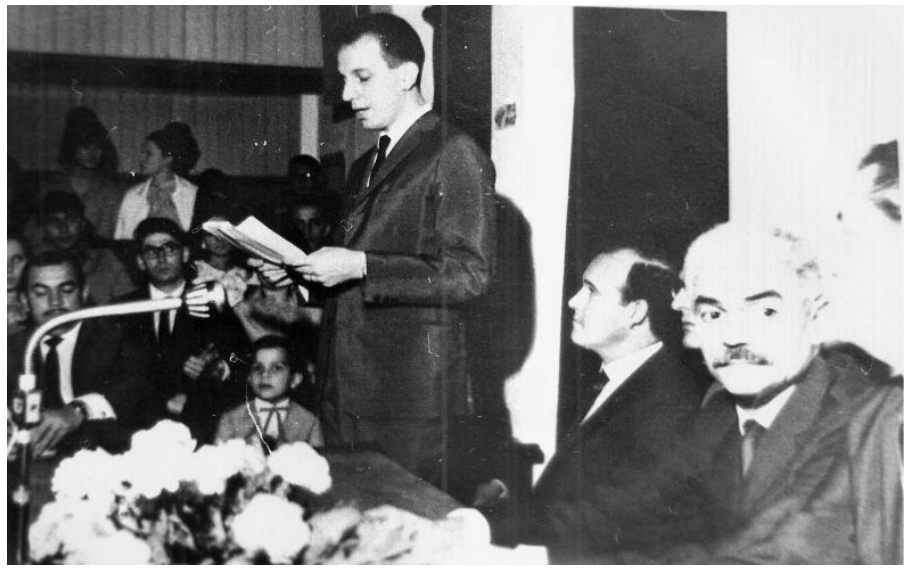

Figura 11 - Aluísio Domingos dos Santos com sua obra Mãe Preta, década de 1960.

Acervo Fundação Pró-Memória de São Caetano do Sul
Figura 10 - Milton Andrade, Oscar Garbelotto e Mário Dall'Mas, década de 1960. Acervo Fundação Pró-Memória de São Caetano do Sul

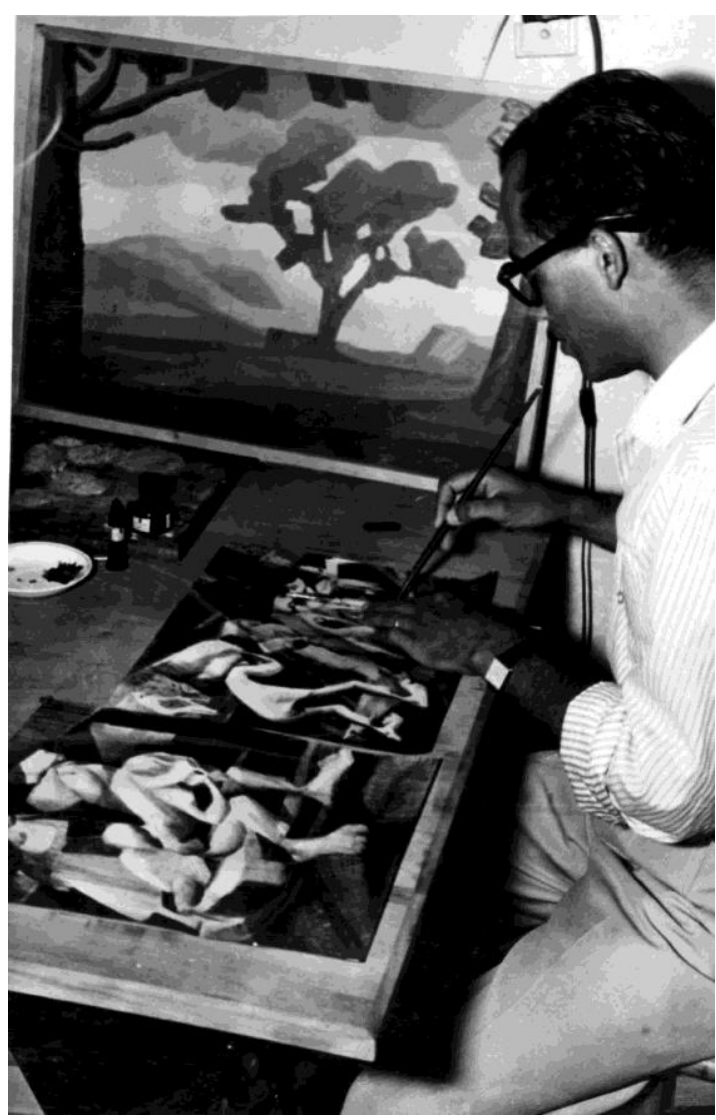

Figura 12 - Sinval Correia Soares em seu ateliê, década de 1960 .

Acervo Fundação Pró-Memória de São Caetano do Sul 
Arte Moderna consagrada pelo MoMA. ${ }^{44}$ Ficou também expresso que os trabalhos premiados passariam a fazer parte do acervo municipal.

Tinha que ser um negócio bem bolado. Fizemos um regulamento bem "boladinho", com prêmios muito bons, prêmio aquisitivo, quem ganhava deixava a obra lá. E convidamos alguns iluminados de São Paulo para julgar os quadros. Tudo gente de peso. E fizemos o salão, o primeiro, e acabou sendo um sucesso muito grande.

Vieram muitos artistas de nível nacional. A repercussão foi muito grande. $O$ que nos animou a fazer o segundo. (GARBELOTTO, 2018)

O I Salão de Arte Contemporânea de São Caetano foi realizado de $1^{\circ}$ de julho a 30 de agosto, como parte dos festejos de aniversário da cidade. Seu sucesso estimulou a realização do segundo, em 1968, que fez parte do Mês da Cultura realizado no Colégio Dona Idalina Macedo Costa Sodré, onde também foram realizados o I Salão de Arte Fotográfica, a II Feira do Livro e o I Festival Nacional de Música Contemporânea de Autores Brasileiros.

A partir de 1969, com Milton Andrade como diretor da Fundação das Artes ${ }^{45}$, esta passou a ser responsável pela realização dos salões. Eles foram realizados anualmente, com exceção dos anos de 1972 e 1976, até 1979. Abriu-se um grande hiato, principalmente depois da saída de Andrade da Fundação das Artes em 1983 e das mudanças de sua direção. Em 1988, foi realizado o XI Salão, mas já sem a mesma representatividade dos anteriores. ${ }^{46}$

Depois da realização desse salão, não houve novas iniciativas para continuidade dos mesmos e as obras adquiridas pelos prêmios-aquisição ficaram sem um destino conhecido. Algumas delas por um tempo decoraram as paredes da Prefeitura Municipal, mas depois saíram de circulação.

O final da década de 1980 traria ao ABC um movimento de "emergência da memória como uma das preocupações culturais e políticas das sociedades

44 O Museu de Arte Moderna de Nova York (MoMA) tem como um dos princípios de sua missão institucional o reconhecimento de que "a arte moderna e contemporânea transcende os limites nacionais e envolve todas as formas de expressão visual, incluindo pintura, escultura, desenhos, impressões e livros ilustrados, fotografia, arquitetura e projeto, e filme e vídeo, assim como novas formas ainda a serem desenvolvidas ou compreendidas, que reflitam e explorem as questões artísticas da era. (MUSEUM, 2019, tradução nossa). No original: "That modern and contemporary art transcend national boundaries and involve all forms of visual expression, including painting and sculpture, drawings, prints and illustrated books, photography, architecture and design, and film and video, as well as new forms yet to be developed or understood, that reflect and explore the artistic issues of the era".

${ }^{45}$ Milton Andrade foi diretor da Fundação das Artes de 1969 a 1983.

${ }^{46}$ A Secretaria de Cultura do Município tentou organizar um novo salão em 2012, mas sem resultados e continuidade. 
ocidentais" (HUYSSEN, 2004, p. 9). Tal emergência da memória é notável não somente em São Caetano do Sul, mas em toda região do Grande ABC, podendo-se observar esse fenômeno em duas esferas: a pública e a privada.

Na primeira, no bojo dos movimentos deflagrados pelos metalúrgicos no final da década de 1970, verificamos o nascimento de um movimento coletivo dedicado à memória regional, o GIPEM - Grupo Independente de Pesquisadores do Grande ABC (MEDICI, 1992). Esse movimento, organizado a partir de 1987, reuniu sindicalistas, memorialistas, professores e uma gama bastante heterogênea de pessoas que de alguma maneira simpatizavam com a causa, deflagrando diversas ações nos sete municípios que compõem a região do Grande ABC. Através delas, pautou-se o reconhecimento da história e dos patrimônios locais, procurando mobilizar também poderes públicos. A primeira grande realização surgida dessas mobilizações foi o I Congresso de História do ABC, realizado em 1989, com apoio da Prefeitura Municipal de Santo André ${ }^{47}$. A partir daí, os poderes públicos municipais encamparam "a causa da memória”, com a estruturação de equipamentos públicos destinados à coleta, preservação e difusão de bens patrimoniais relativos à memória e à história locais, bem como o estímulo à produção de uma historiografia sobre a região ${ }^{48}$.

Huyssen aponta uma das chaves para compreensão desse fenômeno ao abordar a disseminação geográfica da cultura da memória, identificando na Argentina e no Chile tentativas de criação de esferas públicas de memória "real" contra "as políticas do esquecimento, promovidas pelos regimes pós-ditatoriais" (2004, p. 16). Podemos também identificar essas mesmas iniciativas nos movimentos pela memória do $A B C$, que tiveram suas ações na busca de um protagonismo histórico das camadas sociais antes consideradas apenas como coadjuvantes. É nesse sentido que José de Souza Martins desenvolve seu estudo sobre os subúrbios industriais.

\footnotetext{
${ }^{47}$ Desde então, os Congressos de História do ABC vêm ocorrendo de forma bienal em cada um dos sete municípios que compõem a Região do Grande $A B C$, numa parceria entre as prefeituras e a sociedade civil. O 15을 Congresso foi programado para 2019, na cidade de Santo André.

${ }^{48}$ Em Santo André, foi criado o Museu Histórico Dr. Octaviano Gaiarsa (1982); em São Bernardo do Campo foi criado o Serviço de Documentação da História Local em 1988 (hoje existe a Seção de Pesquisa e Documentação e a Seção de Patrimônio); em São Caetano do Sul, o Museu Histórico, que fora criado por José de Souza Martins em 1959, foi reaberto em 1977, a Revista Raízes começou a ser editada pela Prefeitura Municipal em 1989 e a Fundação Pró-Memória foi criada em 1991; em Diadema, foi criado o Centro de Memória (1993); em Mauá, o Museu Barão de Mauá (1982); e em Ribeirão Pires, o Museu Histórico Família Pires (1983).
} 
Na história local e cotidiana estão as circunstâncias da História. É nesse sentido que a história do subúrbio é uma história circunstancial. O que permite resgatá-la como História? A junção dos fragmentos da circunstância - quando a circunstância ganha sentido, o sentido que lhe dá a História. A história local não é uma história de protagonistas, mas de coadjuvantes. É nesse sentido, também, que a escala de tempo da história local não é a mesma escala dos grandes processos históricos. Por isso mesmo, os agentes e personagens da história local não podem captar imediatamente 0 significado histórico de suas ações, de seu trabalho e, até, de suas lutas. (MARTINS, 1992, p. 13)

Dessa maneira, "entender - e depois se fazer entender - que também uma região industrializada e operária tem o direito (e dever) de pensar as suas origens, a partir da visão do protagonista desta História", foi uma das bandeiras erguidas por esses movimentos (MEDICI 1992, p. 45).

Se a busca pelo protagonismo esteve no princípio dessa "era da memória no ABC", o forte processo de desindustrialização e globalização que se iniciou ainda na década de 1980 deu um novo fôlego à valorização do passado como uma âncora identitária da região. Encontramos também em Huyssen o respaldo para esta afirmação:

Quaisquer que possam ser as diferenças e especificidades locais das causas, elas sugerem que a globalização e a forte reavaliação do respectivo passado nacional, regional ou local deverão ser pensados juntos. Isto, por seu turno, faz perguntar se as culturas de memória contemporâneas em geral podem ser lidas como formações reativas à globalização da economia. (HUYSSEN, 2004, p. 17)

Concluindo esta questão, identificamos que o "medo do esquecimento", por mais dialético que possa se apresentar, é o ponto básico para a compreensão dos movimentos de memória no Grande $\mathrm{ABC}$, particularmente, em São Caetano do Sul. $^{49}$

A cidade criou a sua primeira instituição de preservação histórica em 1959, o Museu Municipal, organizado por José de Souza Martins, na época apenas recémformado no curso de magistério. Tal instituição teve pouca duração, devido às mudanças políticas, sendo reaberta somente em 1977 (ano da comemoração do centenário da imigração italiana). Como reflexo de movimentação pela memória nos

49 "É o medo do esquecimento que dispara o desejo de lembrar ou é, talvez, o contrário? É possível que o excesso de memória nessa cultura saturada de mídia crie uma tal sobrecarga que o próprio sistema de memórias fique em perigo constante de implosão, disparando, portanto, o medo do esquecimento? Qualquer que seja a resposta para estas questões, fica claro que velhas abordagens sociológicas da memória coletiva - tal como a de Maurice Halbwachs, que pressupõe formações de memórias sociais e de grupos relativamente estáveis - não são adequadas na dinâmica atual da mídia e da temporalidade, da memória, do tempo vivido e do esquecimento" (Huyssen, 2004, p. 19). 
anos de 1980, a Fundação Pró-Memória começou a ser gestada (COMISSÃO, 1989), sendo efetivamente inaugurada em 1991.

Encabeçando o projeto que levou à criação da Fundação Pró-Memória encontraremos novamente Oscar Garbelotto. Naquele momento ele era Diretor de Assuntos Jurídicos da Prefeitura e, juntamente com Aleksandar Jovanovic (Diretor de Comunicação da Prefeitura Municipal), Sonia Maria Franco Xavier (diretora do Museu Histórico) e Mário Botteon (descendente dos primeiros imigrantes italianos), delineou os eixos de atuação da uma nova instituição que eram, além da incorporação do Museu Histórico à estrutura da Fundação Pró-Memória, a criação de um Serviço de Documentação e Pesquisa da História local. Fazia também parte desse plano inicial a criação de uma Pinacoteca para reunir o acervo de artes plásticas do Município.

O objetivo principal desse projeto era a criação de uma instituição que operacionalizasse a preservação do patrimônio histórico e cultural da cidade com um maior dinamismo. Para isso, tiveram como modelo duas instituições que, apesar de atuarem em âmbitos diferentes, ofereciam um modelo institucional compatível com o objetivo desejado.

A primeira foi a Fundação Nacional Pró-Memória (FNPM), órgão auxiliar da Secretaria do Patrimônio Artístico Nacional, responsável pela preservação do acervo cultural e paisagístico brasileiro; a segunda foi a Fundação Cultural de Blumenau, responsável pela conservação do patrimônio histórico e cultural da cidade. O que chamou a atenção da comissão responsável pelo projeto de São Caetano foi o fato dessas instituições se configurarem, como pessoas jurídicas de direito público ou privado $^{50} \mathrm{e}$, dessa forma, tinham mais autonomia do que um órgão da administração pública direta, o que lhes permitia a aquisição de recursos tanto por via de repasses orçamentários públicos quanto por doações de entidades públicas ou privadas, e que possibilitava maior liberdade de obtenção e gestão desses subsídios. Outro fator de interesse era a estrutura administrativa das instituições, composta de um presidente ou diretor, indicados pelos respectivos órgãos superiores ${ }^{51}$ e de um

\footnotetext{
${ }^{50}$ A Fundação Nacional Pró-memória era uma pessoa jurídica de direito privado, ao passo que a Fundação Cultural de Blumenau era uma pessoa jurídica de direito público.

${ }^{51}$ No caso da Fundação Nacional Pró-Memória, o presidente era designado pelo Presidente da República, já para a Fundação Cultural de Blumenau, a escolha do diretor cabia ao Prefeito Municipal.
} 
conselho curador, que abria a possibilidade da participação efetiva da sociedade civil, o que conferia uma segurança maior para a gestão dos bens culturais.

A Fundação Blumenau também foi uma inspiração pela amplitude de seu escopo de atuação. Esta instituição tinha sob sua responsabilidade a criação e gestão de museus, bibliotecas e arquivos e a realização de ações de difusão da história, cultura, patrimônio e história local, vinculadas a uma política editorial.

Assim, a Fundação Pró-Memória de São Caetano do Sul foi criada como entidade de direito público vinculada à Prefeitura Municipal e tendo como principal objetivo "criar, organizar, instalar e manter estabelecimento e atividades voltadas para a preservação, manutenção e divulgação do patrimônio histórico do Município" ${ }^{25}$. Seu primeiro presidente foi o próprio Oscar Garbelotto, e uma das primeiras ações da Pró-Memória foi incorporar o Museu Municipal, que na época era chamado de Museu Histórico da Imigração Italiana Oswaldo Samuel Massei. A edição da revista Raízes ${ }^{53}$ e dos livros dedicados à história e memória da cidade foi outra iniciativa da Prefeitura Municipal logo absorvida pela nova instituição.

O serviço de documentação ${ }^{54}$, previsto no projeto, foi inaugurado em 1993. Nesse mesmo ano, o acervo de obras dos salões foi encontrado em meio aos materiais do almoxarifado da Fundação das Artes, algumas obras inclusive eram usadas para forrar o chão do local. Imediatamente foi solicitado ao Prefeito que esse acervo fosse transferido para a Fundação Pró-Memória ${ }^{55}$, algo que somente se efetivou em 1994, quando as obras foram guardadas em um pequeno depósito nas instalações da Pró-Memória.

A criação da Pinacoteca dependia de espaço que pudesse abrigar mais um museu. A solução encontrada foi construção de um novo prédio ${ }^{56}$. O local escolhido, uma das esquinas da Praça do Professor, era próximo ao centro da cidade e ao lado de um equipamento cultural, o teatro Santos Dumont.

A construção deste prédio sofreu vários atrasos e mudanças de perfil e de uso. Assim, quando ele foi terminado em 2001, já não seria mais o prédio somente da Pinacoteca Municipal. O Departamento de Educação e Cultura havia encampado

\footnotetext{
${ }^{52}$ Lei 3.147, de 12 de junho de 1991.

${ }^{53}$ A revista Raízes é uma publicação semestral dedicada à difusão e incentivo a pesquisas referentes à história e memória locais.

${ }_{54}^{54}$ Hoje Centro de Documentação Histórica.

${ }_{56}^{55}$ Decreto no 7.009, de 08 de março de 1993.

56 O então prédio da Pinacoteca foi fora projetado pelo arquiteto Rodolfo Cesar de Paula, e suas obras começaram no início dos anos 1990, ainda na gestão do Prefeito Luiz Olinto Tortorello.
} 
o espaço e nele foi instalado o Complexo Educacional de Ensino Fundamental. Esse Complexo abrigaria a Biblioteca Municipal Paul Harris, a sede administrativa da Fundação Pró-Memória e, finalmente, seria criada a Pinacoteca Municipal, com um salão de exposições, reserva técnica e ateliê para atividades educativas.

Por volta de setembro de 2001, a Pró-Memória foi informada da finalização das obras do prédio e que o Complexo Educacional seria inaugurado no início do ano seguinte, e a ideia da criação do museu de arte, há tanto tempo adormecida, teve de ser retomada na velocidade da luz: as obras da coleção dos salões começaram a ser retiradas do depósito no qual estavam. Toda informação que se tinha sobre elas estava contida em uma listagem onde constava o salão do qual a obra tinha participado, o nome de um artista, um título e data. Grande parte das obras mantinha em seu verso as etiquetas que haviam sido coladas atrás delas com as informações básicas. Porém, algumas tinham apenas vestígios dessas etiquetas e outras não tinham nada. Iniciou-se então, um trabalho de reconhecimento e identificação das obras, onde a menor inscrição foi fundamental para o sucesso da empreitada. Outra tarefa urgente era a higienização e um diagnóstico básico dos danos que essas obras haviam sofrido ao longo de tantos anos de esquecimento dentro das instituições.
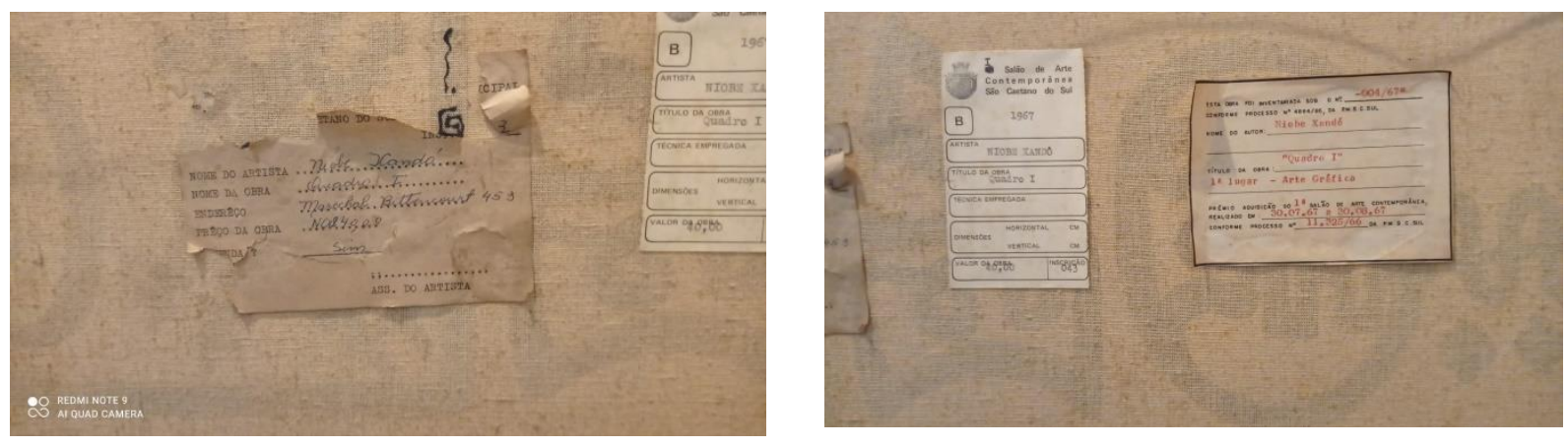

Figura 13 - Etiquetas coladas no verso da obra Quadro I de Niobe Xandó, premiada no I Salão de Arte Contemporânea, 1967 
A grande demanda daquele momento era a exposição inaugural da Pinacoteca, que não poderia ter outro tema que não a coleção dos salões, razão primeira da criação desse museu. Soubemos também que a coleção marcaria definitivamente a vocação da Pinacoteca Municipal - a arte contemporânea.

É importante ressaltar que até este momento, todas as equipes técnicas que trabalharam com esse acervo não tinham a ideia completa da narrativa que apresentamos neste capítulo. A documentação sobre esse acervo era inexistente naquele momento e ainda era incipiente quando iniciamos esta pesquisa.

A curadoria dessa exposição foi um grande desafio. Cerca de $40 \%$ das obras requeriam uma intervenção de restauro mais profunda, que não seria possível de ser realizada a tempo para a inauguração.

Mesmo com todas as dificuldades, em 18 de abril de 2002, a Pinacoteca Municipal foi inaugurada com a mostra Retrospectiva 2002: onze anos de salões de arte em São Caetano do Sul, que ficou aberta até junho de 2003. Um período tão longo se justificou pelo longo tempo que as obras ficaram "desaparecidas", longe do olhar do público. Nessa exposição foram apresentadas noventa e nove obras, das cento e trinta e cinco que compõem o acervo dos salões. Junto à mostra principal, foi trazida, numa parceria com o Museu de Arte Contemporânea da Universidade de São Paulo, a mostra Retrato e Autorretrato, um projeto da museóloga Amanda Tojal, dedicada ao público especial. Com a exposição paralela, procuramos marcar desde o início o papel importante da ação educativa dentro dos espaços museológicos, que deveria ser uma diretriz para a nova Pinacoteca.

Esse foi o momento do encontro da coleção com o seu museu. No próximo capítulo vamos aprofundar o olhar histórico sobre os salões de arte contemporânea de São Caetano e a composição da coleção em si. 


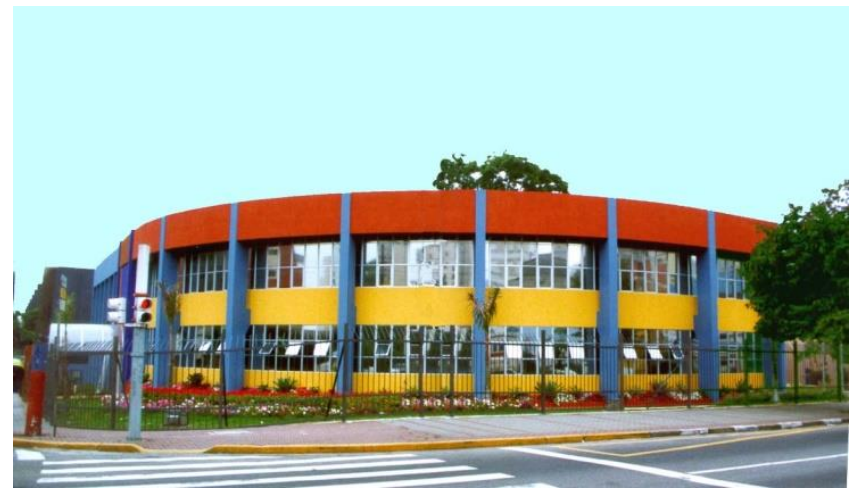

Figura 14 - Complexo Educacional do Ensino Fundamental, sede da

Fundação Pró-Memória e da

Pinacoteca Municipal, 2002

Acervo Fundação Pró-Memória de

São Caetano do Sul
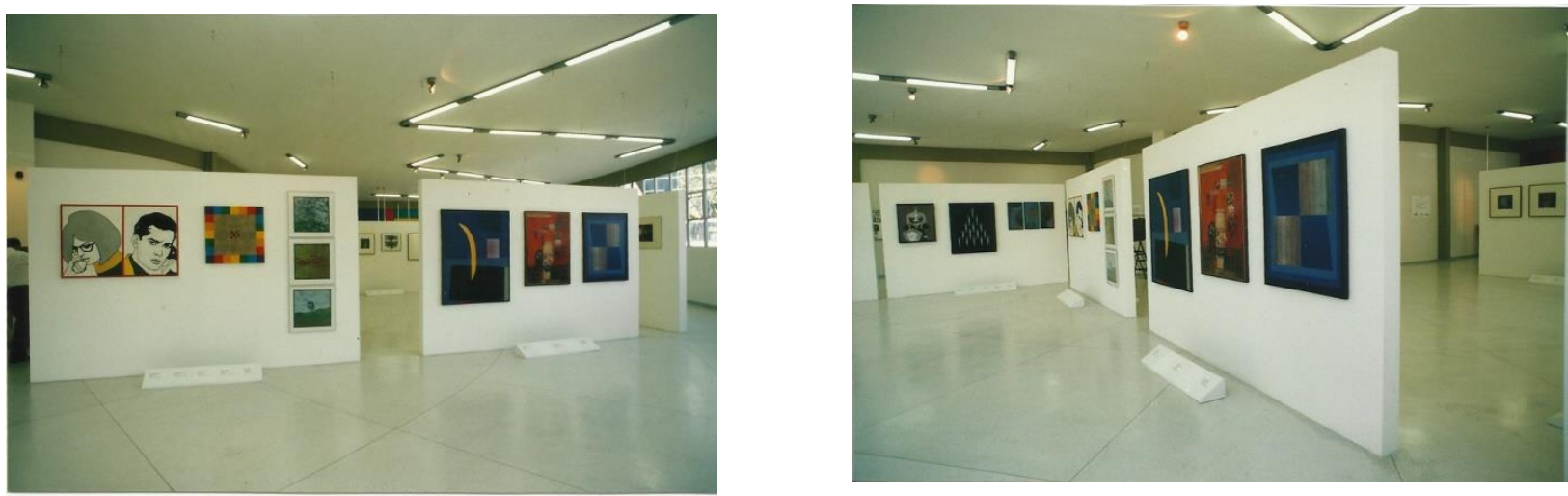

Figuras 15 e 16 - Exposição inaugural da Pinacoteca Municipal - Retrospectiva 2002 onze anos de Salões de Arte, 2002

Acervo Fundação Pró-Memória de São Caetano do Sul 


\title{
CAPÍTULO 2
}

\section{OS SALÕES EM QUESTÃO}

Emerson Dionísio, em seu estudo sobre diversos museus pelo Brasil, identificou um ponto crucial em nossa análise que pode fazer de nosso trabalho um ponto de referência para outras instituições.

\begin{abstract}
Os salões ligados a ou herdados pelos museus, no âmago de uma coalizão heterogênea de atores culturais e econômicos, desempenharam na história recente das instituições brasileiras um papel determinante na homologação e na hierarquização dos valores artísticos utilizados na construção dos acervos. Dos salões não saíram apenas obras assimiladas às coleções públicas, mas, também, atribuições, classificações, publicidade e interdições que afetaram parte considerável do circuito artístico doméstico, em uma função de qualificação dos criadores. Em muitos sentidos, por suas aquisições, pela apresentação das obras e pela organização dos discursos, os salões vêm conferindo visibilidade ampliada aos novos interesses dos agentes culturais sejam eles mercadológicos ou patrimoniais. (OLIVEIRA, 2010, p. 51)
\end{abstract}

Neste capítulo faremos uma análise dos salões de arte contemporânea partindo de uma breve contextualização desse tipo de evento que foi por muito tempo um dos principais tributários dos sistemas de arte. Não pretendemos aqui fazer uma retomada histórica exaustiva dos salões de arte, apenas tocar em alguns pontos sobre sua trajetória em nosso país que nos ajudem a refletir melhor sobre o significado dos salões que se realizaram em São Caetano do Sul.

Segundo Ângela Ancora da Luz, a "história dos salões se confunde com a história da arte" (LUZ, 2005, p. 19). Entendendo-os como um campo de "emulação entre artistas", cujos primeiros ensaios podem ser identificados no confronto vivido por Michelangelo Buonarotti e Leonardo da Vinci quando os dois são convidados por Pietro Soderini para pintar, cada um uma parede na Sala do Conselho do Palácio Municipal de Florença, que revela uma nova relação entre o artista com sua "liberdade de expressão" e o "surgimento do apreciador de arte que, potencialmente, seria também colecionador" (LUZ, 2005, pp. 25-26). A partir daí, torna-se cada vez mais importante para o artista ter um espaço para apresentar suas obras ao público que seria um comprador em potencial. Assim, surgem as mostras realizadas nas ruas e nas feiras onde os próprios artistas faziam as negociações. Com o nascimento das Academias de Arte em substituição às Corporações de Ofícios, novas diretrizes para o campo das artes são estabelecidas, assim como a prática de exposições regulares levadas a cabo por elas. 
Das exposições realizadas pela Academia Real de Pintura e Escultura da França entre 1725 e 1773, no Salon Carré, um espaço nobre no Louvre, nasceu a denominação dos eventos aqui tratados. "Esta grande sala passou a nomear por extensão, as mostras oficiais de grande repercussão: os salões." (LUZ, 2005, p. 35).

Desde esse início, já se podia identificar nos salões três atributos principais: primeiro, eles são veículo para o reconhecimento dos artistas; segundo, são espaços que conferem valor às obras e seus autores; e finalmente, são retratos da sociedade ao seu redor. Outro aspecto a ser ressaltado é o vínculo entre os salões e o nascimento da crítica de arte ${ }^{57}$.

Charles Baudelaire, escrevendo sobre o Salão de 1846, está mais interessado em questões como a cor, composta de massas que são feitas de uma infinidade de tons, ou com as linhas que dividem e delimitam estas massas. Isto a partir de obras, nas quais ele já não fica preso, apenas, ao que seus olhos veem, na descrição contemplativa que se associa ao próprio juízo de gosto, mas ele já propõe indagações no campo das conceituações que, mesmo partindo da obra, sinalizam uma diferente postura crítica, prenunciadora da modernidade.

Mas a construção de pensamento crítico não se restringiu a Diderot e Baudelaire. Nomes como Stendhal, Alfred de Musset, Eugène Fromentin ${ }_{2}$ Théophile Gautier, Émile Zola, Guy de Maupassant e, já no início do século $X X$, Guillaume Apollinaire, ajudaram a construir, na intimidade com as obras de arte, o novo texto que daria as coordenadas da moderna crítica de arte. (LUZ, 2005, pp. 42-43)

Em terras brasileiras, os salões terão a mesma origem: a real Academia de Desenho, Pintura, Escultura e Arquitetura Civil ${ }^{58}$. A partir de 1840, passou a ser realizada anualmente a Exposição Geral de Belas-Artes, com o objetivo de propiciar o desenvolvimento dos artistas da Academia, que se tornou o primeiro salão de artes oficial de nosso país.

Os salões oficiais de arte tiveram uma expressão cultural sem precedentes nos principais centros de produção artística no mundo, com seu apogeu nos séculos XVIII e XIX, notabilizando-se principalmente na França. Como nossa formação acadêmica está alicerçada no modelo francês, pela vinda da Missão Francesa ao Brasil, em 1816, ano em que na Academia é criada por Decreto de D. João VI, exposições em modelos semelhantes passaram a ser uma prática sistemática em nosso meio e, como bons iniciados, não

\footnotetext{
57 "Sobre o Salão de 1846, Baudelaire escreverá um texto em que irá afirmar o grande e terrível ponto de interrogação que está em poder da crítica. Com ele, se abre um novo questionamento, instaura-se o juízo crítico, uma vez que se inicia o processo de discussão da obra e não o de condução do observador à obra por meio do texto. Para Baudelaire, a melhor crítica era aquela capaz de agradar por sua dose de poesia, sem a preocupação fria e algébrica de querer dar explicações para tudo." (LUZ, 2006, p. 61)

${ }^{58}$ Em 1816, D. João VI criou a Escola Real das Ciências, Artes e Ofícios e, depois de sucessivos decretos que recriavam a instituição, em 1820, foi instituída a Real Academia de Desenho, Pintura, escultura e Arquitetura Civil. No entanto, seu funcionamento pleno só se concretizaria em 1826, já com o Brasil como país independente (LUZ, 2005).
} 
só absorvemos o gosto pelos salões como fizemos deles, mais que um "lugar", um espaço de sacralização de nossa arte, de confirmação de valores e de obrigatoriedade de comparecimento. (LUZ, 2005, p. 18)

Em 1845, foi instituído o Prêmio Viagem ao Exterior. Inspirado no Prêmio de Roma concedido pela Academia Francesa, seu objetivo era propiciar aos artistas recursos necessários para um aperfeiçoamento a ser realizado na Europa. As premiações outorgadas eram indicadas pela Congregação da Academia, que indicava a aquisição de obras para a Pinacoteca da Academia ${ }^{59}$. Havia também a premiação da medalha de ouro e prata, além da condecoração de diversas ordens e menções honrosas.

Depois da proclamação da República, a Academia Imperial "desapareceria enquanto nome, mas permaneceria viva em sua essência, renascendo [...] com o nome de Escola Nacional de Belas Artes" (LUZ, 2005, p. 84) e as exposições oficiais receberiam o nome de Salão Nacional de Belas-Artes. Os desafios colocados pela entrada da Arte Moderna no cenário nacional e, em 1940, causou a divisão do evento em duas seções: Belas-Artes e Moderna, até que em 1951, sob o impacto da I Bienal Internacional de Artes de São Paulo, surgiu o Salão Nacional de Arte Moderna. (LUZ, 2005)

O modelo estabelecido pelos salões nacionais se replicou por todo o país, sendo realizado seja sob a égide de governos estaduais e municipais seja por instituições privadas e associações. Como podemos observar, no estado de São Paulo, o Salão Paulista de Belas Artes foi criado em 1933, sob a gestão do interventor federal Armando Sales de Oliveira, seguindo os moldes da Escola Nacional de Belas-artes, a partir de 1951, coexistindo com o Salão Paulista de Arte Moderna.

Na região do $A B C$ não seria diferente: salões de Belas-Artes e Salões de Artes Plásticas foram realizados em Santo André ${ }^{60}$ e São Bernardo do Campo ${ }^{61}$

${ }^{59} \mathrm{O}$ acervo reunido a partir da Pinacoteca da Real Academia deu origem ao Museu Nacional de Belas-Artes, criado em 13 de janeiro de 1937.

60 O 1ํ Salão de Belas-Artes de Santo André foi organizado em 1947 pela Sociedade Amigos do Livro. No ano seguinte, após a realização da segunda edição desse salão, foi criada a Seção de Santo André da Associação Paulista de Belas-Artes. Em 1951, foi criada a Sociedade de Belas-Artes de Santo André (SBASA), que realizou seu primeiro salão em 1953. Em 1968, a Prefeitura Municipal de Santo André realizou o $1^{\circ}$ Salão de Arte Contemporânea como primeira atividade cultural realizada no novo Centro Cívico. As obras premiadas nesses salões passaram a compor o acervo municipal. No final da década de 1970, o Salão de Arte Contemporânea passou a denominar-se Salão Jovem de Arte Contemporânea. Os salões de Santo André são realizados até os dias atuais. (KLEEB, 2011)

${ }^{61}$ O Salão de Arte de São Bernardo do Campo começou a ser realizado em 1958 pela Associação Sambernardense de Belas-Artes (ASBA). Esses Salões possuíam premiações em dinheiro como 
Emerson Dionísio de Oliveira, em seu estudo sobre museus de arte localizados em centros regionais de cultura de fora do grande circuito das artes ${ }^{62}$, identificou a presença dos salões de arte na gênese desses museus. Discutiremos mais essa relação entre salões e museus no último capítulo. No entanto, esse estudo nos chamou atenção para um dos casos por ele analisados, o Museu de Arte Contemporânea de Campinas (MACC).

O MACC foi instituído pela Prefeitura Municipal em 1965, já tendo atrelado a si a criação do Salão de Arte Contemporânea de Campinas, que seria o provedor de acervo da instituição. Até onde conseguimos levar nossa pesquisa, este teria sido o primeiro salão a assumir a denominação "arte contemporânea". Além disso, a criação dessas duas instituições sofre a influência direta do Grupo Vanguarda (OLIVEIRA, 2010).

Como já dissemos no capítulo anterior, identificamos na raiz da criação dos salões de São Caetano do Sul influências desses acontecimentos, e, assim, decidimos aprofundar um pouco mais essa questão. Pensando no contexto socioeconômico e cultural da cidade de Campinas, podemos ver várias aproximações com São Caetano do Sul.

Começando pelo impacto causado pela instalação das estradas de ferro Paulista e Mogiana, entre 1872 e 1875, colocando a cidade numa posição de grande entreposto comercial no fornecimento de implementos agrícolas e máquinas de beneficiamento da produção cafeeira. Posteriormente, como porta de entrada do interior paulista, não perdeu sua hegemonia nem com a decadência do ramo cafeeiro. Nas décadas de 1950 e 1960, Campinas vivenciou um acelerado processo de industrialização, resultado dos mesmos planos desenvolvimentistas que impulsionaram a região do grande $A B C$, que a tornou um ponto de atração para correntes migratórias.

\footnotetext{
"Prêmio Prefeitura Municipal", Prêmio Câmara Municipal" e de algumas empresas apoiadoras, além de prêmios honoríficos. Mas somente a partir do $11^{\circ}$ Salão, de 1968, foi instituído o prêmio-aquisição e as obras premiadas passaram a compor o acervo da Prefeitura Municipal. Em 1977, os salões da ASBA passam a denominar-se Salões de Arte Contemporânea. O Prefeitura Municipal de São Bernardo retomará a realização de salões de arte em 1991.

62 Emerson Dionísio de Oliveira fez seu trabalho a partir de nove instituições localizadas em Campinas (Museu de Arte Contemporânea de Campinas), Olinda (Museu de Arte Contemporânea de Pernambuco), Curitiba (Museu de Arte Contemporânea do Paraná), Brasília (Museu de Arte de Brasília), Goiânia (Museu de Arte Contemporânea de Goiás), Campo Grande (Museu de Arte Contemporânea de Mato Grosso do Sul), Porto Alegre (Museu de Arte Contemporânea do Rio Grande do Sul), Ribeirão Preto (Museu de Arte de Ribeirão Preto) e Londrina (Museu de Arte de Londrina).
} 


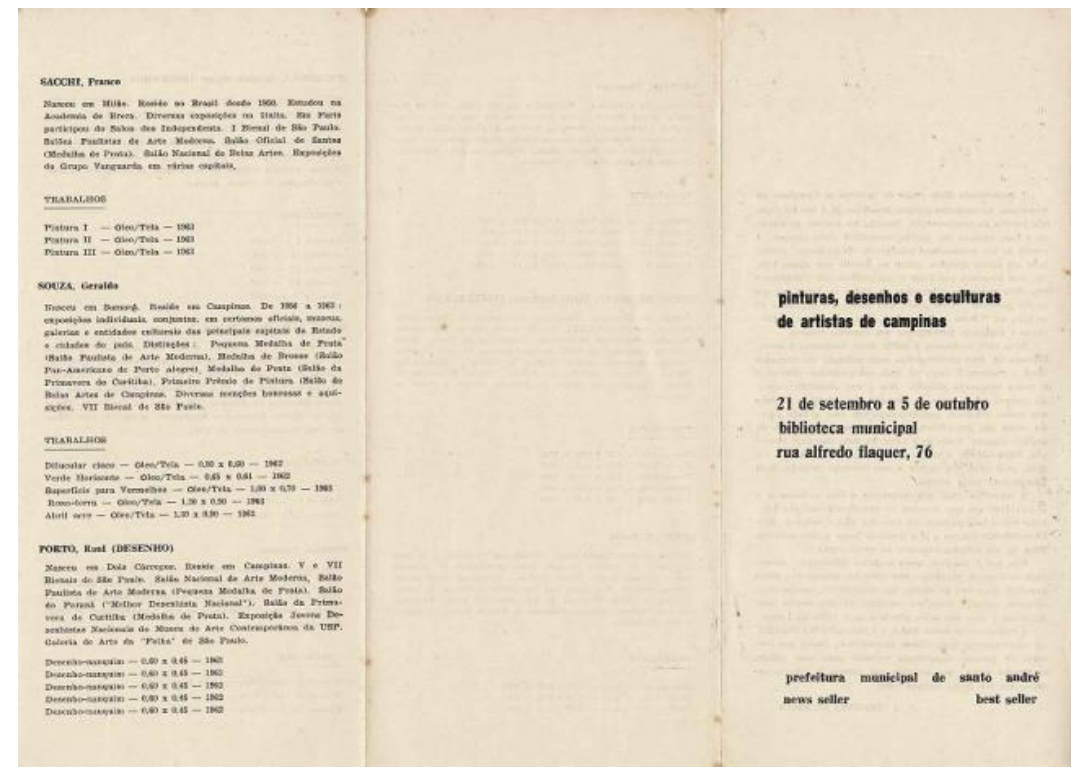

Figura 17 e 18 - Folder da exposição do Grupo Vanguarda em Santo André, 1963 Acervo Enock Sacramento
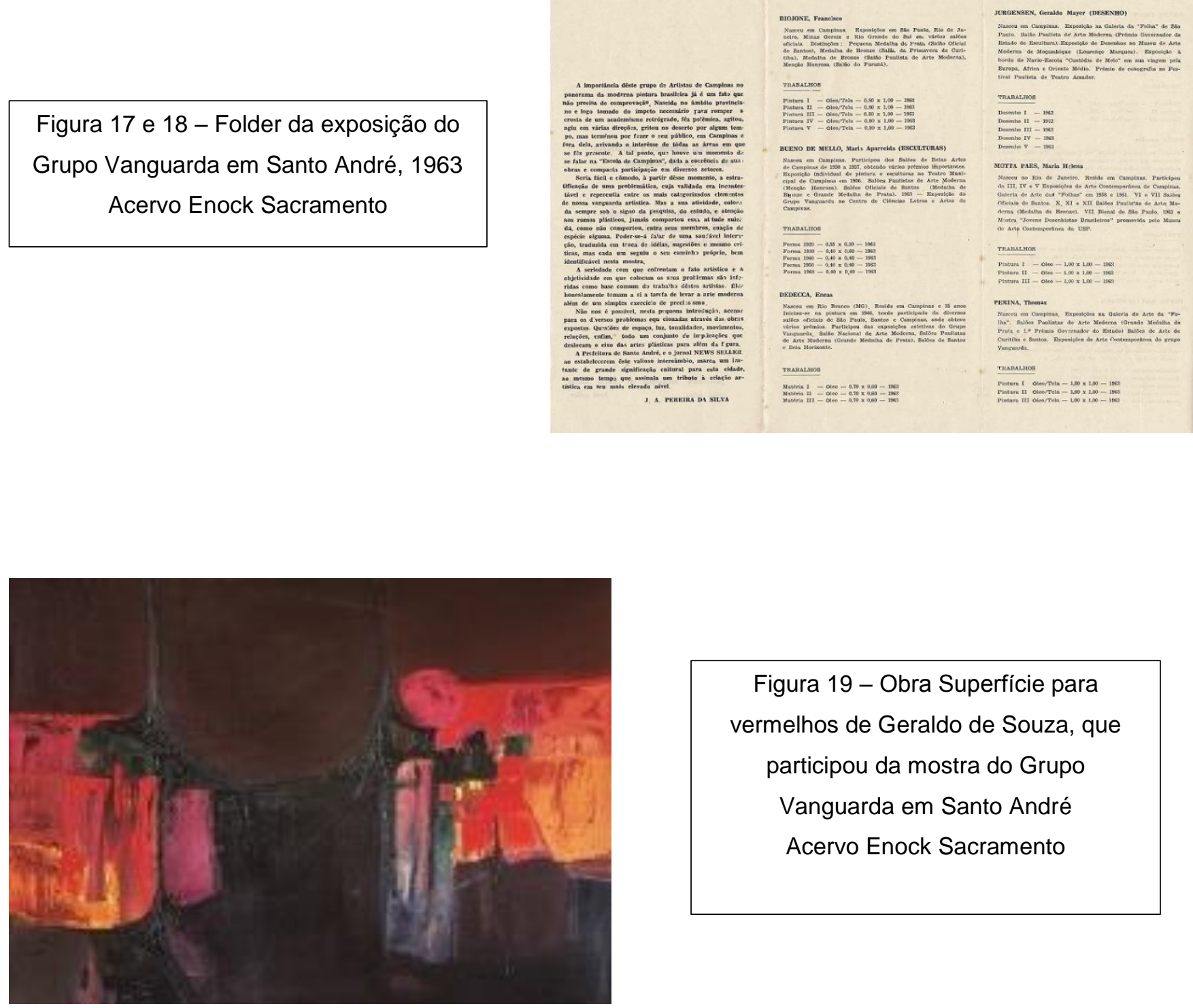

Figura 19 - Obra Superfície para vermelhos de Geraldo de Souza, que participou da mostra do Grupo Vanguarda em Santo André Acervo Enock Sacramento 
Assim, os equipamentos comunitários se redimensionam para atender à população que crescia e demandava melhores condições de vida. Projetos urbanísticos alargaram avenidas e criaram novos bairros. A vida cultural também recebeu incremento de novos espaços e novos grupos de artistas e promotores culturais, sendo um dos principais representantes desse movimento exatamente 0 Grupo Vanguarda (SILVA, 2000). Este era formado pelos artistas Thomaz Perina, Mário Bueno, Geraldo Jurgensen, Enéas Dedecca, Francisco Biojone, Franco Sacchi, Geraldo de Souza, Maria Helena Motta Paes e Raul Porto. Mais tarde, em 1964, novos membros integraram-se ao grupo: Bernardo Caro, Edoardo Belgrado, Geraldo Dècourt e Ermes de Bernardi.

Em 1957, Geraldo Jurgensen chegou do Rio de Janeiro, onde terminou o curso de Arquitetura, trazendo novas experiências de exposições de arte contemporânea. Uniu-se então aos artistas Thomaz Perina, Mário Bueno e Enéas Dedecca. O grupo decidiu organizar uma exposição juntamente com os alunos de Perina. Raul Porto compareceu com alguns desenhos e foram ainda convidados dois artistas italianos residentes em Campinas, Edoardo Belgrado e Franco Sacchi, além de outros nomes: Geraldo Décourt (de São Paulo), Ermes de Bernardi, Mário Carneiro (do Rio de Janeiro) e Lélio Coluccini. Esse episódio deu origem, em 04 de setembro de 1957, à I Exposição de Arte Contemporânea de Campinas, no saguão do Teatro Municipal. Assim, o espaço anteriormente reservado apenas para a arte tradicional começou a ceder lugar a uma arte menos usual.

A proposta "contemporânea" desejava conquistar um espaço importante em âmbito municipal, como já acontecera nos grandes centros do país. Os artistas ali reunidos tinham um desejo comum de romper com os parâmetros artísticos vigentes em Campinas.

Após a mostra, os artistas passaram a se reunir e iniciaram, então, a luta por um objetivo: criar a consciência da arte contemporânea na cidade de Campinas. Autodenominaram-se grupo Vanguarda e organizaram a II Exposição de Arte Contemporânea de Campinas, no andar térreo do Edifício Catedral. Com a participação do jornalista e poeta Alberto Amêndola Heinzl, redigem um manifesto contendo os objetivos, princípios e estratégias do grupo que foi publicado no Jornal do Centro de Ciências, Letras e Artes de Campinas, em junho de 1958. (ZAGO, 2007, pp. 6-8)

Essas ações chamaram a atenção de artistas do grupo concreto de São Paulo, como Waldemar Cordeiro, Décio Pignatari, Maurício Nogueira Lima e Hermelindo Fiaminghi, que passaram a apoiá-los articulando uma exposição na Galeria de Arte das Folhas de São Paulo ${ }^{63}$. Isso os coloca no cenário artístico paulistano fora das mostras oficiais (ZAGO, 2007).

${ }^{63}$ Sobre essa mostra, intitulada "Artistas de Campinas", o crítico José Geraldo Vieira destacou: "a surpresa não é a existência de artistas modernos em Campinas, mas a diversidade de sua arte: pintura, escultura e desenhos - e tudo comparável ao nível da mais recente arte europeia" (ZAGO, 2007, p. 11). 
É nesse contexto que, como vimos no capítulo anterior, o Grupo Vanguarda foi convidado por José Armando Pereira da Silva, em nome da Prefeitura Municipal de Santo André e do Jornal News Seller ${ }^{64}$, para realizar a mostra Pinturas, Desenhos e Esculturas de artistas de Campinas na Biblioteca Municipal de Santo André. Segundo relatos de José Armando e Enock Sacramento, essa exposição causou grande impacto no meio artístico da região ${ }^{65}$. Outra aproximação entre o caso campineiro e o nosso objeto de estudo foi assinalada no trabalho realizado por Renata Zago em sua dissertação de mestrado sobre os Salões de Arte de Campinas $^{66}$.

\begin{abstract}
O MAC-USP teve um papel relevante para a fundação de museus no interior do Estado. O museu ultrapassou as preocupações expositoras com uma diversidade de eventos culturais em sua programação. Para Campinas esse fato foi importante, principalmente devido a um programa de divulgação cultural em que o museu levava palestras, cursos e conferências a instituições em cidades do interior entre os anos 1964 e 67. Além disso, o MAC-USP organizou exposições temporárias e de obras do acervo em diversas cidades brasileiras que receberam a denominação de itinerantes ou circulares. Estas mostras tinham como objetivo compartilhar o patrimônio cultural, divulgar obras de artistas contemporâneos e tornar o acervo do museu conhecido. (ZAGO, 2007, p. 14)
\end{abstract}

Como vimos também no capítulo anterior, a presença do Museu de Arte Contemporânea da Universidade de São Paulo, através de seu diretor, Walter Zanini, foi um dos "introdutores" da arte contemporânea em São Caetano do Sul, influenciando diretamente os salões ali realizados.

Mas se muitos pontos aproximam os dois casos, um definitivamente os distancia: a ordem de criação das instituições. Em Campinas, a criação do MACC precedeu a criação do I Salão de Arte Contemporânea de Campinas, cujas obras premiadas estavam destinadas à formação do acervo do museu.

Assim, em setembro de 1965, a prefeitura municipal criou o Museu de Arte Contemporânea de Campinas José Pancetti (MACC) (...) Para sua constituição foram ouvidos diversos artistas da cidade, incluindo os acadêmicos. Ponderações dos artistas do Vanguarda foram decisivas quando Jacy Milani decidiu que seria criado um museu de arte contemporânea. Garantida sua implantação, tratou-se de realizar imediatamente a sua inauguração com o I Salão de Arte Contemporânea de Campinas. (ZAGO, 2007, p. 1)

${ }^{64} \mathrm{O}$ News Seller foi o primeiro jornal a dar cobertura a toda Região do $A B C$ e, a partir de maio de 1968, tornou-se o Diário do Grande ABC, maior jornal de circulação da região até os dias atuais.

${ }^{65}$ SILVA, José Armando Pereira da: depoimento [fev. 2019] Entrevista concedida à autora. São Paulo, 2019.

SACRAMENTO, Enock: depoimento [jul. 2020]. Entrevista concedida à autora. Santo André, 2020.

${ }^{66}$ Dissertação apresentada ao Instituto de Artes da Universidade Estadual de Campinas 
A estratégia adotada em São Caetano do Sul, de primeiro criar os salões que permitiriam a composição de um acervo de um futuro museu, acabou criando um hiato de 35 anos entre a promulgação da lei de criação dos salões até a inauguração da Pinacoteca Municipal. As consequências desse fato serão analisadas no próximo capítulo.

Conforme já foi citado no primeiro capítulo, o salão de arte contemporânea de São Caetano nasceu de uma solicitação assinada por Milton Andrade, Sinval Correia Soares, Arnaldo Ferrari, Jayme da Costa Patrão e Aluísio Domingo dos Santos. Nessa correspondência constavam também sugestões de criação do museu e de um acervo "através da aquisição de obras de arte, nacionais e estrangeiras, pelo Departamento de Educação e Cultura e através das comissões de seleção e premiação do salão em pauta" (PREFEITURA, 1966, p. 1), sobre o montante da verba necessária para realização do salão e incluía também um modelo de regulamento para o primeiro deles, que realmente foi a base usada pelos organizadores do evento. Duas ideias dessa proposta não foram acatadas. $\mathrm{Na}$ verdade, o título que consta nesse documento é Salão Estadual de Arte Plástica Contemporânea de São Caetano do Sul, mas a palavra Estadual está riscada.

Após essas considerações, abordaremos agora os resultados da análise dos Salões de Arte Contemporânea de São Caetano do Sul, matriz do acervo que é nosso objeto de estudo. Vale ressaltar que esta análise só foi possível porque conseguimos localizar os processos administrativos do Departamento de Cultura da Prefeitura Municipal da cidade, onde tivemos acesso a informações inéditas sobre todos os salões realizados.

Como o trabalho já citado de Renata Zago faz uma análise bastante aprofundada dos salões de Campinas, foi-nos possível continuar a traçar alguns pontos de tangência e de divergência entre os dois salões sem, no entanto, pretender fazer um estudo comparativo pormenorizado entre os dois casos.

Começaremos nosso exame pelos regulamentos dos salões, que estabelecem todas as regras de ordenação desses eventos, como estrutura, funcionamento e regras para participação dos artistas, sendo este o documento principal para esclarecer quaisquer dúvidas ou contestações. Esses regulamentos variaram ao longo dos anos a fim de atualizar os salões e torná-los mais atrativos. Trataremos dos seguintes aspectos dos regulamentos: Comissões Executivas, Comissões de Seleção e Premiação, o formato dos salões, as premiações, os 

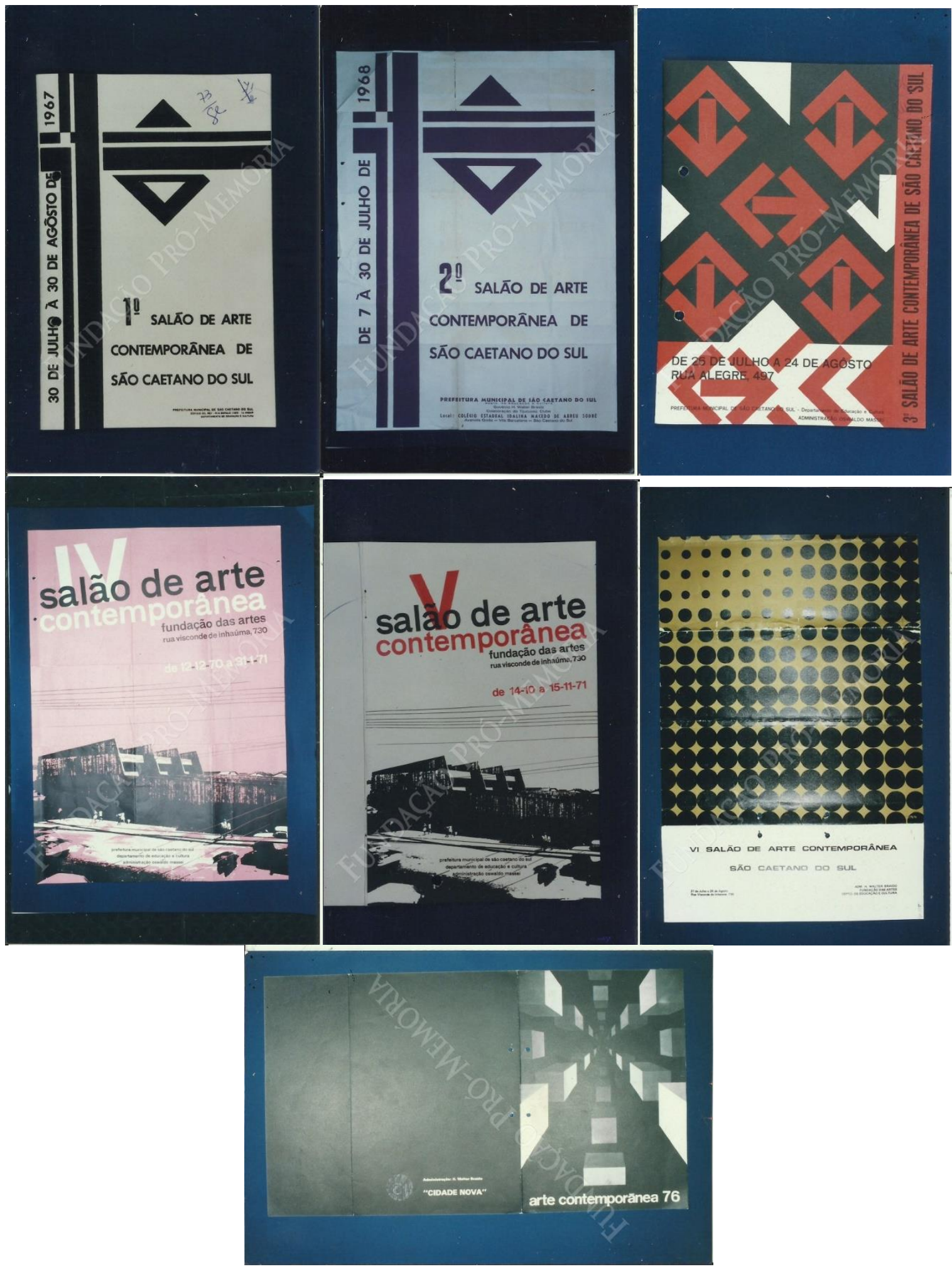

Figuras de 20 a 26 - Cartazes dos Salões de Arte Contemporânea Acervo Fundação Pró-Memória de São Caetano do Sul 
artistas e suas obras (participantes e premiados). ${ }^{67}$ Essa análise abrange dez edições realizadas. O IX Salão merecerá um tratamento à parte pelo modelo inovador adotado na sua realização.

\subsection{Comissões Executivas / Organizadoras}

Composta por cinco membros designados pelo Prefeito Municipal ${ }^{68}$, essas comissões tinham como incumbência a organização e promoção dos salões. Eram responsáveis também pela elaboração e cumprimento dos regulamentos de cada edição e a designação dos membros das Comissões de Seleção e Premiação (ad referendum do prefeito). Eram presididas pelo diretor do Departamento de Educação e Cultura da respectiva gestão. ${ }^{69}$

Ressaltamos a participação de Arnaldo Ferrari no I Salão, tanto na comissão executiva como na comissão de seleção e julgamento. Como um dos signatários da carta ao prefeito e artista consagrado que era, podemos inferir ter sido ele uma grande influência na configuração da estrutura do salão, pela sua grande experiência e vivência no meio artístico.

\subsection{Comissão de Seleção e Julgamento}

As comissões responsáveis pela organização e realização dos salões variaram a denominação ao longo dos anos. Nos primeiro salões, foram chamadas de Comissão de Seleção e Julgamento, a partir da terceira edição do evento, foram intituladas Comissão de Seleção e Premiação. Somente no IX Salão ela se denominou Comissão de Indicações.

Essas comissões tinham como atribuição zelar pelo "gabarito artístico" do salão, selecionando as obras que fariam parte dele, eliminando as demais previamente. Também deveriam opinar sobre a montagem dos trabalhos no ambiente onde o salão seria realizado. E por último, mas não menos importante, deveriam julgar os trabalhos conferindo-lhes prêmios, trabalhos estes que significavam a composição do acervo artístico da municipalidade.

\footnotetext{
${ }^{67}$ As Fichas Técnicas de todos os salões se encontram no ANEXO D.

${ }^{68}$ Com exceção do IX Salão, cuja Comissão Executiva teve três membros, e a do XI Salão, que teve oito membros.

${ }^{69}$ Com exceção do V Salão, que foi presidida pelo artista e empresário Alberto Aliberti.
} 
Essas comissões também eram compostas por cinco membros ${ }^{70}$,mas sua ordenação interna era variável. Nos dois primeiros salões, era mandatório que dois membros da comissão executiva fizessem parte dela. Diferentemente, em outros, foi estabelecido que alguns órgãos ${ }^{71}$ ligados ao cenário artístico enviassem representantes, podendo em algumas edições os artistas sugerir nomes para essa comissão, sendo convidados os que recebessem mais indicações. Essas regras para configuração das comissões de seleção e premiação variaram a cada edição, não estabelecendo um padrão. O que foi uma constante em todas as comissões foi a presença de nomes consagrados nacionalmente no campo das artes e com muita experiência na participação de júris em eventos semelhantes. Todas as comissões foram compostas majoritariamente por críticos de arte, artistas e intelectuais. Mário Schenberg, Arnaldo Ferrari, Hermelindo Fiaminghi, Ivo Zanini, José Geraldo Vieira, José Armando Pereira da Silva, Enock Fernandes Sacramento, Lisetta Levy, Alberto Aliberti e Sinval Correia Soares, foram os que participaram de mais edições dos salões ${ }^{72}$. Esses "jurados" das comissões participavam também de comissões semelhantes em bienais e salões por todo o País, inclusive nos Salões de Arte Contemporânea de Campinas. Isso demonstra a inserção dos salões de São Caetano em um contexto muito maior do que o circuito regional, fazendo parte também de um cenário nacional.

\subsection{Formato dos salões de São Caetano}

Os dois primeiros salões de São Caetano seguiriam o modelo tradicional dos salões de belas-artes, dividindo-se em quatro seções: pintura, escultura, arte gráfica e arte decorativa. Essa estrutura foi adotada também nos quatro primeiros salões de Campinas, apesar de ambos serem identificados como de arte contemporânea, um campo onde essa categorização não faz mais sentido.

Em São Caetano, cada artista poderia se inscrever com até três obras por seção. O que pudemos observar é que as seções não eram totalmente respeitadas

\footnotetext{
${ }^{70}$ Com duas exceções: o IX salão, que teve uma Comissão de Indicações com três membros, e o XI, cuja Comissão Julgadora teve três membros.

71 Foram convidadas as seguintes instituições: Associação Internacional de Artistas Plásticos (A.I.A.P.), Associação Brasileira de Críticos de Arte (ABCA), Associação Brasileira de Desenho Industrial (ABPI), Instituto dos Arquitetos do Brasil (IAB).

${ }^{72}$ Nas Fichas Técnicas dos Salões, que se encontram no Anexo D, é possível observar a composição de todas as Comissões e no Anexo E, encontra-se a lista dos participantes das Comissões de Seleção e Julgamento/Premiação.
} 


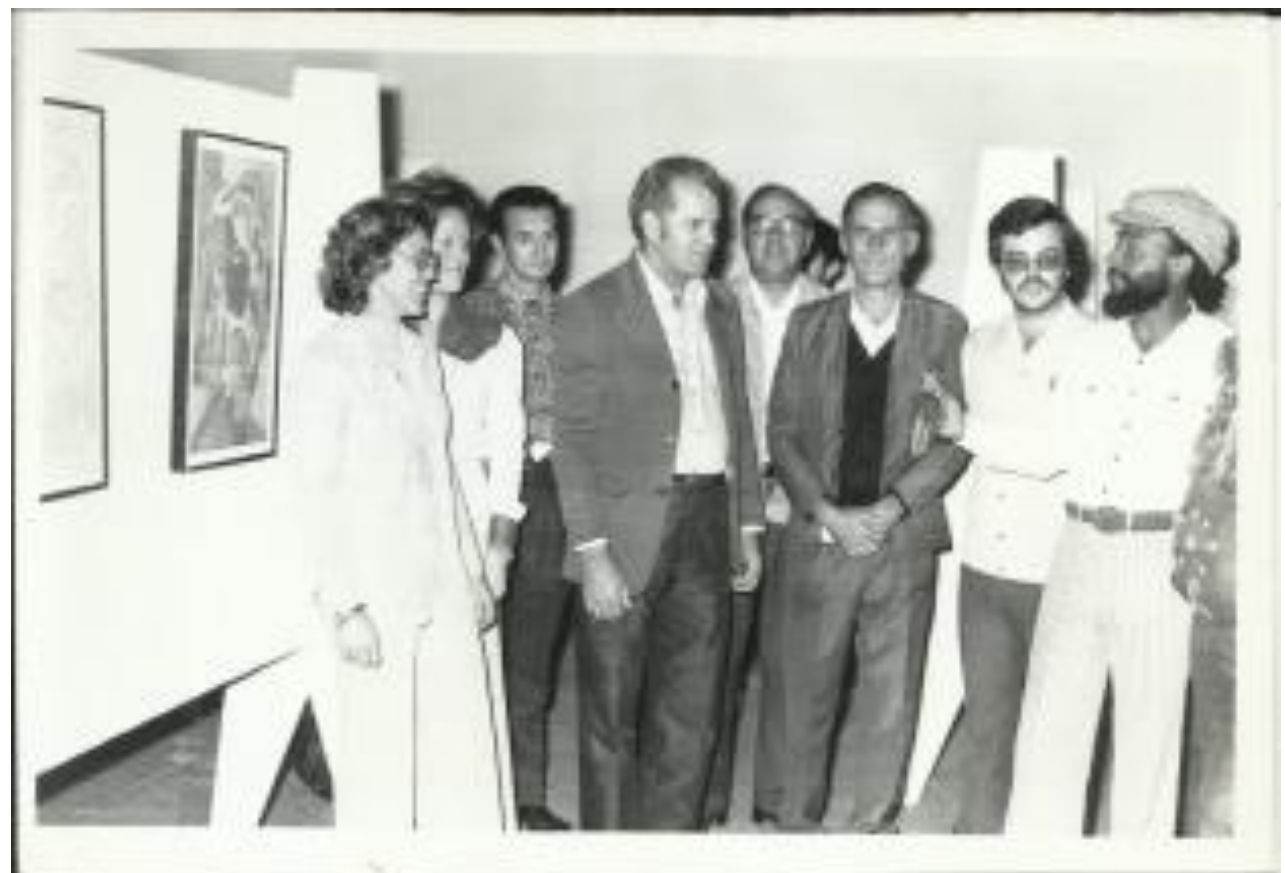

Figura 27 - Inauguração de um dos primeiro Salões de Arte Contemporânea. Em primeiro plano, os vereadores Sebastião Lauriano dos Santos e Fábio Ventura, o jornalista Humberto

Pastore e Aluísio Domingos dos Santos, final da década de 1960 Acervo Fundação Pró-Memória de São Caetano do Sul

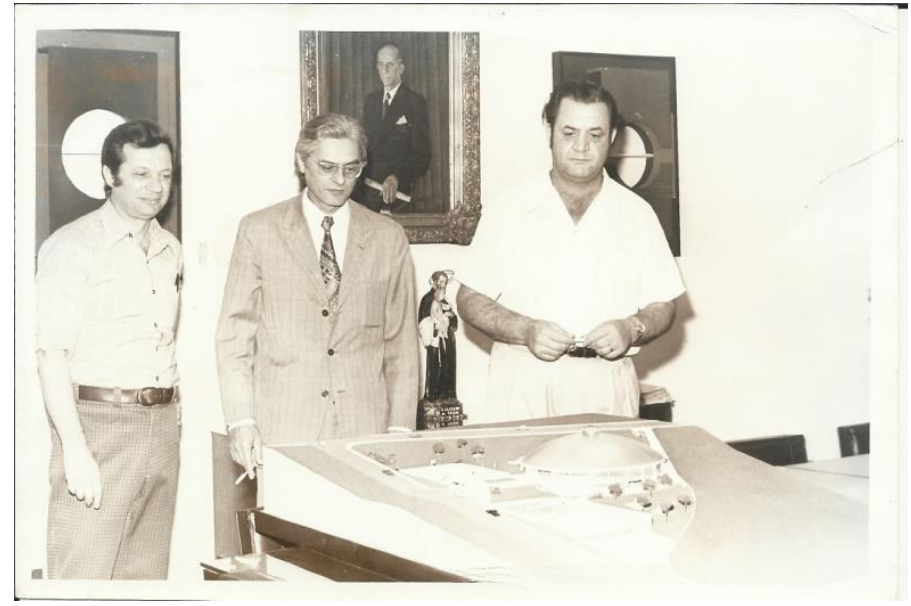

Figura 28 - Gabinete do Prefeito Hermógenes Walter Braido (terceiro da esquerda para a direita). O fundo, parte do tríptico Construção de Regis Machado da Silva, década de 1970.

Acervo Fundação Pró-Memória de São Caetano do Sul

Figura 29 - Gabinete do Prefeito Raimundo da Cunha Leite (primeiro da esquerda para a direita). O fundo, a obra Genesis de Bandarra, final da década de 1970. Acervo Fundação Pró-Memória de São Caetano do Sul

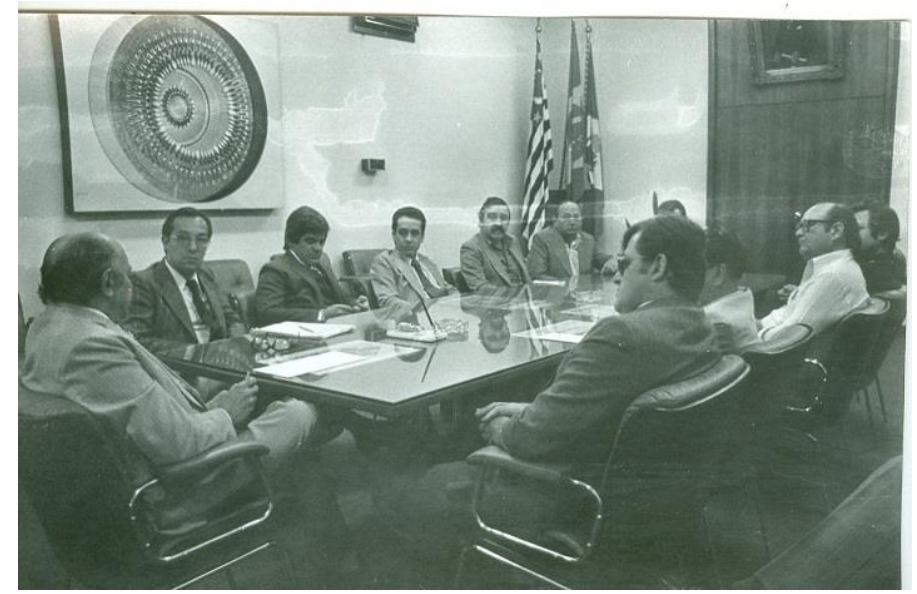


nem pelos artistas na inscrição das obras nem pela comissão julgadora, pois no I Salão, por exemplo, a artista que recebeu o primeiro prêmio na seção de Arte Gráfica foi Niobe Xandó, com a obra Quadro I, que hoje faz parte do acervo. Tal obra é uma pintura a óleo sobre tela. Esses dois salões também se aproximaram dos salões tradicionais na forma da premiação, mas isso será abordado mais adiante.

Esse formato mudou totalmente a partir do III Salão, realizado em 1969, o primeiro ano em que Enock Fernandes Sacramento fez parte da Comissão Executiva, criando um movimento que propiciou um ambiente favorável a mudanças $^{73}$. Segundo esse novo formato, os salões compreenderiam uma exposição de artes plásticas em suas diferentes modalidades: pintura, desenho, gravura, escultura, objeto, arquitetura e desenho industrial. Os artistas poderiam se inscrever apresentando três obras em qualquer uma dessas modalidades ou mesmo de outra manifestação artística, às quais o salão poderia promover, estimular e aprovar.

Coincidentemente, nesse mesmo ano, o V Salão de Campinas aboliu as categorias artísticas tradicionais, dando liberdade aos artistas para se inscreverem independente do suporte de suas obras.

Esse formato foi mantido até o VIII Salão, quando se inicia uma discussão sobre necessidade de atualização do modelo do evento.

Discutiu-se em seguida a conveniência de alterar regulamento do salão, no
sentido de atualizá-lo de acordo com novas correntes artísticas, uma vez
que o regulamento original conta já com 7 anos de existência. Levantou-se
a hipótese de restringir o salão a uma técnica, possivelmente a gravura,
convidando-se, isentos de seleção nomes representativos da gravura no
país, para participarem da mostra. A ideia foi aceita, enriquecida inclusive
com a proposição de que o VIII Salão pudesse abrigar uma exposição
didática de gravura e uma sala especial dedicada a um gravurista realmente
importante no cenário artístico. (PREFEITURA, 1975, p. 10)

E assim foi feito, o VIII Salão foi dedicado à gravura e teve uma sala especial com obras de Oswaldo Goeldi, com texto de Enock Sacramento. ${ }^{74}$ Com apenas uma diferença: a edição não foi realizada com artistas convidados, mas sim através da abertura de inscrições.

\footnotetext{
${ }^{73}$ SACRAMENTO, Enock: depoimento [jul. 2020]. Entrevista concedida a autora. Santo André, 2020.

${ }^{74}$ Oswaldo Goeldi, Mestre da Xilogravura, publicado na edição n ${ }^{\circ} 3$ da Revista Artis da Fundação das Artes de São Caetano do Sul.
} 
O IX Salão levou experimentação de novos formatos a um novo patamar, o que fez com que ele se diferenciasse de tal forma dos demais que optamos por tratá-lo individualmente, ao final desta análise global dos salões.

Depois da inovação, não temos muitas informação sobre a continuidade da experiência, pois do X Salão, realizado em 1979, não há muita documentação. No processo administrativo do evento, não consta uma cópia do regulamento da edição em questão e nenhum outro documento indicando de que forma se deu participação dos artistas (inscrição, convite ou indicação).

$\mathrm{Na}$ verdade, este foi o último salão organizado dentro do "projeto" que havia dado origem ao evento onze anos antes. Em 1983, Milton Andrade deixaria a direção da Fundação das Artes, Oscar Garbelotto também já não fazia mais parte da Prefeitura Municipal de São Caetano. Sem a presença de Andrade, a Fundação das Artes mudaria seu perfil de articulador cultural da cidade para assumir o papel de escola de artes. Sem esses articuladores, os salões caíram no esquecimento, apesar de sua Lei de Criação, que estabelecia a sua realização anual ainda estar em vigor. ${ }^{75}$

O XI Salão foi uma edição extemporânea, ocorrida em 1988, durante a terceira gestão do Prefeito Hermógenes Walter Braido, numa tentativa de resgate do projeto original. $\mathrm{O}$ formato adotado foi semelhante ao que havia se estabelecido a partir do III Salão, mas sem conseguir atrair um número expressivo de artistas como as edições anteriores.

\subsection{Premiações}

Como citamos anteriormente, os dois primeiros salões seguiram um modelo tradicional também nas premiações. O Prêmio Prefeitura Municipal de São Caetano do Sul, de caráter aquisitivo, era estabelecido de acordo com as seções, sendo que as categorias consideradas "mais nobres" (pintura e escultura) tinham valores maiores. No I Salão foram concedidos também prêmios honoríficos para cada seção - medalhas de ouro, prata e bronze e menções honrosas.

Os valores dos prêmios do I Salão eram de NCr\$600,00 para primeiro prêmio e $\mathrm{NCr} \$ 400,00$ para o segundo prêmio das seções de pintura e escultura e

\footnotetext{
${ }^{75}$ Apesar dessa determinação em Lei, os salões não se realizarão sequencialmente, havendo hiatos entre eles.
} 
NCr\$ 400,00 para o primeiro prêmio e NCr\$200,00 para o segundo prêmio das seções de arte gráfica e arte decorativa.

No II Salão, os valores de premiação foram aumentados e equiparados para as quatro seções, sendo o primeiro prêmio de $\mathrm{NCr} \$ 1.000,00$ e o segundo de NCr\$ 500,00 . Foi instituído também o prêmio "Prefeito Hermógenes Walter Braido" de caráter aquisitivo no valor de NCr\$2.000,00 para o melhor trabalho do salão. A partir dessa edição foram abolidas as premiações de medalhas, permanecendo como premiação honorífica as menções honrosas.

A partir do III Salão, as formas de premiação mudaram totalmente: passaram a ser atribuídos aos melhores trabalhos (com exceção dos projetos, maquetes ou protótipos relativos à arquitetura e desenho industrial) prêmios de caráter aquisitivo num valor não superior a um montante pré-estabelecido, no caso do III Salão, NCr\$ $12.000,00$. Os artistas receberiam o valor que haviam declarado em suas obras no momento da inscrição, desde que não excedesse um valor pré-determinado, no caso NCr\$3.000,00. Os projetos, maquetes ou protótipos relativos à arquitetura e desenho industrial, por não serem passíveis de aquisição, poderiam receber prêmio de participação com um valor fixo (NCr\$ 500,00). Nesse salão houve ainda o prêmio-aquisição Chocolates Pan, cujo valor não conseguimos apurar.

No IV Salão, a única mudança foi o nome do prêmio destinado à melhor obra do certame, que passou a ser prêmio "Prefeito Oswaldo Samuel Massei", devido à mudança na gestão municipal. No VI Salão, o valor da premiação em caráter aquisitivo foi reajustado, passando a ser $\mathrm{Cr} \$ 15.000,00$, e prêmio-participação passou a ser Cr\$1.000,00. Já não havia mais o prêmio para a melhor obra do salão. No VII Salão, o valor da premiação em caráter aquisitivo salta para Cr $\$ 20.000,00$, permanecendo o prêmio-participação no mesmo valor.

Já no VIII Salão, não há mais o prêmio de participação e o valor para o prêmio-aquisição passa a ser Cr\$25.000,00. O IX Salão manteve o mesmo padrão para premiação, destinando uma verba de $\operatorname{Cr} \$ 35.000,00$ para aquisição dos trabalhos expostos. Para o X Salão, não sabemos, como já foi dito, quais as regras estabelecidas no regimento, mas foi pago aos artistas um valor de $\operatorname{Cr} \$ 70.200,00$. E no derradeiro, XI Salão, foi fixado um prêmio aquisitivo no valor de Cz\$350.000,00.

A premiação é um fator relevante a ser levado em conta na análise dos salões de arte uma vez que, segundo Aracy Amaral, “(...) a participação desses artistas não se deve apenas à relevância do evento, mas ao fato de que em 
inúmeras edições foram oferecidos prêmios em dinheiro aos primeiros colocados. Isso era uma prática frequente de instituições, o que fazia com que esses artistas enviassem seus trabalhos a Salões no Brasil inteiro" (apud ZAGO, 2007, p. 18).

\subsection{Os Artistas}

Sobre os artistas que participaram dos salões de São Caetano, não realizamos uma análise da representatividade dos mesmos do ponto de vista da história da arte, e nem nos debruçamos sobre suas biografias. Direcionamos nossas análises para os aspectos quantitativos de participação e da abrangência com relação à origem dos participantes, a fim de avaliar o alcance dos salões de São Caetano (no nível regional, estadual e nacional).

Quanto ao aspecto qualitativo, pudemos assinalar a presença tanto artistas consagrados como Lothar Charoux, que participou das quatro primeiras edições, tendo recebido prêmio aquisição no III Salão com a obra Vibração, e Menção Especial de Mérito no IV Salão, como de jovens artistas que estavam iniciando suas carreiras no mundo das artes.

É interessante ressaltar que podemos encontrar esses mesmos nomes na relação de participantes de vários outros salões contemporâneos aos de São Caetano, como os salões de Campinas e de Santo André. Podemos citar alguns desses nomes: Antônio Henrique Amaral, Humberto Espíndola, Claudio Tozzi, Vera Ilce, Aldir Mendes de Souza, Alice Brill, Vania Pereira, Niobe Xandó, Rubens Gerchman, Ubirajara Ribeiro, Evandro Carlos Jardim e Antônio Carlos Rodrigues $(\text { Tuneu })^{76}$. Podemos observar que as obras desses artistas se espalharam por muitos museus regionais por conta desses salões. Muitos deles alcançaram grande destaque no cenário artístico nacional. Assinalamos também a participação de alguns desses artistas, como Claudio Tozzi, Rubens Gerchman e João Suzuki em várias edições dos programas de exposições "Jovem Arte Contemporânea”, "Jovem Desenho" e "Jovens Gravuras", organizadas por Walter Zanini no Museu de Arte Contemporânea da Universidade de São Paulo, realizadas nas décadas de 1960 e 1970. 77

\footnotetext{
${ }^{76}$ A relação dos artistas participantes de todos os salões se encontra no ANEXO F.

77 "Os objetivos das exposições para jovens do Museu de Arte Contemporânea da Universidade de São Paulo são diversos daqueles do salon tradicional. Este visa ao recenseamento de extratos mais definidos e à sua consagração. Com limite de idade em torno dos 35 anos, as mostras destinadas às
} 
Vale aqui analisar a inserção dos artistas da região do ABC. Notamos uma participação bastante tímida daqueles que tinham uma carreira artística estabelecida. Aluísio Domingos dos Santos participou dos três primeiros salões, recebendo prêmio aquisição no III deles; Sinval Correia Soares participou do IV, VI e VII Salões e foi premiado nas duas primeiras ocasiões, sendo ambos os artistas de São Caetano do Sul. Já os artistas de Santo André Paulo Chaves e João Suzuki participaram de duas edições cada um: o primeiro participou do I e do IV Salões, sendo premiado neste último. Suzuki participou dos I e do VII Salões, sendo premiado nos dois. Representando a cidade de Mauá, Hans Suliman Grudzinski participou também da primeira, da quinta e da oitava edição, sendo premiado nas duas últimas. ${ }^{78}$

A tabela a seguir, apresenta o número de artistas participantes em cada edição dos salões e seus locais de origem, permitindo uma análise sobre a abrangência dos Salões de São Caetano do Sul.

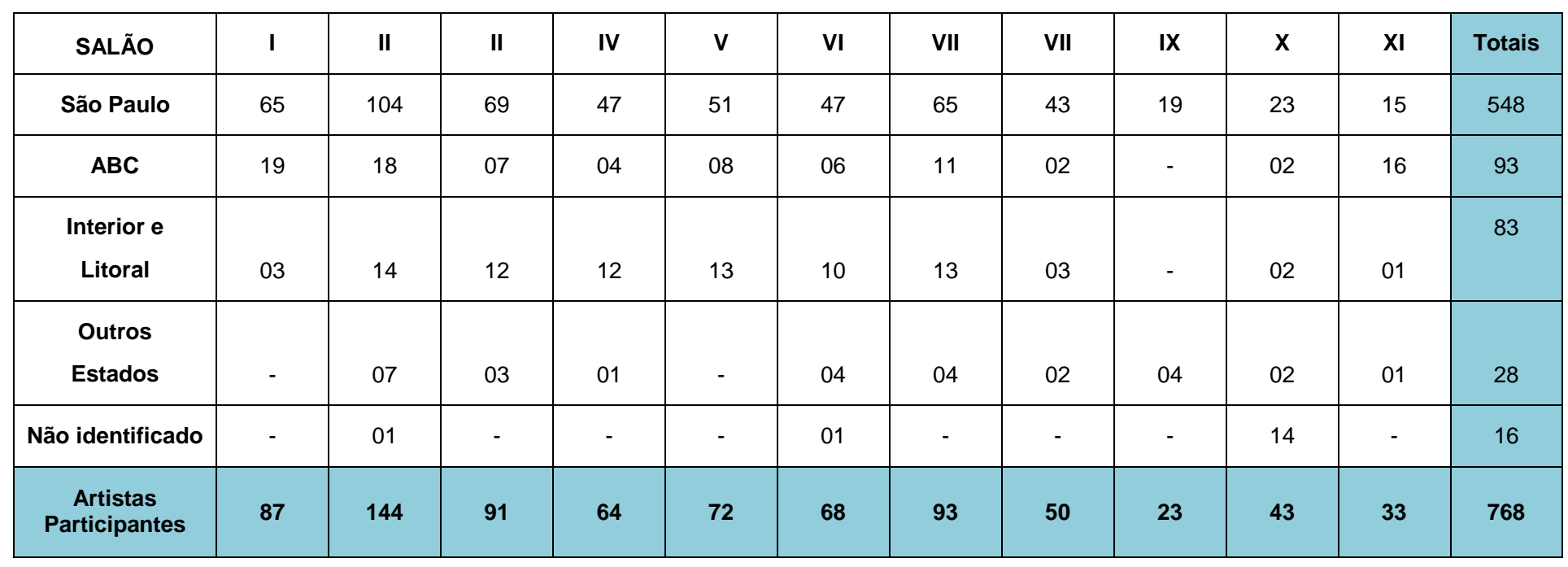

Tabela 1 - Artistas participantes dos Salões de Arte Contemporânea de São Caetano do Sul de acordo com região de origem elaborada pela autora dessa dissertação.

A partir dos números apresentados, podemos concluir que a maioria dos participantes era composta por artistas da cidade de São Paulo. Observa-se uma

gerações ascendentes voltam-se aos estreantes já com base mínima de valor criativo e para os que se encontram em evidente processo de afirmação." (FREIRE, 2013, p. 225)

${ }^{78} \mathrm{Um}$ dos mais expressivos artistas nacionais, Luiz Sacilotto, natural de Santo André, não participou de nenhum dos Salões de São Caetano. Muito embora Enock Sacramento tenha narrado a sua presença em uma das reuniões da Comissão de Seleção e Premiação do III Salão, quando todos pararam os trabalhos para assistir a chegada do Homem à Lua. (SACRAMENTO, Enock: depoimento [jul. 2020]. Entrevista concedida a autora. Santo André, 2020). 
única exceção a isso no XI Salão, que como dissemos foi uma edição extemporânea.

Já a presença de artistas da Região do $A B C$ foi mais significativa nas duas primeiras edições, passando a ser superada pela participação das cidades do interior e litoral do estado nas demais edições. Mais uma vez a exceção foi o XI Salão, onde a presença dos artistas do $A B C$ foi a mais expressiva. Da mesma forma, ressaltamos a participação de artistas de São Caetano do Sul, que se destacaram nas duas primeiras edições, decaindo fortemente nas demais.

No âmbito estadual, foi registrada a participação de artistas de dezessete cidades de todas as regiões do Estado de São Paulo, o que nos permite considerar que os salões de São Caetano alcançaram uma abrangência ampla. ${ }^{79}$

Já com relação à participação de artistas dos outros estados, estas foram minoria nas nove edições em que ocorreram os salões, o que, a nosso ver, não autoriza a identificação desses salões como de abrangência "nacional". ${ }^{80}$

\subsection{As obras de arte}

Não fez parte do escopo deste estudo realizar uma análise detalhada das obras de arte, participantes e premiadas, nos salões, da perspectiva da história da arte, muito menos houve a pretensão de verificar se as mesmas se enquadram na "categoria" da arte contemporânea. Nosso objetivo foi registrar quais informações poderíamos acrescentar às obras remanescentes desses eventos.

Observamos que, das diversas categorias artísticas das obras que foram contempladas com aquisição nos salões de São Caetano, permaneceram na coleção fundadora da Pinacoteca Municipal somente as pinturas, as gravuras e duas obras que podemos classificar como assemblages. ${ }^{81} \mathrm{Na}$ documentação preservada nos Processos Administrativos não há registros sistemáticos sobre as técnicas das obras, embora essas informações fossem solicitadas nas fichas de inscrição. Das

${ }^{79}$ Os salões de São Caetano contaram com a participação de artistas das cidades de Atibaia, Campinas, Campos do Jordão. Capivari, Franco da Rocha, Guarulhos, Jaboticabal, Jundiaí, Piracicaba, Presidente Prudente, Ribeirão Preto, Santos, São José dos Campos, São Vicente, Sorocaba, Taubaté, Votuporanga.

${ }^{80}$ Participaram artistas de Belo Horizonte, Campo Grande, Curitiba, Olinda, Porto Alegre, Recife, Rio de Janeiro, Salvador e Santa Maria.

${ }^{81}$ Termo francês criado em 1953 por Jean Dubuffet para descrever obras de arte feitas de fragmentos de materiais, naturais ou não. Alguns críticos defendem que o termo só deve ser aplicado a peças tridimensionais e não a colagens, mas não é usado com precisão e já foi aplicado a ambientes ou fotomontagens. Ganhou importância com a exposição que teve lugar em Nova lorque, no MoMA, em 1961, intitulada The Art of Assemblage. 
poucas informações que conseguimos obter sobre o assunto, identificamos a premiação de esculturas, objetos e tapeçarias.

Por outro lado, conseguimos recompor toda a relação de obras contempladas com os prêmios-aquisição, e assim temos agora a identificação do acervo "ausente". Das cento e sessenta obras adquiridas nas premiações das onze edições dos salões, apenas cento e seis fazem parte da coleção fundadora da Pinacoteca. Há ainda vinte e nove obras que constam dessa coleção, sendo que vinte delas não foram premiadas, e nove obras sequer foram aceitas, mas nunca foram retiradas pelos artistas. ${ }^{82}$

Não sabemos qual foi o destino de cinquenta e três trabalhos que deveriam fazer parte dessa coleção. Isso significa que 33\% daquele que seria o "acervo municipal" se perderam. Foram obras dos artistas Heinz Kuhn, Ubirajara Ribeiro, Leila Porto, Armando Sendim, Lothar Charoux, Antônio Lizárraga, Gerty Saruê, Evandro Carlos Jardim e muitos outros das quais nos restou somente o título. ${ }^{83}$

\subsection{O IX Salão}

Como havíamos dito anteriormente, a partir do VIII Salão, iniciaram-se entre os organizadores proposições a respeito da atualização do modelo dos salões de arte. Inspirados pela mostra Arte Agora I/Brasil $70-75,{ }^{84}$ promovida conjuntamente pelo Jornal do Brasil, a Light e o Museu de Arte Moderna do Rio de Janeiro, cujo objetivo era realizar um levantamento, em nível nacional, de artistas que surgiram e/ou se afirmaram no período de 1970 a 1975 nas diversas modalidades da criação visual no Brasil, foi decidida a adoção de um novo modelo para a nona edição dos salões. Baseado nos regulamentos dessa mostra, o salão de arte de 1976 foi realizado num formato de uma exposição de arte contemporânea, com o objetivo de reunir e premiar trabalhos representativos de artes visuais, em suas diferentes modalidades.

\footnotetext{
${ }^{82}$ A relação das obras não premiadas e/ou não aceitas que permaneceram no acervo se encontra no ANEXO $\mathrm{H}$.

${ }^{83}$ A relação das obras premiadas que se perderam se encontra no ANEXO G.

${ }^{84}$ Nas primeiras páginas do Processo Administrativo oㅡ 2781/76, que diz respeito à realização do Salão de Arte Contemporânea do mesmo ano, encontra-se o regulamento da mostra ARTE AGORA I/BRASIL 70-75 (pág. 4) e uma cópia da carta-convite destinada à Luís Gregório Correa, convidandoo para participar da mostra ARTE AGORA I, enviada pelo gerente de relações públicas do Jornal do Brasil, com detalhes de funcionamento da mesma. Na sequencia do Processo, encontramos o texto e uma nova lei alterando o formato e o regulamento dos Salões de Arte Contemporânea de São Caetano do Sul.
} 


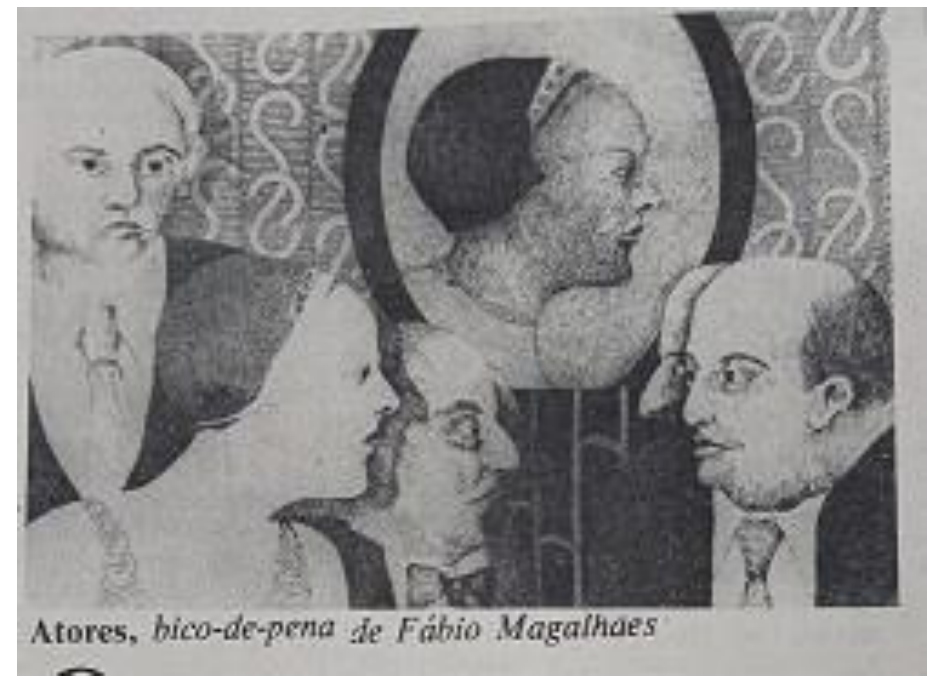

Figura 30 - Obra de Fábio

Magalhães, participante do IX Salão de Arte Contemporânea. Diário do Grande ABC, 18 jun. 1976

Figura 31 - Happening de Ivald Granato na abertura do IX Salão de Arte Contemporânea. Diário do Grande ABC, 01 ago. 1976

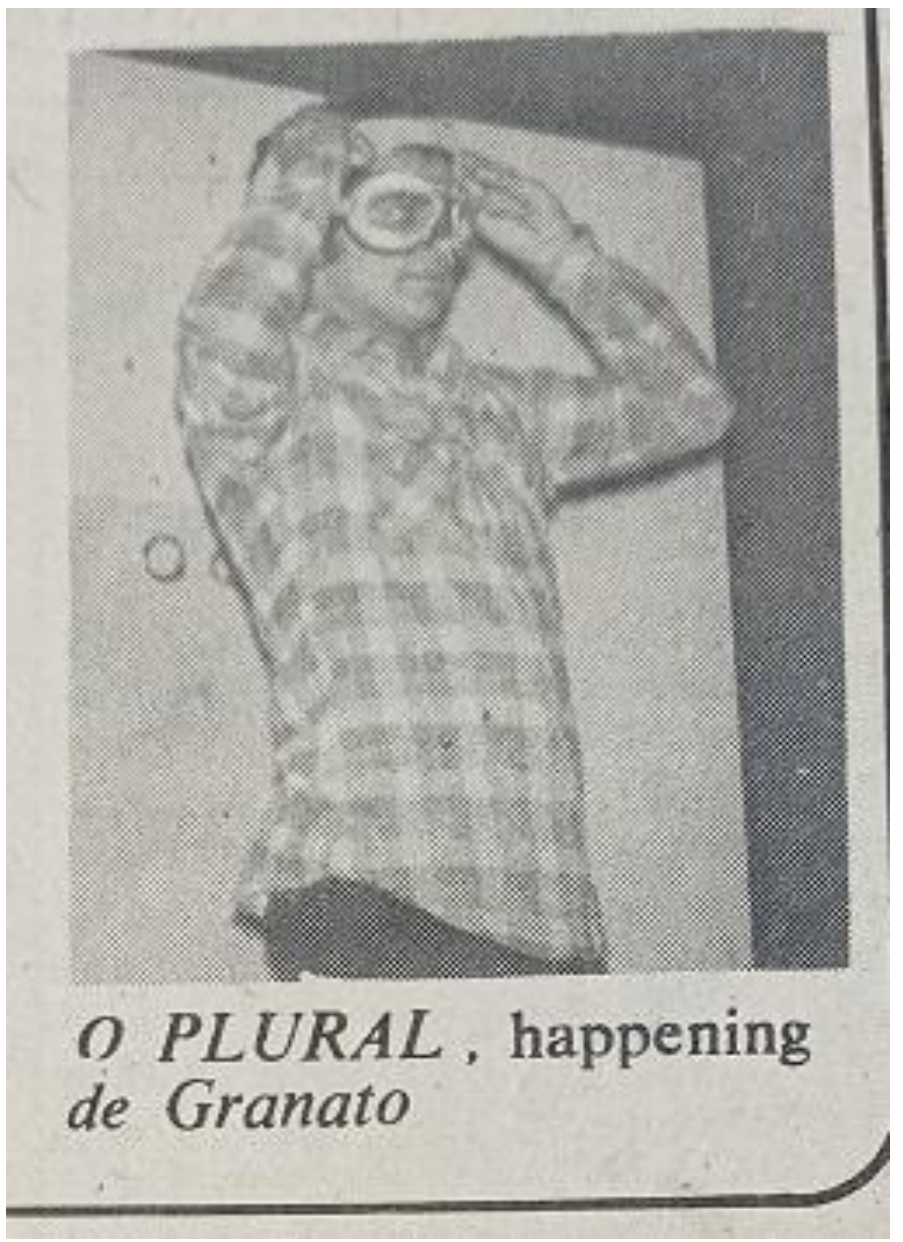


Sob a denominação Arte Contemporânea/76 a mostra mudou a maneira de participação dos artistas. Ao invés de se abrirem inscrições, a Comissão Organizadora convidou artistas expositores a partir da indicação de especialistas da área. Foram chamados os seguintes profissionais para a indicação dos artistas:

- Prof. ${ }^{\text {a }}$ Aracy Abreu Amaral - Diretora Técnica da Pinacoteca do Estado de São Paulo;

- Maria Eugênia Franco - Diretora do Departamento de Documentação e Informação Artística da Prefeitura Municipal de São Paulo;

- Dr. Carlos Von Schmidt - Diretor do Museu de Arte Brasileira da Fundação Armando Álvares Penteado;

- Olívio Tavares de Araújo - Crítico de Artes Plásticas da Revista "Veja";

- Paulo Mendes de Almeida - Presidente da Comissão de Arte do Museu de Arte de São Paulo;

- Pietro Maria Bardi - Diretor do Museu de Arte de São Paulo (hoje Assis Chateaubriand);

- Prof. Walter Zanini - Diretor do Museu de Arte Contemporânea da Universidade de São Paulo.

Paulo Mendes de Almeida e Walter Zanini não enviaram indicações. Os demais arrolaram em suas listas nomes de artistas já conhecidos e ou que já começavam a ter alguma visibilidade em suas carreiras. Alguns nomes também constavam em mais de uma lista de indicados. Uma vez convidados, os artistas poderiam apresentar até quatro obras. Os trabalhos enviados deveriam fornecer uma dimensão de contemporaneidade e deveriam, se possível, serem inéditos.

No regulamento da mostra também havia uma verba destinada à aquisição de obras, embora não deixasse claro a quem caberia a escolha das mesmas. $\mathrm{Na}$ documentação consultada também não havia nenhuma referência a tal atribuição. que podemos supor é que a Comissão Executiva deva ter assumido essa incumbência.

Esse novo formato causou grande repercussão na imprensa. Sob o título “Novos não entram no salão de São Caetano", o jornal O Estado de São Paulo trouxe as seguintes críticas ao novo modelo.

Este ano há uma inovação no Salão de Arte de São Caetano que será inaugurado no dia 30 de julho: artistas novos, ainda desconhecidos, estão proibidos de participar. Isto porque os organizadores da promoção, patrocinada pela Fundação das Artes de São Caetano do Sul, concluíram que a forma tradicional dos salões perdeu sua validade cultural. Em vez dos novos, foram convidados quase 50 nomes já consagrados, por indicação de críticos e diretores de organismos culturais de São Paulo. 
Milton Andrade, diretor da Fundação e um dos idealizadores do salão, atribui o fracasso da maioria das exposições à falta de critério na seleção dos artistas. "Criamos novos regulamentos", disse, para evitar que artistas já conhecidos e consagrados misturem-se com os novos, à procura de caminho. Isso, porém, não quer dizer que os novos não terão oportunidade. Pretendemos criar outro salão no fim do ano com um tipo de premiação que não seja a aquisição de obras, somente para os novos. Teremos assim, anualmente, um salão em julho e outro em dezembro".

Embora o regulamento previsse a participação de 50 artistas, isso não vai ser possível, pois alguns apareceram em mais de uma lista. Além disso, algumas das pessoas convidadas para indicar artistas, citaram nove nomes em vez de dez. Cada um dos expositores poderá participar com quatro obras. A comissão organizadora destinará verba de 35 mil cruzeiros para a aquisição de trabalhos expostos no salão de Arte Contemporânea. (SUCURSAL do ABC, 1976, p. 9)

Já o jornal regional Diário do Grande $A B C$, acolheu o novo modelo com evidente entusiasmo:

O Departamento de Educação e Cultura de São Caetano do Sul acaba de firmar as bases para o Salão de Arte Contemporânea do município, que este ano não terá este título mas apenas o de Arte Contemporânea 76, e objetivará apresentar obras de 50 artistas contemporâneos das artes visuais no Brasil. No ano passado, o salão anual de São Caetano já demonstrava uma tendência para a tão necessária remodelação dos já defasados salões de arte, momento em que realizou uma didática e dinâmica mostra especialmente destinada aos artistas atuantes na área da gravura. O passo deste ano, no entanto, é muito mais arrojado e merece desde já a total difusão para que venha a ser uma mostra amplamente visitada, não apenas pelo público da região, pois, sem dúvida, o nível a que se propõe a iniciativa deverá despertar a atenção dos cultuadores da arte em todo território brasileiro.

Totalmente novo em sua estrutura, com regulamento reformulado, Arte Contemporânea 76 paira como uma consciência nova no panorama das artes visuais brasileiras. Todos sabem da falta de eficácia dos salões que se acomodam aos esquemas tradicionais, já totalmente desgastados, sem interesse para as pessoas que apreciam arte e nada didáticos para os que necessitam entendê-la.

Tratando-se de uma iniciativa original e merecedora do amis amplo apoio, reproduzimos aqui na integra o novo e benvindo regulamento. (ARTES Plásticas, 1976)

É digna de nota a participação do artista Ivald Granato, com o happening $O$ Plural, que foi apresentado no evento de abertura da mostra. Paulo Klein, crítico de arte do Diário do Grande ABC, em seu artigo "Aberta ao público com a não-arte de Granato", traz uma minuciosa descrição do happening e uma fala do então Diretor de Educação e Cultura, João José Dario, responsável pela organização do evento, que achamos interessante destacar, pela postura "vanguardista" deste gestor municipal: 
O prof. João José Dario, em seguida à apresentação, dizia: "Quem pode dizer se não será esta forma de manifestação que transmitirá de fato a arte no futuro? Acredito que nossa iniciativa, de abrir esta mostra para nomes significativos da arte atual, só vai acrescentar caminhos à atividade artística local. Precisamos ter conhecimento de causa para criticarmos. Repleta de plasticidade e colorido, ou trágica e agressiva, a arte, essa é a grande verdade, é um bálsamo para o homem contemporâneo. Frente ao ridículo, talvez o homem analise com mais objetividade seu papel na sociedade em que vive". (KLEIN, 1976).

O que podemos supor a respeito dessa experiência é que ela não deve ter sido bem-sucedida, uma vez que o X Salão retomou o modelo anterior, e o salão destinado aos novos artistas, citados nos artigos, nunca foi realizado. Dos cinquenta artistas convidados para a mostra Arte Contemporânea/76, somente vinte e três participaram dela, apresentando oitenta e quatro obras. Destas, treze foram adquiridas com os prêmios-aquisição ${ }^{85}$.

\subsection{Estratégias de Comunicação}

Um ponto importante a se destacar na organização dos salões de São Caetano do Sul foi o cuidado com a sua divulgação. Em várias edições há a designação de um responsável pelas relações públicas. Percebemos que, ao longo do tempo, deve ter sido composto um grande mailing em relação ao evento e, em cada edição, podemos observar na documentação o envio de correspondência convidando artistas de todo o País para se inscreverem nos salões. Outra prática adotada era a realização de almoços com especialistas, críticos de arte e a imprensa para divulgação dos lançamentos de uma nova edição do evento. Também eram distribuídos releases sobre os salões, que geraram uma divulgação expressiva tanto local como na grande imprensa ${ }^{86}$. Desde o I Salão, saíram desde pequenas notas, críticas e matérias em jornais como O Estado de São Paulo, a Folha de São Paulo, a revista O Cruzeiro e o Diário do Grande ABC.

Outra ação desenvolvida em várias edições foi a organização de palestras com os artistas e de visitas guiadas com alunos da rede de ensino da cidade, inclusive com a contratação de monitores para acompanhamento das escolas e fornecimento de transporte. Isso demonstra a visão dos criadores dos salões, de que estes não deveriam ser eventos fechados em si mesmos, mas ter uma amplitude maior em relação à sociedade, principalmente através do viés da educação.

${ }^{85}$ Das treze obras premiadas nessa mostra, somente nove estão na Coleção dos Salões de Arte Contemporânea.

${ }^{86}$ Dos jornais locais, podemos destacar o Jornal de São Caetano, o Jornal do Lar e O Arauto. 
No próximo capítulo procuramos desenvolver outras reflexões sobre a coleção dos salões de Salões de Caetano do Sul sob a perspectiva do colecionismo e da musealização da arte contemporânea.

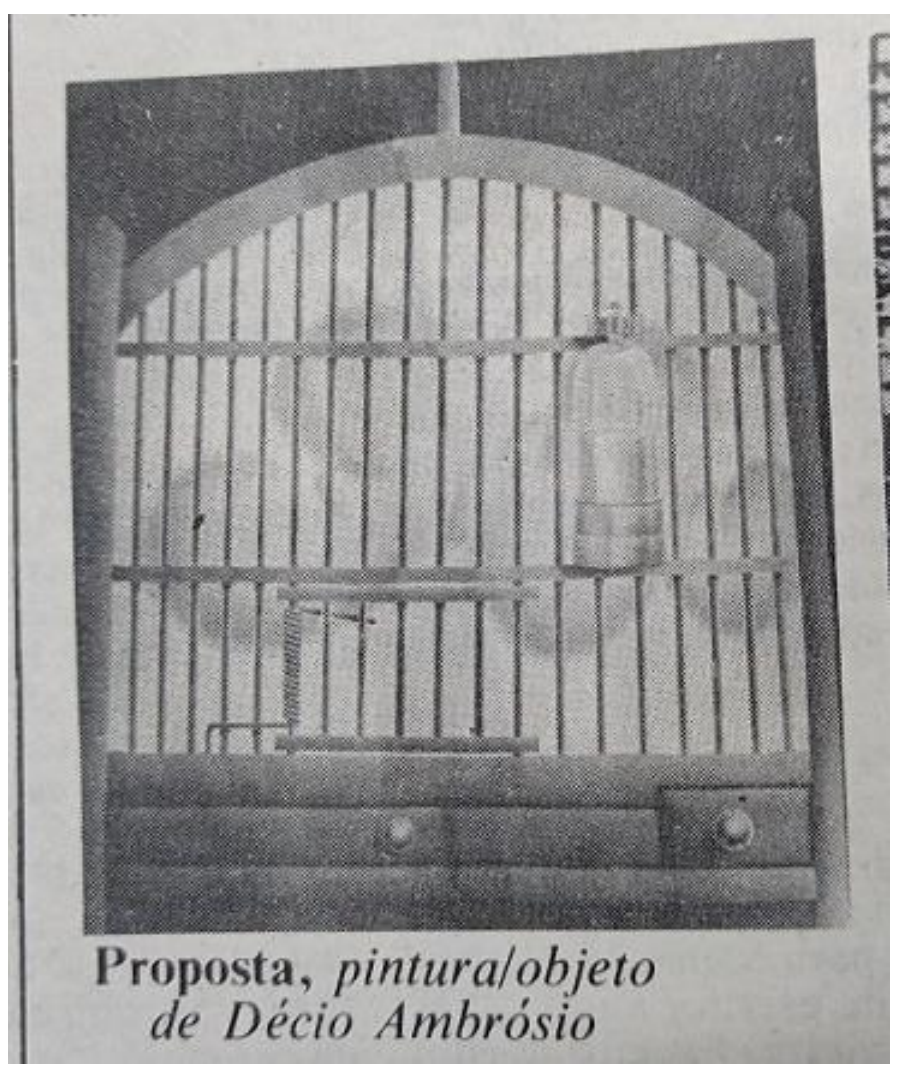

Figura 32 e 33 - Obras "perdidas" do IX Salão de Arte Contemporânea

Diário do Grande ABC, 01 ago. 1976

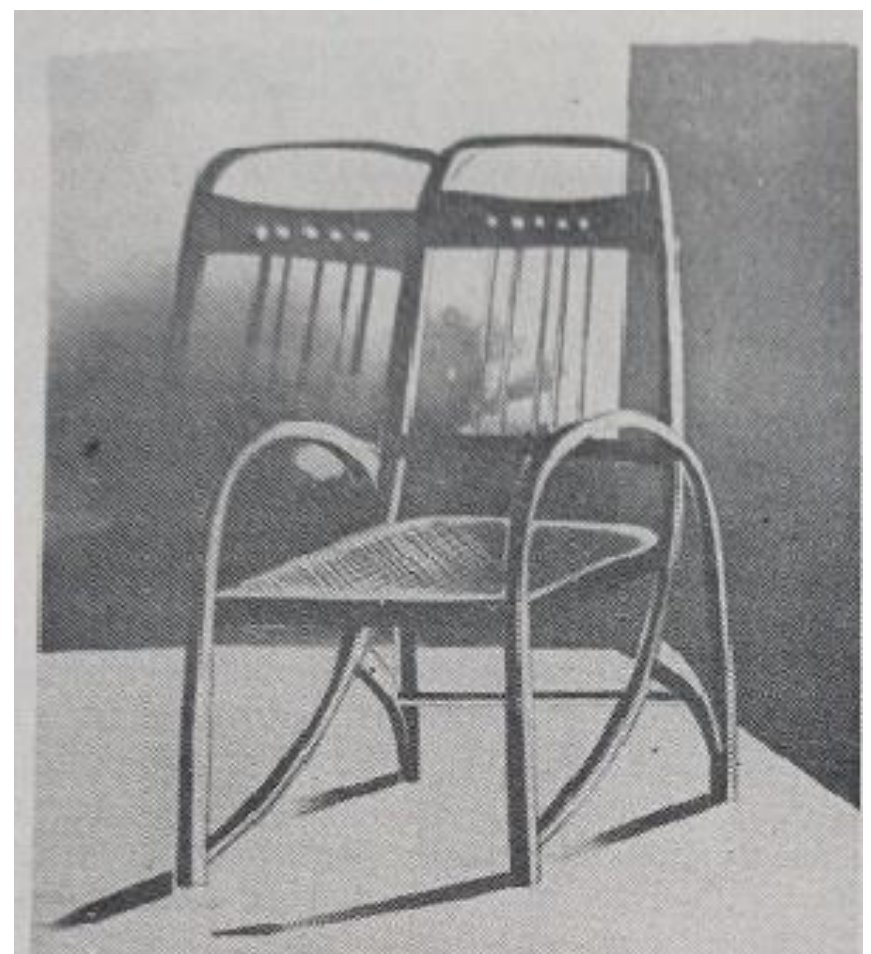

() Sol Sobre A Cadeira, de Evandro Carlos Jardim tantos artistas indicados. contando-se ns 


\title{
CAPÍTULO 3
}

\section{DA COLEÇÃO AO MUSEU}

\begin{abstract}
Se o colecionismo é uma das bases do museu que conhecemos, o que percebemos é que as tipologias museológicas - arte moderna, arte contemporânea - fazem refletir sobre tal ideia, pois, colecionar a arte de hoje representa a assunção de um 'risco' conceitual, mas também pragmático, ou seja, como ou o que colecionar: obras, conceitos, referências documentais?
\end{abstract}

(Marilúcia Bottallo)

Neste capítulo serão abordadas questões que, embora não sejam o objeto central do estudo aqui proposto, são de suma importância para que se possa compreender a abrangência dele. Assim, trataremos de aspectos relativos às coleções e ao colecionismo público de arte contemporânea.

\subsection{As Coleções}

A formação de coleções ou acervos é uma ação cujo início se perde na origem da Humanidade. O filósofo Krzysztof Pomian, em seu trabalho referencial sobre as coleções (POMIAN, 1984), apontou a existência de comportamentos colecionistas já no período chamado de Paleolítico Superior (de 2,5 milhões de anos atrás até 10.000 a.C.). ${ }^{87}$ Pomian identificou que qualquer que seja a peça que passe a integrar uma coleção, esta sofre alterações de estatuto, sendo que primeira mudança diz respeito à perda de sua utilidade original.

\footnotetext{
87 "Nos níveis correspondentes à última fase deste aquecimento, André Leroi-Gourhan tinha descoberto 'uma série de objectos de curiosidade, recolhidos pelos habitantes da gruta de Hyène (França) durante as suas deslocações. São uma grande concha em espiral de um molusco da era secundária, um polipeiro de forma esférica da mesma época, blocos de pirite de ferro de forma bizarra. Não são de modo algum obras de arte, mas que formas de tais produções naturais tenham merecido a atenção dos nossos predecessores geológicos é já o sinal de um vínculo com o estético.' (...) São então os habitantes da gruta de Hyène em Arcy-sur-Cure que detêm, até prova em contrário, o título de primeiros colecionadores conhecidos." POMIAN, 1984, p.70).
} 
E é assim com cada coisa, que acaba neste mundo estranho, onde a utilidade parece banida para sempre. Não se pode, com efeito, sem cometer um abuso de linguagem, alargar a noção de utilidade a ponto de a atribuir a objetos cuja única função é a de se oferecerem ao olhar: às fechaduras e às chaves que não fecham nem abrem porta alguma; às máquinas que não produzem nada; aos relógios de que ninguém espera a hora exata. Ainda que na sua vida anterior tivessem um uso determinado, as peças de museu ou de coleção já não o têm. (POMIAN, 1984, p. 51)

A segunda característica foi mencionada acima: a função principal das peças de coleções e de acervos de museus é serem "expostas ao olhar". Essa nova função não se confunde com o ato de decorar, pois isso "significa quebrar a monotonia das paredes vazias que já existem para torná-las agradáveis. Pelo contrário, nos museus e nas grandes coleções particulares levantam-se ou arranjam-se paredes para aí dispor as obras". (POMIAN, 1984, pp. 51-52) Além disso, apesar de estarem expostas, essas peças passam a ser cercadas de cuidados para reduzir ao mínimo os riscos de desgastes e de acidentes que possam vir a sofrer, passando a ser objeto de ações de conservação e restauro que possam garantir sua integridade e longevidade.

Também de forma contraditória, as peças que foram retiradas do 'circuito das atividades econômicas' adquirem uma nova cadeia de valores, inclusive comerciais, na medida em que existe um mercado onde elas circulam "atingindo por vezes preços astronômicos." Partindo desses pressupostos, Pomian define seu objeto de estudo:

É, portanto, possível circunscrever a instituição de que nos ocupamos: uma coleção, isto é, qualquer conjunto de objetos naturais ou artificiais, mantidos temporária ou definitivamente fora do circuito das atividades económicas, sujeitos a uma proteção especial num local fechado preparado para esse fim, e expostos ao olhar do público. (POMIAN, 1984, p. 53)

Outro fator observado pelo autor diz respeito às motivações que levavam certos indivíduos a uma propensão a acumular peças de coleção, tais como o prazer estético e a aquisição de conhecimentos históricos e científicos. Mas, somado a esses fatores, observa que as coleções representam algo "precioso", que thes confere um valor de troca em um mercado criado ao seu redor, conferindo prestígio aos seus possuidores. Além disso, criam também (e esse é um ponto que interessa ao nosso estudo sobre colecionismo público) uma "pressão exercida sobre o Estado para que torne possível o acesso a estes bens àqueles que não podem comprá-los nem [fruir] o prazer estético, nem os conhecimentos históricos e científicos, nem o 
prestígio" (POMIAN, 1984, p. 54). Conseguimos identificar aí um dos fatores que levaram à criação dos mais diversos tipos de coleções públicas e de museus.

Essa perspectiva nos remete também ao pensamento de Eunice Ribeiro Durhan que identifica a imprescindibilidade da "criação cultural de um patrimônio comum e de uma identidade própria" para a organização, funcionamento e legitimação do Estado-Nação ${ }^{88}$ (1984, p. 44).

Outro ponto de interesse do estudo de Pomian é que o autor verificou que todos os objetos que compõem as coleções "desempenham uma função de intermediários entre os espectadores e um mundo invisível de que falam os mitos, os contos e as histórias" (POMIAN, 1984, p. 67).

Ora, a partir do Paleolítico superior, o invisível encontra-se, por assim dizer, projetado no visível, pois desde então ele está representado no próprio interior deste por uma categoria específica de objetos: as curiosidades naturais e também tudo aquilo que se produz de pintado, esculpido, talhado, modelado, bordado, decorado. Por outras palavras, surge uma divisão no próprio interior do visível. De um lado estão as coisas, os objetos úteis, tais como podem ser consumidos ou servir para obter bens de subsistência, ou transformar matérias brutas de modo a torná-las consumíveis, ou ainda proteger contra as variações do ambiente. Todos estes objetos são manipulados e todos exercem ou sofrem modificações físicas, visíveis: consomem-se. De um outro lado estão os semióforos, objetos que não têm utilidade, no sentido que acaba de ser precisado, mas que representam o invisível, são dotados de um significado; não sendo manipulados, mas expostos ao olhar, não sofrem usura. A atividade produtiva revela-se, portanto, orientada em dois sentidos diferentes: para o visível, por um lado; para o invisível, por outro; para a maximização da utilidade ou para a do significado. As duas orientações, embora possam coexistir em certos casos privilegiados, são, todavia, opostas na maior parte das vezes. (POMIAN, 1984, p. 67)

A partir deste ponto, compreendem-se as relações da utilidade e do significado dos objetos. Podemos ter coisas com utilidades, mas sem significado, semióforos sem nenhuma utilidade e objetos que podem ser ao mesmo tempo coisas úteis e semióforos. Compreende-se também a necessidade de um observador para essas percepções se realizarem, porque é através desses objetos que os indivíduos mantêm relações com ambientes visíveis ou invisíveis. (POMIAN, 1984) O autor ressalta também a relação entre utilidade e significado na valorização

88 "A verdade é que um Estado Nacional não se organiza a não ser através da criação cultural de um patrimônio comum e de uma identidade própria. Não tem outro modo de criar uma sociedade a não ser através disto. O Estado faz isto, o faz, em grande parte, em benefício das classes dominantes, mas a ideia de que o Estado faça é uma ideia que não se pode eliminar. Como as nações são organizadas pelo Estado, e a nação, só pode funcionar através de um patrimônio comum (que é o que dá ideia de nação) que legitima o Estado, é necessário esse processo. O Estado faz isso mesmo que não queira, e não vejo outro modo de ter um Estado Nacional sem isso. Nós podemos dizer que devemos lutar politicamente para que isso seja menos espoliativo, menos violento e que não implique a destruição de diversidades culturais existentes." (DURHAN 1984, p. 44). 
dos objetos, apontando que quanto maior a sua carga de significado maior o valor do objeto. É nesse sentido que se destacam as obras de arte como semióforos por excelência.

Uma terceira categoria de semióforos que, sem ser nova, acede a partir do
século XV a uma dignidade que não tinha antes, é constituída por quadros e
geralmente por obras de arte modernas. O novo estatuto das obras de arte
baseia-se na sua vinculação à natureza concebida como uma fonte de
beleza e, portanto, como única capaz de dar a um objeto produzido pelos
homens os traços que lhe permitem durar; com efeito, as obras dos antigos
que sobreviveram aos estragos do tempo não podem ser devedoras senão
da natureza. [...] Um grande debate concerne especialmente o lugar da
'natureza' a respeito da oposição do visível e do invisível. Mas, qualquer que
seja a maneira em que se a conceba, e quaisquer que fossem as
divergências sobre o papel da arte (que, segundo uns, deve aplicar-se
apenas em visualizar o invisível, enquanto que, segundo outros, pode
simplesmente representar aquilo que se vê), estava entendido que apenas a
arte permite transformar o transitório em durável. Noutros termos: o que se
representa tornar-se-á mais cedo ou mais tarde invisível, enquanto que a
imagem, essa permanecerá. (POMIAN, 1984, p. 77)

Pelas reflexões desenvolvidas por Pomian podemos compreender a complexidade por trás da formação de uma coleção e, através disso, ter um vislumbre das motivações na adoção do modelo de salões de arte com estratégia colecionista na formação de coleções de obras de arte de entes do Estado, onde a abertura a "ampla" participação de artistas poderia garantir uma representatividade da classe artística, e a seleção e escolha das obras que comporiam a coleção, estando nas mãos de especialistas, garantiria a isenção das decisões tomadas. Todos esses fatores garantiriam a legitimidade da coleção resultante e a sua representatividade enquanto patrimônio cultural do Estado.

Vale aqui pontuar algumas reservas colocadas por Aracy Amaral a respeito do papel dos salões na formação dos acervos de museus. Em primeiro lugar, a pesquisadora aponta que tal prática coloca as direções dos museus em um papel passivo onde lhes cabe apenas receber essas obras sem questionamento sobre sua pertinência em relação a suas coleções. Por outro lado, os prêmios de aquisição que chegam aos museus favorecem uma "heterogeneidade qualitativa" aos acervos, fruto da "subjetividade inevitável dos membros dos júris". O terceiro ponto diz respeito à caraterística dos salões como meio de afirmação ou acesso para os jovens artistas, sendo que uma pequena parte destes prosseguiria na carreira profissional. "Daí por que são frequentes nas coleções de nossos museus de arte contemporânea os nomes desconhecidos, e também a dificuldade, por parte das equipes técnicas, em localizar um artista, cuja carreira por vezes termina em seu 
início" (AMARAL, 2006b, p. 223), o que ocorre também com a Coleção dos Salões de Arte Contemporânea de São Caetano do Sul, onde tivemos dificuldades em localizar dados sobre biografia e carreira de alguns artistas presentes nela.

\subsection{Arte contemporânea}

O segundo conjunto de reflexões deste capítulo diz respeito ao colecionismo e à musealização da arte contemporânea. Mas, para entrarmos nesse assunto, vamos primeiramente tratar de algumas questões sobre tal arte, mesmo que esses apontamentos não tenham a intenção de delimitar ou fechar uma definição sobre o tema. Como afirmou Emerson Dionísio, "não tomo como certo que haja uma definição - por mais ampla e múltipla que qualquer uma delas ambicione ser - do que venha a ser a Arte Contemporânea" (OLIVEIRA, 2010, p. 16), mas traçar algumas delimitações sobre esse tema pode trazer elementos para uma maior compreensão das obras que compõem a Coleção dos Salões de Arte Contemporânea de São Caetano do Sul.

Refletindo sobre as dinâmicas do sistema de arte, Anne Cauquelin identificou, na "ruptura entre dois modelos apresentados, o da arte moderna, pertencente ao regime de consumo, e o da arte contemporânea, pertencente ao de comunicação" (CAUQUELIN 2005, p. 87), três figuras que ela designa "embreantes" 89 do novo regime que nos ajudam a compreender a arte contemporânea. São eles os artistas Marcel Duchamp e Andy Warhol e o galeristacolecionador Leo Castelli. Vamos mencionar alguns pontos a respeito de dois desses "embreantes" à medida que eles jogam alguma luz sobre o acervo em estudo. A respeito de Duchamp, este se destaca pela sua influência sobre a arte contemporânea.

De um lado, o número de trabalhos que the são dedicados é cada vez mais importante; de outro, ele é a referência, explícita ou não, de numerosos artistas atuais. Por quê? Porque esse artista - que declarava não sê-lo parece expressar o modelo de comportamento singular que corresponde às expectativas contemporâneas. (CAUQUELIN, 2005, p. 89)

89 'O termo 'embreante' designa, em linguística, unidades que têm dupla função e duplo regime, que remetem ao enunciado (a mensagem, recebida no presente) e ao enunciador que a anunciou (anteriormente). Os pronomes pessoais são considerados embreantes, pois ocupam um lugar determinado no enunciado, onde são tomados como elementos do código, além de manterem uma relação existencial com um elemento extralinguístico: o de fazer ato da palavra." (JAKOBSON apud CAUQUELIN, 2005, pp. 87-88) 
A atualidade de Duchamp estaria lastreada nos seguintes pontos: promover a distinção entre a esfera da arte e da estética, por não considerar mais a primeira como subordinada à segunda; a arte, não mais em conflito com as outras atividades, ao contrário, integra-se a elas; sendo um sistema de signos entre outros, e passando a ser a realidade desvelada por meio deles e constituída pela linguagem, seu "motor determinante". Daí a "importância dos jogos de linguagem e da construção da realidade; [pois] a arte não é mais emoção, ela é pensada; o observador e o observado estão unidos por essa construção e dentro dela" (CAUQUELIN, 2005, p. 90).

O rompimento de Duchamp com a prática estética da pintura representou um deslocamento do domínio da arte, que já não seria mais uma questão de conteúdos, mas sim de continentes. A obra de arte, antes única e não-reprodutível, aproxima-se da reprodução técnica. Com os ready-mades, ele sai do terreno estético do "feito à mão". Os objetos recebem valor estético e peso artístico pelo espaço onde são expostos (galeria, salão museu) ou pelos textos que se publicam sobre eles.

Em relação à obra, ela pode então ser qualquer coisa, mas numa hora determinada. O valor mudou de lugar: está agora relacionado ao lugar e ao tempo, desertou o próprio objeto. A divisão entre estética e arte se faz em benefício de uma esfera delimitada como palco, onde o que está sendo mostrado é arte. Nesse caso, o autor desaparece como artista pintor, ele é apenas aquele que mostra. Basta-lhe apontar, assinalar. A assinatura que acompanha o objeto já pronto é a única marca de sua existência, marca por sinal com frequência disfarçada: como R. Mutt assinando o mictório, Rrose Sélavy, ou ainda alguns 'acréscimos' (os ready-mades acrescentados, como Barulho secreto (1916)). (CAUQUELIN, 2005, p. 94)

Anne Cauquelin identifica que a influência de desse embreante vai ainda mais além:

Duchamp como obra contém em germe os desenvolvimentos que os
artistas que virão depois dele impulsionarão, em um sentido ou em outro: a
arte conceitual, o minimalismo, a pop art, as instalações, até mesmo os
happenings que ele tanto apreciava. Mas não é nessa sequência histórica,
nessa continuidade de desenvolvimento de um conteúdo estético que se
deve procurar a transformação de Duchamp. Seria um contra-senso [sic]
fundamental. É nas proposições axiomáticas que anunciam e fundam o
regime da arte contemporânea que seu trabalho é verdadeiramente
transformador. É nesse ponto que a esfera da arte se articula com a era da
comunicação todo-poderosa. (CAUQUELIN, 2005, p. 102) O segundo "embreante", Andy Warhol, traz uma nova relação entre arte e mercado de consumo. Se ele "é um 'artista' - e não se pode ignorá-lo como tal - é porque sua obra será dupla: de um lado, ela irá se situar no sistema mercantil, mas 
de outro, ao exibir notoriamente esse sistema, ela o criticará - Warhol faz negócios e não os esconde, o que deixa muito pouco à vontade aqueles que comentam a arte 'moderna'” (CAUQUELIN, 2005, p. 107).

Warhol transitava numa esfera que se dissocia das questões de gosto, de belo e de único. Os objetos que mostrará serão banais - o kitsch, de mau gosto objetos de consumo usual. Nas duplicatas, o remade, da mesma forma que Duchamp, trata de mostrar o que já existe. Mas, "ao ready-made 'acrescentado' de Duchamp, que permanece único e quase impossível de ser encontrado, Warhol opõe a repetição em série, a saturação das imagens e o paradoxo de uma despersonalização hiperpersonalizada" (CAUQUELIN, 2005, p.110).

Então, se Duchamp havia concedido ao local a incumbência de anunciar a mensagem "Isto é arte", renunciando assim à habilidade e à estética do gosto, afastando-se por assim dizer da cena e se preservando, Warhol, ao colocar em prática seu conhecimento das redes, abandona esse último refúgio e essa última marca da arte, que é o local de exposição, para se estabelecer no espaço inteiro das comunicações. Passa de um lugar (topos) determinado, marcado com um rótulo 'arte', ao conjunto de um circuito que ele ocupa inteiramente. A despersonalização visada vai, portanto, transformar-se em personalização desmesurada por meio da invasão do nome Warhol sobre todos os suportes. (CAUQUELIN, 2005 p. 110)

Warhol compreendeu muito cedo o sistema e passou a usar os mecanismos da publicidade para fabricar um "produto chamado Warhol". Ele coloca seu sistema de arte dentro de uma rede de comunicação.

A definição de arte como negócio e do artista como homem de negócios da
arte é uma proposição terminante, que dá seguimento às proposições de
Duchamp. Ela não parece cínica a não ser aos olhos daqueles para quem a
arte tem ainda alguma coisa a ver com a estética: o gosto, o belo e o único.
De fato, ela é não só coerente com o Warhol's system (o sistema de
Warhol), com as proposições da pop art, da arte conceitual e do
minimalismo, como portadora de uma desmistificação fundamental na qual
residem justamente os encantos da arte contemporânea, orientada segundo
os princípios da comunicação.

O percurso sonhado por Andy Warhol - passar do status de artista comercial ao de artista de negócios - está completo. No caminho, fechou-se também a definição de arte contemporânea - fora da subjetividade, fora da expressividade - na qualidade de sistema de signos circulando dentro de redes. Definição estrita, quase insuportável em seu rigor. (CAUQUELIN, 2005, p. 120)

Conseguimos perceber através dessas caracterizações dos "embreantes" identificados por Anne Cauquelin os pontos de inflexão que lastrearam os movimentos artísticos que marcaram as décadas nas quais foram produzidas as obras do acervo em estudo. Com relação ao estabelecimento da noção do que seria a arte contemporânea, Catherine Millet aponta os conservadores de museus como 
os primeiros a traçar fronteiras entre o moderno e o contemporâneo, motivados por razões bastante pragmáticas:

[...] antes mesmo de se depararem com estas preocupações deontológicas, os conservadores foram confrontados com um problema muito concreto. Os que pertencem às instituições mais importantes, já largamente providas de obras do início do século e cujas coleções continuam a ser enriquecidas, tiveram de empreender a classificação dessas coleções. E aqueles que asseguraram o arranque dessas novas instituições inteiramente voltadas à arte contemporânea, tiveram de definir o seu campo de competência, relativamente a museus que, já há vários decénios, seguiam a evolução da arte moderna. Para uns como para outros, a questão é: "Onde termina a arte moderna e onde começa a arte contemporânea?" (MILLET, 1997, p. 14-15)

Ao analisar um inquérito realizado entre esses conservadores e pessoas relacionadas ao campo das artes, ela destaca algumas conclusões. O início da arte contemporânea seria em algum ponto entre 1960 e 1969, segundo a maior parte dos participantes da pesquisa.

No decurso dos anos 60, impuseram-se a Pop art*, o Novo Realismo*, a op art" e a arte cinética", a minimal art e o color field painting; o Fluxus* enxameou, os happenings proliferaram; no final do decénio, surgiram a arte conceptual", o anti-form", a arte povera", a land art", a body art", o SupportSurface..., inúmeras formas de arte que recorrem a todo o tipo de materiais heteróclitos, objetos fabricados, matérias naturais e perecíveis, e até ao próprio corpo do artista. Todos os processos foram permitidos, incluindo os mais desconcertantes, os mais provocadores, os mais incompreensíveis, tomando o artista o lugar do seu público ou, pelo contrário, fugindo dele para ir esculpir no próprio solo de um deserto longínquo; um público que foi sacudido entre obras fazendo apelo às suas reações instintivas e outras obrigando, pelo contrário, a seguir complexos raciocínios teóricos; um público confrontado com obras invadindo o espaço, enquanto que era forçado a imaginar outras totalmente invisíveis... Os vanguardistas do início do século haviam já, é certo, abalado furiosamente as convenções e brincado aos aprendizes de feiticeiro, mas durante este decênio eufórico essas práticas generalizaram-se, gozando de uma área de liberdade, de que não tinham certamente beneficiado os pioneiros. É nesta área de liberdade, que se continua a desenvolver alegremente a arte de hoje. (MILLET, 1997, p. 15-16)

Outra questão apontada por Millet chama atenção, pois, ao mesmo tempo em que os anos 60 presenciaram a "eclosão" de movimentos de vanguarda, eles marcaram também uma "abertura social" para esses movimentos. Os seus protagonistas gastaram menos tempo para fazer-se reconhecer pelo mercado e pelas instituições do que Cézanne para se fazer admitir no Salão. Leo Castelli diz ter exposto Roy Lichtenstein na sua galeria, imediatamente após tê-lo conhecido em 1961, embora tenha achado "bizarros" os seus quadros realizados como bandas desenhadas (MILLET, 1997, p. 18). 
Em suas reflexões, Millet aponta outros elementos para composição do que seria arte contemporânea. Ela afirma que a arte se tornou contemporânea quando passou a tratar da vida cotidiana. Além da estetização do cotidiano, havia artistas que pretendiam mostrar que essa mesma vida cotidiana continha imagens que mereciam atenção dos estetas. Portanto, não haveria razão para "não se utilizar nas obras de arte, qualquer outro objeto produzido industrialmente." (MILLET 1997:24)

Mas a arte dos anos 1960 não trouxe somente novos temas, há também uma proliferação de estilos - ou não estilos -, o que autorizou a autora a dizer que, no período do segundo pós-guerra haveria tantos estilos quanto pintores existentes, e que a essa estética individualizada se sucederia uma estética impessoal, quase coletiva. Em decorrência disso, Millet aponta para uma dessacralização do artista, que deixa de ser um ser "excepcional com o qual não nos poderíamos comparar" para ser alguém "como nós"

Somando-se a esses apontamentos que nos auxiliam a visualizar e compreender o campo da arte contemporânea, Elisa de Noronha Nascimento faz em seu trabalho uma colocação que, para nosso estudo, completa a questão. Segundo ela, é possível identificar, a partir dos anos de 1950, uma distinção entre o moderno e o contemporâneo, sendo o primeiro "definido como algo mais que um conceito temporal e a designar não apenas uma arte mais recente, adquirindo um significado estilístico, 'uma noção de estratégia, estilo e ação'”, e o contemporâneo "passou a designar algo mais que a arte do momento presente, 'a arte contemporânea passou a significar arte produzida com uma determinada estrutura de produção nunca vista antes (...) em toda história da arte" (NASCIMENTO, 2014, p. 4).

Voltando mais uma vez ao caso de salões de arte de Campinas, a análise desenvolvida por Renata Zago parece se aplicar perfeitamente ao caso de São Caetano do Sul.

No início dos anos 1960, o eixo do debate artístico deslocou-se das questões estéticas para as questões políticas e sociais, dando início a uma preocupação formal comprometida com a realidade imediata.

No cenário mundial, vários movimentos retomaram a figuração em diferentes vertentes, havendo grande receptividade no âmbito brasileiro, destacando-se aqui a influência da Pop Art norte-americana e do Nouveau Réalisme francês. Dessa maneira, alguns dos artistas brasileiros que já haviam assimilado as experiências concretas e neoconcretas dialogavam agora com as novas tendências figurativas internacionais, inserindo-as na

90 Qualquer um poderá perceber que é, a partir de agora, possível tornar-se artista, sem se ter frequentado uma academia, sem possuir sequer um dom particular. (MILLET, 1997, p. 30) 
realidade social, política e cultural que vivenciavam no Brasil de maneira crítica e consciente. Voltaram-se para a temática urbana e para a percepção do cotidiano e propuseram uma relação provocativa e interativa com o público.

Assim, nas palavras de Walter Zanini, "os novos realismos haviam ganhado espaços nos salões de Campinas e São Paulo. Múltiplas formas de sensibilidade na sua abordagem puderam ser vistas nos certames anuais dedicados às novas gerações". Essa transição do abstracionismo à figuração bem como a representação figurativa inspirada no cotidiano e na situação social e política brasileira pode ser percebida na produção exposta nos SACCs dos anos 1960.

Em reportagem publicada pelo jornal de Campinas Correio Popular há uma descrição superficial das obras expostas no I SACC: "as mais modernas manifestações da pop-art, da ingenuidade dos primitivistas, do agonizante desespero dos surrealistas, passando ainda pelo concretismo, abstracionismo, realismo fantástico, tachismo [...]". (ZAGO, 2007, p. 23)

Mesmo sem que se tenha feito um estudo das obras da Coleção dos Salões, podemos identificar a presença linguagens artísticas que se aproximam dos movimentos acima apontados - o pop art, o surrealismo, o abstracionismo, o realismo fantástico, a figuração, os temas políticos. Assim, reconhecemos nessa coleção um acervo representativo das manifestações artísticas das décadas de 1960 e 1970. Como já afirmamos, não estamos em busca de uma definição do que é arte contemporânea, mas levantando elementos que possam auxiliar na identificação das obras da Coleção dos Salões e, de alguma forma, enriquecer as informações sobre elas. É certo que esse acervo merece estudo mais aprofundado. Esperamos poder fornecer aos futuros pesquisadores mais elementos do que tínhamos no início desta caminhada.

Por fim, esperamos que as informações, reflexões e apontamentos desenvolvidos neste trabalho possam dar suporte aos futuros dirigentes da Pinacoteca Municipal de São Caetano do Sul na continuidade do tratamento do acervo e no desenvolvimento de políticas de gestão e do plano museológico da instituição.

\subsection{Colecionando Arte Contemporânea}

Quando tratamos da formação da Coleção dos Salões de Arte de São Caetano do Sul é necessário refletir sobre o colecionismo da arte contemporânea no âmbito dos museus a ela dedicados. Altshuler trata essa questão a partir do início do século XIX, "quando a noção do que é contemporâneo iria tornar-se sinônimo do que é moderno" (2010, p. 67). A própria noção de museu instituída no século XVIII 
estabelecia que fariam parte dos acervos as obras que tivessem resistido ao "teste do tempo" uma vez que os julgamentos artísticos "são notoriamente falíveis."

[...] mas há uma presunção básica sobre o colecionismo em museus, de que no longo prazo desenvolver-se-á um consenso entre os especialistas, um acordo que identificou e continuará a identificar os grandes artistas e suas obras-primas. Mas se os museus colecionam e exibem obras que resistiram ao teste do tempo, isto pareceria excluir obras de arte contemporâneas ou recentes, sobre as quais não houve tempo suficiente para o desenvolvimento de um consenso a longo prazo. (ALTSHULER, 2010, p. 68)

Apesar das discussões sobre a pertinência da arte contemporânea (aqui entendida como a arte da atualidade) nos museus ter perdido sentido há muito tempo, ela suscitou grande debate na década de 1920.

[...] a arte contemporânea que foi contestada durante os anos de 1920 era a arte de vanguarda, algo bastante diferente da arte de artistas vivos que os museus começaram a colecionar no século XIX. Pois agora existe um filtro ideológico pelo qual a arte contemporânea deve passar, o da arte "de ponta" e "avançada", vista através da lente da busca modernista pelo novo. (ALTSHULER, 2010, p. 68)

Durante o período de constituição, depois da Revolução Francesa, dos grandes museus nacionais, que exibiam basicamente obras do passado, já se observava a criação de instituições vinculadas ao "orgulho nacional", dedicados a apresentar "conquistas artísticas nacionais", ou seja as obras dos artistas vivos.

Esse foi o caso da conversão do Palácio de Luxemburgo no Musée des Artistes Vivants, em 1818.

Com o Louvre reservado para as obras-primas do passado, um novo sistema era necessário para que o Estado pudesse adquirir arte recente e, portanto, demonstrar o compromisso em andamento da França com seus artistas. A solução foi que o Luxemburgo se tornasse efetivamente um musée de passage, uma área de hospedagem para obras que poderiam passar ao Louvre dentro de cinco ou dez anos após a morte de um artista. Este compromisso nacional foi logo expresso pela compra, por parte do Estado, de pinturas nos Salões anuais, obras compradas para 0 Luxemburgo e, cada vez mais, para o sistema de museus provincianos que estava em expansão. Em geral estas aquisições eram conservadoras, e foi somente em 1896 que importantes pinturas impressionistas foram admitidas no Museu de Artistas Vivos.

Apesar de alguns poucos momentos progressistas no Luxemburgo, a identificação institucional do contemporâneo com o "novo" modernista teve origem não na França, mas na Alemanha. Pois foi na Alemanha que essas obras foram colecionadas pela primeira vez por museus em número significativo e que museus se comprometeram pela primeira vez com o que chamaríamos de "arte contemporânea". Mas com comitês institucionais de aquisição controlados por artistas estabelecidos, foram necessárias compras radicais feitas por alguns inovadores diretores de museus para mudar o curso do colecionismo de museus na Alemanha. (ALTSHULER, 2010, p. 71) 
A criação do MoMA, em Nova York, foi um marco para o desenvolvimento do museu de arte contemporânea modernista nos Estados Unidos da América. Altshuler destaca, no entanto, uma experiência museológica que o antecedeu, a Société Anonyme de Katherine Dreir, "uma sociedade de exposição e protomuseu criada e administrada em estreita colaboração com Marcel Duchamp"91 (ALTSHULER, 2010, p. 74).

Para museus de arte moderna - como os de Dreier e Barr - não havia qualquer problema conceitual do tipo que mencionei antes. Explicitamente criados para colecionar e apresentar obras contemporâneas - pois nos anos de 1920 "moderno" significava "contemporâneo" - eles não precisavam se preocupar com que suas coleções tivessem resistido a qualquer teste de tempo. Entretanto, havia um problema em relação à atualidade de suas obras, pois não é, de modo algum, claro o quão contemporâneo o contemporâneo deve ser. (...)

A visão de Barr era a de que o museu não deveria manter obras por mais de cinquenta ou sessenta anos após terem sido criadas, e um acordo de 1947 entre as duas instituições pareceu antecipar que cada obra na coleção do MoMA seria algum dia transferida para o Metropolitan Museum. Não é de surpreender que os fiéis comissários do MoMA logo começassem a procurar uma maneira de contornar este acordo. Preocupações com doações futuras e temor de perder seus bens mais valiosos - seus "Cézannes", "Van Goghs" e "Picassos" - levaram, em 1953, a uma recusa oficial da orientação de transferir a coleção do MoMa, peça a peça, para outras instituições. Com esta ação, o MoMA perdeu a singularidade de seu conceito de colecionismo e aderiu ao contingente de instituições tradicionais. Apesar de seu foco em Arte Moderna, isto definiria sua coleção em torno da prática de adquirir obras-primas e mantê-las perpetuamente. (ALTSHULER, 2010, p. 75)

Esse modelo revisado do MoMA se tornou o padrão de colecionismo de arte contemporânea em museus, com a exceção de um museu: o New Museum of Contemporary Art. Fundado em 1977, esse museu levou a fundo seu compromisso com a contemporaneidade, abrindo mão da permanência de seu acervo, criando-se uma "coleção semi-permanente". "A política era tentar adquirir ao menos uma obra de cada uma das maiores exposições, e cada uma das peças deveria ser retida por no mínimo dez anos e no máximo vinte." (ALTSHULER, 2010, p. 76). Com a maturidade institucional do New Museum, esse "plano relativamente utópico" tornouse cada vez mais problemático e essa política de colecionismo passou a ser reavaliada.

Apesar de essa ser uma questão superada nos dias atuais, decidimos tratála aqui para demonstrar a complexidade do tema para as instituições museológicas,

${ }^{91}$ Fundada em 1920, pelos artistas Katherine Dreir, Marcel Duchamp e Man Ray, a Société Anonyme adquiriu significativas coleções contemporâneas e montou exposições importantes antes da criação do MoMA. (ALTSHULER, 2010) 
que se define a partir dos acervos que contêm e dos processos de musealização que aplicam a eles.

\subsection{Arte Contemporânea e Museus}

Por fim, vamos retomar as questões sobre a musealização desenvolvidas na Introdução deste trabalho, a partir dos acervos de arte contemporânea.

Em sua tese sobre a musealização da arte contemporânea, Elisa de Noronha Nascimento desenvolve importantes reflexões sobre essa questão. (NASCIMENTO, 2013) ${ }^{92}$. Partindo da "crise de identitária" dos museus, ocorrida no início dos anos 1970, que provocou o repensar das instituições museológicas e criou o movimento da Nova Museologia, Nascimento expôs como esse momento se refletiu nos museus de arte, particularmente nos novos museus dedicados à arte contemporânea.

Circunscrevendo essa discussão em torno do museu de arte contemporânea e de uma maneira mais abrangente em torno de sua matriz, o museu de arte, sua crise existencial ou identitária vem sendo manifesta e muitas vezes incitada por uma série de estudos teórico-práticos preocupados, por um lado, em deslindar suas assunções e determinações institucionais e, por outro, em desenvolver e apresentar estratégias de (auto)reflexão. Entre esta produção destacam-se os estudos de HooperGreenhill (2001b) sobre a origem moderna do museu de arte público, caracterizando-o como um instrumento científico de conservação, classificação e exibição dos testemunhos do saber e da criação humana, como um instrumento de aprendizagem e de exaltação dos valores históricos nacionais, consolidando-se internacionalmente durante o século XIX e XX como uma entidade de função pública e social e como um aparelho disciplinar classificando e controlando o espaço, as coisas, moldando o corpo e o conhecimento; de Crimp (2005) sobre o museu de arte como um espaço de exclusões e confinamentos e o seu papel na determinação da produção e da recepção da arte na cultura do modernismo; de Duncan (1995) e Duncan e Wallach (2004), que apresentam o museu como um complexo fenômeno arquitetônico e ideológico, como um espaço separado, como uma zona liminar de espaço e tempo ritualístico no qual os visitantes, retirados das atribuições de suas vidas práticas diárias, abrem-se a uma qualidade diferente de experiência e atuação, interiorizando os valores e as crenças inscritos no script arquitetônico e expositivo do museu; de Preziosi (2006a, 2006b) sobre o museu como o principal instrumento moderno de construção e transformação da identidade de indivíduos e Nações, como uma tecnologia epistemológica para a produção de conhecimento e fabricação de mundos. ${ }^{93}$ (NASCIMENTO, 2013, p. 34)

92 Elisa de Noronha Nascimento apresenta em sua tese de doutoramento um estudo sobre museus de arte contemporânea, mais especificamente, sobre a musealização da arte contemporânea como um processo de atualização, adesão, ruptura, afirmação e reorientação de discursos e práticas institucionais. (NASCIMENTO, 2013)

${ }^{93} \mathrm{Na}$ citação, a autora refere-se às seguintes publicações: HOOPER-GREENHILL, E. Museums and the Shaping of Knowledge, London: Taylor \& Francis, (2001b); CRIMP, D. Sobre as ruínas do museu, 
A autora salienta que o museu de arte contemporânea, enquanto tipologia de museu, tem uma existência de quase duzentos anos e, "a princípio, poder ser entendido como um gênero de museu caracterizado pela natureza de sua coleção, por colecionar arte contemporânea, mas também, por conservá-la, categorizá-la, investigá-la, torná-la inteligível."

Porém, quando a própria arte contemporânea, seja pelas características de
seus materiais e processos, seja pela sua pluralidade de momentos e
práticas, tensiona e problematiza funções e conceitos sistematicamente
estabelecidos ao longo dos últimos dois séculos - arte, artista, público,
originalidade, autoria, autenticidade, permanência, visualidade, etc. -,
qualquer noção segura de como musealizá-la é também suspensa.
(NASCIMENTO, 2013, p. 34)

Retomando a questão colocada por Altshuler do conflito entre museu e a arte contemporânea, ${ }^{94}$ Nascimento aponta que apesar dessa tradicional associação ser atualmente contestada, continua sensivelmente subjacente às práticas museológicas e ao mundo da arte. "Assim, a arte atual ao ser incorporada à coleção de um museu - ou em menor medida, ao ser exposta em um museu - seria valorizada em projeção, situando-se em uma história antecipada da arte" (NASCIMENTO, 2013, p.53). A partir dessa observação, a autora conclui que os processos de musealização não são apenas ligados "a construção e preservação de um passado - seus objetos, fatos, circunstâncias - mas também a construção e preservação de um presente - com seus critérios e valores -, da relação que temos hoje com as coisas que atualmente acreditamos nos constituir enquanto seres humanos, indivíduos sociais, históricos e culturais" (NASCIMENTO, 2013, p.54).

Entendendo que o processo de musealização 95 "consiste em alterar o estatuto de um objeto, transformá-lo em um objeto de museu através de uma

São Paulo: Martins Fontes, 2005; DUNCAN, C. Civilizing Rituals. London and New York: Rotledge, 1995; DUNCAN, C., WALLACH, A. The universal survey museum in CARBONELL, B. (ed.). Museum studies: an anthology of contexts, Malden, Mass.: Blackwell Publishing, 2004, pp. 51-70; PREZIOSI, D. Art history and Museology: rendering the visible legibl in MACDONALD, S. (ed.). A companion to museum studies, Oxford: Blackwell, 2006a, pp.50-63.; PREZIOSI, D. Philosophy and the Ends of the Museum, in GENOWAYS, H.H. (ed.), Museum Philosophy for the Twenty-first Century, Oxford: AltaMira Press, 2006b, pp.69-78.

${ }_{94}$ Entendimento de museu como a instituição que preserva obras que resistiram ao teste do tempo e que as contextualiza em uma narrativa histórica de arte na qual as "obras novas" não poderiam ter lugar definitivo (NASCIMENTO, 2013, p.53).

${ }_{95}$ "Partindo de um ponto de vista científico e social, a musealização pode ser entendida como um conjunto de procedimentos que possibilita que uma coisa se torne testemunho material (ou imaterial) do homem e de seu entorno e, consequentemente, objeto de preservação, estudo e exposição; como um processo através do qual uma coisa é selecionada, extraída de seu meio de origem natural ou cultural e imbuída de um estatuto museal (MAIRESSE, et al., 2009) ao ser inserida num contexto particularmente conceitual e simbólico materializado num modelo institucional específico: o museu por excelência (MENSCH, 1992). Como um processo através do qual uma coisa, para além de ser 
operação política - orientada por critérios e valores culturais, sociais, econômicos -, científica - a conservação dos objetos -, e de uma operação estética - a elaboração de sistemas de construção de significados", Nascimento ressalta que tais operações implicam distorções, deturpações e reestruturações do objeto musealizado (NASCIMENTO, 2013, p. 55).

Dentre essas possíveis implicações, a autora destaca a descontextualização do objeto musealizado, nessa ação duas dimensões interconectadas: a física e a conceitual. Descontextualizar um objeto significa retirá-lo de seu contexto primário e da rede de relações onde é dotado de valores como de uso, econômico etc., e integrá-lo em um contexto museológico que produz a sua desfuncionalização e isolamento de seu contexto original e produz a sua ressignificação em detrimento de uma valorização, seja ela documental, representacional ou contemplativa.

Citando um trabalho de Alpers, Nascimento aponta outro efeito implícito à descontextualização do objeto, denominado museum effect "um modo de ver sob o qual os objetos são expostos no museu e que os transforma em objetos visualmente interessantes, influenciando nas estratégias de interpretação dos visitantes: as legendas, os textos, a iluminação etc." Este autor observa que, à medida que o museum effect estabelece determinados parâmetros de interesse visual, ele transforma objetos da cultura material em objetos de arte. Os próprios objetos artísticos sofreriam a mesma pressão do museum effect pela maneira que são situadas e iluminadas, por exemplo. (NASCIMENTO, 2013, p. 56)

André Malraux é outro autor que trata da transformação do modo de ver a obra de arte a partir de sua musealização.

O papel do museu na nossa relação com as obras de arte é tão considerável que temos dificuldade em pensar que ele não existe, nunca existiu, onde a civilização da Europa moderna é ou foi ignorada; e que existe entre nós há menos de dois séculos. O século XIX viveu dos museus; ainda vivemos deles, e esquecemos que impuseram ao espectador uma relação totalmente nova com a obra de arte. Contribuíram para libertar da sua função as obras de arte que reuniam, para transformar em quadros até mesmo os retratos. Se o busto de César, a estátua equestre de Carlos Quinto, ainda são César e Carlos Quinto, o duque de Olivares é simplesmente Velázquez. Que nos importa a identidade do Homem do Capacete, ou do Homem da Luva? Chama-se Rembrandt e Ticiano. O retrato começa por deixar de ser o retrato de alguém. Até o século XIX, todas as obras de arte eram a imagem de algo que existia, antes de serem obras de arte. Só aos olhos do pintor a pintura era pintura; e, muitas vezes,

simplesmente transportada para um museu, é transformada em objeto de museu (PREZIOSI, 2006a, p. 50) assumindo funções e significados consoantes à natureza da própria instituição." (NASCIMENTO, 2013, p. 54) 
era também poesia. $\mathrm{E}$ o museu suprime de quase todos os retratos (mesmo sendo ele de um sonho), quase todos os modelos, ao mesmo tempo que extirpa a função às obras de arte: não reconhece Paládio, nem santo, nem Cristo, nem objeto de veneração, de semelhança, de imaginação, de decoração, de posse; mas apenas imagens de coisas, diferentes das próprias coisas, e retirando desta diferença específica a sua razão de ser. (MALRAUX, 1965, p. 9-10)

Sobre a descontextualização do objeto artístico e sua recontextualização ao entrar no museu, Nascimento cita ainda David Carrier e seu conceito de museum skepticism. Nele a questão é apresentada de um ponto de vista dual: de um lado, a "arte ao entrar no museu manteria plenamente sua identidade prévia (...); do outro, a arte, mais especificamente a arte antiga, não sobreviveria a tal metamorfose." (NASCIMENTO, 2013, pp. 57-58).

Outro ponto em relação à musealização de arte contemporânea, principalmente ligado às questões de conservação, como foi apontado por Millet.

Sabe-se que a arte contemporânea designa, globalmente, esses objetos intransportáveis, ou imperceptíveis, precários, por vezes que sujam, que não se sabe muito bem por que lado considerar. Ao que se acrescenta que, em muitos casos, o conservador tem que ser uma espécie de intérprete. Quando entram na composição das obras, objetos que têm de ser renovados, ou montados de forma diversa em função de um novo espaço de exposição, o conservador por muito precisas que sejam as instruções fornecidas pelo artista, terá, inevitavelmente, de tomar decisões por sua livre iniciativa. (MILLET, 1997, pp. 45-46)

Como já abordado anteriormente, a musealização está intrinsicamente ligada ao processo de preservação, na promoção da permanência de obras em seus aspectos materiais e imateriais. Muitas vezes, esse aspecto é colocado em xeque por obras que têm como linguagem poética questões ligadas à impermanência.

Segundo Glenn Wharton, a arte contemporânea desafia os valores implícitos da conservação, pois os conservadores são comprometidos com a prolongação da vida física dos objetos perante as mudanças inevitáveis e são contrariados pela arte conceitual e outras que questionam as noções de permanência empregando materiais efêmeros.

Eles (os conservadores) trabalham com curadores e outros para identificar significados simbólicos investidos nas coleções de museu. Sua missão é conservar não somente o objeto, mas seu significado cultural para as gerações do presente e do futuro. O significado cultural nas belas artes na maior parte reside tipicamente na intenção conceitual do artista. Assim um objetivo da conservação das belas artes é preservar a intenção do artista impedindo a mudança física. Os conflitos surgem quando a intenção do artista é contrária à doutrina da preservação. (WHARTON, 2010, p. 163, tradução nossa) 
Seguindo esse raciocínio, Wharton assinala dois valores centrais da conservação que entram em conflito com os objetivos da arte contemporânea, a "ética da preservação" e o respeito à "verdadeira natureza" do objeto.

O ponto é que alguns trabalhos de arte contemporânea parecem condenados a se desintegrar por causa da escolha ruim de meios ou incompatibilidade de materiais.

Assim como alguns artistas contemporâneos sem saber ameaçam a
longevidade pela sua seleção de mídias, outros fazem comprometimentos
deliberados. Materiais efêmeros e justaposições instáveis podem comunicar
significados simbólicos que expressam a intenção do artista, mas também
conscientemente levam à autodestruição. (WHARTON, 2010, p. 167,
tradução nossa)

Outras questões de conservação são colocadas quando instalações temporárias e arte performática entram para as coleções permanentes. Segundo o autor, a conservação se torna um caso de "arquivamento de materiais secundários" e "documentação de elementos essenciais do trabalho para uma reinstalação, incluindo materiais substitutos aceitáveis e tolerância a mudanças no ambiente de exposição". Essas questões têm levado os museus a reconsiderarem suas políticas de conservação, em alguns casos "imagens que registram a deterioração dos materiais originais são preservadas ao invés do objeto em si” (WHARTON, 2010, p. 172, tradução nossa)

A respeito desse assunto, Isis Baldini Elias (2016) levanta duas questões relevantes para nossa reflexão. A primeira diz respeito ao que ela chama de "colecionismo indiscriminado", que é gerado pela falta de uma política de aquisições clara por parte das instituições. Através dele, uma grande quantidade de obras descontextualizadas ou sem relevância artística para a coleção onde são inseridas nos acervos, comprometendo parte da verba da instituição em esforços na sua conservação e ampliação de reservas técnicas, sem trazer retorno à sociedade, já que essas obras quase nunca são expostas.

A segunda, que ela denomina "musealização excessiva", ocorre na aplicação dos princípios da preservação consagrados no campo museal para "tornar perene o que é materialmente e ideologicamente efêmero". Esses processos seriam então "pautados na incorporação sem reflexão, de práticas estabelecidas para os museus históricos, na valorização constante dessas obras, no culto ao objeto, ou ao 
que sobrou dele, e no despreparo teórico-crítico dos profissionais dos museus para lidar com a nova produção" (ELIAS, 2016, p. 98).

Uma das consequências mais evidentes desse "equívoco" é exemplificada pelo caso das obras interativas que, a partir do momento que são incorporadas à coleção de um museu, não podem mais ser tocadas.

Os museus de arte moderna e contemporânea tornaram-se, assim, vorazes defensores da integridade física da obra, desconsiderando quaisquer fatores que não fossem os ligados à sobrevida do objeto, focando apenas a questão de sua existência material e não de sua imaterial. Dessa forma, transformaram-se (ou sempre foram) em espaços similares aos museus de arte tradicional.

Sendo assim, pode-se considerar que a musealização, somada ao colecionismo indiscriminado, traduz-se em equívocos vários, dentre os quais se podem mencionar aqueles relacionados com a desconsideração da correta interpretação da obra. Problemática visível quando se trata das instalações, não pelo caráter temporário da concretização artística, mas pelas partes que permanecem ou são doadas depois de terminada a exposição e que, em muitos casos, entram para as coleções e são catalogadas ou expostas como obras únicas, totalmente descontextualizadas. (ELIAS, 2016, p. 99)

Em outro ponto, Elias se aproxima de Wharton ao afirmar a importância da documentação museológica considerando que ela passou a ser uma parte fundamental na conservação dos acervos de arte contemporânea:

Diferente das obras tradicionais e convencionalmente construídas, onde as respostas para o tratamento estão, quase sempre, na correta avaliação histórica e estética do objeto, nas obras não tradicionais, essas informações não são evidentes e nem sempre estão apenas na correta avaliação desses fatores. A potencialização conjunta dessas informações, por parte da documentação, conservação-restauração, curadoria e museografia é que propiciará as diretrizes para a intervenção, guarda, manuseio e exposição. Neste modelo gerencial, o centro de confluência e extroversão das informações está no setor de catalogação, local de arquivamento destas.

Para um museu que abriga a arte moderna e contemporânea, se o setor de documentação se ativer às informações materiais e ao percurso histórico do objeto não fornecerá os elementos necessários para auxiliar e direcionar os trabalhos de conservação, restauração e exibição da obra, principalmente daquelas com maior valor de contemporaneidade. Em um modelo orgânico a documentação deve ser vista como elemento intermediário, ter uma participação menos passiva e mais propositiva. As informações que gera e arquiva são basilares para que as áreas atuem com critérios e discernimento, é a ponte para o conhecimento material e imaterial do objeto. Pode-se dizer que a documentação e a conservação-restauração são dois lados de uma mesma moeda, ambas são responsáveis pela conservação da obra, uma conserva a história do objeto através da manutenção de sua documentação e a outra através da manutenção de sua leitura estética ou poética. (ELIAS, 2016, p. 104)

O elenco de questões aqui colocadas não pretendeu estabelecer uma crítica

à musealização, mas sim trazer elementos para se entender como ela se processa 
e, principalmente, observar as especificidades de sua aplicação à arte contemporânea.

É através dos processos de musealização que as instituições museológicas atuam, cumprem suas missões e também se reinventam. Entendemos que, por ser a musealização um processo inerente ao fazer museológico, é importante que ela se dê da maneira mais consciente possível e que seja percebida em toda sua complexidade, tanto pelos profissionais que atuam nos museus, como pelos gestores por eles responsáveis.

Isso se torna especialmente significativo quando tratamos de museus locais, como é o caso da Pinacoteca Municipal de São Caetano do Sul que, diferentemente dos grandes museus, conta com equipes técnicas exíguas e são muito mais sujeitos às mudanças dos ventos nas políticas locais. Esperamos que assim nosso estudo possa trazer uma contribuição efetiva para outras instituições que também compartilham tais características.

Com relação à Coleção dos Salões de Arte Contemporânea de São Caetano do Sul, concluímos que sua musealização foi iniciada com a abertura da Pinacoteca Municipal. É nesse momento que as obras passam a ser documentadas, descritas, fotografadas, adequadamente higienizadas, recebem intervenções de conservação preventiva, são expostas, publicadas em folders, artigos e cartões-postais e guardadas em espaço com controle ambiental, projetado para garantir sua preservação (reserva técnica). Ou seja, as obras recebem o reconhecimento enquanto patrimônio cultural a ser cuidado, comunicado e preservado.

Entendemos que o simples fato de elas terem sido armazenadas, retiradas de circulação, não significou esse reconhecimento ou qualquer garantia de preservação física das mesmas, uma vez que todas, umas mais outras menos, apresentavam algum tipo de dano ou desgaste (sem levar-se em conta as obras “perdidas"). Entendemos também que esse processo de musealização é contínuo e se aprimorará através de estudos que poderão ainda ser desenvolvidos sobre a coleção e os artistas ali representados. Assim, acreditamos que esta dissertação será também uma contribuição para esse processo de musealização, com informações, reflexões e indicações de caminhos que poderão ser usufruídos pelos profissionais e gestores responsáveis por esse acervo. 


\section{CONSIDERAÇÕES FINAIS}

Desde o início do desenvolvimento de nosso projeto de pesquisa, considerávamos quais contribuições poderíamos trazer à Pinacoteca Municipal ao produzirmos a dissertação que aqui estamos apresentando. Essa aspiração nos levou a escolher a coleção de obras dos Salões de Arte de São Caetano do Sul para o estudo por ser um problema ainda não inteiramente abordado pela instituição, pela exiguidade de informações que se tinha sobre a mesma e pelo desafio que representava no campo da pesquisa.

Para cumprir esse objetivo, propusemo-nos a um mergulho na história da cidade, buscando visualizar em quais condições os fatos ocorreram, e mais do que isso, quais as motivações e quais os fatores determinantes levaram à realização dos mesmos. Destacamos também os atores sociais do período e quais papéis foram desempenhados por eles. A construção desse quadro permitiu uma compreensão mais abrangente de todo o processo de constituição da Coleção dos Salões de Arte Contemporânea, bem como seu significado enquanto patrimônio cultural da cidade, o que conferiu ao acervo e à própria Pinacoteca uma dimensão até então desconhecida.

Ao final deste percurso, podemos dizer que a criação dos salões de arte contemporânea e a formação de um acervo de obras de arte para a municipalidade de São Caetano do Sul não foi um ato aleatório, imediatista ou gratuito, e nem isolado; o significado da criação de uma coleção de arte e de um museu de arte contemporânea para a cidade demonstrava o projeto, a visão de uma cidade que queria ser reconhecida como moderna, de vanguarda, projetando-se para o futuro. Ele fez parte de um projeto de cidade pujante, que queria ser, e efetivamente foi, uma cidade mais do que moderna, uma cidade de vanguarda, que abriu espaço para inovações das quais a cultura foi um dos elementos fundamentais, junto aos avanços na Educação, com a construção de escolas em todos os bairros, implantação de ensino técnico, uma escola vocacional e de abertura de unidades de ensino superior. Em suma, um projeto de cidade que se realizava, por mais contraditório que pudesse parecer, dentro de um dos períodos mais duros de uma ditadura cívico-militar e por um governo municipal vinculado ao partido que apoiou tal governo. 
Mas há que se notar que nem todas as ações têm o mesmo sucesso. $O$ museu de arte, pensando na criação dos salões de arte, teve de esperar 35 anos para ser concretizado. Isso trouxe as consequências que já foram apontadas. O "não" processo de musealização fragilizou a preservação do acervo artístico ali reunido, e essa história permaneceu esquecida, restando somente como uma lembrança daqueles que a viveram. Esperamos ter levantado os véus que encobriram esse passado e criado um movimento para romper esse esquecimento.

A preocupação da luta contra o apagamento desse passado foi o que nos levou a trazer a discussão sobre a musealização para este trabalho, por entender que sendo os museus instituições de caráter preservacionista, os processos que eles acionam nas suas atuações são ferramentas imprescindíveis na guarda e ativação dessas memórias.

Nesse sentido, a musealização, que se dá através de todos os processos da cadeia museológica (BRUNO, 1998) é que vai promover a "transformação" das obras de arte ou objetos em patrimônio preservado. E mesmo nas questões apontadas no terceiro capítulo sobre as peculiaridades e os desafios apresentados pela própria natureza da arte contemporânea podem ser superados ou ao menos contornados nos registros e ações a serem tomadas na documentação museológica, nas ações e recomendações da conservação preventiva, nos projetos expositivos e ações educativas onde as obras forem contempladas.

Por isso, mais uma vez sublinhamos a necessidade da realização de estudos desenvolvidos sobre os acervos do ponto de vista mais multidisciplinar possível, a fim de suprir os processos de musealização de informações as mais qualificadas disponíveis. No caso do trabalho aqui desenvolvido, comparando os dados levantados às obras que compõem a Coleção Salões de Arte Contemporânea, foi-nos possível acrescentarmos, e mesmo corrigirmos, informações que constam em suas fichas catalográficas. Foi possível também identificarmos o acervo que "poderia ter sido", ou seja, a relação das obras que se perderam entre o fim dos salões e o resgate das remanescentes pela Fundação PróMemória.

Este estudo não teria sido possível sem a localização dos processos administrativos referentes à realização dos salões de arte de São Caetano. Sem essa documentação primária, não teríamos conseguido informações preciosas, como os regulamentos de todas as edições, as datas e locais onde estes ocorreram, 
e sobre a composição das comissões organizadoras e julgadoras, a relação de artistas e obras inscritos e quais foram os premiados. Recuperamos inclusive os valores pagos nas premiações.

Além disso, cabem aqui algumas conjecturas sobre o período de esquecimento da coleção e das perdas de obras sofridas por ela. Em primeiro lugar, podemos focar as trocas na gestão municipal que levaram a mudanças das políticas culturais, quando o projeto político que lhe deu origem não estava mais em pauta. Essa quebra de continuidade levou à parada dos salões, apesar de sua lei de criação estabelecer a sua realização anual não ter sido revogada. $E$ também ao "esquecimento" da criação do museu de arte.

O fato de as obras colecionadas serem representantes da arte contemporânea foi mais um fator que pode ter dificultado a valorização como um patrimônio artístico, pelo seu distanciamento e dificuldade de reconhecimento e apreciação dessa categoria de arte por parte de um público leigo e afastado das discussões e inovações do campo das artes. No final, toda a inovação que fez da arte contemporânea a representação de um momento particular da história da cidade pode ter sido um dos motivos da precariedade de sua preservação pelo seu não reconhecimento como expressão artística. O museu se mostra mais uma vez uma ferramenta de preservação, ainda mesmo quando ele não existiu e nos desvelando um patrimônio que poderia ter subsistido.

Ao finalizarmos essa dissertação, esperamos que sua contribuição à Pinacoteca Municipal possa potencializar a atuação desta enquanto espaço difusor de arte em sua região, bem como possibilitar um reforço na valorização e ativação da Coleção dos Salões de Arte através e novos projetos expositivos e educativos e que a pesquisa tenha trazido um novo sentido, um novo significado para a coleção na perspectiva do patrimônio cultural de São Caetano do Sul Esperamos, também, que nosso trabalho possa extrapolar os limites do caso em estudo e inspirar instituições análogas a perceberem as contribuições que o estudo das origens de suas coleções poderá trazer na musealização de seus acervos.

Temos consciência de que as pesquisas aqui realizadas geraram resultados que não foram totalmente explorados na produção desta dissertação, e que eles guardam promissoras possibilidades para futuros trabalhos.

Oxalá tenhamos a oportunidade de realizá-los. 


\section{BIBLIOGRAFIA}

\section{ARTIGOS}

8o SALÃO de Arte Contemporânea de São Caetano do Sul - Gravura Catálogo. Artis - Caderno da Fundação das Artes de São Caetano do Sul. São Caetano do Sul, n. 3, p. 55-61, jul. 1975.

ALVIM, Pedro de Andrade, BRANCO, Leonardo de Andrade Gonçalves, ROCHA, Pedro Luis Barreto Vianna. Os Salões de Arte e o Surgimento da Cultura de Massa nos Séculos XVIII e XIX, $16^{\circ}$ Encontro Nacional da Associação Nacional de Pesquisadores de Artes Plásticas Dinâmicas Epistemológicas em Artes Visuais - 24 a 28 de setembro de 2007 - Florianópolis. Disponível em: <http://anpap.org.br/anais/2007/2007/artigos/049.pdf> Acesso em: 10 jul. 2020.

ANDRADE, Milton. Dez anos Salão. Artis - Caderno da Fundação das Artes de São Caetano do Sul. São Caetano do Sul, n. 3, p. 46-53, jul. 1975.

ANTIGO Paço Municipal, 31 anos como símbolo da cidade. Raízes, São Caetano do Sul, n. 21, p. 39-42, jul. 2000.

BATISTA, Felipe Ferreira e CARVALHO, Carlos Eduardo. Carvalho Pinto: Três Aspectos de um destacado político paulista do século XX. Criciúma: XIII Congresso Brasileiro de História Econômica e 14 ${ }^{\text {a }}$ Conferência Internacional de História de Empresas Criciúma, 24, 25 e 26 de setembro de 2019. Disponível em: $<$ http://www.abphe.org.br/arquivos/2019-felipe-ferreira-batista--carlos-eduardocarvalho.pdf> Acesso em: 06 de dez. 2020.

BOSCARDIN, Luiz. Paço de São Bernardo do Campo. Minha Cidade, São Paulo, ano 12, n. 142.03, Vitruvius, maio 2012 Disponível em: https://vitruvius.com.br/revistas/read/minhacidade/12.142/4337, Acesso em: $10 \mathrm{fev}$. 2021.

BRULON, B. Provocando a Museologia: o pensamento geminal de Zbyněk $Z$. Stránský e a Escola de Brno 1. Anais do Museu Paulista: História e Cultura Material, São Paulo, n. 25, p. 403-425, 2017. Disponível em [www.scielo.br]

BRUNO, M. C. O. Museologia e Museus: princípios, problemas e métodos. Lisboa: Universidade Lusófona de Humanidades e Tecnologia, 1996 (Cadernos de Sociomuseologia, $\mathrm{n}^{\circ}$ 9).

BUZZAR, Miguel Antonio, CORDIDO, Maria Tereza Regina Leme de Barros e SIMONI, Lucia Noemia. A arquitetura moderna produzida a partir do plano de ação do governo Carvalho Pinto-Page - (1959/1963). arq.urb, São Paulo, n. 14 p. 1571702 2. sem., $2015 . \quad$ Disponível em $<$ https://revistaarqurb.com.br/arqurb/article/view/257> Acesso em: 06 de dez. 2020

CAMARGO, Mônica Junqueira de. Inventário dos Bens Culturais Relativos ao Plano de Ação do Governo Carvalho Pinto (1959-1963). Revista CPC, São Paulo, n.21 especial, p.164-203, 1. sem. 2016. 
CARAM, André Luís Balsante. O antigo Paço e o Estádio Anacletto Campanella: arquitetura moderna em São Caetano. Raízes, São Caetano do Sul, n. 26, p. 45-51, dez. 2002.

CARVALHO, Cristina Toledo de. A construção de uma cidade nova: a primeira gestão do prefeito Hermógenes Walter Braido (1965-1969). Raízes, São Caetano do Sul, n. 58 p.10-19, dez. 2018.

A criação da Fundação das Artes e a modernidade em São Caetano. Raízes, São Caetano do Sul, n. 56, p. 6-17, dez. 2017.(b)

Acascs: marco da cultura musical em São Caetano. Raízes, São Caetano do Sul, n. 50, p. 6-14, dez. 2014.

O desenvolvimento das artes plásticas no município (1962-1967). Por uma proposta de abordagem histórica do tema. Raízes, São Caetano do Sul, n. 51, p. 6-15, jul. 2015.

Trajetória do Teatro Amador em São Caetano do Sul. Raízes, São Caetano do Sul, n. 32, p. 5-13, dez. 2005.

COELHO, Aguinaldo Caiado de Castro Aquino; MENDONÇA, Míriam Costa Manso M. Realização de salões de arte na década de 1970. Disponível em: $<$ https://files.cercomp.ufg.br/weby/up/778/o/2013-036-

eixo1 Aguinaldo Caiado Coelho.pdf> Acesso em: 10 jul. 2020.

COUTO, Maria de Fátima Morethy. Pensar a Vanguarda em Campinas. Disponível em: <https://periodicos.ufms.br/index.php/cadec/article/view/3534> Acesso em: 05 ago. 2019.

FIORAVANTE, Celso. O marchand, o artista e o mercado. In: Arco das Rosas, o Marchand como curador. Catálogo da mostra, março 2001. Disponível em: $<$ http://www.forumpermanente.org/event pres/exposicoes/arte-contemporaneo-

arco/artigos-relacionados/o-marchand-o-artista-e-o-mercado>. Acesso em: 08 de Jun. 2019.

FUNDAÇÃO das Artes comemora jubileu e confirma espaço no contexto cultural. Raízes, São Caetano do Sul, n. 10, p. 49-52, jan. 1994.

GABRIEL, Raquel Machado Marques. Três Poderes: a arquitetura cívica paulista, 1950-1970. X Seminário DOCOMOMO Brasil Arquitetura Moderna e Internacional: conexões brutalistas 1955-75. Curitiba, 15-18 out. 2013. Disponível em: <http://docomomo.org.br > 2016/08 > OBR 29> Acesso em: 06 dez. 2020.

GARBELOTTO, Oscar. O. A música superando obstáculos. Raízes, São Caetano do Sul, n. 50 p. 15-22, dez. 2014.

Os primórdios do teatro na cidade. . Raízes, São Caetano do Sul, n. 32 p. 14-23, dez. 2005.

GONÇALVES, Aguinaldo. Estudo para subsidiar a proposta de Tombamento do Centro Cívico de Santo André. CONSELHO Municipal de defesa do Patrimônio 
Histórico, Artístico, Arquitetônico-Urbanístico e Paisagístico de Santo André (COMDEPHAAPASA), 2016.

IAFRATE, Monica e TESSARINI, João Alberto. Dez anos com arte: a trajetória da Pinacoteca Municipal. Raízes, São Caetano do Sul, n. 45, p. 75-80, jul. 2012

JACOBINE, Jorge Henrique Scopel. Paço Municipal de São Bernardo do Campo. Centro De Memória De São Bernardo Do Campo, Publicado no Facebook da Secretaria de Cultura e Juventude de SBC, em 03 set. 2018 (VOCÊ SABIA).

KLEEB, Suzana. Manifestações culturais em Santo André: alguns apontamentos sobre o século XX. Santo André: Museu de Santo André Dr. Octaviano Armando Gaiarsa (publicação interna), 2011

LUZ, Ângela Ancona da. Salões Oficiais de Arte no Brasil - um tema em questão. Revista do Programa de Pós-Graduação em Artes Visuais - EBA - UFRJ, p. 5964, 2006. Disponível em: <https://www.ppgav.eba.ufri.br/wpcontent/uploads/2012/01/ae13 angela ancora.pdf> Acesso em: 05 ago 2019.

MEDICI, Ademir. Quarenta anos de política, na análise de Walter Braido. Raízes, São Caetano do Sul, n. 11, p. 4-10, jul. 1994.

MILTON Andrade: uma vida ligada ao desenvolvimento cultural. (Depoimento colhido em 06 de maio de 1995 no evento Vamos falar de São Caetano). Raízes, São Caetano do Sul, n. 21, p. 69-74, jul. 2000.

MORAES, João Carlos de. A formação de São Caetano no contexto da região metropolitana de São Paulo. Raízes, São Caetano do Sul, n. 20, p. 27-34, dez. 1999.

Crescimento demográfico e adensamento acelerado (o caso de São Caetano). Raízes, São Caetano do Sul, n. 12, p. 56-57, jan. 1995.

Formação urbana e espaço habitável em São Caetano do Sul. Raízes, São Caetano do Sul, n. 8, p. 47-49, dez. 1992.

MUSEUM of Modern Art. MUSEUM Statement. Disponível em: <https://www.moma.org/about/who-we-are/moma> Acesso em 17 jun., 2019.

NASCIMENTO, Elisa de Noronha. A musealização da arte contemporânea como um processo discursivo e reflexivo de reinvenção do museu. MIDAS Museus e Estudos Interdisciplinares, v. 3, n. 2014, p 2-13, 2014.

REZENDE, Maria Beatriz, Grieco, Bettina, Teixeira, Luciano, Thompson, Analucia. Fundação Nacional Pró-Memória 1979-1990. Disponível em: $<$ http://portal.iphan.gov.br/dicionarioPatrimonioCultural/detalhes/53/fundacaonacional-pro-memoria-19791990\#: :text=A\%20partir\%20dessas\%20fus\%C3\%B5es\%20o,bra\%C3\%A70\%20exe cutivo\%20da\%20nova\%20Secretaria> Acesso em: 27 jun. 2020.

SILVA, José Armando Pereira da. Teatro local centralizava atividades culturais nos anos 60. Raízes n 21 p. $64-65$ jul 2000 a 
VERONEZI, Henry Conjuntos musicais contribuíram muito para o desenvolvimento artístico da cidade. Raízes no 17 p. 19-24 jul. 1998 a

Raízes no18 p. 9-12 dez. 1998 b

. Primeiras entidades de socorro de São Caetano.

XAVIER, Sonia Maria Franco. Editorial. Raízes n 51, p. 3 jul. 2015.

\section{DEPOIMENTOS}

GARBELOTTO, Oscar: depoimento [maio 2018]. Entrevistadoras: Cristina Toledo de Carvalho e Monica lafrate. São Caetano do Sul, 2018.

SILVA, José Armando Pereira da: depoimento [fev. 2019]. Entrevistadora: Monica lafrate, São Paulo, 2019.

SACRAMENTO, Enock: depoimento [jul. 2020]. Entrevista concedida a autora. Santo André, 2020.

JOVANOVIC, Aleksandar: depoimento [jul. 2020]. Entrevista concedida a autora. Santo André, 2020.

\section{DOCUMENTOS}

CONGRESSO NACIONAL. Lei n 6.757, que autoriza o Poder Executivo a instituir a Fundação Nacional Pró-Memória e dá outras providências, 17 de dezembro de 1979.

COMISSÃO instituída pela Portaria nำ11.395 de 02 de março de 1989 para estudar destinação histórica da área denominada "Buracão da Cerâmica". Projeto para Estabelecimento de Novas Diretrizes e Metas ao Patrimônio Histórico de São Caetano do Sul. São Caetano do Sul, 16 de maio de 1989.

GARBELOTTO, Oscar. Estudo para implantação de novos estabelecimentos de ensino em São Caetano do Sul, realizado pelo diretor do Departamento de Educação e Cultura, 1967.

PREFEITURA MUNICIPAL DE BLUMENAU. Lei n¹835/72, que cria a Fundação Casa Dr. Blumenau, 07 de abril de 1972.

PREFEITURA MUNICIPAL DE SÃO CAETANO DO SUL. Processo n`11325/66. Comissão de Artes Plásticas solicita seja encaminhado ao Legislativo um projeto para criação do salão de artes plásticas contemporânea de São Caetano do Sul, 04 nov. 1966. 
Lei no 1.560 (Processo no. 11.325/66, que cria o Salão de Arte contemporânea). São Caetano do Sul, 27 de abril de 1967a.

- Tese da Delegação Brasileira; Planejamento Municipal de Educação: uma experiência com resultados propositivos relativos ao planejamento de educação no âmbito Municipal. Contribuição da Prefeitura Municipal de São Caetano do Sul, São Paulo, Brasil à Conferência Internacional de Planejamento Governamental de Bankok, fev. 1967b.

. Dois anos de trabalho e tranquilidade, São Caetano do Sul, 1967c

. Decreto no 2.895 (Processo no. 11.325/66, que regulamenta as atividades do Salão de Arte Contemporânea e dá outras providências). São Caetano do Sul, 09 de junho de 1967d.

. Processo no 6472/68. Seção de Cultura encaminha cópia da Lei no 1.560 de 27/04/67 e do Decreto 2.895 de 09/06/67 que criam o Salão de Arte Contemporânea de São Caetano do Sul, solicita providências para os trabalhos para este ano, 08 maio 1968a

São Caetano do Sul planeja seu desenvolvimento (Primeira gestão de Hermógenes Walter Braido). São Caetano do Sul, 1968b

Cidade Nova (Primeira gestão de Hermógenes Walter Braido). São Caetano do Sul, 1969.

Processo no 2.586/74. Departamento de Educação e Cultura, Comissão Executiva do VII Salão de Arte Contemporânea, 05 abr. 1974.

. Processo no 2781/76. Departamento de Educação e Cultura, Salão de Arte Contemporânea 1976, 12 abr. 1976.

Lei no 2.325 (Processo no. 11.325/66, que dispõe sobre o funcionamento do Salão de Arte Contemporânea). São Caetano do Sul, 03 de junho de 1976.

. Decreto no 4.221 (Processo n․ 11.325/66, que regulamenta as atividades da Mostra de Arte Contemporânea e dá outras providências). São Caetano do Sul, 29 de junho de 1976.

Processo n 3990/79. Departamento de Educação e Cultura, Salão de Arte Contemporânea, 10 maio 1979.

Processo no 3698/88. Departamento de Educação e Cultura, Salão de Arte Contemporânea 1988, 23 maio. 1988.

- Lei no 3.147 (Processo no. 1.157/89, que autoriza ao Executivo Municipal a instituir a Fundação Pró-Memória de São Caetano do Sul). São Caetano do Sul, 12 de junho de 1991.

Decreto no 4.221 (Processo no. 11.325/66, que transfere para a Fundação Pró-Memória as obras adquiridas em "Prêmio Aquisição", de 
conformidade com a Lei $\mathrm{n}^{\circ} 1.560$ de 27/04/67, nos concursos denominados "Salões de Arte Contemporânea e dá outras providências). São Caetano do Sul, 08 de março de 1993.

\section{LIVROS E CAPÍTULOS DE LIVROS}

100 ANOS da Pinacoteca: a formação de um acervo. São Paulo: FIESP/SESI/SENAI/IRS, 2005. Catálogo da exposição realizada no Centro Cultura FIESP, Galeria de Arte do SESI, em São Paulo, de 16 ago.-16 out. 2005

ALTSHULER, Bruce. Colecionando Arte Contemporânea em Museus e Relações entre Forma e Conteúdo de Exposições. In: GONÇALVES, Lisbeth Rebollo (ORG.). Sobre Museus: conferências. São Paulo: MAC USP, 2010.

ALTSHULER, Bruce. Collecting the new: a historical introduction. Collecting the new: museums and contemporary art. Princeton: N.J. Princeton University Press, p. 1-13, 2005.

AMARAL, Aracy A.. Arte para quê? A preocupação social na arte brasileira 19301970. São Paulo: Nobel, 1984

AMARAL, Aracy A. Cêntricos e ex-cêntricos: que centro? Onde está o centro? In: Textos do Trópico de Capricórnio: Artigos e ensaios (1980-2005). São Paulo: Ed. 34, v. 2 p. 222-224, 2006a.

AMARAL, Aracy A. Os salões beneficiam a formação dos acervos dos museus? In: Textos do Trópico de Capricórnio: Artigos e ensaios (1980-2005). São Paulo: Ed. 34, v. 2 p. 222-224, 2006b.

ASSOCIAÇÃO Cultural de Amigos do Museu Casa de Portinari. Documentação e Conservação de Acervos Museológicos: Diretrizes. Brodowski: Associação Cultural de Amigos do Museu Casa de Portinari/ São Paulo: Secretaria de estado da Cultura de São Paulo, 2010.

BERTONHA, João Fábio. O fascismo e os imigrantes italianos no Brasil. Porto Alegre: EDIPUCRS, 2017.

BRUNO, M. C. O. (coord.). Waldisa Rússio Camargo Guarnieri: textos e contextos de uma trajetória profissional. São Paulo: Pinacoteca do Estado, 2010. v. 1

BRUNO, M. C. O. Museologia e Turismo: caminhos para educação patrimonial. São Paulo: CEETESP, 1998.

BRUNO, M. C. O. Museologia e Turismo: caminhos para educação patrimonial. São Paulo: CEETESP, 1998.

CALADO, M.; SILVA, J. H. Pais da. Dicionário de Termos de Arte e Arquitetura. Lisboa: Editorial Presença, 2005 
CAUQUELIN, Anne. Arte Contemporânea; Uma Introdução. São Paulo: Martins, 2005

CRIMP, Douglas. Sobre as ruínas do museu. São Paulo: Martins Fontes, 2005.

DESVALLÉES, A.; MAIRESSE, F. Conceitos-chave de museologia. São Paulo: Comitê Brasileiro do Conselho Internacional de Museus: Pinacoteca do Estado de São Paulo: Secretaria de Estado da Cultura, 2013.

DICIONÁRIO Brasileiro de Terminologia Arquivística. Rio de Janeiro: Arquivo Nacional, 2005.

DURHAN, Eunice Ribeiro. Texto II. In: ARANTES, Antônio Augusto (org.). Produzindo o Passado: estratégias de construção do Patrimônio Cultural. São Paulo: Brasiliense, 1984. P. 23-58.

ELIAS, Isis Baldini. Valor da contemporaneidade: conservação e restauro de obras de arte. São Paulo: EDUC: FAPESP, 2016.

FAUSTO, Boris. História Concisa do Brasil. São Paulo: Editora da Universidade de São Paulo, 2006.

FEIGENBAUM, Gail; REIST, Inge (Org.) Provenance: An Alternate History of Art. Los Angeles: The Getty Research Institute, 2012.

FREIRE, Cristina (org.). Walter Zanini: escrituras críticas. São Paulo: Annablume: MAC USP, 2013.

HUYSSEN, Andreas. Passados presentes: mídia, política e amnésia. In:

Seduzidos pela Memória. Rio de Janeiro: Aeroplano, p. 9-40, 2004

LANGENBUCH, Juergen Richard. A Estruturação da Grande São Paulo. Rio de Janeiro: Instituto Brasileiro de Geografia, 1971.

LODUCA, Wilson. São Caetano: de várzeas alagadiças a Príncipe dos Municípios. São Paulo: HUCITEC; São Caetano do Sul: Prefeitura Municipal de São Caetano do Sul, 1999.

LOUREIRO, M.L.N.M. Reflexões sobre Musealização: processo informacional e estratégia de preservação. In: Maringelli, Isabel Ayres (org.). III Seminário Serviços de Informação em Museus: colecionar e significar: documentação de acervos e seus desafios. São Paulo: Pinacoteca de São Paulo, p. 91-103, 2016.

LUZ, Ângela A. Uma breve história dos Salões de Arte: da Europa ao Brasil. Rio de Janeiro, Caligrama, 2005.

MAGALHÃES, Ana Gonçalves. Estudos de proveniência e colecionismo: Apontamentos para uma análise da formação de acervos de arte no Brasil. In: Maringelli, Isabel Ayres (org.). III Seminário Serviços de Informação em Museus: colecionar e significar: documentação de acervos e seus desafios. São Paulo: Pinacoteca de São Paulo, p. 37-47, 2016. 
MALRAUX, André. O Museu Imaginário. Lisboa: Edições 70, 2011.

MARTINS, José de Souza. A aparição do demônio na fábrica: origens socais do Eu dividido no subúrbio operário. São Paulo: Ed. 34, 2008.

MARTINS, José de Souza. Subúrbio. Vida cotidiana e história no subúrbio da cidade de São Paulo: São Caetano, do fim do Império ao fim da República Velha. São Paulo: HUCITEC, 1992.

MEDICl, Ademir. GIPEM e o Resgate da Memória numa Região Operária. In: Revista do Instituto de Estudos Brasileiros, São Paulo, n. 34, p. 45-50, 1992.

MEDICl, Ademir. Migração e urbanização: a presença de São Caetano na região do ABC. São Paulo: HUCITEC; São Caetano do Sul: Prefeitura Municipal de São Caetano do Sul, 1993.

MILLET, Catherine. Arte Contemporânea. Lisboa: Instituto Piaget, 1997.

OLIVEIRA, Emerson Dionísio G. de. Museus de fora: a visibilidade dos acervos de arte contemporânea no Brasil. Porto Alegre: Zouk, 2010.

PEDROSA, Mario. Dos murais de Portinari aos espaços d Brasília. São Paulo: Editora Perspectiva, 1981.

POMIAN, K. Coleção. In: Enciclopédia Einaudi volume 1. [s.l.] Imprensa Nacional; Casa da Moeda, p. 51-86, 1984.

POULOT, Dominique. Museu e Museologia. Belo Horizonte: Autêntica Editora, 2013.

REIS, Manuel (org.). A Crítica de Arte no ABC: Seleção de matérias publicadas no jornal Diário do Grande ABC. São Paulo: Terceira Margem, 2009.

RÚSSIO, W. C. G Conceito de Cultura e sua inter-relação com o patrimônio cultural e a preservação. In: BRUNO. M.C.O.; ARAÚJO, M.M.; COUTINHO, M.I.L. Waldisa Rússio Camargo Guarnieri: textos e contextos de uma trajetória profissional. São Paulo: Pinacoteca do Estado: Secretaria de Estado da Cultura: Comitê Brasileiro do Conselho Internacional de Museus, p. 203-210, 2010b.

RÚSSIO, W. C. G Museu para quê? (A necessidade da Arte). In: BRUNO. M.C.O.; ARAÚJO, M.M.; COUTINHO, M.I.L. Waldisa Rússio Camargo Guarnieri: textos e contextos de uma trajetória profissional. São Paulo: Pinacoteca do Estado: Secretaria de lestado da Cultura: Comitê Brasileiro do Conselho Internacional de Museus, p. 69-77, 2010c.

RÚSSIO, W. C. G. A Interdisciplinaridade em Museologia. In: BRUNO. M.C.O.; ARAÚJO, M.M.; COUTINHO, M.I.L. Waldisa Rússio Camargo Guarnieri: textos e contextos de uma trajetória profissional. São Paulo: Pinacoteca do Estado: Secretaria de lestado da Cultura: Comitê Brasileiro do Conselho Internacional de Museus, p. 123-126, 2010a 
SANTOS, Wanderley dos. Antecedentes Históricos do ABC Paulista: 1550-1892. São Bernardo do Campo: Prefeitura Municipal de São Bernardo do Campo, 1992.

SILVA, José Armando Pereira da. Escola de Teatro da Fundação das Artes de São Caetano do Sul (1969-1982). Santo André: Alpharrabio Edições, 2011.

SILVA, José Armando Pereira da. Província e Vanguarda: apontamentos e memória de influências culturais, 1954-1964. Santo André: Funda de Cultura do Município de Santo André, 2000 b.

TAUNAY, Affonso de E. João Ramalho e Santo André da Borda do Campo. São Paulo: Comissão Executiva dos Festejos do Quarto Centenário da fundação de Santo André, 1968.

VILLA, Bona De, e Outros. A problemática da localização industrial na Grande São Paulo. São Paulo: Departamento de Publicações FAUUSP, 1975.

WHARTON, Glenn. The Challenges of Conserving Contemporary Art. In: ALTSHULER, Bruce. Collecting the new: museums and contemporary art. Princeton: N.J. Princeton University Press, p. 163-178, 2005

\section{MATÉRIAS EM JORNAIS}

A ARTE e o Natal. O Acascs Jornal, São Caetano do Sul, ano II, n. 21 e 22, p. 18, nov. e dez. 1964.

ARTES Plásticas. Arte Contemporânea/76 São Caetano reformula seu salão anual. Diário do Grande ABC, 02 jun. 1976.

A.C.A.S.C.S um nome, uma história. O Acascs Jornal, São Caetano do Sul, ano I, n. 1, 1aㅡ página, mar. 1963.

AGENOR e Sinval expõem em S.C.S. Jornal de São Caetano, São Caetano do Sul, ano XVII, n. 933, p. 4, 29 set. 1962.

ASSOCIAÇÃO Cultural e Artística de São Caetano do Sul comemora aniversário. Jornal de São Caetano, São Caetano do Sul, ano XVII, n. 949, 19 jan. 1963.

CIDADE nova. Por que? Jornal de São Caetano, São Caetano do Sul, ano XXII, n. 1.184, p. 2, Suplemento Especial Comemorativo aos 90 anos de São Caetano do Sul e aos 21 anos do Jornal de São Caetano, 30 jul. 1967.

CONFERÊNCIA. O ACASCS Jornal, São Caetano do Sul, n. 20, 1964, p.3

EXPOSIÇÃO de arte do Centro Acadêmico iniciou os festejos do 85a aniversário. Jornal de São Caetano, São Caetano do Sul, ano XVII, n. 924, p. 3, $1^{\circ}$ Caderno, 28 jul. 1962.

KLEIN, Paulo. Aberta ao público com a não-arte de Granato. Diário do Grande ABC, Santo André, Caderno A p. 16, 01 ago. 1976. 
PINTURA projetará São Caetano em todo o Estado. Jornal de São Caetano, São Caetano do Sul, ano XVII, n. 971, 1aa página, 22 jun. 1963.

POR QUE em S. Caetano do Sul escola não é problema. Jornal de São Caetano, São Caetano do Sul, ano XXII, edição extra, p. 2, 3 ago. 1967.

SALÃO de Arte Contemporânea será sucesso. Jornal de São Caetano, São Caetano do Sul, ano XXI, n. 1.182, p. 4, 15 jul. 1967.

SINVAL (entrevista). O Acascs Jornal, São Caetano do Sul, ano II, n. 16, 1a página, jun. 1964.

SUCURSAL ABC, Novos não entram no Salão de São Caetano. O Estado de São Paulo, p.9, 1976.

\section{TESES, DISSERTAÇÕES E MONOGRAFIAS}

BOTTALLO, Marilúcia. Arte Moderna e Contemporânea em São Paulo, o museu como intermediário. Dissertação (Mestrado) - Escola de Comunicações e Artes, Universidade de São Paulo. São Paulo. 183f. 2001.

CARVALHO, Cristina Toledo de. Do Subúrbio à Modernidade: a construção e difusão de um ideal de município em São Caetano do Sul (1948-1991). Projeto de pesquisa apresentado ao Programa de Estudos Pós-Graduados em História da Pontifícia Universidade Católica de São Paulo, como exigência parcial para participação no processo seletivo do Doutorado. São Paulo, 2017a.

KASSEB, Giselle. O processo de industrialização e sua influência no desenvolvimento urbano; o caso de São Bernardo do Campo. Monografia de Economia Urbana e Regional do Curso de Pós-Graduação da Faculdade de Arquitetura e Urbanismo da Universidade Presbiteriana Mackenzie. São Paulo, $1990 ?$.

KUVASNEY, Eliane; SEABRA, Odette Carvalho de Lima. "Separar para reinar": desmembramentos na gênese da metrópole paulistana. Dissertação apresentada para obtenção do título de Mestre em Geografia Humana, Faculdade de Filosofia, Letras e Ciências Humanas, Departamento de Geografia, Universidade de São Paulo, São Paulo, 1996.

NASCIMENTO, Elisa de Noronha. Discursos e Reflexividade: um estudo sobre a Musealização da Arte Contemporânea. Tese (Doutorado em Museologia). Faculdade de Letras, Universidade do Porto, 352f. 2013.

NEGRISOLLI, Douglas. As Urgências para os Salões Municipais de Arte Contemporânea no ABC Paulista. Universidade Presbiteriana Mackenzie, São Paulo, 2016. Tese de doutoramento programa de pós-graduação em Educação, Arte e História da Cultura.124f 
NEGRISOLLI, Douglas. Os Salões de Arte Contemporânea de santo André: 1968 a 1985. Universidade Presbiteriana Mackenzie, São Paulo, 2016. Dissertação de mestrado programa de pós-graduação em Educação, Arte e História da Cultura.185f

SILVA, José Armando Pereira da.. Thomaz Perina e a Vanguarda em Campinas. Dissertação (Mestrado), Programa de Pós-Graduação Interunidades em Estética e História da Arte, Universidade de São Paulo, 145 f 2005

VAZ, I. Sobre a Musealidade. Dissertação apresentada ao Programa de PósGraduação Interunidades em Museologia (Mestre em Museologia), Universidade de São Paulo, São Paulo, 2017.

ZAGO, Renata Cristina de Oliveira Maia. Os Salões de Arte Contemporânea de Campinas. Dissertação Mestre em Artes Instituto de Artes da Universidade Estadual de Campinas Campinas 2007 160f

\section{SITES}

12ํㅗㅇ São Paulista de Arte Moderna. In: ENCICLOPÉDIA Itaú Cultural de Arte e Cultura Brasileiras. São Paulo: Itaú Cultural, 2019. Disponível em: <http://enciclopedia.itaucultural.org.br/evento82646/12o-salao-paulista-de-artemoderna>. Acesso em: 29 jun. 2019.

ALBERTO Aliberti. In: ENCICLOPÉDIA Itaú Cultural de Arte e Cultura Brasileiras. São Paulo: Itaú Cultural, 2019. Disponível em: <http://enciclopedia.itaucultural.org.br/pessoa21360/alberto-aliberti>. Acesso em: 29 de Jun. 2019.

CONVENÇÃO das Nações Unidas sobre o direito das pessoas com deficiência. PCD Mais. Disponível em: <https://pcdmais.com.br/pcd-pne-afinal-que-termo-usar-parapessoas-com-deficiencia/> Acesso em 23 de jun. de 2021.

FUNDAÇÃO Pró-Memória de São Caetano do Sul. Disponível em: <http://www.fpm.org.br/Sobre/Index/1> Acesso em 26 jun. 2020.

NOSSA História. In: Associação Paulista de Belas Artes, 2019. Disponível em: <http://www.apba.com.br/index.php/nossa-historia>. Acesso em: 08 de Jun. 2019.

PINACOTECA Municipal. Disponível em <http://www.fpm.org.br/Sobre/Pinacoteca/1 >. Acesso em 16 jun. 2020 


\section{ANEXOS}

ANEXO A Lei no 1.560, que cria o Salão de Arte contemporânea de 27 abr. 1967

ANEXO B Lista das obras de 1994

ANEXO C Coleção Salões de Arte Contemporânea

ANEXO D Ficha Técnica Salões de Arte Contemporânea

ANEXO E Participantes das Comissões de seleção e Julgamento / Premiação

ANEXO F Artistas participantes dos Salões de Arte Contemporânea

ANEXO G Obras Perdidas

ANEXO H Obras não premiadas que constam na Coleção dos Salões 
ANEXO A

Lei no 1.560, que cria o Salão de Arte contemporânea de 27 abr. 1967

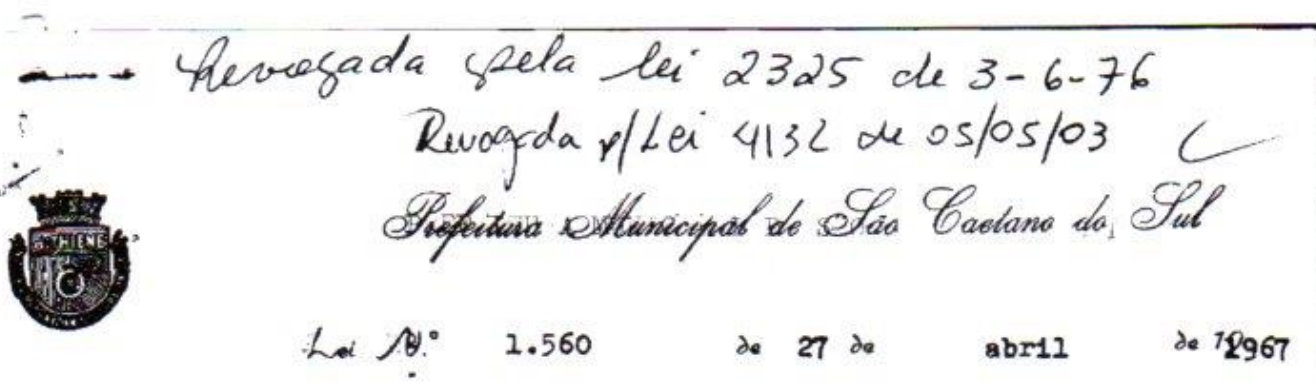

Proc. 11.325/66 "Cr1a O Selão de Arte Contemporânea".

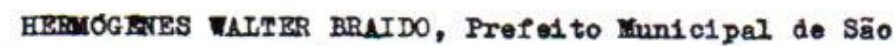
Caetano do Sul, usando das atribulçōes que lhe são confer1das por Iei,

Paz asber que a Cāmara, sessão realizada no d1a 20 do corrente mês, decretou e êle promulga a seguinte Le1:

Artigo ${ }^{2}$ - Plo criado o Salão de Arte Contemporânea no Muntel pło, que será promovido pelo Departamento de Bducação - Cultura, destinado a reunir e premiar traba lhos representativos de artes-plátlcas, a realizar -qe anvalmente.

Parágrafo Un1co- 0 certame compreenderá as seguintes secçōes:

I - pintura;

II - escultura;

III - arté-grál1ca; •

IV - arte decorativa

Artigo 2s - Os prêmes a primelro e segundo colocado, de ca da Secção, ae denominarão MFReuro PRBPBITURA WUNICI PAL DE SXO CLEMAFO DO SUL" eonetarão de medalhas - importancias, ext dinheiro, a seren fixadas por de oreto do Prefel to Mnicipal.

Parágrafo Onflco- Os trabalhog preslados pasaräo a fazer partedo acerro mantcipal.

Artigo $3^{2}$ - As despesas decorrentes da presente Lei, serão co bertas neste exercic1o, pelas verbas próprlas do or gamen to Figente.

Parágrafo Untco- Para os exercicios posteriores, conatarão dos orçamentos, verbas próprias. 
ANEXO B

Lista das obras de 1994

OBRAS DA EXPOSICÃO

I SALÃO 1967

= MASSUO NAKAKUMO " DESENHO № 16" RESTAURAR;

= HERMELINDO FIAMIGHI, ( 3 obras) RESTAURAR;

= NIOBE XANDÓ RESTAURAR:

" JOÄO SUZUKI " DESENHO" RESTAURAR;

\section{SALÃ̃O 1968}

IJBIRAJARA MARTINS ( 3 obras) OK;

ERNESTINA KARMAN " ESQUADRILHA" RESTAURAR;

JOAO PARISI FIIHO " CINEMA I, II, III " RESTAURAR;

HIMBERTO AUGUSTO MIRANDA ESPINDOLA " NA ESPERA DO DINHEIRO DO BOI"OK

- MANOEL DE MATOS VINAGRE, BANDARRA "GENESIS" RESTAURAR;

= ANTONIO HENRIQUE AMARAL "INCOMUNICACÃO" RESTAURAR;

\section{SALÄO 1969}

ALUISIO D. DOS SANTOS, ( 3 OBRAS) , DUAS CARECEM RESTAURAR;

LUIZ NADE PICCININI "FORMAS EM DECÁDENCIA" OK;

FEGIS M. SILVA ( 3 OBRAS ) "CONSTRUÇÃD , I, II, III" RESTAURAR;

RIBBEN REY (4OBRAS) NÃO PERTENCEM AO PATRIMONNIO DA PREFEITURA;

- SEPP BENDERECK "GLORIA" RESTAURAR;

FRANCISCA CAROLINA DOVAL " CORPOS 5" RESTAURAR;

ALDIR MENDES DE SOUZA"TECNOLOGIA AGRÍCOLA III" REST UURAR;

CLÁUDIO TOZZI" LIGAÇÃO TEIEFÔNICA" OK

PAULO MENIN " ÀS VEZES FALO" OK

= VERA IICE ( OBRA III ) RESTAURAR;

= SERGIUS EDERLYI " TIMEO" PESTAURAR;

IV SALÃO 1970

= ROMILDO PAIVA " O HOMEM E A MÁQUINA I" ( NÃO EXISTE A OBRA);

HANNA H. BRANDT " CAMPOS" ( NÃO EXISTE A OBRA);

VICENTE DE FRANCO FILHO" PSICO III" RESTAURAR;

PAULO CHAVESO " HOMILIA" OK

SONIA VON BRUSKY " SIMBOLIAMO DIÁBOLICO" ( NÃO EXISTE A OBRA)

BETHY WONTEIRO GUIDICE " VIVACE" RESTAURAR;

SINVAL CORPEIA SOARES "PTNTURA NN 60/ PINTURA NN 70" AMBAS OK;

PEDRO TORT " PINTURA 31" RESTAURAR;

EMI MOPE " OBRA I " RESTAURAR;

\section{SALÄO 1971}

ANTONIO LIZARRAGA " TORQUES CRTTÉRTOS A E B " ( 2 OBRAS), NĀO EXISTEM:

HANS SILLMAN GRUDZINKI " N. SENHORA DE TODOS OS PORTOS" OK

ANTONIO CARLOS RODRIGUES, TUNEU " DESENHO I.A " OK 
= STNVAL COREIA SOARES " COESÃO SUPERPOSTA NN 61 " OK

= CLFBER BORETTI MACHADO " FOTOGRAFTA ÓLEO E S/ PAPEL "OK

= ROMÄO BERTONCEL " PAISAGEM II" RESTAURAR;

= MARIA TTEREZA. R. DE GRACA. " COMPOSICXAOO NO ESPAŞO" RESTAURAR;

= CESAR O.A. PELEGRTNO" DESENHO IIJ'1 ( NÃO EXISTE A OBRA);

= VANLA PEREIRA" CLARÖES" OK

= MÁRTO MARCOS TAGININI" TUDO PASSA, TUDO ..." ( NÄO IXISTE A OBRA)

= LUCILTA TLOLDO MEZZOTERO" MENINAS" OK

\section{SALÃO 1974}

= JOÃم \$UZUKI " MAGIA 3" OK

= EMI MORE " CORPO FEMTNWNOII" RESTAURAR;

= LYA AMARAL SOUZA "DESERHO II "RESTAURAR;

$=$ CHARBEL " BLINDADO IV " $O K$

- RONILDO PATVA" PFÓTESE I " OK

$=\mathrm{J}$. RISSTN " BUIMA MEU BOI ${ }^{11}$ OK

= MANFREDO SOUZA NETO " MEMORTAS DE PAISAGENS "OK;

$\zeta=$ ODAIIR MAGAIHÄES "ULTRAPASSANDO O TEMUPO..."

= LUIZ CARLOS TERREAZTOLLI " VIA VEMUUS" OK

= ROSA MARTA CABRAL T. BARRETO " VOLITA DE AREIA" OK

= ROSA MARTA CABRAL TA CERTMONIA SECRETA" ( NÄO EXISTE A. OBRA)

\section{YIIISAIAOO}

= RÖLIDO PATVA " COADICTONAMENTO A , B , C " A E B - RESTALIRAR /C- NÄO E_

OIUTE A CBRA ;

- HANRA BRANDT " FOLHAS SOLTAS II " RESTALEAR;

= ELFTTR " ESHOURO DA BOIADA" RESTAURAR;

= KETICHE KANEKO "EVOLUÇÄD A, B, C" ABRAS RESTAURAR;

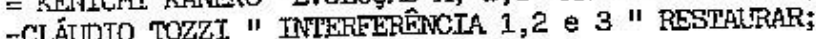

= VÂRLA PEPEIRA "FOE PLAINANDO" OK

= MASSLO NAKAKUEO " A E $\mathrm{B}$ " AMBAS RESTAURAR;

$\lambda=$ ELENIR " FAVELA II "

- ANTONIO VITOR" SÉRTE ECÓLOGICA I E II " AMPAS OK;

= MARÍLTA SABOYA "SEM MIITULO A" OK

= AURESNEDE P. STEEPHAN "VIDA IIT" RESTAUTAR;

= HANS 3 . GRUDZINSKI" PEIXES IIHAS E SOL"/ RESTAUJRAR / IIHAS NO ESPACGOIOK/

: DULLIO GALLI " PAISAGEV UREANA I " PESSRALRAR;

= DUENTR " MANDACARÚ II " (NÄOIEXTSTE A OBRA )

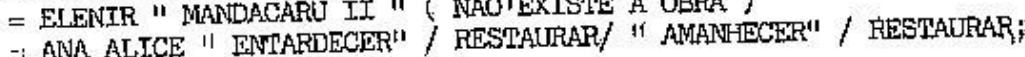

IX SAIÃO 1976

- RIREAS GUERSHNAM " MAN WOMAN" OK / " A TELLETSÃO "OK

EVANDRO CARLOS JARDTM " MADRUGADA" OK

CLÂUTO TOZZE" DISSCCIACẼO DAS CORES" OK

= GREGÓRTO GRUBER I, II, III, IV'10K

= CLÁUDIO RODRIGUES " SEM "ITTULO II " RESTAURAR!

= PALLO RORERTO LEAL " ENIPEYTELA" OK

X SALÃO 1979

= HÉLIO VINCI ( 3 OBRAS): "SEM TITULO" / " LABTRINTO " / RENATO" / OK TO

DAS,

= SERGIO DE MORAIS " CASA DE AMIGO " RESTAURAR;

= SÉRGTO NICULITCHEFE " VIDA " JOK 


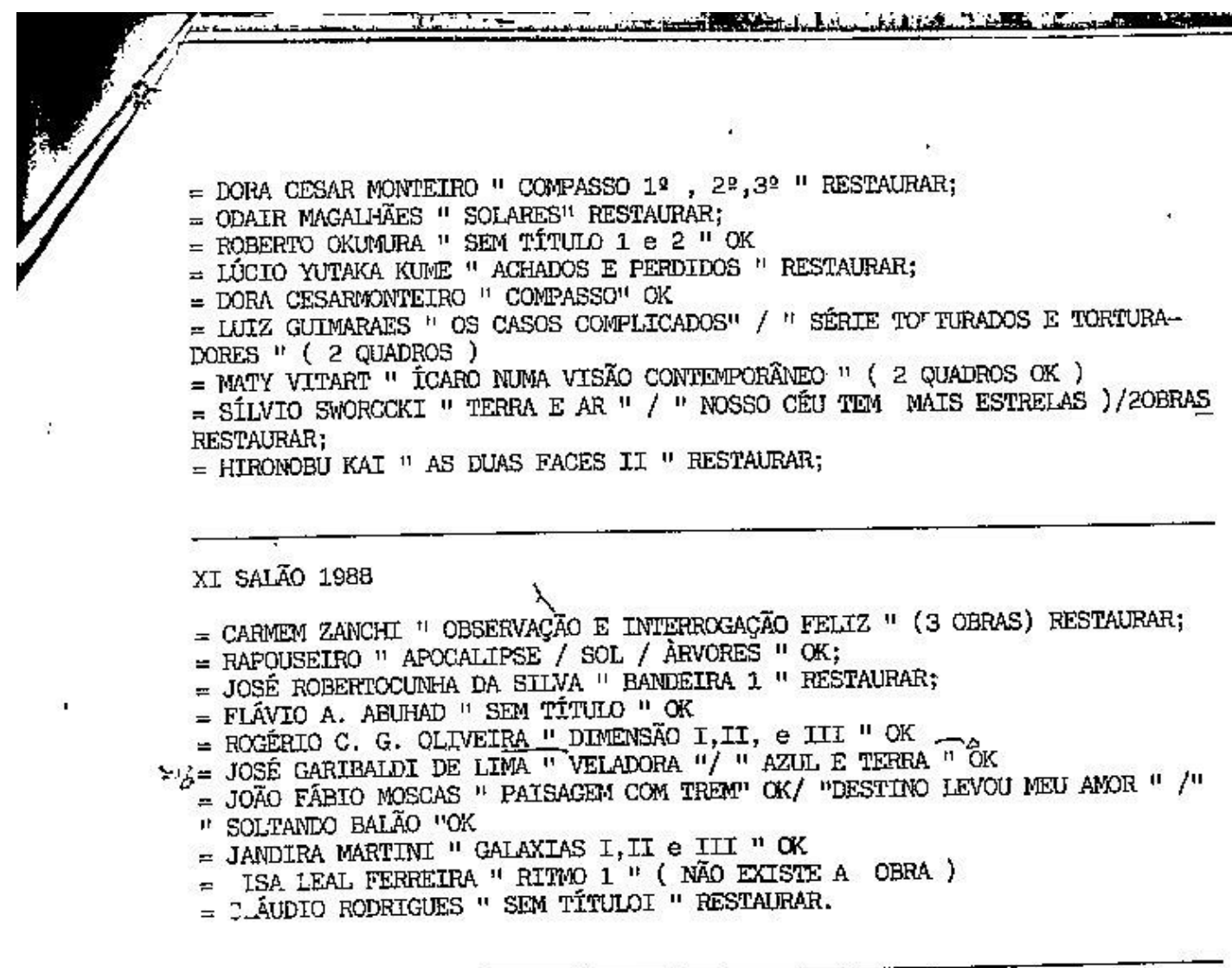

|

= DOI2A CESAR MONTEIRO " COMPASSO $12,20,30$ " RESTAURAR;

DORA CESARPTONTETRO II COMIPASSO" OK

IETZ GUIMIARAES "OS CASOS COMPI TCADOS" / "I SERTE TO TIRADOS F MORTURA-

TMTY VTTART " TCABO NUMA VYSTO CONTOMPORA

RESTAURAR;

HTRONOBU KAI " AS DUAS FACES II " RESTAURATR;

XI SALÃO 1988

DAPUSETRO " APOCATTPSE / SOL / ADVORES " OK:

- JOSE ROBERTOCUNHA DA STLVA " BATDEIPA I " RESTTAURAR

"PATSACER COM TREM" OK/ "DESTTHO LEVOU MEU ANOR "/"

" SOLTANDO BALÃ̂O "OK

" JANDIRA MARTTNT " Gataxis

" ISA LEAL FERRGIES " SEM TÍTULOI " RESTAURAR. 
Coleção Salões de Arte Contemporânea

Fundação Pró-Memória de São Caetano do Sul

Pinacoteca Municipal

Obras dos Salões de Arte Contemporânea

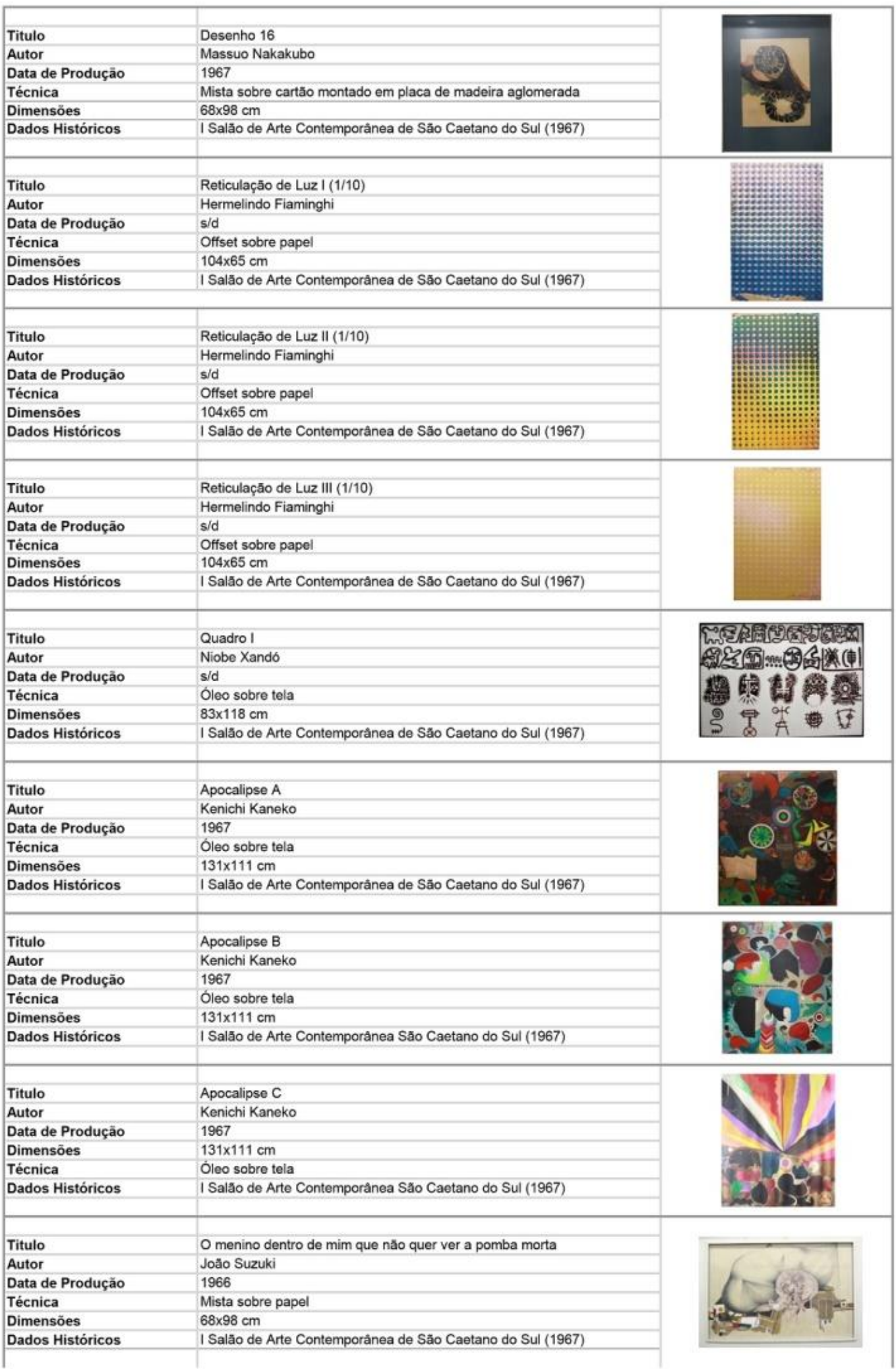


Fundação Pró-Memória de São Caetano do Sul

Pinacoteca Municipal

Obras dos Salōes de Arte Contemporânea

\begin{tabular}{|c|c|c|}
\hline Titulo & Mitologia I & \multirow{6}{*}{$\frac{1}{-0.00}$} \\
\hline Autor & Hissao Shirai & \\
\hline Data de Produçāo & 1967 & \\
\hline Técnica & Óleo sobre tela & \\
\hline Dimensōes & $100 \times 100 \mathrm{~cm}$ & \\
\hline Dados Históricos & I Salão de Arte Contemporânea São Caetano do Sul (1967) & \\
\hline Titulo & Nú & \\
\hline Autor & Algacyr da Rocha Ferreira & \\
\hline Data de Produção & 1967 & \\
\hline Técnica & Mista sobre placa de madeira aglomerada & \\
\hline Dimensōes & $69 \times 48 \mathrm{~cm}$ & \\
\hline Dados Históricos & I Salăo de Arte Contemporânea de Săo Caetano do Sul (1967) & \\
\hline Titulo & A cópula & \\
\hline Data de Produção & 1967 & \\
\hline Técnica & Mista & \\
\hline Dimensöes & $70 \times 60 \mathrm{~cm}$ & \\
\hline Dados Históricos & II Salăo de Arte Contemporánea de Sảo Caetano do Sul (1968) & \\
\hline Titulo & O Vampiro & \\
\hline Autor & Ubirajara Motta Lima Ribeiro & \\
\hline Data de Produção & 1967 & \\
\hline Técnica & Mista & \\
\hline Dimensōes & $70 \times 60 \mathrm{~cm}$ & \\
\hline Dados Históricos & II Salāo de Arte Contemporånea de São Caetano do Sul (1968) & \\
\hline Titulo & O Cinema & \\
\hline Autor & Ubirajara Motta Lima Ribeiro & \\
\hline Data de Produção & 1968 & \\
\hline Técnica & Mista & \\
\hline Dimensōes & $70 \times 60 \mathrm{~cm}$ & \\
\hline Dados Históricos & II Salão de Arte Contemporánea de São Caetano do Sul (1968) & \\
\hline Titulo & Esquadriha & \\
\hline Autor & Ernestina Sanná Karman & \\
\hline Data de Produçāo & 1967 & \\
\hline Técnica & Assemblage & \\
\hline Dimensōes & $108 \times 88 \mathrm{~cm}$ & \\
\hline Dados Históricos & II Salăo de Arte Contemporânea de São Caetano do Sul (1968) & \\
\hline Titulo & Cinema I & \\
\hline Autor & Joāo Parisi Filho & \\
\hline Data de Produçāo & 1967 & \\
\hline Técnica & Óleo sobre placa de madeira aglomerada & \\
\hline Dimensōes & $147 \times 63 \mathrm{~cm}$ & \\
\hline Dados Históricos & II Salāo de Arte Contemporânea de São Caetano do Sul (1968) & \\
\hline Titulo & Cinema II & \\
\hline Autor & Joầo Parisi Filho & \\
\hline Data de Produção & 1968 & \\
\hline Técnica & Óleo sobre placa de madeira aglomerada & \\
\hline Dimensōes & $132 \times 62 \mathrm{~cm}$ & \\
\hline Dados Históricos & II Salão de Arte Contemporânea São Caetano do Sul (1968) & \\
\hline Titulo & Cinema III & \\
\hline Autor & Joăo Parisi Filho & \\
\hline Data de Produção & 1967 & 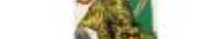 \\
\hline Técnica & Óleo sobre placa de madeira aglomerada & \\
\hline Dimensőes & $147 \times 63 \mathrm{~cm}$ & \\
\hline Dados Históricos & II Salão de Arte Contemporånea de São Caetano do Sul (1968) & \\
\hline
\end{tabular}


Fundação Pró-Memória de São Caetano do Sul Pinacoteca Municipal

Obras dos Salōes de Arte Contemporânea

\begin{tabular}{|c|c|}
\hline Titulo & $\mathrm{Na}$ espera do dinheiro do boi \\
\hline Autor & Humberto Espindola \\
\hline Data de Produçăo & $s / d$ \\
\hline Técnica & Mista \\
\hline Dimensões & $89 \times 150 \mathrm{~cm}$ \\
\hline Dados Históricos & II Salāo de Arte Contemporănea de São Caetano do Sul (1968) \\
\hline Titulo & Gēnesis \\
\hline Autor & Manuel Bandarra \\
\hline Data de Produçāo & 1968 \\
\hline Técnica & Assemblagem \\
\hline Dimensōes & $130 \times 150 \times 10 \mathrm{~cm}$ \\
\hline Dados Históricos & II Salāo de Arte Contemporânea de São Caetano do Sul (1968) \\
\hline Titulo & Cavalo Branco \\
\hline Autor & Techa Ivanova \\
\hline Data de Produção & 1967 \\
\hline Técnica & Óleo sobre tela \\
\hline Dimensōes & $51 \times 73 \mathrm{~cm}$ \\
\hline Dados Históricos & II Salāo de Arte Contemporânea de São Caetano do Sul (1968) \\
\hline Titulo & Incomunicação \\
\hline Autor & Antonio Henrique Amaral \\
\hline Data de Produçāo & 1968 \\
\hline Técnica & Acrilica sobre tela \\
\hline Dimensōes & $130 \times 160 \mathrm{~cm}$ \\
\hline Dados Históricos & II Salăo de Arte Contemporânea de Såo Caetano do Sul (1968) \\
\hline Titulo & Pintura I \\
\hline Autor & Aluisio dos Santos \\
\hline Data de Produção & s/d \\
\hline Técnica & Mista sobre madeira \\
\hline Dimensōes & $61 \times 31 \mathrm{~cm}$ \\
\hline Dados Históricos & III Salâo de Arte Contemporânea de São Caetano do Sul (1969) \\
\hline Titulo & Pintura II \\
\hline Autor & Aluisio dos Santos \\
\hline Data de Produção & $\mathbf{s} / \mathbf{d}$ \\
\hline Técnica & Mista sobre madeira \\
\hline Dimensōes & $61 \times 31 \mathrm{~cm}$ \\
\hline Dados Históricos & III Salão de Arte Contemporânea de São Caetano do Sul (1969) \\
\hline Titulo & Pintura III \\
\hline Autor & Aluisio dos Santos \\
\hline Data de Produção & s/d \\
\hline Técnica & Mista sobre madeira \\
\hline Dimensōes & $61 \times 31 \mathrm{~cm}$ \\
\hline Dados Históricos & III Salāo de Arte Contemporânea de Săo Caetano do Sul (1969) \\
\hline Titulo & Formas em decadência \\
\hline Autor & Luiz Nade Piccinini \\
\hline Data de Produção & 1969 \\
\hline Técnica & Mista sobre papel \\
\hline Dimensōes & $60 \times 60 \mathrm{~cm}$ \\
\hline Dados Históricos & III Salão de Arte Contemporánea de São Caetano do Sul (1969) \\
\hline Titulo & Construção I \\
\hline Autor & Regis M. da Silva \\
\hline Data de Produção & $1968 / 1969$ \\
\hline Técnica & Assemblagem \\
\hline Dimensōes & $65 \times 85 \mathrm{~cm}$ \\
\hline Dados Históricos & III Salão de Arte Contemporănea de São Caetano do Sul (1969) \\
\hline
\end{tabular}


Fundação Pró-Memória de São Caetano do Sul

Pinacoteca Municipal

Obras dos Salões de Arte Contemporânea

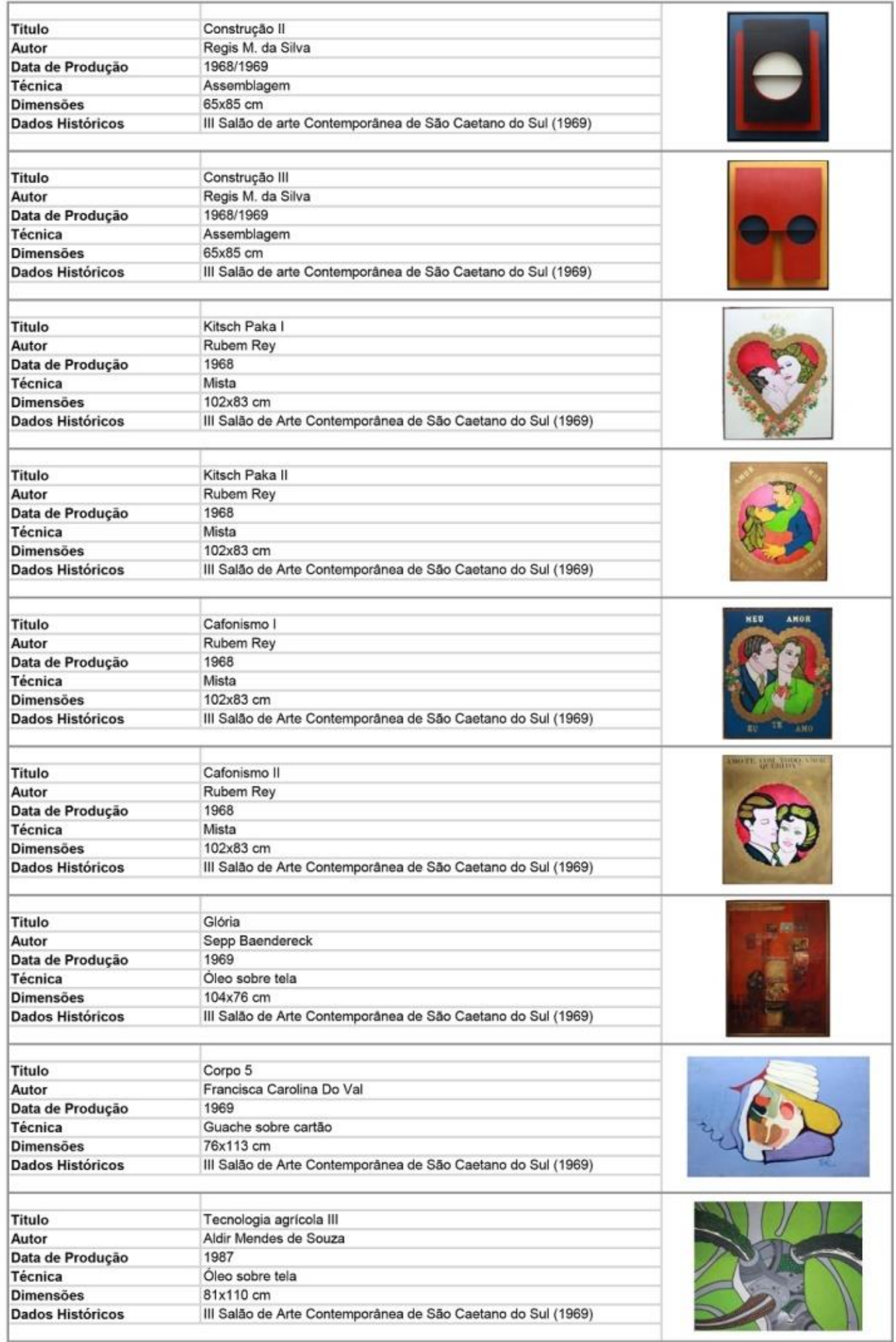


Fundação Pró-Memória de São Caetano do Sul Pinacoteca Municipal

Obras dos Salōes de Arte Contemporânea

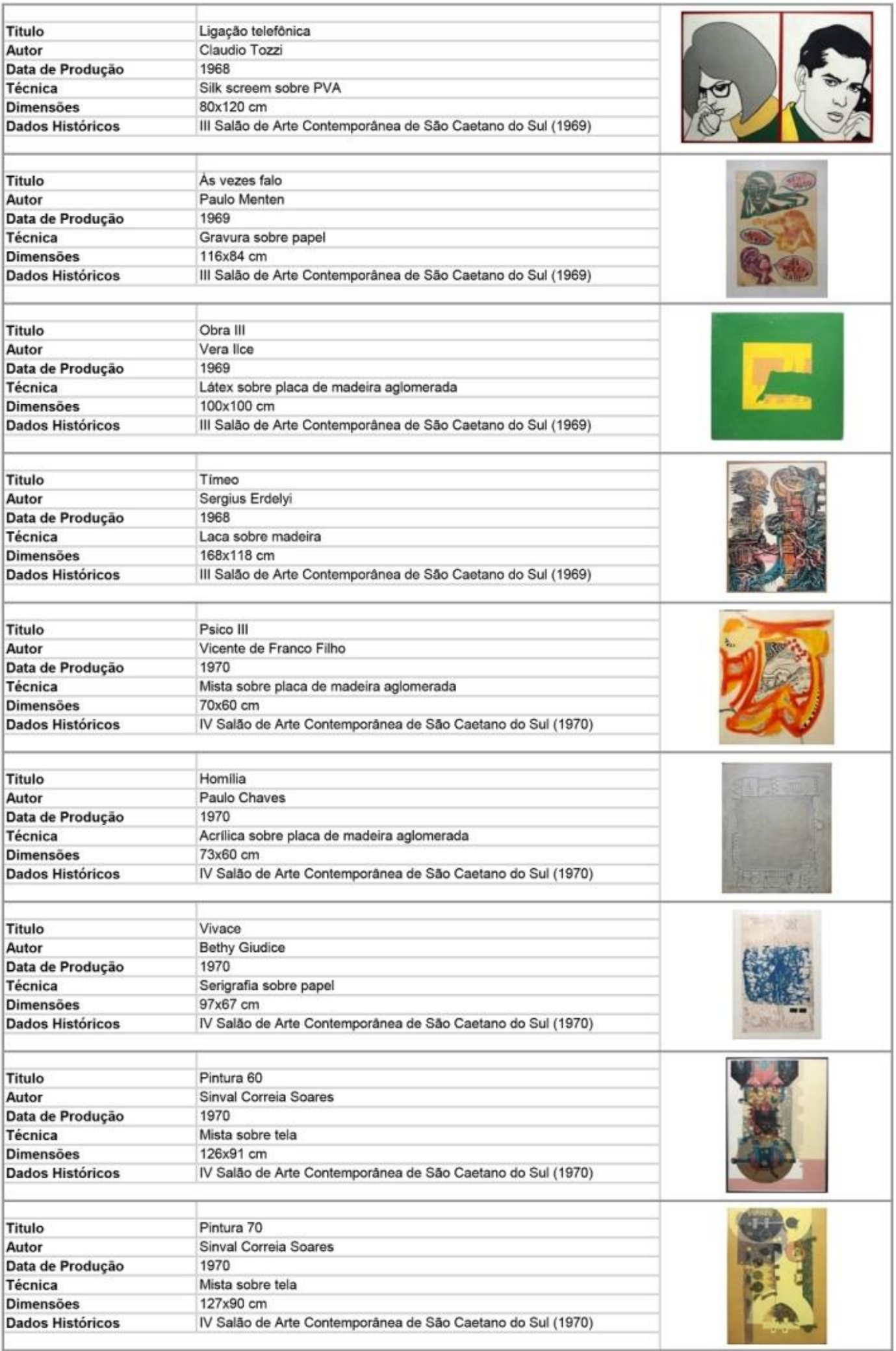


Fundação Pró-Memória de São Caetano do Sul Pinacoteca Municipal

Obras dos Salões de Arte Contemporânea

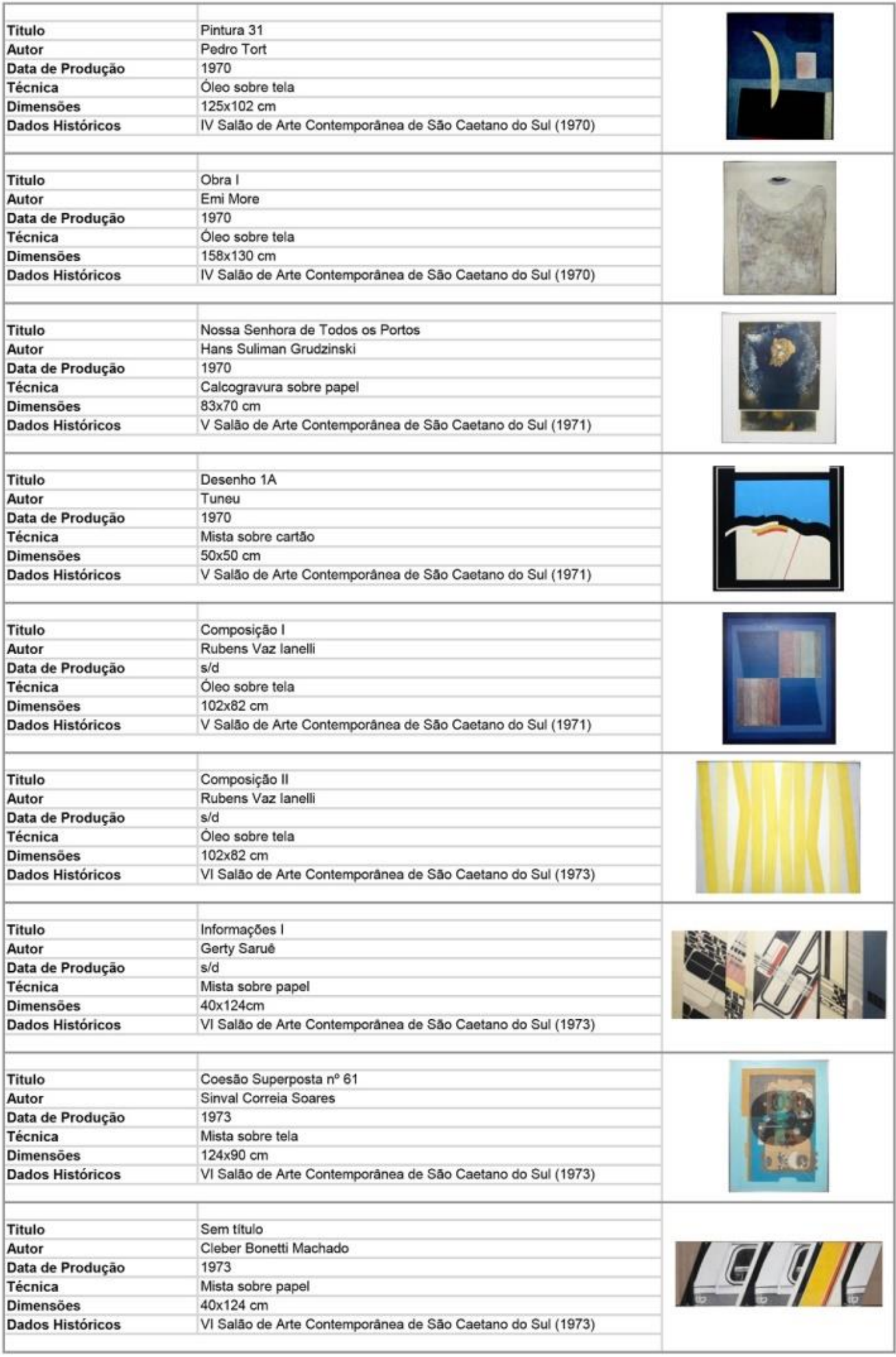


Fundação Pró-Memória de São Caetano do Sul Pinacoteca Municipal

Obras dos Salões de Arte Contemporânea

\begin{tabular}{|c|c|c|}
\hline Titulo & Paisagem II & \multirow{12}{*}{ 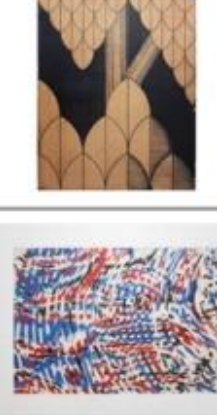 } \\
\hline Autor & Romão Bertoncel & \\
\hline Data de Produçào & 1973 & \\
\hline Técnica & Hidrográfica sobre cartão & \\
\hline Dimensōes & $70 \times 90 \mathrm{~cm}$ & \\
\hline Dados Históricos & VI Salăo de Arte Contemporånea de São Caetano do Sul (1973) & \\
\hline Titulo & Composição no Espaço & \\
\hline Autor & Therezinha Rimoli & \\
\hline Data de Produçāo & 1973 & \\
\hline Técnica & Colagem sobre papel & \\
\hline Dimensōes & $66 \times 84 \mathrm{~cm}$ & \\
\hline Dados Históricos & VI Salão de Arte Contemporânea de Sâo Caetano do Sul (1973) & \\
\hline Titulo & Clarões XVIII & \\
\hline Autor & Vania Pereira & \\
\hline Data de Produção & 1973 & \\
\hline Técnica & Calcogravura sobre papel & \\
\hline Dimensōes & $75 \times 75 \mathrm{~cm}$ & \\
\hline Dados Históricos & VI Salão de Arte Contemporânea de São Caetano do Sul (1973) & \\
\hline Titulo & As meninas & \\
\hline Autor & Lucilia de Toledo Mezzotero & \\
\hline Data de Produçāo & 1973 & \\
\hline Técnica & Xilogravura sobre papel & \\
\hline Dimensōes & $61 \times 70 \mathrm{~cm}$ & \\
\hline Dados Históricos & VI Salăo de Arte Contemporånea de Săo Caetano do Sul (1973) & \\
\hline Titulo & Magia 3 & \\
\hline Autor & Joăo Suzuki & \\
\hline Data de Produção & 1971 & \\
\hline Técnica & Mista sobre tela & \\
\hline Dimensöes & $98 \times 68 \mathrm{~cm}$ & \\
\hline Dados Históricos & I Salăo de Arte Contemporånea de Såo Caetano do Sul (1967) & \\
\hline Titulo & Corpo Feminino II & \\
\hline Autor & Emi More & \\
\hline Data de Produção & 1974 & \\
\hline Técnica & Acrilica sobre tela & \\
\hline Dimensöes & $100 \times 130 \mathrm{~cm}$ & \\
\hline Dados Históricos & VII Salão de Arte Contemporánea de São Caetano do Sul (1974) & \\
\hline Titulo & Desenho II & \\
\hline Autor & Lya Amaral Souza & \\
\hline Data de Produção & s/d & \\
\hline Técnica & Mista sobre papel & \\
\hline Dimensōes & $68 \times 97 \mathrm{~cm}$ & \\
\hline Dados Históricos & VII Salåo de Arte Contemporånea de Săo Caetano do Sul (1974) & \\
\hline Titulo & Blindado IV & \\
\hline Autor & Charbel & \\
\hline Data de Produção & s/d & \\
\hline Técnica & Assemblage & \\
\hline Dimensōes & $81 \times 65 \mathrm{~cm}$ & \\
\hline Dados Históricos & VII Salăo de Arte Contemporânea de Săo Caetano do Sul (1974) & \\
\hline Titulo & Protese I & \\
\hline Autor & Romildo Paiva & \\
\hline Data de Produção & $s / d$ & \\
\hline Técnica & Gravura sobre papel & \\
\hline Dimensöes & $80 \times 60 \mathrm{~cm}$ & \\
\hline Dados Históricos & VII Salão de Arte Contemporânea de São Caetano do Sul (1974) & \\
\hline
\end{tabular}


Fundação Pró-Memória de São Caetano do Sul

Pinacoteca Municipal

Obras dos Salões de Arte Contemporânea

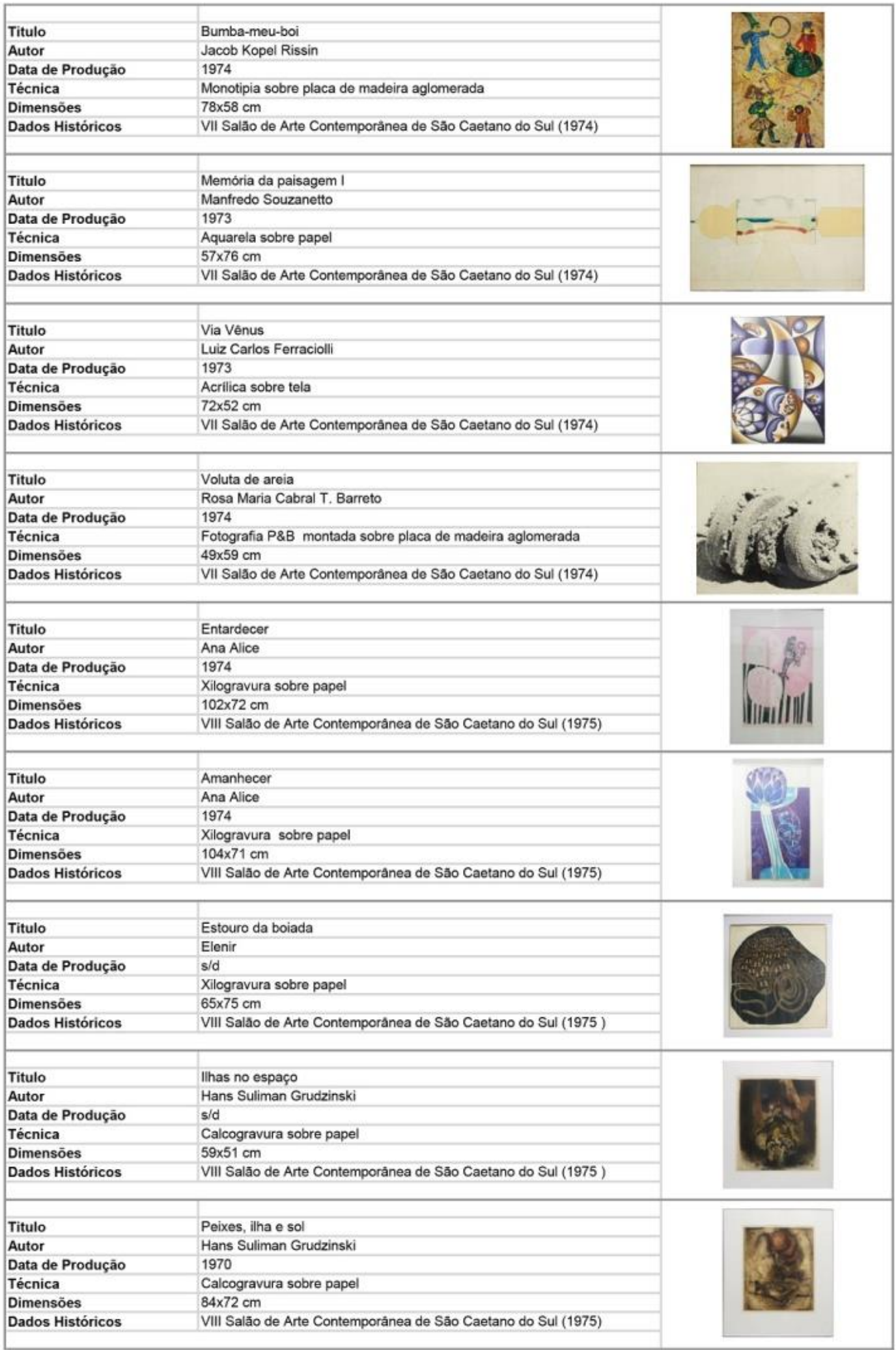


Fundação Pró-Memória de São Caetano do Sul

Pinacoteca Municipal

Obras dos Salões de Arte Contemporânea

\begin{tabular}{|c|c|c|}
\hline Titulo & Intereferência | & \\
\hline Âuior & Claudio Tozzi & \\
\hline Data de Produção & 1974 & \\
\hline Técnica & Serigrafia sobre papel & \\
\hline Dimensöes & $56 \times 56 \mathrm{~cm}$ & \\
\hline Dados Históricos & VIII Salão de Arte Contemporânea de São Caetano do Sul (1975) & 2 \\
\hline Titulo & Interferência II & \\
\hline Autor & Claudio Tozzi & \\
\hline Data de Produção & $1974 / 1975$ & \\
\hline Técnica & Serigraía sobre papei & \\
\hline Dimensöes & $56 \times 56 \mathrm{~cm}$ & \\
\hline Dados Históricos & VIII Saläo de Arte Contemporânea de São Caetano do Sul (1975) & \\
\hline Tituilo & Interferência ili & \\
\hline Autor & Claudio Tozzi & \\
\hline Data de Produção & $1973 / 74$ & \\
\hline Técnica & Serigrafia sobre papel & \\
\hline Dimensões & $56 \times 56 \mathrm{~cm}$ & \\
\hline Daados riisióricos & Viii Sảão de Arte Contemporânea de São Caetano do Sui (1975) & \\
\hline Titulo & Evoluçäo A & \\
\hline Autor & Kenichi Kaneko & \\
\hline Data de Froduçăo & sid & \\
\hline Técnica & Serigrafia sobre papel & \\
\hline Dimensöes & $50 \times 50 \mathrm{~cm}$ & \\
\hline Dados Históricos & VIII Salão de Arte Contemporânea de São Caetano do Sul (1975) & \\
\hline Titulo & Evolução B & \\
\hline Autor & Kenichi Kaneko & 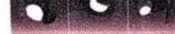 \\
\hline Data de Produção & $s / d$ & \\
\hline Técnica & Serigrafia sobre papel & \\
\hline Dimensöes & $60 \times 84 \mathrm{~cm}$ & \\
\hline Dados Históricos & VIII Salão de Arte Contemporânea de São Caetano do Sul (1975 ) & . \\
\hline Titulo & Evolução & A. \\
\hline Autor & Kenichi Kaneko & \\
\hline Data de Produçäo & $s / d$ & \\
\hline Técnica & Serigrafia sobre papel & \\
\hline Dimensöes & $50 \times 50 \mathrm{~cm}$ & a \\
\hline Dados Históricos & VIII Salăo de Arte Contemporânea de São Caetano do Sul (1975) & W \\
\hline Titulo & Condicionamento $\mathrm{A}$ & \\
\hline Autor & Romildo Paiva & \\
\hline Data de Produçäo & 1975 & \\
\hline Técnicã & Calcogravura sobre pape! & \\
\hline Dimensöes & $53 \times 79 \mathrm{~cm}$ & \\
\hline Dados Históricos & VIII Saläo de Arte Contemporânea de São Caetano do Sul (1975) & \\
\hline Titule & Condicionamento $\mathrm{B}$ & \\
\hline Autor & Romildo Paiva & \\
\hline Data de Produção & 1974 & \\
\hline Técnica & Calcogravura sobre papel & \\
\hline Dimensöes & $63 \times 83 \mathrm{~cm}$ & \\
\hline Daúos Históricos & VIII Salăo de Arte Contemporânea de Săo Caetano do Sul (1975) & \\
\hline Titulo & Sem titulo A & \\
\hline Autor & Marilia Saboya & \\
\hline Data de Produção & 1974 & \\
\hline Técnica & Serigrafia sobre papel & (2) \\
\hline Dimensöes & $72 \times 58 \mathrm{~cm}$ & \\
\hline Dados Históricos & VIII Saläo de Arte Contemporânea de São Caetano do Sul (1975) & \\
\hline
\end{tabular}


Fundação Pró-Memória de São Caetano do Sul

Pinacoteca Municipal

Obras dos Salões de Arte Contemporânea

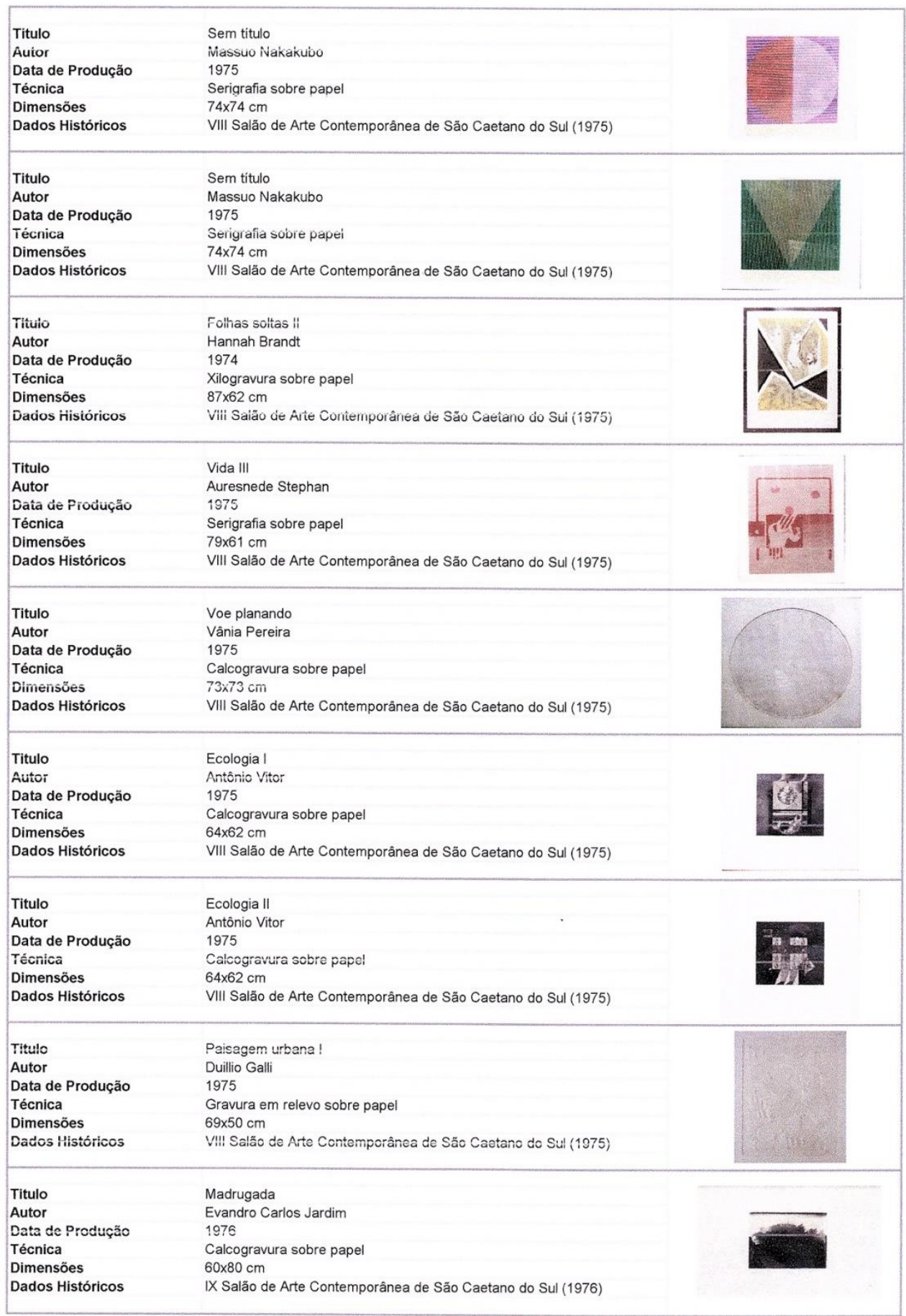


Fundação Pró-Memória de São Caetano do Sul

Pinacoteca Municipal

Obras dos Salōes de Arte Contemporânea

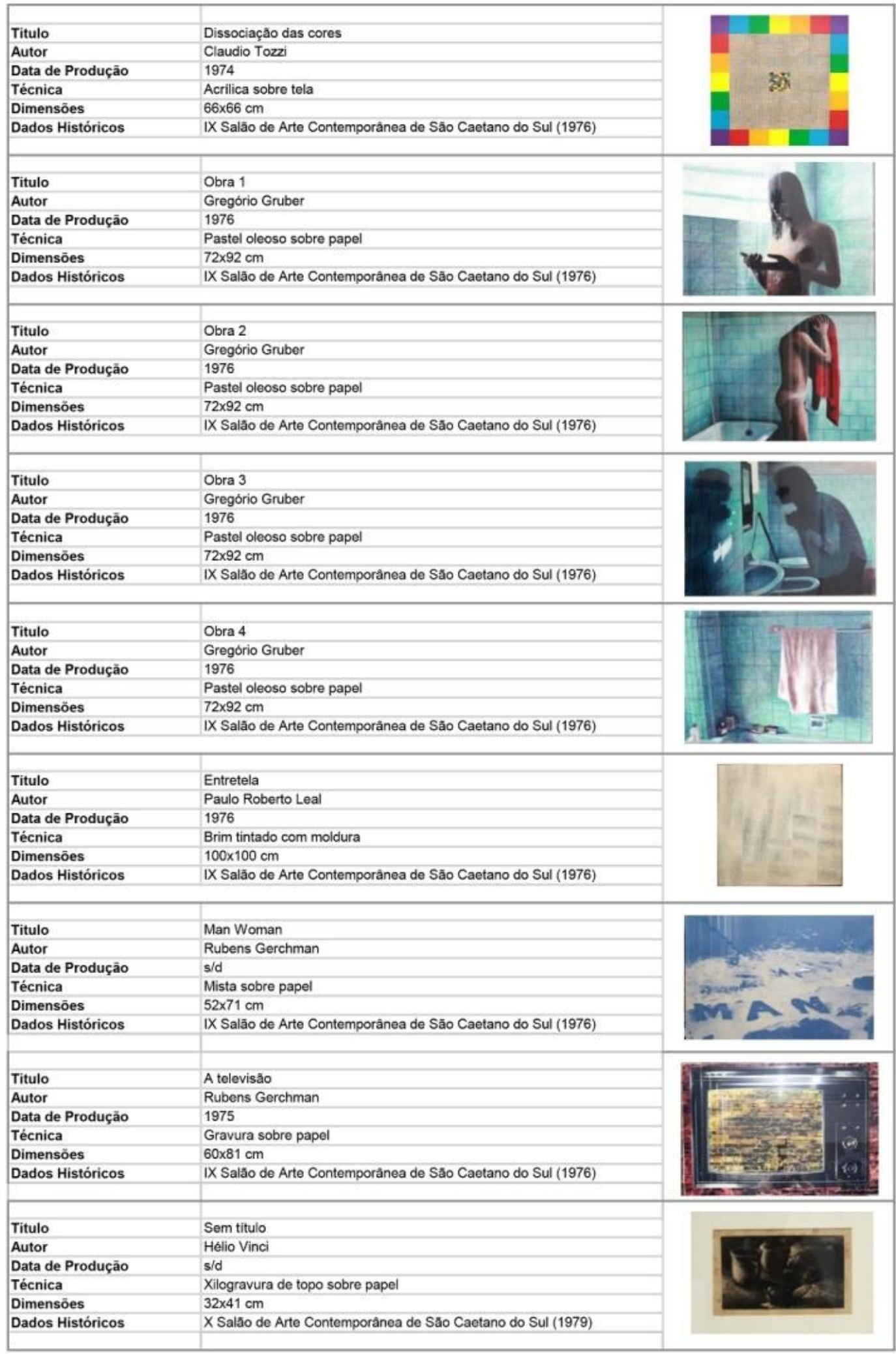


Fundação Pró-Memória de São Caetano do Sul

Pinacoteca Municipal

Obras dos Salões de Arte Contemporânea

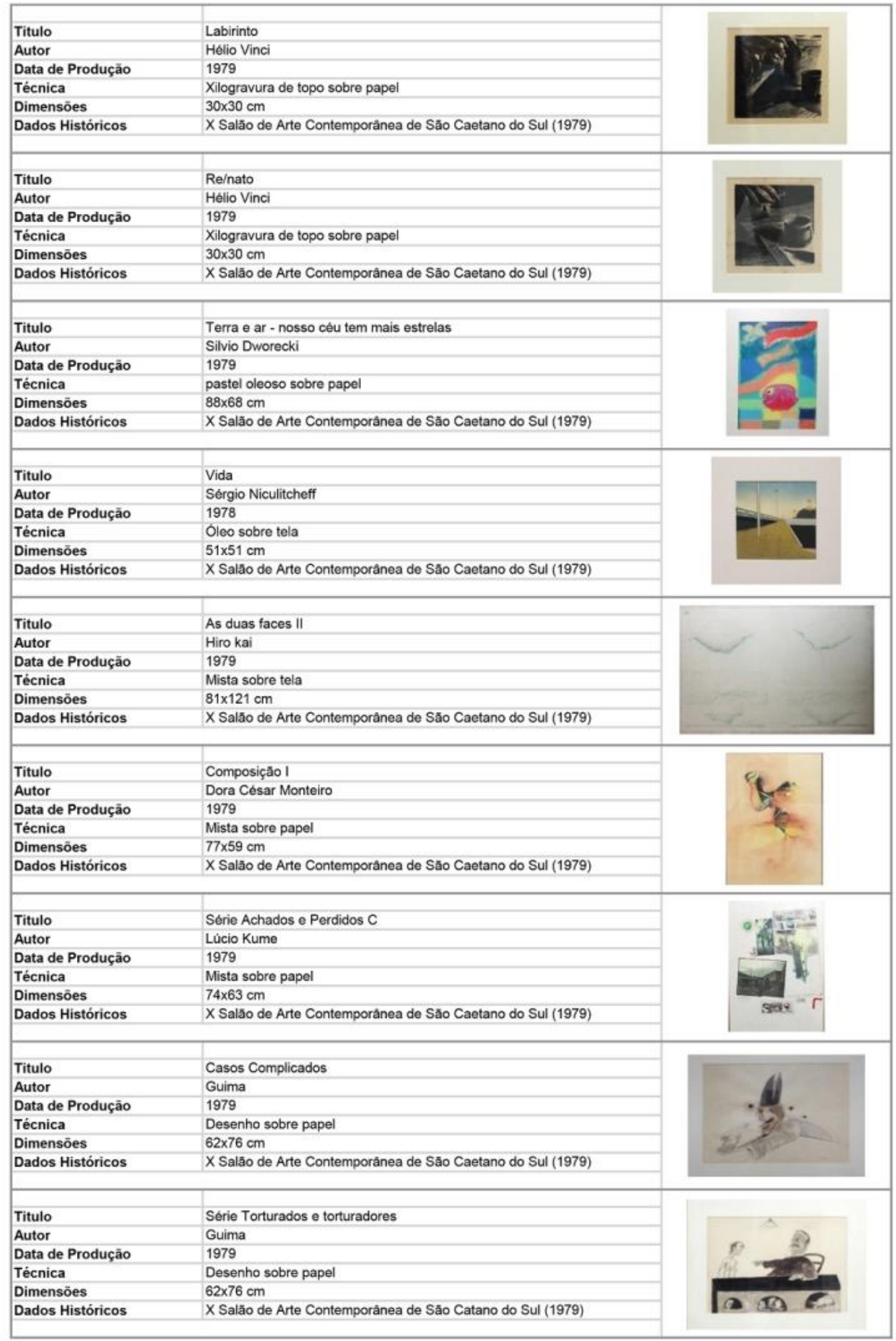


Fundação Pró-Memória de São Caetano do Sul

Pinacoteca Municipal

Obras dos Salōes de Arte Contemporânea

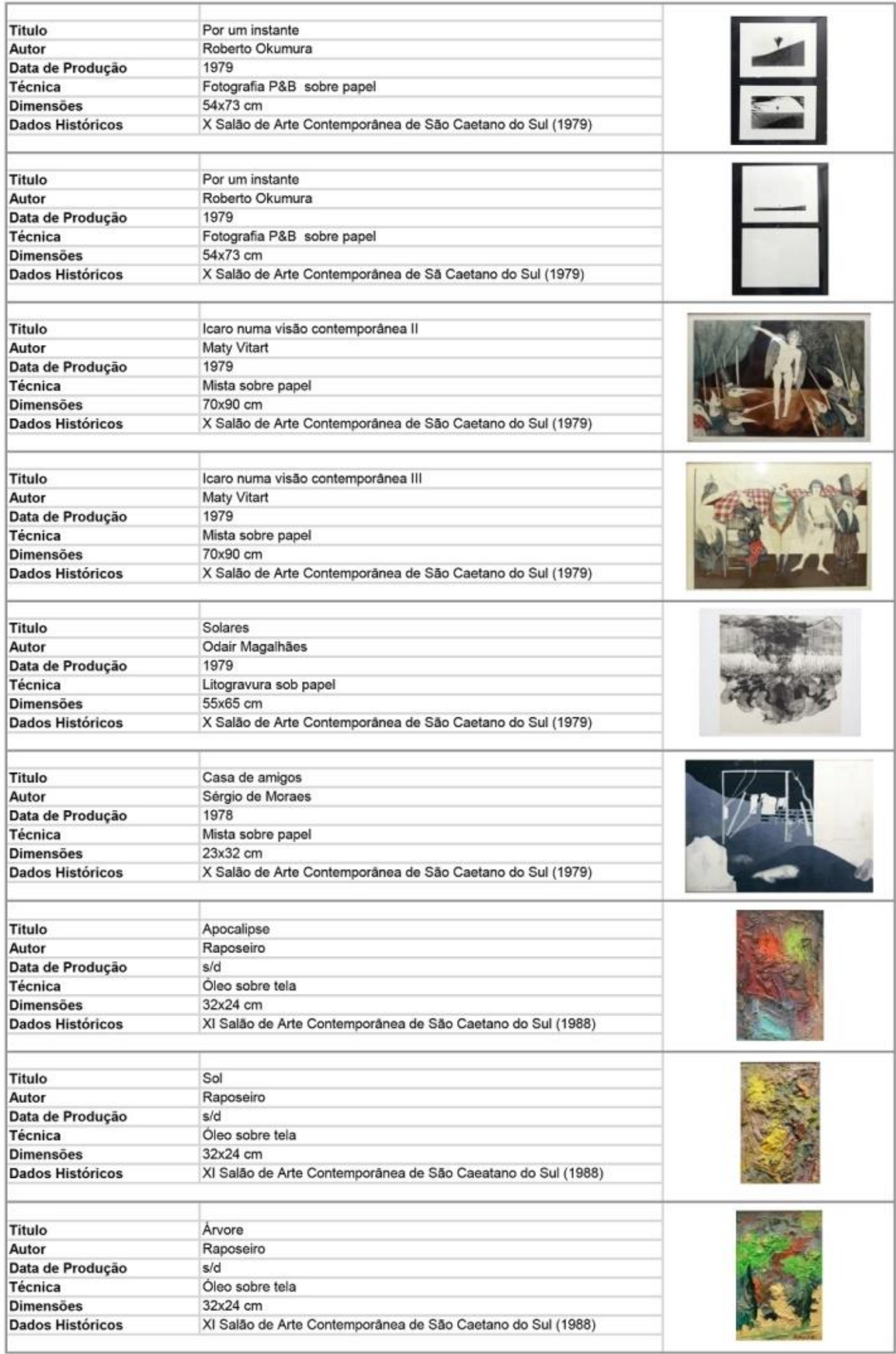


Fundação Pró-Memória de São Caetano do Sul

Pinacoteca Municipal

Obras dos Salões de Arte Contemporânea

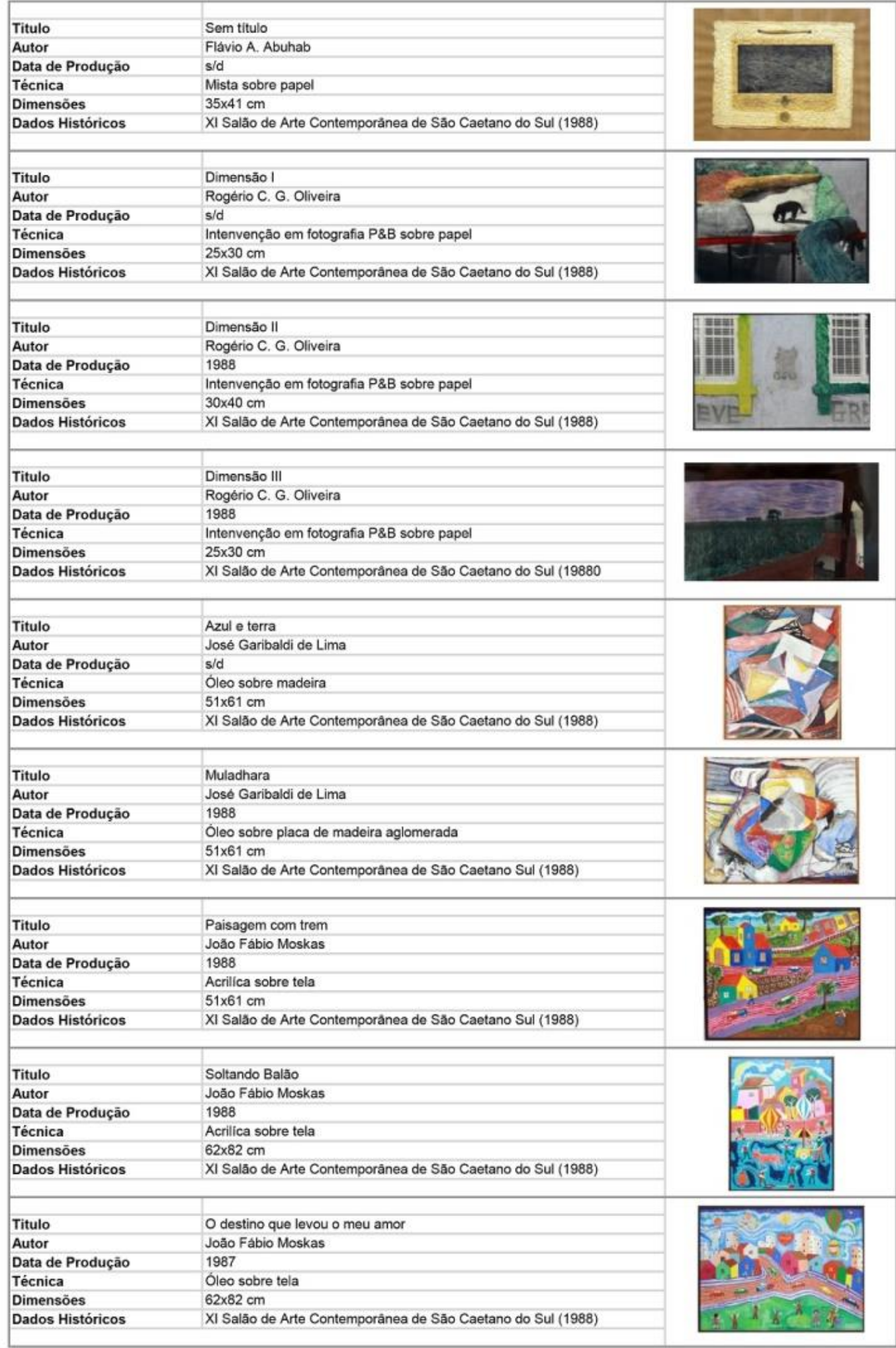


Fundação Pró-Memória de São Caetano do Sul

Pinacoteca Municipal

Obras dos Salões de Arte Contemporânea

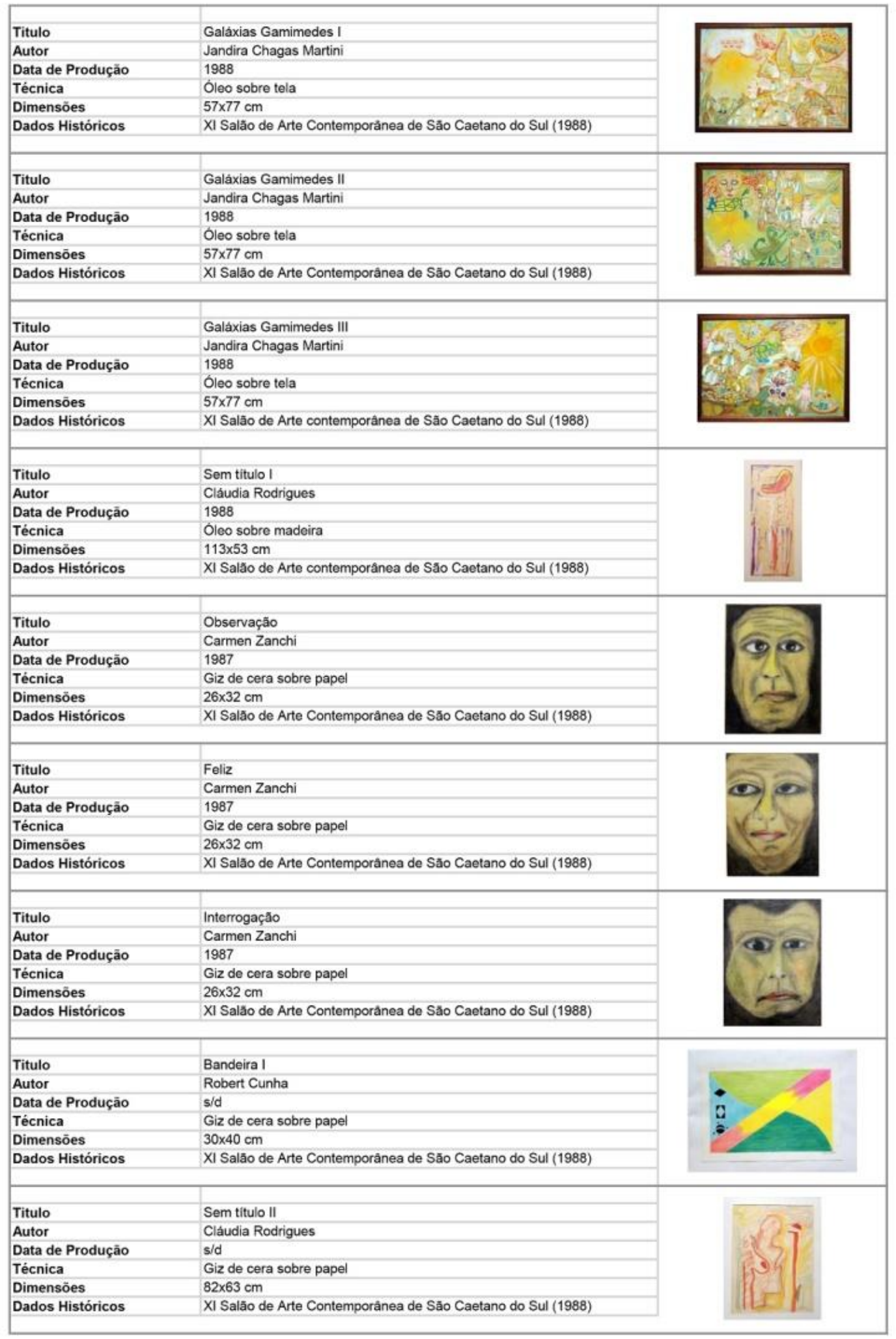




\author{
ANEXO D \\ FICHA TÉCNICA \\ SALÕES DE ARTE CONTEMPORÂNEA DE SÃO CAETANO DO SUL
}

\title{
I SALÃO DE ARTE CONTEMPORÂNEA DE SÃO CAETANO DO SUL
}

\section{REALIZAÇÃO:}

Prefeitura Municipal de São Caetano do Sul

Departamento de Educação e Cultura

Administração Hermógenes Walter Braido

LOCAL: Edifício Del Rey - Rua Baraldi, 1005 1a andar - Bairro Centro

DATA: 30 de julho a 30 de agosto de 1967

CAPA DO CATÁLOGO: Sinval Correia Soares

\section{COMISSÃO ORGANIZADORA / EXECUTIVA:}

Oscar Garbelotto (presidente) Diretor Departamento de Educação e Cultura

Alberto Aliberti

Arnaldo Ferrari

Milton Andrade

Sinval Correia Soares

COMISSÃO DE SELEÇÃO E JULGAMENTO:

Arnaldo Ferrari (presidente) *

Alberto Aliberti *

José Geraldo Vieira **

Mario Schemberg **

Walter Levy **

* indicados pela Comissão Executiva

** escolhidos pelos artistas inscritos 


\section{RELAÇÃO DOS PRÊMIOS:}

\section{Prêmio Prefeitura Municipal de São Caetano do Sul}

Seção I (Pintura) - 1ำ prêmio NCr\$ 600,00 / 2 Prêmio NCr\$ 400.00

Seção II (Escultura) - 1ำ prêmio NCr\$600,00 / 2ำPrêmio NCr\$ 400.00

Seção III (Arte Gráfica)- 1ำ prêmio NCr $\$ 400,00$ / 2ำ prêmio NCr $\$ 200,00$

Seção IV (Artes Decorativas) - 1ำ prêmio NCr\$ 400,00 / 2ำ prêmio NCr $\$ 200,00$

\section{Prêmios Honoríficos (Medalhas de Ouro, Prata e Bronze)}

\section{RELAÇÃO DE ARTISTAS PREMIADOS:}

Prêmio Prefeitura Municipal de São Caetano do Sul

Seção I (Pintura) $-1^{\circ}$ prêmio

Hermelindo Fiaminghi

- Reticulação Luz 1/10

- Reticulação Luz 1/10

- Reticulação Luz 1/10

Seção I (Pintura) - 2ำ prêmio

Heinz Kühn

* Reflexo III

Ubirajara Molina Ribeiro

* Robot

Seção II (Escultura) - 1ำ prêmio

Lourdes Therezinha Silva de Amorin Cedran

* Casa do Pássaro Flôr

Mari Yoshimoto

* Escultura X

OBS.: As duas artistas dividiram o primeiro lugar e como não houve segundo lugar receberam

Seção III (Arte Gráfica) - 1ำ prêmio

Niobe Xandó

- Quadro I

Seção III (Arte Gráfica) - 2º prêmio 
João Suzuki

- Menino dentro de mim que não quer a pomba morta

Massuo Nakakubo

- Desenho 16

* As obras assim assinaladas não constam na Coleção dos Salões de Arte Contemporânea de São Caetano do Sul

\section{Prêmios Honoríficos}

Seção I (Pintura) - Medalha de Ouro

Paulo Mentem

Rosa Shiroma Bersani

Rubem Rey

Seção I (Pintura) - Medalha de Prata

Aldir Mendes de Souza

Kenichi Kaneco

Paulo Chaves

Vinicio Pradella

Seção I (Pintura) - Medalha de Bronze

Aluizio Domingos dos Santos

Armando M. Sendin

Edison Cruz

Eisaburo Mori

Gastone Rinaldi

Hisao Shirai

José Brasiliense

Leila Regina Porto de Andrade

Maria do Carmo Gomes Lorenzini

Pavel Kudis

Sergio Pastura

Seção II (Escultura) - Medalha de Bronze

Joaquim Ferreira Esteves

Sulita di Franco

Seção III (Arte Gráfica) - Medalha de Prata

Hans Suliman Grudzinski 
Maria Glória Almeida Siqueira

Seção III (Arte Gráfica) - Medalha de Bronze

Alice Brill

Eunibaldo Tinôco de Souza

Jacobo

Seção IV (Artes Decorativas) - Medalha Ouro

Mariselda Brumajny

Seção IV (Artes Decorativas) - Medalha Bronze

Alba Regina Dias de Souza

Antonio Carelli

Delson Pedroso

Marina Salerno Raimo

Renato Wagner

\section{ARTISTAS HORS CONCOURS}

Alberto Aliberti

* Relógio (escultura)

Arnaldo Ferrari

* Composição XX (pintura)

Sinval Correia

* Coesão no 20 (pintura) 
FICHA TÉCNICA

SALÕES DE ARTE CONTEMPORÂNEA DE SÃO CAETANO DO SUL

II SALÃO DE ARTE CONTEMPORÂNEA DE SÃo CAETANO DO SUL

REALIZAÇÃO:

Prefeitura Municipal de São Caetano do Sul

Departamento de Educação e Cultura

Administração Hermógenes Walter Braido

Tijucussú Clube de São Caetano do Sul (colaboração)

LOCAL: Colégio Estadual Idalina Macedo da Costa Sodré - Avenida Goiás - Bairro Barcelona

DATA: 07 a 30 de julho de 1968

CAPA DO CATÁLOGO: Sinval Correia Soares

COMISSÃO ORGANIZADORA / EXECUTIVA:

Oscar Garbelotto (presidente) Diretor Departamento de Educação e Cultura

Alberto Aliberti

Fábio Magalhães

Maurício Nogueira Lima

Sinval Correia Soares

Coordenação

Antônio Carelli

Milton Andrade

Relações Públicas

Paulo Augusto Bueno Wolf

COMISSÃO DE SELEÇÃO E JULGAMENTO:

Alberto Aliberti (presidente)

Hermelindo Fiaminghi

José Geraldo Vieira 
Mario Schemberg

Sinval Correia Soares

RELAÇÃO DOS PRÊMIOS:

Prêmio Prefeito Hermógenes Walter Braido

$\mathrm{NCr} \$ 2.000,00$

\section{Prêmio Prefeitura Municipal de São Caetano do Sul}

Seção I (Pintura) - 1ํo prêmio NCr\$1.000,00 / 2ำ Prêmio NCr\$ 500.00

Seção II (Escultura) - 1ำ prêmio NCr $\$ 1.000,00$ / 2º Prêmio NCr $\$ 500.00$

Seção III (Arte Gráfica) - 1ำ prêmio NCr\$1.000,00 / ำ prêmio NCr\$ 500,00

Seção IV (Artes Decorativas) - 1ำ prêmio NCr\$1.000,00 / 2ํㅜ prêmio NCr $\$ 500,00$

\section{RELAÇÃO DE ARTISTAS PREMIADOS:}

Prêmio Prefeito Hermógenes Walter Braido

João Parisi Filho

- Cinema I

- Cinema II

- Cinema III

Prêmio Prefeitura Municipal de São Caetano do Sul

Seção I (Pintura) - 1ํo prêmio

Antônio Henrique A. Amaral

- Incomunicação

Seção I (Pintura) - $2^{\circ}$ prêmio

Humberto Augusto Miranda Espíndola

- Na espera do dinheiro do boi

Seção II (Escultura) - 1ำ prêmio

Leila Porto de Andrade

* Caixa II

Seção II (Escultura) - 2º prêmio

Aldir Mendes de Souza

* Metropolização em plataformas II 
Seção III (Arte Gráfica) - 1ํo prêmio

Ubirajara M. L. Ribeiro

- O Vampiro

- O Cinema

- A Cópula

Seção III (Arte Gráfica) - 2ํㅜ prêmio

Vera llce

* Desenho I

* Desenho II

* Desenho III

Seção IV (Artes Decorativas) - 10 prêmio

Manuel de Matos Vinagre - Bandarra

- Genesis

Seção IV (Artes Decorativas) - 2ํo prêmio

Ernestina Karman

- Esquadrilha

As obras assim assinaladas não constam na Coleção dos Salões de Arte Contemporânea de São Caetano do Sul

\section{SALA ESPECIAL}

Mostra Retrospectiva de Arnaldo Ferrari

Textos de Mário Schenberg e Theon Spanudis 
FICHAS TÉCNICAS

SALÕES DE ARTE CONTEMPORÂNEA DE SÃO CAETANO DO SUL

\section{SALÃO DE ARTE CONTEMPORÂNEA DE SÃO CAETANO DO SUL}

\section{REALIZAÇÃO:}

Prefeitura Municipal de São Caetano do Sul

Departamento de Educação e Cultura

Administração Oswaldo Samuel Massei

LOCAL: Edifício da Associação dos Professores - Rua Alegre, 497 - Bairro Barcelona

DATA: 26 de julho a 24 de agosto de 1969

CAPA DO CATÁLOGO: Sinval Correia Soares

\section{COMISSÃO ORGANIZADORA / EXECUTIVA:}

Argemiro Barros Araújo (presidente) Diretor Departamento de Educação e Cultura

Alberto Aliberti

Enock Fernandes Sacramento

Hermelindo Fiaminghi

Sinval Correia Soares

\section{Coordenação}

Milton Andrade

Relações Públicas

Oto Diringer

\section{COMISSÃO DE SELEÇÃO E PREMIAÇÃO:}

Maurício Nogueira Lima (presidente) Associação Internacional de Artistas Plásticos Alberto Aliberti

Enock Fernandes Sacramento

Hermelindo Fiaminghi

Sinval Correia Soares

Associação Brasileira de Desenho Industrial - não enviou representante 


\section{RELAÇÃO DOS PRÊMIOS:}

\section{Prêmio-Aquisição}

NCr\$12.000,00 (prêmios correspondentes ao valor da obra declarado pelo artista - cada prêmio não poderia exceder NCr\$3.000,00)

\section{Prêmio-Aquisição "Chocolates Pan"}

\section{Prêmio-Participação}

Projetos, maquetes e protótipos relativos à arquitetura e desenho industrial - prêmio fixo NCr\$ 500,00

\section{RELAÇÃO DE ARTISTAS PREMIADOS:}

\section{Prêmio-Aquisição}

Aldir Mendes de Souza

- Tecnologia Agrícola III

Aluísio Domingos dos Santos

- Pintura I

- Pintura II

- Pintura III

Antônio Vitor

- Variação $1^{a}$ de um tema patético

Armando M. Sendin

* Mater

Cláudio Tozzi

- A ligação telefônica

Dalton Salem Asseff

- Duas faces da moeda

Francisca Carolina do Val

- Corpos 5

Hanna Henriette Brandt

* Saída da aula Juarez Magno de Freitas Almeida

* Meheler em vigília 
Leila Porto de Andrade

* Caixa II

Lothar Charoux

* Vibração

Luiz Wade Piccinini

- Formas em decadência

Paulo Menten

- Às vezes falo

Régis Machado Silva

- Construção I

- Construção II

- Construção III

Sepp Baendereck

- Glória

Sergius Erdelyi

- Timeo

Vera llse

- Obra III

Prêmio-Aquisição "Chocolates Pan"

Francisca Carolina do Val

* Corpos 3-4

\section{Prêmio-Participação}

Pedro Moacyr de Campos Jr.

* Transporte Polivalente Urbano (desenho industrial)

* As obras assim assinaladas não constam na Coleção dos Salões de Arte Contemporânea de São Caetano do Sul 
FICHAS TÉCNICAS

SALÕES DE ARTE CONTEMPORÂNEA DE SÃO CAETANO DO SUL

IV SALÃO DE ARTE CONTEMPORÂNEA DE SÃO CAETANO DO SUL

REALIZAÇÃO:

Prefeitura Municipal de São Caetano do Sul

Departamento de Educação e Cultura

Administração Oswaldo Samuel Massei

LOCAL: Fundação das Artes - Rua Visconde de Inhaúma, 730 - Vila Gerte

DATA: 12 de dezembro de 1970 a 31 de janeiro de 1971

CAPA DO CATÁLOGO: Pedro Font Savall

COMISSÃO ORGANIZADORA / EXECUTIVA:

Argemiro Barros Araújo (diretor DEPEC) presidente

Alberto Aliberti

Enock Fernandes Sacramento

Hermelindo Fiaminghi

\section{Coordenação}

Milton Andrade

COMISSÃO DE SELEÇÃO E PREMIAÇÃO:

Arcangelo lanelli (presidente)

Enock Fernandes Sacramento

Hermelindo Fiaminghi

José Armando Pereira da Silva

Maurício Nogueira Lima 


\section{RELAÇÃO DOS PRÊMIOS:}

\section{Prêmio-Aquisição}

Cr\$12.000,00 (prêmios correspondentes ao valor da obra declarado pelo artista - cada prêmio não poderia exceder $\operatorname{Cr} \$ 3.000,00)$

Prêmios Honoríficos (Menção Especial de Mérito)

\section{RELAÇÃO DE ARTISTAS PREMIADOS:}

\section{Prêmios Aquisição}

Bethy B. Monteiro Giudice

- Vivace

Emi Mori

- Obra I

Eveline Borges

- Da festa de macucos nos matos do brejo de Abrolhos

Gabriel Borba Filho

- Nife III (escultura)

Hannah Henriette Brandt

* Campos

Iracy de Almeida Puccini

* Pintura 1

Maria Olímpia Vassão

* Inominável I

* Inominável II

Paulo Chaves

- Homilia

Pedro Tort

- Pintura № 31

Raphael da Costa

- Bolhas em Formas

Romildo Paiva

* Homem e a máquina I

Sérgio Fingermann

* Gravura III 
Sinval Correia Soares

- Pintura nำ60

- Pintura no 70

Sonia Von Brusky

* Sibarismo diabólico

Vicente de Franco Filho

- Pisico III

As obras assim assinaladas não constam na Coleção dos Salões de Arte Contemporânea de São Caetano do Sul

Prêmios Honoríficos (Menção Especial de Mérito)

Aldir Mendes de Souza

Cláudio Tozzi

Lothar Charoux

Niobe Xandó

Regis Machado Silva

Vera llse Cruz 
FICHAS TÉCNICAS

SALÕES DE ARTE CONTEMPORÂNEA DE SÃO CAETANO DO SUL

\section{SALÃO DE ARTE CONTEMPORÂNEA DE SÃO CAETANO DO SUL}

\section{REALIZAÇÃO:}

Prefeitura Municipal de São Caetano do Sul

Departamento de Educação e Cultura

Administração Oswaldo Samuel Massei

LOCAL: Fundação das Artes - Rua Visconde de Inhaúma, 730 - Vila Gerte

DATA: 14 de outubro a 15 de novembro de 1971

\section{CAPA DO CATÁLOGO:}

\section{COMISSÃO ORGANIZADORA / EXECUTIVA:}

Alberto Aliberti (presidente)

Enock Fernandes Sacramento

José Armando Pereira da Silva

Milton Andrade

Sinval Correia Soares

COMISSÃO DE SELEÇÃO E PREMIAÇÃO:

Jacques Douchez - presidente

Carlos Alberto Fajardo

Enock Fernandes Sacramento

Hermelindo Fiaminghi

José Armando Pereira da Silva

\section{RELAÇÃO DOS PRÊMIOS:}

\section{Prêmio Prefeito Oswaldo Samuel Massei}

Cr\$2.000,00 (para o melhor trabalho ou conjunto de trabalhos independente do PrêmioAquisição a que fizer jus) 


\section{Prêmio-Aquisição}

$\mathrm{Cr} \$ 12.000,00$ (prêmios correspondentes ao valor da obra declarado pelo artista)

\section{Prêmio-Participação}

Projetos, maquetes e protótipos relativos à arquitetura e desenho industrial - prêmio fixo $\mathrm{Cr} \$$ 500,00

\section{RELAÇÃO DE ARTISTAS PREMIADOS:}

\section{Prêmio Prefeito Oswaldo Samuel Massei}

Antônio Lizárraga

* Portátil/notação

* Pural/fonético

* Torques/critérios

(o artista recebeu também um Prêmio-Aquisição)

\section{Prêmio-Aquisição}

Antônio Carlos Rodrigues (Tuneu)

- Desenho 1A

Aracy R. M. Zanotti

* Obsessão III

Geraldo José De Souza ("Geu")

* Mercouri III

Gerty Sarué

* Série III

Hans Suliman Grudzinski

- Nossa Senhora de todos os portos Irene Satie Shoyama

* Veduta III Vaz lanelli

- Composição I

* As obras assim assinaladas não constam na Coleção dos Salões de Arte Contemporânea de São Caetano do Sul 
FICHAS TÉCNICAS

SALÕES DE ARTE CONTEMPORÂNEA DE SÃO CAETANO DO SUL

\section{SALÃO DE ARTE CONTEMPORÂNEA DE SÃO CAETANO DO SUL}

\section{REALIZAÇÃO:}

Prefeitura Municipal de São Caetano do Sul

Departamento de Educação e Cultura

Fundação das Artes

Administração H. Walter Braido

LOCAL: Fundação das Artes - Rua Visconde de Inhaúma, 730 - Vila Gerte

DATA: 27 de julho a 26 de agosto de 1973

\section{CAPA DO CATÁLOGO:}

COMISSÃO ORGANIZADORA / EXECUTIVA:

João José Dario (presidente)

Alberto Aliberti

Enock Fernandes Sacramento

José Armando Pereira da Silva

Milton Andrade

\section{COMISSÃO DE SELEÇÃO E PREMIAÇÃO:}

Lizetta Levy (presidente)

Enock Fernandes Sacramento

Ivo Zanini

João José Dario

Romeu de Graça

\section{RELAÇÃO DOS PRÊMIOS:}

Prêmio-Aquisição

Cr\$15.000,00 (prêmios correspondentes ao valor da obra declarado pelo artista) 


\section{Prêmio-Participação}

Projetos, maquetes e protótipos relativos à arquitetura e desenho industrial - prêmio fixo $\mathrm{Cr} \$$ $1.000,00$

\section{RELAÇÃO DE ARTISTAS PREMIADOS:}

Aracy R. Monteiro Zanotti

- Tapeçaria - Grotas 5

Cesar Oscar A. Pellegrino

* Desenho III

Cleber Bonetti Machado

- Fotografia e óleo s/ papel 2

Gerty Sarué

- Informação I

Lucília de Toledo Mezzótero

- Meninas

Maria Tereza Rimoli de Graça

- Composição no espaço

Mario Marcos Tagnini

* Tudo passa...

Romão Bertoncel

- Paisagem II

Rubens lanelli

- Composição I

Sinval Correia Soares

- Coesão superposta ํㅡ 61

Vania Pereira

- Clarões VIII

* As obras assim assinaladas não constam na Coleção dos Salões de Arte Contemporânea de São Caetano do Sul 
FICHAS TÉCNICAS

SALÕES DE ARTE CONTEMPORÂNEA DE SÃO CAETANO DO SUL

\section{SALÃO DE ARTE CONTEMPORÂNEA DE SÃO CAETANO DO SUL}

\section{REALIZAÇÃO:}

Prefeitura Municipal de São Caetano do Sul

Departamento de Educação e Cultura

Fundação das Artes

Administração H. Walter Braido

LOCAL: Fundação das Artes - Rua Visconde de Inhaúma, 730 - Vila Gerte

DATA: 26 de julho a 23 de agosto de 1974

\section{CAPA DO CATÁLOGO:}

COMISSÃO ORGANIZADORA / EXECUTIVA:

João José Dario (presidente)

Milton Andrade

Enock Sacramento

José Armando Pereira da Silva

Frederico Reinaldo de Mattos

COMISSÃO DE SELEÇÃO E PREMIAÇÃO:

Lisetta Levi (presidente)

Enock Fernandes Sacramento

Ivo Zanini

José Armando Pereira da Silva

Joseph M. Luyten 


\section{RELAÇÃO DOS PRÊMIOS:}

\section{Prêmio-Aquisição}

Cr\$20.000,00 (prêmios correspondentes ao valor da obra declarado pelo artista)

\section{Prêmio-Participação}

Projetos, maquetes e protótipos relativos à arquitetura e desenho industrial - prêmio fixo Cr\$ $1.000,00$

\section{RELAÇÃO DE ARTISTAS PREMIADOS:}

Charbel Hanna El Ottra

- Blindado V 4

Eduardo Fontes Hotz

* Paisagem Natural (Conservação ?)

Emiko Mori

- Corpo Feminino II

Ilsa Leal Ferreira

* Ritmo I

J. Rissin

- Bumba meu boi (fig. 2)

João K. Suzuki

- Magia ํㅡ 3

Luis Carlos Ferracioli

- Via Vênus

Lya Amaral Souza

- Desenho II

Manfredo Souza Neto

- Memória da Paisagem I

Odair Magalhães

* Ultrapassando... É agora

Regis Machado Silva

* Composição III

Romildo Paiva

- Prótese I 
Rosa Maria Cabral Trindade Barreto

- Voluta de Areia

Wilson Rodrigues de Moraes

* A Cerimônia Secreta

As obras assim assinaladas não constam na Coleção dos Salões de Arte Contemporânea de São Caetano do Sul 
FICHAS TÉCNICAS

SALÕES DE ARTE CONTEMPORÂNEA DE SÃO CAETANO DO SUL

\section{SALÃO DE ARTE CONTEMPORÂNEA DE SÃO CAETANO DO SUL}

\section{REALIZAÇÃO:}

Prefeitura Municipal de São Caetano do Sul

Departamento de Educação e Cultura

Fundação das Artes

Administração H. Walter Braido

LOCAL: Fundação das Artes - Rua Visconde de Inhaúma, 730 - Vila Gerte

DATA: 18 de julho a 16 de agosto de 1975

\section{CAPA DO CATÁLOGO:}

Manuel Reis (Catálogo)

Romildo Paiva (Cartaz)

\section{COMISSÃO ORGANIZADORA / EXECUTIVA:}

João José Dario (presidente)

Enock Sacramento

José Armando Pereira da Silva

José Carlos Oliveira

Milton Andrade

COMISSÃO DE SELEÇÃO E PREMIAÇÃO:

Wolfgang Pfeiffer (presidente)

Enock Fernandes Sacramento

Lisetta Levi

Milton Andrade

Olney Krüse 


\section{RELAÇÃO DOS PRÊMIOS:}

\section{Prêmio-Aquisição}

Cr\$25.000,00 (prêmios correspondentes ao valor da obra declarado pelo artista)

Prêmios Honoríficos (Menção Especial-Pesquisa)

\section{RELAÇÃO DE ARTISTAS PREMIADOS:}

Antônio Vitor

- Série Ecológica ํำ 1

- Série Ecológica ํㅜㄴ

Auresnede Pires Stephan

- Vida III

Cláudio Tozzi

- Interferência I

- Interferência II

- Interferência III

Duilio Galli

- Paisagem Urbana I

Hanna Henriette Brandt

- Folhas Soltas II

Hans s. Grudzinski

- Peixes, Ilha e Sol

- Ilhas no Espaço

- Ferradura - Rio

Ilsa Leal Ferreira

* Folhagem I

Izar do Amaral Berlinck

* Inverno

Keniche Kaneco

- Evolução

- Evolução A

- Evolução B

Marília G. Saboya de Albuquerque

- Sem Título (A) 
Massuo Nakakubo

* Serigrafia I

- Serigrafia A

- Serigrafia G1

Romildo Paiva

- Condicionamento A

- Condicionamento B

* Condicionamento C

Vania Pereira

- Voe, planando...

- As obras assim assinaladas não constam na Coleção dos Salões de Arte Contemporânea de São Caetano do Sul

Prêmios Honoríficos (Menção Especial-Pesquisa)

Pedro Pinkalski

* Olhar I

* Olhar II

* Enigma

\section{SALA ESPECIAL}

Oswaldo Goeldi, Mestre da Xilogravura

Texto de Enock Sacramento 
FICHAS TÉCNICAS

SALÕES DE ARTE CONTEMPORÂNEA DE SÃO CAETANO DO SUL

IX SALÃO DE ARTE CONTEMPORÂNEA DE SÃO CAETANO DO SUL

REALIZAÇÃO:

Prefeitura Municipal de São Caetano do Sul

Departamento de Educação e Cultura

Fundação das Artes

Administração $\mathrm{H}$. Walter Braido

LOCAL: Fundação das Artes - Rua Visconde de Inhaúma, 730 - Vila Gerte

DATA: 30 de julho a 27 de agosto de 1976

\section{CAPA DO CATÁLOGO:}

Manuel Reis

\section{COMISSÃO ORGANIZADORA / EXECUTIVA:}

João José Dario (presidente)

Carlos Von Schimidt

Milton Andrade

\section{COMISSÃO DE INDICAÇÕES:}

Aracy Abreu Amaral

Artistas indicados:

(Antônio Dias / Arcangelo lanelli / Cildo Meirelles / Evandro Carlos Jardim / Gregório Correia / Mario Ishikawa / Regina Siveira / Tomoshigue Kusuno / Waltércio Caldas)

Carlos von Schimidt

Artistas indicados:

(Evandro Carlos Jardim / Gregório Gruber / Gretta Grzywacz / Humberto Spinola / Irene Buarque / Ivald Granato / Ubirajara Ribeiro / Regina Vater / Rubens Gerchman / Wesley Duke Lee)

Maria Eugenia Franco

Artistas indicados: 
(Adão Pinheiro / Antônio Carlos Rodrigues - Tuneu / Cláudio Tozzi / Edo Rocha / Evandro Carlos Jardim / Fábio Magalhães / José Rezende / Maria Helena Chartuni / Mirian Chiaverini / Tomoshigue Kusuno)

Olívio Tavares de Araújo

Artistas indicados:

(Antônio Carlos Rodrigues - Tuneu / Carlos Eduardo Zimmermmann / Claudio Tozzi / Evandro Carlos Jardim / Fábio Magalhães / Farnese de Andrade / Inácio Rodrigues / Paulo Roberto Leal / Vilma Pasqualini / Wilson Alves)

Pietro Maria Bardi

Artistas indicados:

(Alicia Rossi / Carlos Blank / Décio Ambrósio / Evandro Carlos Jardim / Fábio Magalhães / Francisco Cuoco / Maria Helena Chartuni / Philip Hallawell / Renato Brunello / Tito de Alencar)

Obs, Em negrito, artistas indicados por mais de um dos membros do júri.

\section{RELAÇÃO DOS PRÊMIOS:}

\section{Prêmio-Aquisição}

$\mathrm{Cr} \$ 35.000,00$ (prêmios correspondentes ao valor da obra declarado pelo artista)

\section{RELAÇÃO DE ARTISTAS PREMIADOS:}

Claudio Tozzi

- Dissociação das Cores

Décio Duarte Ambrósio

* Proposta D. A. 2

Evandro C. Jardim

- Madrugada

* O Coração de Máquina Frangente

* À Tarde a Sombra

* O Sol sobre a cadeira

\section{Gregório Gruber}

- Obra no 1

- Obra no 2

- Obra no 3

- Obra no 4 
Paulo Roberto Leal

- Entretela I

Rubens Gerschman

- A Televisão

- Man Woman

* As obras assim assinaladas não constam na Coleção dos Salões de Arte Contemporânea de São Caetano do Sul 
FICHAS TÉCNICAS

SALÕES DE ARTE CONTEMPORÂNEA DE SÃO CAETANO DO SUL

\section{SALÃO DE ARTE CONTEMPORÂNEA DE SÃO CAETANO DO SUL}

\section{REALIZAÇÃO:}

Prefeitura Municipal de São Caetano do Sul

Departamento de Educação e Cultura

Fundação das Artes

Administração Raimundo da Cunha Leite

LOCAL: Fundação das Artes - Rua Visconde de Inhaúma, 730 - Vila Gerte

DATA: 27 de julho a 12 de agosto de 1979

\section{CAPA DO CATÁLOGO:}

Manuel Reis

\section{COMISSÃO ORGANIZADORA / EXECUTIVA:}

Vicente Bastos (presidente)

Milton Andrade

Ulysses Cruz

Albertina P.S. Baroni

Manuel Reis

\section{COMISSÃO DE SELEÇÃO E PREMIAÇÃO:}

Casemiro Xavier de Mendonça (presidente)

Alberto Beuttenmüller

Fernando Cerqueira Lemos

Jacob Klintowitz

Paulo Klein

\section{RELAÇÃO DOS PRÊMIOS:}

\section{Prêmio-Aquisição}

Não temos informações sobre a premiação estipulada. Somente sabemos que foi pago o valor de $\operatorname{Cr} \$ 70.200,00$ em prêmios-aquisição. 
Prêmios Honoríficos (Menção Honrosa)

\section{RELAÇÃO DE ARTISTAS PREMIADOS:}

Dora Cesar Monteiro

- Compasso

Hélio Vinci

- Re/Nato

- Labirinto

- Sem Título

Hironobu Kai

- As Duas Faces II

Lucio Yutaka Kume

- Série Achados \& Perdidos 2

Luiz Guimarães (Destaque)

- Série Torturados e Torturadores

- Os Casos Complicados

Maty Vitart (Destaque)

- Ícaro numa Versão Contemporânea

- Ícaro numa Versão Contemporânea

Odair Magalhães

- Solares

Roberto Okumura

- Sem Título 2

Sérgio de Moraes

- Casa de Amigo

Sérgio Nicultcheff

- Vida

Silvio Dworecki

- Terra e Ar: Nosso Céu tem mais Estrelas

\section{Prêmios Honoríficos (Menção Honrosa)}

Arte Errar: Alice Reiko Haga / Maria Oneida Cescato / Mari Kanegae

* Embalarte

* Embalarte

* Embalarte 
Renato Brancatelli

* O Livro dos Danados I

* O Livro dos Danados II

* O Livro dos Danados III

As obras assim assinaladas não constam na Coleção dos Salões de Arte Contemporânea de São Caetano do Sul 
FICHAS TÉCNICAS

SALÕES DE ARTE CONTEMPORÂNEA DE SÃO CAETANO DO SUL

\section{SALÃO DE ARTE CONTEMPORÂNEA DE SÃO CAETANO DO SUL}

\section{REALIZAÇÃO:}

Prefeitura Municipal de São Caetano do Sul

Departamento de Educação, Cultura, Esporte e Turimo

Fundação das Artes

Administração H. Walter Braido

LOCAL: Fundação das Artes - Rua Visconde de Inhaúma, 730 - Vila Gerte

DATA: 30 de setembro a 30 de outubro de 1988

\section{CAPA DO CATÁLOGO:}

\section{COMISSÃO ORGANIZADORA / EXECUTIVA:}

Dulce Junquetti (presidente)

Fausto Polesi - diretor de redação do Diário do Grande ABC

Claudio Musumeci - vereador

João José Dario

Aleksandar Jovanovic - Assessor de Comunicação Social

Helena Petronilho - Assessora de Cultura DEPECET

Valdenizio Petrolli - Chefe setor de imprensa

Claudinei Rufini - Animador Cultural SESC - São Caetano

\section{COMISSÃO DE SELEÇÃO E PREMIAÇÃO:}

Miller de Paiva da Silva

Enock Sacramento

José Carlos Porangaba Martins

\section{RELAÇÃO DOS PRÊMIOS:}

Prêmio-Aquisição

Cz\$ 350.000,00 
Prêmios Honoríficos (Menção Especial do Júri)

\section{RELAÇÃO DE ARTISTAS PREMIADOS:}

Flávio Antônio Abuhab (Flávio Abuhab)

- Sem Título

João Fábio Moskas (João Moskas)

- Paisagem com Trem

- Soltando Balão

- O Destino levou o meu amor

Numa Leme Junior (Numa)

* Graffit City

Valdir Gomez (Gomez)

* Sem Título

José Garibaldi Paças de Lima (Garibaldi)

- Weladhara

- Azul e Terra

* As obras assim assinaladas não constam na Coleção dos Salões de Arte Contemporânea de São Caetano do Sul

\section{Prêmios Honoríficos (Menção Especial do Júri)}

Domingos Chirinéa (Chirinéa)

* Arca de Noé

* Releitura da Arte Rupestre Convergência

* Releitura da Arte Rupestre Fúria de Bisontes 
ANEXO E

PARTICIPANTES DAS COMISSÕES DE SELEÇÃO E JULGAMENTO / PREMIAÇÃO

\begin{tabular}{|c|c|}
\hline Jurado & Salão \\
\hline Alberto Aliberti & $\mathrm{I} / \mathrm{II} / \mathrm{III}$ \\
\hline Alberto Beuttenmüller & $x$ \\
\hline Aracy Abreu Amaral & IX \\
\hline Arcangelo lanelli & IV \\
\hline Arnaldo Ferrari & $\mathrm{I}$ \\
\hline Carlos Alberto Fajardo & $\mathrm{V}$ \\
\hline Carlos von Schimidt & IX \\
\hline Casemiro Xavier de Mendonça & $x$ \\
\hline Enock Fernandes Sacramento & III / IV / V / VI / VII / VIII / XI \\
\hline Fernando Cerqueira Lemos & $x$ \\
\hline Hermelindo Fiaminghi & II / III / IV / V \\
\hline Ivo Zanini & VI / VII \\
\hline Jacob Klintowitz & $x$ \\
\hline Jacques Douchez & $\mathrm{V}$ \\
\hline João José Dario & VI \\
\hline José Armando Pereira da Silva & IV / V / VII \\
\hline José Carlos Porangaba Martins & $\mathrm{XI}$ \\
\hline José Geraldo Vieira & $\mathrm{I} / \mathrm{II}$ \\
\hline Joseph M. Luyten & VII \\
\hline Lisetta Levi & $\mathrm{VI} / \mathrm{VII} / \mathrm{VIII}$ \\
\hline Maria Eugenia Franco & IX \\
\hline Mario Schemberg & $1 / 11$ \\
\hline Maurício Nogueira Lima & III / IV \\
\hline Miller de Paiva da Silva & $\mathrm{XI}$ \\
\hline Milton Andrade & VIII \\
\hline Olívio Tavares de Araújo & IX \\
\hline Olney Krüse & VIII \\
\hline Paulo Klein & $x$ \\
\hline
\end{tabular}




\begin{tabular}{|c|c|}
\hline Pietro Maria Bardi & IX \\
\hline Romeu de Graça & VI \\
\hline Sinval Correia Soares & II / III \\
\hline Walter Levy & I \\
\hline Wolfgang Pfeiffer & VIII \\
\hline
\end{tabular}




\section{ANEXO F \\ ARTISTAS PARTICIPANTES DOS \\ SALÕES DE ARTE CONTEMPORÂNEA DE SÃO CAETANO DO SUL}

\begin{tabular}{|c|c|}
\hline \multicolumn{2}{|l|}{ I SALÃO } \\
\hline 1. Alba Regina Dias de Souza & 2. Aldir Mendes de Souza \\
\hline 3. Alfredo Savii & 4. Alice Brill \\
\hline 5. Aluísio Domingos dos Santos & 6. Ana Russo Morrone \\
\hline 7. $\quad$ Ângelo Volpicelli & 8. Antônio Carelli \\
\hline 9. Antônio Vitor & 10. Armando M. Sendin \\
\hline 11. Bráulio Victor Reis Esteves & 12. C. Alberto Paudalho \\
\hline 13. Celia Beatriz Guimarães Monte & 14. Colette Pujol \\
\hline 15. Danilo Polidoro & 16. Delson Pedroso \\
\hline 17. Duilio Juliel Galli & 18. Edison Cruz \\
\hline 19. Eduardo I. Rodrigues & 20. Eisaburo Mori \\
\hline 21. Eunibaldo Tinôco de Souza & 22. Flávia Lúcia Arrigucci \\
\hline 23. Francisco Liberato de Mattos & 24. Gabriele Leozzi \\
\hline 25. Gastone Rinaldi & 26. Gioconda D'arace Ferreira \\
\hline 27. Hannelore Jacobowityz & 28. Hans Schadler \\
\hline 29. Hans Suliman Grudzinski & 30. Heinz Kühn \\
\hline 31. Hermelindo Fiaminghi & 32. Hisao Shirai \\
\hline 33. Hissao Sakakibara & 34. Isaura b. Batista \\
\hline 35. Jacobo & 36. Jandyra Waters \\
\hline 37. Jayme Xandó Cunha & 38. João Delijaicovb Filho \\
\hline 39. João Ferreira & 40. João José Dario \\
\hline 41. João Jurandir Spinelli & 42. João Suzuki \\
\hline 43. Joaquim Ferreira Esteves & 44. José Brasiliense \\
\hline 45. José Francisco Arina Inarra & 46. José Luís Moraes Simonetti \\
\hline 47. Juan Ramon Capote Moreno & 48. Judith Lauand \\
\hline 49. Kenichi Kaneco & 50. Kurt Hollander \\
\hline 51. Leila Regina Porto de Andrade & 52. Leopoldo Raimo \\
\hline 53. Lothar-Charoux & 54. Lourdes Cedran \\
\hline 55. Lucilia de Toledo Mezzótero & 56. Luiz Aparecido Barelli \\
\hline 57. Luiz Hamen & 58. Lydia Okumura \\
\hline 59. Mari Yoshimoto & 60. Maria do Carmo Gomes Lorenzini \\
\hline
\end{tabular}




\begin{tabular}{|l|l|}
\hline 61. Maria Glória Almeida Siqueira & 62. Marina Salerno Raimo \\
\hline 63. Mariselda Brumajny & 64. Massuo Nakakubo \\
\hline 65. Nelson Alquezare Román & 66. Nibio Gandioli \\
\hline 67. Niobe Xandó & 68. Paulo Chaves \\
\hline 69. Paulo Mentem & 70. Pavel Kudis \\
\hline 71. Pedro Alvares Cabral Campos & 72. Pedro Birkenstein \\
\hline 73. Renato Wagner & 74. Roberto Pires \\
\hline 75. Romilda Louzada & 76. Rosa Shiroma Bersani \\
\hline 77. Rubem Rey & 78. Sergio Pastura \\
\hline 79. Sulita Di Franco & 80. Suzana Kutiyel \\
\hline 81. Tecla Ivanova & 82. Ubirajara Molina Ribeiro \\
\hline 83. Umberto Sperandio & 84. Vera Moreira Mazzieri \\
\hline 85. Vinício Pradella & 86. Wakichi Yamamoto \\
\hline 87. Zbigniew Capioni & \\
\hline
\end{tabular}

\section{SALÃO}

\begin{tabular}{|l|l|}
\hline 1. Aldir Mendes de Souza & 2. Alex Vallauri \\
\hline 3. Alfredo Savii & 4. Aluísio Domingos dos Santos \\
\hline 5. Ângelo Volpicelli & 6. Anna Russo Morrone \\
\hline 7. Antônio Henrique A. Amaral & 8. Antônio Marins Filho \\
\hline 9. Antônio Vitor & 10. Armando M. Sendin \\
\hline 11. Arnaldo Celebrone & 12. Barbara Schubert Spanoudis \\
\hline 13. Beatriz Rota-Rossi & 14. Carlos A. de Souza Pereira - Duto \\
\hline 15. Carlos da Silva Calçada & 16. Carlos Simal Yegue \\
\hline 17. Cassiano Pereira Nunes & 18. Charlotta Adlerová \\
\hline 19. Circe Bernardes de Andrade & 20. Claudio Feldman \\
\hline 21. Claudio Tozzi & 22. Clodomiro Lucas \\
\hline 23. Danilo Polydoro & 24. Décio Noviello \\
\hline 25. Delson Pedroso & 26. Duilio Juliel Galli \\
\hline 27. Eisaburo Mori & 28. Elber A. Duarte \\
\hline 29. Emilia Ceccarelli & 30. Ernestina Karman \\
\hline 31. Eunibaldo Tinoco de Souza & 32. Eurico Luis dos Santos \\
\hline 33. Flávia Lúcia Fagundes Arrigucci & 34. Gastone Rinaldi \\
\hline 35. Geraldo Moreno & 36. Geraldo Rocha \\
\hline 37. Gilberto O. Salvador & 38. Gilson Ramos Barbosa \\
\hline
\end{tabular}




\begin{tabular}{|c|c|}
\hline 39. Gioconda Campos Ferreira & 40. Gloria de Almeida \\
\hline 41. Haile Bergamasco Castiglioni & 42. Hannelore Jacobo Witz \\
\hline 43. Hélcio Deslandes & 44. Helena B. Caminha \\
\hline 45. Heloisa Selmi Dei Meinberg & 46. Henrique Lorenzini Filho \\
\hline 47. Henrique S. Vasconcelos Filho & 48. Hudla Perla Pintchovski \\
\hline 49. Humberto A. Miranda Espíndola & 50. Humberto Velame Miranda \\
\hline 51. Irma Neumann & 52. Jacobo \\
\hline 53. Jandyra Waters & 54. Joal de Castro Reis \\
\hline 55. João B. F. de Oliveira - Ferrazon & 56. João José Dario \\
\hline 57. João Osório Bueno Brzezinski & 58. João Parisi Filho \\
\hline 59. João Sartori & 60. Joaquim Ferreira Esteves \\
\hline 61. Joel de Godoy & 62. Joel Xavier \\
\hline 63. Jorge Fránulio & 64. José Alberto Teixeira Vaz \\
\hline 65. José Brasiliense & 66. José Edgar Cordeiro de Souza \\
\hline 67. José Roberto Pereira Cassiano & 68. Judith Lauand \\
\hline 69. Kenichi Kaneko & 70. Kurt Hollander \\
\hline 71. Léa Ester Colombo & 72. Leila Porto de Andrade \\
\hline 73. Lothar Charoux & 74. Luciano Morosi \\
\hline 75. Lucilia De Toledo Mezzotero & 76. Lúcio Moreira \\
\hline 77. Luiz Alberto Barbieri & 78. Luiz Aparecido Barelli \\
\hline 79. Luiz Hamen & 80. Madeloine Roux \\
\hline 81. Manuel Álvaro Queiroz da Silva & 82. Manuel de M. Vinagre - Bandarra \\
\hline 83. Marcelo Bottas Martinez & 84. Maria Angiel \\
\hline 85. Maria Clarice de Freitas Lins & 86. Maria do Carmo Gomes Lorenzini \\
\hline 87. Maria Ester Benites & 88. Maria Helena Penteado \\
\hline 89. Maria Helena Ramos de Souza & 90. Maria Luiza Xavier \\
\hline 91. Maria Reif & 92. Marília Campanário \\
\hline 93. Mario de Freitas & 94. Mario Luiz Paulucci \\
\hline 95. Mariselda Bumajny & 96. Mauro Bondi \\
\hline 97. Messias E. Carvalho & 98. Michiko Komatsu \\
\hline 99. Milton Misson & 100. Minoru Takatori \\
\hline 101. Mona Gorovitz & 102. Myrtha Rosato \\
\hline 103. Nelson Godoy Costa & 104. Nibio Gandioli \\
\hline 105. Nicola D'amico & 106. Olinda Tasquim \\
\hline 107. Orlando Retroz & 108. Paulo Becker \\
\hline
\end{tabular}




\begin{tabular}{|cl|cl|}
\hline 109. & Paulo De Andrade & 110. & Paulo Mentem \\
\hline 111. & Pavel Kudis & 112. & Pedro Alvares Cabral Campos \\
\hline 113. & Pedro Sérgio Dória Chaves & 114. & Pier Luisi \\
\hline 115. & Rajá Simon & 116. & Regis Machado Silva \\
\hline 117. & René Martial & 118. & Ricardo Ribemboim \\
\hline 119. & Roberto Pires & 120. & Roberto Souto Maior Lins \\
\hline 121. & Rubem Rey & 122. & Rubens José M. Cunha Lima \\
\hline 123. & Rubens Mamar & 124. & Sulita de Franco \\
\hline 125. & Susana Kutiyel & 126. & Thereza Miranda Alves \\
\hline 127. & Tieko Homma & 128. & Tomoko Harada \\
\hline 129. & Ubirajara M. L. Ribeiro & 130. & Valdeir Oliveira Maciel \\
\hline 131. & Vera Ilce & 132. & Vicente Di Franco \\
\hline 133. & Victor Decio Gerhard & 134. & Vinicius Pradella \\
\hline 135. & Vladimir Sopata Rodrigues & 136. & Yasuichi Kojima \\
\hline 137. & Zelda Blinder Fischer & & \\
\hline
\end{tabular}

\section{SALÃO}

\begin{tabular}{|l|l|}
\hline 1. Aderbal Silva Moura & 2. Aldir Mendes de Souza \\
\hline 3. Alicia G. Rossi & 4. Aluísio Domingos dos Santos \\
\hline 5. Anahid Chahinian & 6. Antônio Carlos de A. Mattos -Dé \\
\hline 7. Antônio Lucio Santos & 8. Antônio Vitor \\
\hline 9. Armando M. Sendin & 10. Barretto Jr. \\
\hline 11. Boris Arrivabene & 12. Carlos Alberto Paudalho \\
\hline 13. Carlos Schuster & 14. Cassiano Pereira Nunes \\
\hline 15. Celso Arcângelo & 16. Cláudio Tozzi \\
\hline 17. Clelia Cotrim & 18. Dalton Salem Asseff \\
\hline 19. Dino Ippolito & 20. Djanira Maria Da Conceição Volpi \\
\hline 21. Eduardo Iglesias & 22. Eduardo J. Rodrigues \\
\hline 23. Eisaburo Mori & 24. Eliane Borges \\
\hline 25. Esteves & 26. Eunibaldo Tinoco De Souza \\
\hline 27. Fernando da Silva Deamo & 28. Francisca Carolina do Val \\
\hline 29. Francisco Pereira de Faria & 30. Gilberto Gibrail \\
\hline 31. Hanna Henriette Brandt & 32. Hannelore Jacobowitz \\
\hline 33. Hans Schadler & 34. Heinz Kühn \\
\hline 35. Hendrik Antonius Reydon & 36. Henrique Pait \\
\hline
\end{tabular}




\begin{tabular}{|l|l|}
\hline 37. Henrique Riga & 38. Hudla Perla Pintchovski \\
\hline 39. Iracy de Almeida Puccini & 40. Iracy Nitsche \\
\hline 41. Irma Neumann & 42. Irmgard Longman \\
\hline $\begin{array}{l}\text { 43. Israel Sancovski e Jerônimo Bonilha } \\
\text { Esteves }\end{array}$ & 44. João Osório Brzezinski \\
\hline 45. José Alberto Teixeira Vaz & 46. José Belchior da Fonseca \\
\hline 47. José Carlos dos Santos & 48. José Fagundes Altenfelder Silva \\
\hline 49. Juarez Magno de Freitas Almeida & 50. Katsutoshi Mori \\
\hline 51. Leila Porto De Andrade & 52. Lília A. Pereira da Silva \\
\hline 53. Lothar Charoux & 54. Lourdes Cedran \\
\hline 55. Luiz Barelli & 56. Luiz Wade Piccinini \\
\hline 57. Manuel Alvaro Queiroz da Silva & 58. Márgara das Graças P. Amaral \\
\hline 59. Maria Auxiliadora da Silva & 60. Maria do Carmo Gomes Lorenzini \\
\hline 61. Mariana Reif & 62. Mariselda Bumajny \\
\hline 63. Marlene Crespo Fuser & 64. Messias E. Carvalho \\
\hline 65. Moisés Felipe Lalinde Acereda & 66. Nibio Gandioli \\
\hline 67. Nisete Sampaio & 68. Orlando Retroz \\
\hline 69. Oscar de Almeida Netto & 70. Paulo Menten \\
\hline 71. Pavel Kudis & 72. Pedro Moacyr de Campos Jr. \\
\hline 73. Régis Machado Silva & 74. Renato Wagner \\
\hline 75. Ricardo Gatti & 76. Ricardo Ribenboim \\
\hline 77. Rubem Rey & 78. Ruben Mam (Rubens Mamar) \\
\hline 79. Salvador & 80. Sara Arenzon Altman \\
\hline 81. Sepp Baendereck & 82. Sergius Erdelyi \\
\hline 83. Tetsushiro Sussuta & 84. Tiêko Homma \\
\hline 85. Tio Hok Tjay & 86. Tomoko Harada \\
\hline 87. Ulieno Sergio Cicci & 88. Vera Ilse \\
\hline 89. Vicente di Franco Filho & 90. Walther Lopes Pinheiro \\
\hline 91. Yukio Suzuki & \\
\hline
\end{tabular}

\section{SALÃO}

1. Adélia Fingermann

3. Alfredo Elgud Samad

5. Aracy R. Monteiro Zanotti
2. Aldir Mendes de Souza

4. Antônio Vitor da Silva

6. Bernardo Antunes 


\begin{tabular}{|l|l|}
\hline 7. Bernardo Caro & 8. Bethy B. Monteiro Giudice \\
\hline 9. Cassiano Pereira Nunes & 10. Celia Igel \\
\hline 11. Cláudio Feldman & 12. Cláudio Tozzi \\
\hline 13. Clélia Cotrim & 14. Duilio Jules Galli \\
\hline 15. Eduardo Iglesias & 16. Emi Mori \\
\hline 17. Emilia Cecarelli & 18. Estevão Nador \\
\hline 19. Eveline Borges & 20. Fernando Deamo \\
\hline 21. Gabriel Borba Filho & 22. Gabriel Borba Filho \\
\hline 23. Hannah Henriette Brandt & 24. Helena Caminha \\
\hline 25. Iracy de Almeida Puccini & 26. Irene Satie Shoyama \\
\hline 27. Irma Newman & 28. Irmgard Longman \\
\hline 29. Isabel Santos Toledo & 30. Israel Sancovski e Jerônimo Bonilha \\
\hline 31. Jayme Xandó Cunha & \multicolumn{1}{c|}{ Esteves } \\
\hline 33. Katsutoshi Mori - Kam & 32. Joaquim Gimenes Salas \\
\hline 35. Lothar Charoux & 34. Leopoldo Raimo \\
\hline 37. Maria Luiza Gusman & 36. Luiz Aparecido Barelli \\
\hline 39. Massuo Nakakubo & 38. Maria Olímpia Vassão \\
\hline 41. Mina Schwartz & 40. Mauro Morini \\
\hline 43. Nicola D'Amico & 42. Nely Pedroso Toledo \\
\hline 45. Norberto Stori & 44. Niobe Xandó \\
\hline 47. Oswaldo Martins Toledo & 46. Orlando Retroz \\
\hline 49. Pavel Kudis & 48. Paulo Chaves \\
\hline 51. Pupet Weckx & 50. Pedro Tort \\
\hline 53. Regis Machado Silva & 52. Raphael Da Costa \\
\hline 55. Romildo Paiva & 54. Reynaldo Bianchi Netto \\
\hline 57. Sérgio Fingermann & 56. Rosa Vieira \\
\hline 59. Sonia Von Brusky & 58. Sinval Correia Soares \\
\hline 61. Tetsuo Nomura & 60. Sylvia Landsberger \\
\hline 63. Vera Ilse Cruz & 62. Vânia Pereira \\
\hline 65. Wally Selma Baendereck & 64. Vicente de Franco Filho \\
\hline & \\
\hline
\end{tabular}




\begin{tabular}{|c|c|}
\hline \multicolumn{2}{|l|}{ V SALÃO } \\
\hline 1. Aderbal Moura & 2. Aldir Mendes de Souza \\
\hline 3. Aluísio & 4. Antonio Carlos Rodrigues - Tuneu \\
\hline 5. Antonio Lizárraga & 6. Antonio Vitor \\
\hline 7. Aracy R. M. Zanotti & 8. Ary Luiz Bom \\
\hline 9. Ary do Carmo Mari & 10. Aurea Zila Antunes Pires de Almeida \\
\hline 11. Bernardo Antunes & 12. Bethy Bowen Monteiro Giudice \\
\hline 13. Carlos Calçada & 14. Carlos Enrique M. de Lacerda \\
\hline 15. Carlos Lemos & 16. Clarisse Gueller - Glê \\
\hline 17. Cleusa Maria Dall'antonia & 18. Danielle Gyger-Guggenheim \\
\hline 19. Décio Duarte Ambrósio & 20. Delvo Paiva - Vico \\
\hline 21. Diana Soares - Nadia & 22. Dora \\
\hline 23. Elgud Samad & 24. Eliane Borges \\
\hline 25. Elisabeth Etzel & 26. Etelvina da Silva - "Tel" \\
\hline 27. Eunibaldo Tinôco de Souza & 28. Geraldo José de Souza - "Geu" \\
\hline 29. Gerty Sarué & 30. Gilberto Pereira \\
\hline 31. Glauco Francisco Adriano de Broi & 32. Glória de Almeida \\
\hline $\begin{array}{l}\text { 33. Grupentres (Henry Vitor Santos, Luis } \\
\text { Antônio Telles e Rogério F. Duarte) }\end{array}$ & 34. Hannah Brandt \\
\hline 35. Hans Suliman Grudzinski & 36. Henry Vitor Santos \\
\hline 37. Iracy de Almeida Puccini & 38. Irene Satie Shoyama \\
\hline 39. Isabel de Jesus & 40. Isabel Santos Toledo \\
\hline 41. Jaime Batista Paiva & 42. Jaime Xandó Cunha \\
\hline 43. Luci Yamashiro & 44. Luís Antônio Telles \\
\hline 45. Luiz Amatuzzi & 46. Luiza Irene G. Galvão \\
\hline 47. Luiz Carlos Daher & 48. Luiz Carlos Rueckert Parreiras \\
\hline 49. Maria Auxiliadora da Silva & 50. Mariana Reif \\
\hline 51. Marília Augusta de Carvalho Franco & 52. Mario Premazzi Jr. \\
\hline 53. Myrna Freitas Corrêa & 54. Nelson Domingos Bavaresco \\
\hline 55. Nely Toledo & 56. Norberto Stori \\
\hline 57. Orlando Retroz & 58. Oswaldo Martins Toledo \\
\hline 59. Onéas Arantes & 60. Paulo Menten \\
\hline 61. Regis Machado Silva & 62. Reynaldo Bianchi Netto \\
\hline 63. Ricardo Bresaola & 64. Robespierre Sentelhas \\
\hline 65. Romildo Paiva & 66. Ronaldo Bertaco \\
\hline
\end{tabular}




\begin{tabular}{|l|l|}
\hline 67. Rubens Vaz lanelli & 68. Rudy Karter \\
\hline 69. Sirpa Malin (Nupa) & 70. Suzana Dulce Fagundes Lima \\
\hline 71. Sylvia Schlossinger & 72. Úrsula Hamburguer \\
\hline 73. Wanderley Antônio Braga Bezzi & \\
\hline
\end{tabular}

\begin{tabular}{|l|l|}
\hline VI SALÃo & \multicolumn{2}{l|}{ 2. Auresnede Pires Stephan } \\
\hline 1. Aracy R. Monteiro Zanotti & 4. Benedito Centofani Prado \\
\hline 3. Belemin Luiz Gomes & 6. Carlos Enrique M. de Lacerda \\
\hline 5. Bernardo Cid & 8. Cesar Romero \\
\hline 7. Carmo Vaz & 10. Cleber Bonetti Machado \\
\hline 9. Cesar Oscar A. Pellegrino & 12. Duilio Galli \\
\hline 11. Danielle Gyger - Guggenheim & 14. Elisaura Motta Fernandes Sacramento \\
\hline 13. Eliane M. Borges & 16. Eros Oggi \\
\hline 15. Ermelindo Nardin & 18. Felisberto Sá de Oliveira Filho \\
\hline 17. Eva Furnari & 20. Francisco das Neves de Andrade \\
\hline 19. Francisco M. D. Leão & 22. Geraldo José dos Santos - Géu \\
\hline 21. Gerty Sarué & 24. João Pirahy \\
\hline 23. Hannah Henriette Brandt & 26. Lucília de Toledo Mezzótero \\
\hline 25. Lenice Raci Abdulmassih & 28. Luiza M. Grzeidak \\
\hline 27. Luiz Hamen & 30. Marcos Concilio \\
\hline 29. Lya Amaral Souza & 32. Maria Tomaselli Cirne Lima \\
\hline 31. Maria Tereza Rimoli de Graça & 34. Mario Premazzi Junior \\
\hline 33. Mario Marcos Tagnini & 36. Meiri Levin \\
\hline 35. Mariselda Bumajny & 38. Norberto Stori \\
\hline 37. Nely Toledo & 40. Paulo Houayek \\
\hline 39. Odila Mestriner & 42. Pedro Lopes Soares \\
\hline 41. Paulo Portella Filho & 44. Regis Machado da Silva \\
\hline 43. Rachel Salém & 46. Romeu de Graça \\
\hline 45. Romão Bertoncel & 48. Senir Lourenço Fernandez \\
\hline 47. Rubens lanelli & 50. Sérgio Maudo \\
\hline 49. Sérgio Bezerra Pinheiro & 52. Sonia Maria Tosatti da Rosa \\
\hline 51. Sinval Correia Soares & 54. Thereza Magalhães Borges \\
\hline 53. Tai Hsuan-Na & 56. Vania Pereira \\
\hline 55. Vanda Alves Ferreira & \\
\hline
\end{tabular}




\begin{tabular}{|l|l|}
\hline 57. Vicente Gil Filho & 58. Vilmar Douglas Hoepers \\
\hline 59. Yasuo Nakamura & 60. Yui Kraus \\
\hline
\end{tabular}

\begin{tabular}{|l|l|}
\hline \multicolumn{2}{|l|}{ VII SALÃo } \\
\hline 1. Aderson Medeiros & 2. Alfredo Ugarte Del Castillo \\
\hline 3. Alegre Sarfaty Grzywacz & 4. Antonio Bontempo \\
\hline 5. Antonio Brunoro Netto & 6. Antonio Carlos Rampazzo \\
\hline 7. Antonio Celso Saparapan & 8. Antonio Hudson Buck de Carvalho \\
\hline 9. Antonio Vitor & 10. Arthur Francisco Baptista \\
\hline 11. Aracy R. M. Zanotti & 12. Bal Moura \\
\hline 13. Cacilda F. F. de mattos & 14. Celso Rogerio Berton \\
\hline 15. César Romero & 16. Charbel Hanna El Ottra \\
\hline 17. Cledson Jaider de Resende & 18. Claudio Gillberto Ely \\
\hline 19. Cleópatra V. Tschebutschenko (cleo) & 20. E. M. Abellá \\
\hline 21. Edith Terezinha Neves & 22. Eduardo Fontes Hotz \\
\hline 23. Eduardo Iglesias & 24. Elias Luiz da Silva \\
\hline 25. Elvio Alvarez Santiago & 26. Emilia Okubo \\
\hline 27. Emiko Mori & 28. Ermelindo Nardin \\
\hline 29. Francisco Biojone & 30. Gervindo Ferreira Ramos \\
\hline 31. Giba Ilhabela & 32. Gimenez \\
\hline 33. Glória Blenner Jacob & 34. Habuba Farah Ricetti \\
\hline 35. Hudla Perla Pintchovski Ventura & 36. Ilsa Leal Ferreira \\
\hline 37. Ismael Assumpção & 38. Itsuo Kubo \\
\hline 39. J. Gimenes Salas & 40. J. Rissin \\
\hline 41. Jacobo - Catalão & 42. Jair Glass \\
\hline 43. João Batista Santos & 44. João K. Suzuki \\
\hline 45. João Parisi Filho & 46. José Conceição Grilo de Carvalho \\
\hline 47. José Luiz de Queiroz Teles & 48. José Pestaña \\
\hline 49. José Roberto Cardoso Ferreira & 50. José Teixeira \\
\hline 51. Lucília de Toledo Mezzótero & 52. Lucio Galvão \\
\hline 53. Lucio Yutaka Kume & 54. Luis Carlos Ferracioli \\
\hline 55. Luiza Morbini Grzeidak & 56. Lya Amaral Souza \\
\hline 57. Manfredo Souza Neto & 58. Maria Aparecida de Moura \\
\hline 59. Maria Lucia Costa Porto & 60. Mariselda Bumajny \\
\hline 61. Marycha Angiel & 62. Max Sursol \\
\hline
\end{tabular}




\begin{tabular}{|l|l|}
\hline 63. Meiri Levin & 64. Michéle Annie Bril \\
\hline 65. Milton Precivale & 66. Nair Kremer \\
\hline 67. Nely Toledo & 68. Nestor Peres \\
\hline 69. Nora Rodrigo Alves & 70. Norival B. Figueiredo \\
\hline 71. Odair Magalhães & 72. Orlando Mattos \\
\hline 73. Ovídio Almeida Corrêa & 74. Pedrinho Gimenez \\
\hline 75. Pedro Soares Fogaça Filho & 76. Pier Luigi Canepa \\
\hline 77. Regis Machado Silva & 78. Renate Heiberg \\
\hline 79. Romão Bertoncel & 80. Romildo Paiva \\
\hline 81. Ronaldo da Silva Rego & 82. Ronaldo Bertaco \\
\hline 83. Rosa Maria Cabral Trindade Barreto & 84. Selma Seva \\
\hline 85. Sergio Bezerra Pinheiro & 86. Sinval Correia Soares \\
\hline 87. Vandice (André Masini) & 88. Vania Cercal Assumpção \\
\hline 89. Vania Pereira & 90. Vera Alves de Oliveira \\
\hline 91. Virgilio Alves Borges de Andrade & 92. Wilson Rodrigues de Moraes \\
\hline 93. Yole Paterniani Travassos & \\
\hline
\end{tabular}

\begin{tabular}{|l|l|}
\hline \multicolumn{2}{|l|}{ VIII SALÃo } \\
\hline 1. Ana Alice Francisquetti & 2. Anna Maria Barros de Vecchi \\
\hline 3. Antenor Lago Costa & $4 . \quad$ Antônio N. Silva \\
\hline 5. Antonio Signo Pereira de Souza & 6. Antonio Vitor \\
\hline 7. Auresnede Pires Stephan & 8. Cacilda f. de mattos \\
\hline 9. Cezira Carpanezzi & 10. Cláudio Tozzi \\
\hline 11. Décio Lima Deck & 12. Décio Soncini Júnior \\
\hline 13. Duilio Galli & 14. Edgard B. Fonseca filho \\
\hline 15. Elenir de Oliveira Teixeira & 16. Eliana Anghimah \\
\hline 17. Gretta & 18. Hanna Henriette Brandt \\
\hline 19. Hans S. Grudzinski & 20. Hermes de Magalhães \\
\hline 21. Ilsa Leal Ferreira & 22. Ivone Couto Danza \\
\hline 23. Izar Do Amaral Berlinck & 24. Joaquim Gimenes Salas \\
\hline 25. José Luiz de Queiróz Telles & 26. Josepha Plácida de Lima \\
\hline 27. Keniche Kaneco & 28. Kiyomi Nomura \\
\hline 29. Laura Carolina Altschull & 30. Lucília de Toledo Mezzótero \\
\hline 31. Maria Antonieta Amaral Souza Barros & 32. Maria Aparecida Spinola \\
\hline 33. Margot de Mattos Delgado Kardos & 34. Marília G. Saboya de Albuquerque \\
\hline
\end{tabular}




\begin{tabular}{|l|l|}
\hline 35. Mário Fiore Moreira Júnior & 36. Massuo Nakakubo \\
\hline 37. Miguel Sevilla Neto & 38. Milton Precivale \\
\hline 39. Newton Ferreira de Mesquita & 40. Nori Figueiredo \\
\hline 41. Pedro Pinkalski & 42. Pedro Soares Fogaça Filho \\
\hline 43. Percival Tirapeli & 44. Regina Helena Ferreira da Silva \\
\hline 45. Renate Heilberg & 46. Roberto Sandoval \\
\hline 47. Romildo Paiva & 48. Rosa Figueiredo de Albuquerque \\
\hline 49. Romão Bertoncel & 50. Vania Pereira \\
\hline
\end{tabular}

\begin{tabular}{|l|l|}
\hline \multicolumn{2}{|l|}{ IX SALÃo } \\
\hline 1. Adão Pinheiro & 2. Alicia G. Rossi \\
\hline 3. Antônio Carlos Rodrigues (Tuneu) & 4. Carlos Blank \\
\hline 5. Claudio Tozzi & 6. Decio Duarte Ambrósio \\
\hline 7. Evandro C. Jardim & 8. Fábio Magalhães \\
\hline 9. Francisco Carlos Paulo Cuoco & 10. Gregório Gruber \\
\hline 11. Gretta Grzywacz & 12. Inácio Rodrigues De Oliveira \\
\hline 13. Irene Buarque De Gusmão & 14. Ivald Granato Filho \\
\hline 15. Maria Helena Chartuni & 16. Paulo Roberto Leal \\
\hline 17. Philip Hallawell & 18. Regina Silveira \\
\hline 19. Regina Vater & 20. Renato Brunello \\
\hline 21. Rubens Gerschman & 22. Ubirajara Ribeiro \\
\hline 23. Wilson Alves & \\
\hline
\end{tabular}

\begin{tabular}{|l|l|}
\hline \multicolumn{2}{|l|}{ X SALÃo } \\
\hline 1. Adão Pinheiro & 2. Adevaldo Ferreira Rodrigues \\
\hline 3. Aldir Mendes de Souza & $\begin{array}{l}\text { 4. Arte Errar: Alice Reiko Haga / Maria } \\
\text { Oneida Cescato / Mari Kanegae }\end{array}$ \\
\hline 5. Ângela maria de O.L. Biondi & 6. Antonio Carlos de A. Mattos \\
\hline 7. Arnaldo R. Neves Junior & 8. Dora Cesar Monteiro \\
\hline 9. Francisco Rodrigues Coelho Jr. & 10. Hélio Vinci \\
\hline 11. Hironobu Kai & $\begin{array}{l}\text { 12. Industrial Design: Wagner Moschella/ } \\
\text { José Tibério / Manoel Barbosa }\end{array}$ \\
\hline 13. João Batista C. de Deus & 14. João J. Spinelli \\
\hline 15. John Graz & 16. José Carlos Bisconcini Gama \\
\hline 17. José Carlos Moura & 18. José Hélio Silveira Leite \\
\hline
\end{tabular}




\begin{tabular}{|l|l|}
\hline 19. José Roberto Cardoso Ferreira & 20. José Roberto Zanellato \\
\hline 21. Juan José Ojea & 22. Laércio Takanori Inaba \\
\hline 23. Luciano Amaral Rocha & 24. Lucio Yutaka Kume \\
\hline 25. Luiz Gobeth Filho & 26. Luiz Guimarães (Destaque) \\
\hline 27. Márcio Donato Périgo & 28. Margot de Mattos Delgado \\
\hline 29. Maria Christina Parisi & 30. Maria Helena Grembecki \\
\hline 31. Maria Yole U. Vanossi & 32. Maty Vitart (Destaque) \\
\hline 33. Nestor Gonçalves Oliveira Filho & 34. Nestor Peres \\
\hline 35. Odair Magalhães & 36. Osmar Buono \\
\hline 37. Renato Brancatelli & 38. Roberto Okumura \\
\hline 39. Romão Bertoncel & 40. Sérgio De Moraes \\
\hline 41. Sérgio Niculitcheff & 42. Silvio Dworecki \\
\hline 43. Vera Da Silva Prado & \\
\hline
\end{tabular}

\begin{tabular}{|c|c|}
\hline \multicolumn{2}{|l|}{ XI SALÃO } \\
\hline 1. Afonso Cláudio Zuljewic & 2. $\quad$ Aldo Abel Perez (A. Perez) \\
\hline $\begin{array}{l}\text { 3. Ana Maria Dubraz da Costa André } \\
\text { (Ana André) }\end{array}$ & 4. Anita Cassin Lorena (Anita Cassin) \\
\hline 5. $\quad$ Claudia Rodrigues (Diá Rodrigues) & $\begin{array}{l}\text { 6. Claudio Felipe Oliveira Cretti (Claudio } \\
\text { Cretti) }\end{array}$ \\
\hline 7. $\quad$ Djalma Nunes da Silva (Djalma) & 8. $\quad$ Domingos Chirinéa (Chirinéa) \\
\hline 9. Edmilson Luiz Vicente & $\begin{array}{l}\text { 10. Flavio Antônio Abuhab (Flávio } \\
\text { Abuhab) }\end{array}$ \\
\hline 11. Isa Hiray (Isa) & $\begin{array}{l}\text { 12. Jandira Chagas Martini (Jandira } \\
\text { Martini) }\end{array}$ \\
\hline 13. João Fábio Moskas (João Moskas) & 14. José Dias Munhoz \\
\hline $\begin{array}{l}\text { 15. José Garibaldi Paças de Lima } \\
\text { (Garibaldi) }\end{array}$ & $\begin{array}{l}\text { 16. José Roberto Cunha da Silva (Robert } \\
\text { Cunha) }\end{array}$ \\
\hline 17. Klaus Karall & 18. Lídia Lopes Torres (L.L. Torres) \\
\hline 19. Marcelo Mari & 20. Márcio Fidelis \\
\hline 21. Marília Vieira Costa (Marília) & $\begin{array}{l}\text { 22. Miriam Meire da Silva (Miriam } \\
\text { Lindemberg) }\end{array}$ \\
\hline 23. Monica Moura Vieira Pardal & 24. Naira Neide Ciotti (Naira Ciotti) \\
\hline 25. Norberto Rafael Farias & 26. Numa Leme Junior (Numa) \\
\hline 27. Oswaldo Gonçalves Hernandez & 28. Raderley João M. Kovacvik (Raderley) \\
\hline
\end{tabular}


29. Roberto Klimas Banjoninas (RKB)

30. Rogério Carlos Gastaldo de Oliveira

31. Sonia Maria Lopes de Lima

32. Valdir Gomez (Gomez)

33. Walter Luiz Lopes de Miranda

(Walter Miranda) 
ANEXO G

OBRAS PREMIADAS "PERDIDAS" DOS SALÕES DE

ARTE CONTEMPORÂNEA DE SÃO CAETANO DO SUL

\begin{tabular}{|c|c|}
\hline \multicolumn{2}{|c|}{ I SALÃO } \\
\hline Artista & Obra \\
\hline Heinz Kühn & Reflexo III \\
\hline Ubirajara Molina Ribeiro & Robot \\
\hline Lourdes Cedran & Casa do pássaro flôr \\
\hline Mari Yoshimoto & Escultura X \\
\hline
\end{tabular}

\begin{tabular}{|c|c|}
\hline \multicolumn{2}{|c|}{ II SALÃO } \\
\hline Artista & Obra \\
\hline Aldir Mendes de Souza & Metropolização em plataformas II \\
\hline Leila Porto de Andrade & Caixa II \\
\hline Vera Ilce & Desenho I \\
\hline Vera Ilce & Desenho II \\
\hline Vera Ilce & Desenho III \\
\hline
\end{tabular}

\begin{tabular}{|c|c|}
\hline \multicolumn{2}{|c|}{ III SALÃo } \\
\hline Artista & Obra \\
\hline Antônio Vitor & Variação 1̃ de um tema patético \\
\hline Armando M. Sendin & Duas faces da moeda \\
\hline Dalton Salem Asseff & Corpos 3-4 \\
\hline Francisca Carolina do Val & Saída da aula \\
\hline Hanna Henriette Brandt & Meheler em vigília \\
\hline Juarez Magno de Freitas Almeida & Caixa II \\
\hline Leila Porto de Andrade & Vibração \\
\hline Lothar Charoux & \\
\hline
\end{tabular}




\begin{tabular}{|c|c|}
\hline \multicolumn{2}{|c|}{ IV SALÃO } \\
\hline Artista & Obra \\
\hline Eveline Borges & $\begin{array}{c}\text { Da festa de macucos nos matos do } \\
\text { brejo de abrolhos }\end{array}$ \\
\hline Gabriel Borba Filho & Nife III - escultura \\
\hline Hannah Henriette Brandt & Campos \\
\hline Iracy de Almeida Puccini & Pintura I \\
\hline Maria Olímpia Vassão & Inominável I \\
\hline Raphael da Costa & Inominável II \\
\hline Romildo Paiva & Bomem em formas a máquina I \\
\hline Sérgio Fingermann & Gravura III \\
\hline Sonia Von Brusky & Sibarismo diabólico \\
\hline
\end{tabular}

\begin{tabular}{|c|c|}
\hline \multicolumn{2}{|c|}{ V SALÃo } \\
\hline Artista & Obra \\
\hline \multirow{2}{*}{ Antônio Lizárraga } & Portátil/Notação \\
\cline { 2 - 2 } & Pural/Fonético \\
\cline { 2 - 2 } & Torques/Critérios \\
\hline Aracy R. M. Zanotti & Obsessão III \\
\hline Geraldo José de Souza - "geu" & Mercouri III \\
\hline Gerty Sarué & Série III \\
\hline Irene Satie Shoyama & Veduta III \\
\hline
\end{tabular}

\begin{tabular}{|c|c|}
\hline \multicolumn{2}{|c|}{ VI SALÃO } \\
\hline Artista & Obra \\
\hline Aracy R. Monteiro Zanotti & Tapeçaria - Grotas 5 \\
\hline Cesar Oscar a. Pellegrino & Desenho III \\
\hline Mario Marcos Tagnini & Tudo passa... \\
\hline
\end{tabular}




\begin{tabular}{|c|c|}
\hline \multicolumn{2}{|c|}{ VII SALÃO } \\
\hline Artista & Obra \\
\hline Eduardo Fontes Hotz & Paisagem natural (conservação?) \\
\hline Ilsa Leal Ferreira & Ritmo i \\
\hline Odair Magalhães & Ultrapassando... É agora \\
\hline Regis Machado Silva & Composição III \\
\hline Wilson Rodrigues de Moraes & A cerimônia secreta \\
\hline
\end{tabular}

\begin{tabular}{|c|c|}
\hline \multicolumn{2}{|c|}{ VIII SALÃO } \\
\hline Artista & Obra \\
\hline Hans S. Grudzinski & Ferradura - Rio \\
\hline Ilsa Leal Ferreira & Folhagem I \\
\hline Izar do Amaral Berlinck & Inverno \\
\hline Massuo Nakakubo & Serigrafia I \\
\hline Romildo Paiva & Condicionamento C \\
\hline
\end{tabular}

\begin{tabular}{|c|c|}
\hline \multicolumn{2}{|c|}{ IX SALÃO } \\
\hline Artista & Obra \\
\hline Décio Duarte Ambrósio & Proposta d. A. 2 (ou d. A. 3?) \\
\hline \multirow{2}{*}{ Evandro C. Jardim } & O coração de máquina frangente \\
\cline { 2 - 2 } & À tarde a sombra \\
\cline { 2 - 2 } & O sol sobre a cadeira \\
\hline
\end{tabular}

\begin{tabular}{|c|c|}
\hline \multicolumn{2}{|c|}{ XI SALÃO } \\
\hline Artista & Obra \\
\hline Numa Leme Junior (Numa) & Graffit City \\
\hline Valdir Gomez (Gomez) & Sem título \\
\hline
\end{tabular}




\begin{abstract}
ANEXO H
OBRAS NÃO PREMIADAS OU NÃO ACEITAS QUE CONSTAM NA COLEÇÃO DOS SALÕES DE ARTE CONTEMPORÂNEA DE SÃO CAETANO DO SUL
\end{abstract}

\begin{tabular}{|c|c|c|}
\hline \multicolumn{3}{|c|}{ I SALÃO } \\
\hline ARTISTA & OBRA & SITUAÇÃo \\
\hline Tecla Ivanova & Cavalo Branco & não premiada \\
\hline Hisao Shirai & Mitologia I & não premiada \\
\hline Kenichi Kaneco & Apocalipse A & não premiada \\
\hline Kenichi Kaneco & Apocalipse C & não premiada \\
\hline Algacyr da Rocha Ferreira & Nú & não aceita \\
\hline Kenichi Kaneco & Apocalipse B & não aceita \\
\hline Issao Shirai & Mitologia III & não aceita \\
\hline
\end{tabular}

\begin{tabular}{|c|c|c|}
\hline \multicolumn{3}{|c|}{ III SALÃO } \\
\hline \multirow{2}{*}{ ARTISTA } & OBRA & SITUAÇÃo \\
\hline \multirow{3}{*}{ Rubem Rey } & Cafonismo I & não premiada \\
\cline { 2 - 3 } & Cafonismo II & não premiada \\
\cline { 2 - 3 } & Kitch Paka I & não premiada \\
\cline { 2 - 3 } & Kitch Paka II & não premiada \\
\hline
\end{tabular}

\begin{tabular}{|c|c|c|}
\hline \multicolumn{3}{|c|}{ VIII SALÃO } \\
\hline ARTISTA & OBRA & SITUAÇÃo \\
\hline \multirow{2}{*}{ Ana Alice Francisquetti } & Amanhecer & não premiada \\
\cline { 2 - 3 } & Entardecer & não premiada \\
\hline Elenir de Oliveira Teixeira & Estouro da Boiada VI & não premiada \\
\hline
\end{tabular}




\begin{tabular}{|c|c|c|}
\hline \multicolumn{3}{|c|}{ XI SALÃO } \\
\hline ARTISTA & OBRA & SITUAÇÃO \\
\hline $\begin{array}{l}\text { José Roberto Cunha da Silva } \\
\text { (Robert Cunha) }\end{array}$ & Bandeira I & não premiada \\
\hline \multirow{3}{*}{$\begin{array}{c}\text { Jandira Chagas Martini (Jandira } \\
\text { Martini) }\end{array}$} & $\begin{array}{c}\text { Galáxias: as profecias- } \\
\text { cidades e planetas do futuro } \\
\text { em microcosmo Gamimedes I }\end{array}$ & não premiada \\
\hline & $\begin{array}{l}\text { Galáxias: as profecias- } \\
\text { cidades e planetas do futuro } \\
\text { em microcosmo Gamimedes II }\end{array}$ & não premiada \\
\hline & $\begin{array}{c}\text { Galáxias: as profecias- } \\
\text { cidades e planetas do futuro } \\
\text { em microcosmo Gamimedes } \\
\text { III }\end{array}$ & não premiada \\
\hline \multirow{2}{*}{$\begin{array}{c}\text { Claudia Rodrigues (Diá } \\
\text { Rodrigues) }\end{array}$} & Sem título i & não premiada \\
\hline & Sem título ii & não premiada \\
\hline \multirow{3}{*}{$\begin{array}{c}\text { Rogério Carlos Gastaldo de } \\
\text { Oliveira }\end{array}$} & Dimensão i & não premiada \\
\hline & Dimensão ii & não premiada \\
\hline & Dimensão iii & não premiada \\
\hline \multirow{3}{*}{ Raposeiro } & Apocalipse & não aceita \\
\hline & Sol & não aceita \\
\hline & Árvore & não aceita \\
\hline \multirow{3}{*}{ Carmem Zanchi } & Observação & não aceita \\
\hline & Feliz & não aceita \\
\hline & Interrogação & não aceita \\
\hline
\end{tabular}

